University of California, Hastings College of the Law UC Hastings Scholarship Repository

UC Hastings Faculty Books

1978

\title{
Hastings College of the Law: The First Century
}

Thomas Garden Barnes

Follow this and additional works at: http://repository.uchastings.edu/faculty_books

\section{Recommended Citation}

Barnes, Thomas Garden, "Hastings College of the Law: The First Century" (1978). UC Hastings Faculty Books. Book 1.

http://repository.uchastings.edu/faculty_books/1

This Book is brought to you for free and open access by UC Hastings Scholarship Repository. It has been accepted for inclusion in UC Hastings Faculty Books by an authorized administrator of UC Hastings Scholarship Repository. For more information, please contact marcusc@uchastings.edu. 

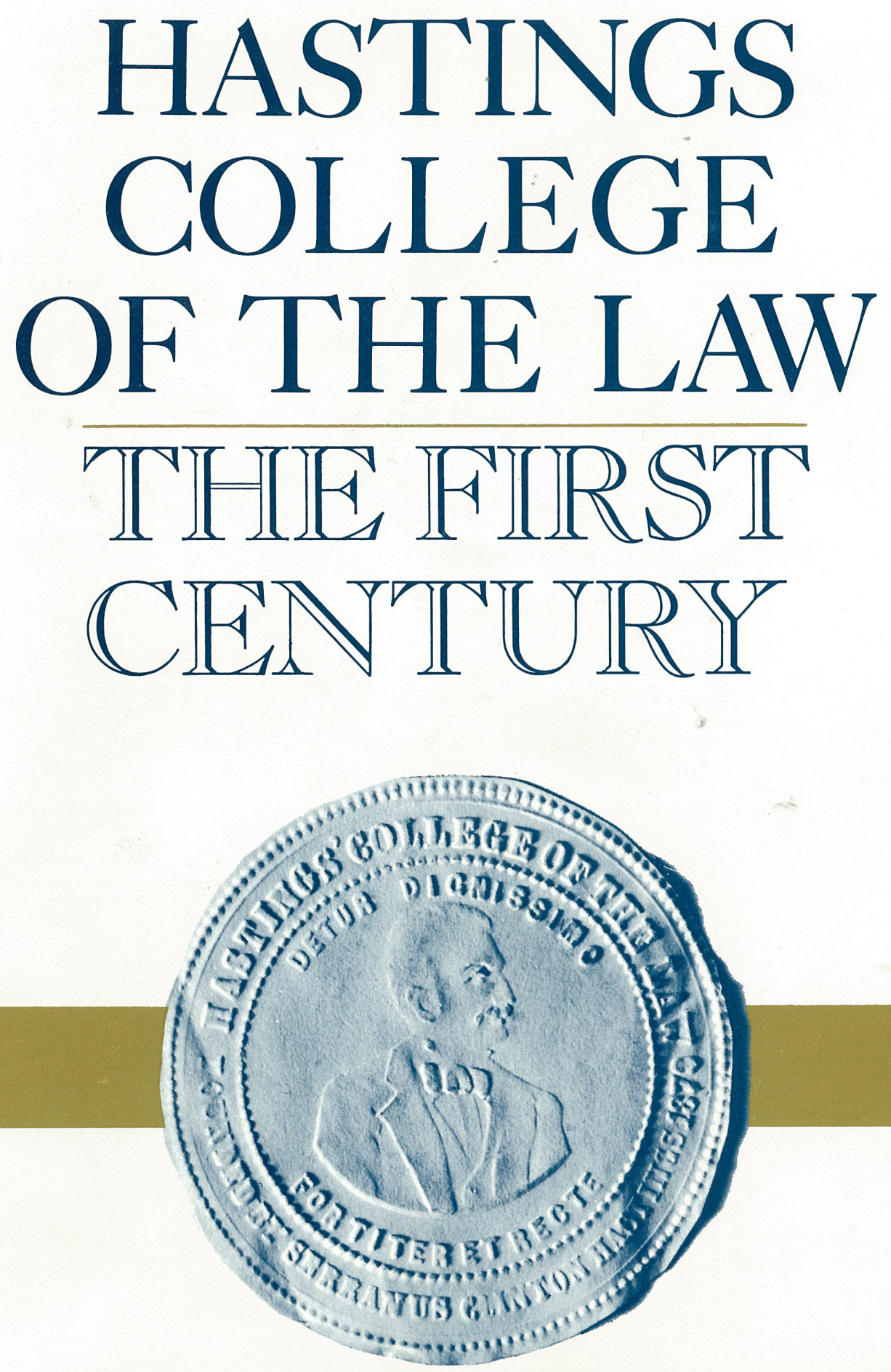

Thomas Garden Barnes 


\title{
Hastings COLLEGE OF THE LAW THE FIRST CENTURY
}

\author{
By Thomas Garden Barnes
}

\section{PREFACE}

\author{
University of California \\ Hastings College of the Law Press
}

Copyright (C) 1978

By the Board of Directors

Hastings College of the Law 


\section{Preface}

$\mathrm{T}$

HIS STUDY is the official Centennial History of Hastings College of the Law, which was commissioned by the Board of Directors in 1973. The faculty History and Arts Committee, under the chairmanship of the late George E. Osborne, discussed the nature of the project with me and invited me to undertake it. What the Committee wished was a full-length history of the first century of the College that would also make a contribution to the history of California and to that of legal education in the United States. This wish accorded entirely with my own idea of what I should do, because my principal scholarly interests have been in the history of institutions, either legal institutions or institutions closely connected with the law, in the context of political and social change, usually with a definite local focus. What made the task both stimulating and difficult was unfamiliarity with time and place, both far from my previous scholarly concentration. An historian of Tudor and Stuart legal history, who has felt very daring in making sorties into the legal history of early Massachusetts and French courts about 1600, I found it a new experience to work in "recent" history in the American Far West. This required the acquisition of a great deal more knowledge of American and California history than I would otherwise have attempted. I am left with a certain uneasiness about writing the history of an institution which is not only not defunct but very lively 
as it rushes into its second century. On reflection, after the fact, the work done, I have quieted my uneasiness with the recognition that there are certain similarities in the development of all institutions in any context irrespective of period. The narrative emphasis that a study such as this demands knows neither place nor time. Certainly, given the paucity of institutional archival material, my fears of being crushed by the burden of documentation with which my colleagues in recent American history must deal were chimerical-and the skills that the mediaevalist and early-modern historian must command to make the best use of what he has in documentation have stood me in good stead. At the time I agreed to write this history, I thought the History and Arts Committee was bold to confide this project to a scholar who has for a quarter of a century exhibited great reluctance to go beyond 1641 . No less courageous was the Committee's decision to commission a professor at Berkeley to do the job. Perhaps that my base is primarily the history department seemed reassuring, but that my secondary site is Boalt Hall should have caused some disquiet! I have striven to keep my Berkeley biases under control.

Though this study has been commissioned, it is not "court history," not an exercise in panegyrics. I was in no way connected with Hastings before I began work. Over the course of research and writing, which has occupied me for four years, I have maintained as much distance between myself and the College as I could and still obtain the assistance of the staff for the provision of materials for the research. While I gathered oral evidence in taped interviews, the bulk of my evidence is written. No documentation has been kept from me, no question that I have put has been answered otherwise than fully and honestly, no attempt has been made to impose a viewpoint on the work or its author. This history represents my own best interpretation made on the basis of the evidence. Not everyone will be pleased with 
all of it, but their displeasure can only be manifested after the fact.

Because I have not been connected with Hastings other than in this work, this history does not have that graceful intimacy and filial affection which Arthur Sutherland's recent history of Harvard Law School possesses. On the other hand, it is in some ways more ambitious than Sutherland's book, since I have sought to fit Hastings into its regional ambience and also to deal with some of the great issues of American legal education over the past century. This study does assume a certain familiarity with the general history of the United States and an awareness of California's past. Much of the broader context is at most alluded to; I resisted the impulse to write the history of California from the perspective of Hastings. On balance, I believe that Hastings has responded much more to professional and academic influences than to political and social forces. Yet I have avoided the heavily internalized approach that Elizabeth Gaspar Brown took in chronicling the University of Michigan Law School's first century. The glory of Hastings has been its people, who were also singular personalities, not limited to their intramural importance or a purely institutional prominence. Until the last quarter-century at least, Hastings was indeed almost entirely the shadow of its dean at the time. This is no longer true, but the possibility for an individual to make a perceptible and measurable impact on the institution by a single act remains greater at Hastings than in most educational institutions. That so much of the narrative (and therefore the history) centers on personalities is not a misplaced emphasis.

I confess that as I finish the race, I have come to have genuine affection for Hastings College of the Law. It is a seductive place, different, full of enthusiasms, buoyed by pride, lively, loved. But then, this is not to tell any of its faculty, staff, students, alumni, and friends anything they did not already know. This book is of- 
fered to them to tell them more about what they long ago appreciated.

Though the action of Indebitatus Assumpsit has long since passed out of our Common Law, I stand a seventeenth-century debtor to all those who have helped me without any express promise on my part to repay them for their labors!

One of the major rewards of my travail has been the opportunity to meet personally or to talk on the phone with many alumni, faculty, staff, students, and friends of Hastings. All responded with graciousness, enthusiasm, and infinite patience. Perhaps it is invidious to single out a few to receive thanks for all, but Thomas L. Berkley, A. Frank Bray, Jr., Albert G. Evans, Hazel Utz Lancaster, Lewis E. Lercara, Ben Margolis, and Wiley W. Manuel provided aid above the call of duty. Of the many who, though not technically alumni, have been connected with the College in one way or another, and have accorded me assistance, I wish to thank particularly Harry H. Hastings, Juanita M. Olsson, and Robert Gordon Sproul, Jr. The faculty of Hastings who have gone out of their way to be of help have placed me under special obligation. Jerome Hall, Thomas R. Kerr, Adrian Kragen, the late George E. Osborne, George S. Prugh, and Sheldon Tefft, all past or present members of the History and Arts Committee, proffered advice and encouragement much appreciated. The staff at Hastings assisted greatly in finding information and running to earth hard to find facts, and I am especially grateful to Jacqueline Bartells, Myrl Northway, and Elizabeth Stroube for their help in this. To all the College's "family," my most sincere thanks for their forebearance and assistance.

To a number of people outside the "family," I have incurred debts for a variety of courtesies. Lynn Otis provided her typescript guide to the State Archives' attorneys general documents. A number of librarians and 
archivists have been most helpful, but especially Robert H. Becker at the Bancroft Library, J.R.K. Kantor, the University Archivist, and at the Boalt Library, Francis Doyle and Thomas H. Reynolds. Saundra Epstein, who is engaged on a history of Boalt Hall, to be published next year, was unstinting in her assistance, and we have compared notes frequently. Gary Ostrower, whom I met at the Bancroft while he was engaged in research on the California women's suffrage movement, put me onto the Mary McHenry Keith papers and opened up for me that dimension of the College's impact. Three colleagues in History at Berkeley have rendered assistance, Gunther Barth and the late Walton Bean in Western and California history, and James H. Kettner in American legal history of the nineteenth century. My former student and old friend, Leo M. Snowiss in Political Science at UCLA, critically read the first two chapters. My colleague Preble Stolz at Boalt read and criticized Chapter VI, adding much to my understanding of the early law school reform movement. To all of these upon whom I could fix no Hastings claim and who are probably grateful that they will not again have to support me talking about the College, my most profound thanks.

There is a particular pleasure in thanking those directly engaged in the publication of this book, the first under the logo of the Hastings College of the Law Press. Jane-Ellen Long has undertaken production, engaging the exceptional talents of Randall Goodall as designer, and seeing the whole through the press. This has been a massive undertaking, with tight schedules made more snug by a procrastinating author, and she has done an efficient and devoted job. Adrienne Morgan ably executed the graphs and Karen Sussell the index. Martha A. Karatz, besides editing the College's alumni magazine, has served as editorial assistant, as retriever of rare photographs, lost data, and errant alumni, and as promotion editor. To my fellows on the Press' editorial committee-Marvin J. Anderson, David A. Concepción, 
Dan F. Henke, and Harriet Renaud-my heartfelt thanks and the temoinage of my happiness in having worked with them. Of course, to the Dean of Hastings College of the Law, the associate dean for administration, and the librarian (for Messrs. Anderson, Concepción, and Henke, respectively, wear those hats in more mundane moments) another debt of gratitude is owed, and not one to be easily discharged by mere acknowledgment. And so with Harriet Renaud, latterly the editor of this book but for many years neighbor and friend, to say thank you for an assiduous editing of the manuscript, constant availability to hash over crossed " $i$ "s and dotted " $t$ "s, and all this as galleys arrived while copy was still going to the compositor, is not enough. She saved the author from egregious error and the reader from much frustration. For the manifold help, the encouragement, and the fellowship in the enterprise of these colleagues, my gratitude and my homage.

To Jeanne-Marie, who knows as much about Hastings now as her husband does, to Claudine, Françoise, and Marc, who forewent the pleasurable frivolities that depend upon a dad and bore with the grumpy inattentiveness of father, my loving thanks for their tolerance, support, and encouragement of, and ineffable sensitivity to, an author possessed.

Berkeley, California

Thomas Garden Barnes

February 2, 1978

Candlemas 


\section{Prologue}

$\mathrm{I}_{\mathrm{N}}$ N THE history of our civilization, universities have been prominent both for what they have done and for merely being. As for what they have done, a perception of the university depends upon whether one is teacher or the taught. The university has been variously an avenue to place and power in Church and state by the vehicle of a sharp, narrow scholastic curriculum; an institutional structure within which an elite of status and property might be polished in gentility and adorned with letters; an academy for imparting a rigorous Classical learning that fit its votaries to any pursuit; and a school in which by the acquisition of credits in a range of subjects of varying academic merit a career could be forged. This is how those taught have seen it, and with good reason their perception has been primarily vocational and even careerist. To those who teach, the university is the keep in which man's painfully acquired knowledge, even his wisdom is guarded, undiminished, to be handed on through time, the bailey for the defense of free enquiry by which the sum of knowledge is advanced, and the guardroom in which the community of scholars, some of them active, some serving who only stand and wait, follow their science, and contribute to its increase and its diffusion. The imagery of the castle is not strained. Our universities were born in the castellated society of twelfth century Europe, and though the schoolmen were clerics and the collegiate structure, where it developed, closely resembled monasticism, the medieval university in its secular aspect was closer to the castle than 
to that other great monument of the age, the cathedral. The university was always under attack, imperilled by the barbarians without the walls, threatened by the urge to orthodoxy of ecclesiastical authority, in danger of subversion by the prince and his feudatories, and subjected to the bloody incursions of townspeople. The university's walls - of privileges and immunities reluctantly accorded by pope and prince, as well as by stone and mortar - were the defenses of a castle. And the university, unlike the cathedral, was not an oratory but a laboratory, a place not of prayer but of work, where neither the things of God nor of Caesar took precedence over the things of the mind, of reason and intellect. This has remained the role of the university-its function-in society from that day to this. No matter how "applied" the sciences taught and researched there, no matter how intimately involved with government, business, the professions, no matter how importunately students demand to be taught something useful, the university stands in a fiduciary responsibility to the corpus of knowledge gained from the past, conveyed in the present, and added to for the future.

The prominence of the university, by virtue of its mere existence, is a product of its venerableness and its uniqueness. Of all the institutions of modern society that survive from the middle ages, the university is the one that in form and function has changed the least. In government, with few exceptions, kings and barons have disappeared in the western world, and even where they have survived, aristocracy has given way to democracy. The Catholic Church of western Europe was halved by schism in the sixteenth century, and halved again by secularist disbelief in the centuries since, its works reduced to things of the spirit, its servants diminished in role and authority. Republicanism proved the victor over monarchy, secularism triumphed over the faith, but no ism has yet managed to destroy or even transform the university. The president and faculty of the poorest state university, harried by legislators and 
harassed by a suspicious and even antagonistic populace, still enjoy the privileged position of the rector and faculties of the medieval studium generale, still do the same things, maintain the same responsibilities. No western society has found a substitute for the university; indeed, it is a western institution that has become worldwide and has remained more vital than all other western institutions transplanted on the continents in the heyday of western imperialism. Something of the medieval jus ubi docendi, the right to teach everywhere, survives, and the university world of the intellect remains a community of scholars profoundly resistant to ideological tests and governmental and societal trammels on free enquiry and free teaching. The university is no less today than it was yesterday the ornament of culture, the factory of knowledge, the nursery of intellect, and the fount of the professions.

The earliest universities were the creation of late eleventh and early twelfth century scholars, of the physician Constantinus Africanus at Salerno, the lawyers Gratian and Irnerius at Bologna, the dialectician Abelard and the theologian Peter Lombard at Paris, and the lesser known masters at Oxford and Montpellier. Such spontaneous generation disappeared with the first creations. Thereafter, new universities were founded by the migration of scholars, civic enterprise, and the act of an individual or corporate founder, prince, prelate, or potentate, or a combination of all of these elements. For the scholars, it was the opportunity to gladly learn and gladly teach in a new and (apparently) more friendly environment. For the city, civic pride dictated the acquisition of a studium, and the bourgeoisie reasonably expected that trade would follow where arts, letters, and science had preceded. For the founder, the university manifested his greatness and generosity, attributes highly esteemed by medieval man both to advance his stature in this world and to improve his standing in the next. As one of the last medieval men to found an Oxford college put it in the preamble to the foundation 
statutes of Corpus Christi College (1517):

We have no abiding city here (as saith the apostle) but we seek one to come in heaven, at which we hope to arrive with the greater ease and despatch, if while we travel in this life, wretched and death-doomed as it is, we rear a ladder whereby we may gain a readier ascent. We give the name of virtue to the right side of the ladder, and that of knowledge to the left, and between these two sides lie steps; for either side hath rounds of its own, by which we may either soar on high, or sink into the lowest depths. ${ }^{1}$

Richard Fox, Bishop of Winchester and Lord Privy Seal to Henry VII and Henry VIII, expressed a time-honored sentiment in the motives for his beneficence. And to the initial generosity of the founder would be added over the years the munificence of others. Munificent patronage also set the university apart from most other institutions, the church excepted, and that is still true today, in the support that individuals-sons and daughters and friends of alma mater-foundations, and latterly the state accord it.

Whatever the range of motives that led to the foundation of universities and their continuing endowment through benefaction, behind each university that established itself and survived was a need. The sentiment of an age and of the society evoked the university. The degree of practicality of the need variedsome institutions have had a more "pure" and others a more "applied" function in the vision of their founders and benefactors. But behind all was need.

The two institutions which are the concern of this work, the university and the law, came to this culture on this continent at almost the same moment. In 1636 in Massachusetts, a college was established at Newtown, shortly to be renamed Cambridge in honor of the university from which most of those in the colony who had a university connection had come. It was not an afterthought, but a step taken because of a perceived need a short time after the edifying of Faith and the frame of government and law had been raised: 
After God had carried us safe to New England, and wee had builded our houses, provided necessaries for our liveli-hood, rear'd convenient places for Gods worship, and setled the Civill Government: One of the next things we longed for, and looked after was to advance Learning and perpetuate it to Posterity; ... .

It can be argued that Harvard College came into existence before the full elaboration of the rule-of-law came to Massachusetts. In 1641, an attempt was made to establish a fundamental law for the colony in the "Body of Liberties," but not until the gathering of the legislation of the colony in The Book of the General Lawes and Libertyes Concerning the Inhabitants of the Massachusets (1648), was the "Civill Government" fully settled insofar as it demands certainty in the law. ${ }^{3}$

It was a long time before the law found a place in the American university. The reasons were many and complex, but the more salient ones deserve mention. First of all, the law which was taught in European universities, including Oxford and Cambridge, was the highly academic law which had spawned Bologna: Roman Law, in its two facets, the Civil Law and Canon Law. By the thirteenth century, the Civil and Canon Laws had come to dominate all the universities, threatening the primacy of the Queen of Sciences, Theology. The Reformation in England expelled Canon Law from the two universities, but Civil Law remained, and served in one major secular court, Admiralty, and in the ecclesiastical courts. Not until the eighteenth century would the English common law receive any attention in the English universities, and it was not taught consistently until the mid-nineteenth century. The Vinerian professorship at Oxford, established in 1758, was the first chair in the common law in the English-speaking world. It is noteworthy that the second oldest American institution of higher learning, William and Mary in Virginia, established such a chair in 1779, and that the Royall professorship in common law was bequeathed by Isaac Royall to Harvard on his death in 1781 , although it was 
not filled until 1815. Both American institutions followed the lead of Oxford under the influence of the first Vinerian professor, Sir William Blackstone. Secondly, there was from the outset in the American colonies considerable mistrust of lawyers, more marked in the puritan colonies than in those to the south. As the early colleges did not seek to educate young men in the law, neither did any of the colonies encourage the creation of that peculiar institution which gave England its bar, the Inns of Court. The early evolution of the colonial bars grew out of the autodidacticism of self-styled "attorneys" (few of them with any formal legal training in England) and the apprentice method of law-office study that very soon came into existence. The first "law school," that of Judge Tapping Reeve in Litchfield, Connecticut, in the $1780 \mathrm{~s}$, began as an extension of his law office, but it grew rapidly, and between 1784 and 1833 trained over a thousand lawyers from all over the new country. Thirdly, the pattern of westward expansion in this country, beginning in colonial times but reaching the proportions of a general cultural phenomenon in the early national period, created a demand for lawyers that could not readily be met by available formal instructional means, and which in the opportunity society of the frontier no young man was really inclined to tarry for. Finally, in the first flowering of higher education in the national period, the new colleges springing up all over the United States right to the edge of the frontier, many of them sectarian institutions, adopted a heavily Classical curriculum. This Classicism emphasized the traditional liberal arts of humanistic learning, and by its apparent completeness and holistic adequacy persuaded one trained in it that he had all of the learning that was necessary, and that academe might impart, to undertake any profession. Classicism was not, as some of its critics have urged, antithetical to professionalism. In fact, Classicism assumed that all knowledge was part of an organic whole, was governed by the same natural rules, and that a rigorous grounding in the 
humanistic disciplines allowed the learned man to unlock any subject, follow any vocation, with no more to add than command of the formal peculiarities of the professional activity. In this view Classicism was the highest level of professional preparation obtainable. It would require a kind of enlightenment from a foreign source-the German universities-in the late nineteenth century to cast professionalism and therefore professional education in a new light.

In 1849 the frontier made a big jump, a thousand miles from the Missouri River to the foothills of the Sierra Nevada mountains, the land between abandoned to the Indians, to the trappers and traders still left, and to such hardy eccentrics as the Mormons. The piecemeal creeping tide of westward migration became a single great wave that left the flotsam of many cultures on the edge of the Pacific, the small indigenous Spanish-speaking culture being submerged under the wave. The new metropolis was San Francisco, the "instant city" of the first great transcontinental lunge. The new urbanites of the instant city:

lived in a culture so totally different from the ones they had left that often the transition was almost unbearable. Almost everything they created was made to serve the moment and most of their early work disappeared or fell into disuse when the moment passed. ${ }^{4}$

Massachusetts, two centuries later, was reborn again three thousand miles further west, without the homogeneity of the puritan forefathers of Boston. But like the old colony, the new sought in both the university and the law to cultivate the unifying power of the intellect, to bring order out of chaos, and to build something that would serve not only the moment but all time.

What had taken Massachusetts a bare six years took California twenty, but the University of California came into existence in 1868 full of promise, ambition, problems, and inadequacies. It would be another decade before California would have its first law school-and that would be the first west of the Missouri River. One man, 
who had played a distinctive, even determinative role in the coming of "the law" to California, also gave California its first academy for the formal training of lawyers and the University of California one of its earliest higher faculties and professional schools. Serranus Clinton Hastings stood in the tradition of the medieval founders of colleges and universities. The comparison to Bishop Fox is striking: a man of affairs, not an academic, in the service of the state, seeking to erect a ladder to heaven, with two sides, "virtue" and "knowledge." The need to be met was evident. The hope of encouraging other benefaction was high. Civic pride was appealed to - the new college would be sited in the instant city, a point of distinction for the new metropolis. It would be part of a great state university, but would enjoy a marked autonomy by virtue of having its own trustees, presided over by the highest servant of the law, the Chief Justice of California, a secular archbishop or the lord high chancellor, if you will. The new college was not for profit, its objectives were unsullied by base motives. Characteristically, from its conception, Hastings College of the Law was unlike any other American law school; indeed, not quite like any other institution of higher learning.

This is a history of that law school during its first century. Though it was the idea of a single man, it has been the work of many. It has reflected the greater influences washing against it from society outside it. Yet like the university throughout western civilization, Hastings marched to a different drumbeat than society's, that of the scientia which was its responsibility to preserve and to which it was to introduce Justitia's votaries. Through all its trials and tribulations, for all its changes, despite all its failures and its successes, Hastings never shut its ear to the drummer. In that it has fulfilled the vision of its Founder, the hopes of its professors, and the desires of its students. In the process, it has woven itself into the fabric of California, and contributed to 
California's phenomenal growth over the course of a century. As with every university that responds to a true need in its origins and continues to respond to changing needs, the history of Hastings College of the Law will know no end, only many beginnings. 


\section{Founding and Founder}

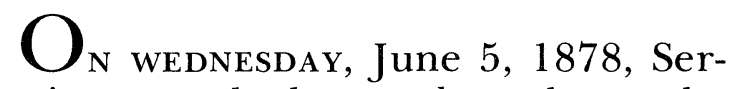
ranus Clinton Hastings was the honored speaker at the annual Commencement of the University of California, recently located in Berkeley. He was there to announce that he had completed the gift that would give to the University its "Department of Law" in the form of an affiliated institution, Hastings College of the Law. Dr. John LeConte, a soft-spoken Georgian, the President of the University and the first member of the University's faculty with his appointment to the chair of physics in 1868, was in the chair. Most of the Regents, including Governor William Irwin, were present. It being a fair day, the convocation was held under the oaks east of the still-standing South Hall (the last open-air commencement until 1901, the octagonal Harmon Gymnasium completed in 1879 being preferred to rustic simplicity despite the inevitable aura of perspiration only slightly lightened by the open louvres of the gym's cupola). Perforce, the gathering was small: the faculty numbered twenty-nine, not including the President and a halfdozen administrative officers, and the total student body for academic 1877-78 numbered 318 students, not many of whom save for the Class of 1878 were likely to have been present. Of those graduating, eight students were to receive the Bachelor of Philosophy degree in science, six the Ph.B. in letters, including two women, and fourteen the degree of Bachelor of Arts, one of 
them a woman. Families and friends of the graduates, faculty families, and a smattering of interested spectators would have completed the company. There was no "town" yet in Berkeley, only "gown," and Oakland was a one and one-quarter hour's horse-tram ride away. The decade-old university boasted six colleges in three buildings at Berkeley (Mechanical Arts, just completed, and North and South Halls, overlooking fields, the buildings in which the Class of ' 78 had followed a rigidly classical curriculum), a college of medicine, and an "affiliated" college of pharmacy, in San Franciscobut it was still primarily a small liberal arts college. There was about the convocation the intimacy of the few, made more pronounced by the slightly exaggerated dignity that Victorian solemnity held appropriate for such occasions. No mortarboards were thrown into the air by jubilant graduates, no placards of protest swayed above the heads of the spectators, and John LeConte, M.D., was not the ebullient, full-throated arm-waving Robert Gordon Sproul who would give a particular magic to three decades of later commencements. But with the presentation made by the Honorable Serranus Clinton Hastings, the University of California took another step towards the multiversity of our day.

For eight of the day's graduates, what Chief Justice Hastings said was to have more than merely academic interest. All shortly to become Hastings students, these were Lemuel Warren Cheney, from Chico, Ph.B. in mining, whose senior thesis, "A Method of Machine River-bed Working for Gold," was redolent of the past and still relevant to the present; Alexander Francis Morrison, A.B., of San Francisco, whose thesis, "Property in Land," clearly pointed to his future; William Martin Van Dyke, A.B., from East Oakland, whose thesis was "Means of Improving the Condition of the Laboring Classes," and whose oration, one of three given by student speakers, was on "Civil Liberty"; Joseph William Winans, A.B., of San Francisco, son of a 
Regent of the University, whose thesis extolled "The Advantages of a Classical Education" such as he had just received; Frank Randolph Whitcomb, A.B., of San Francisco, whose thesis on "Capital and Labor" may have raised an uncomfortable spectre or two for his readers; Joseph Hutchinson, another Ph.B. in mining, of San Francisco; William Raymond Daingerfield, A.B., of San Francisco, whose thesis dealt with a perennial issue about to become a burning one in post Reconstruction national politics, "Minorities and Majorities in Representative Bodies"; and Abram C. Bradford, Jr., Ph.B. in letters, of San Francisco.

Three years later, in 1881, Cheney, Morrison, Van Dyke, Winans, and Whitcomb were among the fortyfive students who received the College's first LL.B. degree. They entered Hastings in August 1878, as did Bradford and Daingerfield, neither of whom graduated, though Daingerfield managed after one year at the College to be admitted to the bar, ultimately joining an eminent firm (Morrison, his classmate, being another partner) in the City and attaining the superior court bench in 1892. Mining-engineer Hutchinson, who spoke at commencement in 1878 on "The Mission of Physical Science," followed that light for another year before entering Hastings in 1879 to graduate with the (second) Class of '82. Cheney took his first year at Hastings while a graduate student at Berkeley, ${ }^{1}$ took the LL.B. in 1881, and returned to live in Berkeley; Van Dyke went into practice in Los Angeles; Winans (who died young) and Whitcomb practiced in San Francisco, as did Hutchinson and Morrison. Morrison prospered; his widow, May T. Morrison (UC, '73) donated almost $\$ 2,500,000$ to Berkeley, giving the campus its present music building, her husband's library, and a handsome reading room in the General Library, and endowing chairs in Law (Boalt Hall) and History in their names-a munificence which did not, alas, extend to the institution that gave $\mathrm{Mr}$. Morrison the professional skills to make his fortune. 
It is possible that among the lower classmen present at commencement were two who became luminaries of that distinguished second, 1882, class at Hastings: Mary McHenry (A.B., UC, Classical course, '79) and Charles William Slack (Ph.B. in mechanics, '79). Mary McHenry was to become the first woman graduate of Hastings and one of the first rank of women suffragettes. Charles William Slack became more intimately involved with Hastings, over a longer period of time than anyone else in its history - as student, professor, dean, member of the Board of Directors, and Regent of the Universityfrom 1879 until his death in 1945. As a close friend of Daingerfield, having worked with him at Berkeley in the University printing office, Slack might well have stayed in Berkeley to see his friend graduate before returning home to San Francisco in June 1878.

Serranus Clinton Hastings began his address by saying, "Gentlemen, the Regents, President and Faculty of the University of California. I appear before you to announce the foundation and establishment of a College of Law in this University, which I will proceed to submit to you in detail." 2 Tall, dignified, blest with a good voice and piercing eyes, Hastings made a powerful impression. He was already a legendary figure. As a Member of Congress, 1846-48, from the newly admitted State of Iowa, he had rubbed shoulders with fellow Congressmen John Quincy Adams, Stephen A. Douglas, Andrew Johnson, and Abraham Lincoln. Chief justice of Iowa for only a year, he was a Forty-Niner, actively (and shrewdly) involved in the stirring events that led to the first California legislature and statehood, and led Hastings to the chief justiceship of the California Supreme Court in December 1849. That term up in 1851, he was elected attorney general for a two-year term, and began amassing the fortune that brought him added stature in the eyes of the generation of 1878 who knew Hastings more as a landed magnate than as lawyer and statesman. He was listened to.

The new "College of Law" that Hastings detailed 
was to be based on three cardinal considerations. First, that since the law was now largely "contained in modern codes and statutes," a student of the law could not become "imbued with the true spirit of jurisprudence" without studying the history of the law and its traditions. Second, that while California had many distinguished lawyers, "the general standing of the Bar is not perhaps as high as it ought to be" because law students did not receive the "training and mental discipline" essential to "the highest success and the greatest usefulness." Third, that the College was to "diffuse a knowledge of the great principles of jurisprudence" not only among aspiring practitioners, "but also among all classes of society, to elevate the standing of the Bar, and to maintain and perpetuate the purity and dignity of the Bench," without which "civilized government" cannot exist, and without which "the rights of property, life and liberty will vanish and become an exploded theory of the past, and communism, mobs and other disorders will prevail against law, order and good government." Hastings admitted that he did indeed seek to erect a monument, not "a house made with hands, but a temple of law and intellect which shall never perish, until in the lapse of time, civilization shall cease, and this fair portion of our country shall be destroyed or become a desert."

Hastings propounded definite views of how the law should be learned and what learning qualified a lawyer to practice. This disquisition (which warrants further analysis later) was founded on a range of historical allusions from antique Greece to Continental Europe and the great British universities (English, Scottish, and Irish). What he sought is clear, since the "most eminent nations in civilization supply the greatest number of that class of persons known under the generic term of lawyers." England, America, and at least republican Rome came out with high marks; the Russia of Peter the Great failed the Hastings criteria. "Barbarous and halfcivilized nations have but little use for these interpreters 
of the law or rules of civilized life. They repel their presence, and treat them with contumely and oppression." What Hastings desired was a student trained in a "system of close subjective thinking," wherein "metaphysics of the law" produce a lawyer who "by a cultivated instinct and apparent inspiration" can take "complicated facts for which there are no exact precedents or formula" and tell his client what the law is.

He prefaced the description of the structure of the College by a demurrer, even a disabling speech, that would prove all too prophetic. Pointing out that his plan was the result of many years' investigation, he said,

I have no right to expect that my views will be sanctioned by that body of learned men into whose hands I now consign this college [the Board of Directors]. They and their successors are to govern it in all time, and will be responsible for its success.... If it should so be, that these views meet the approval of the directors named in the statute, I shall be pleased. If they do not, I shall submit cheerfully to their better judgment.

In the event, the Founder's views on the educational program of the College did not meet with the Board's approval. Neither did he cheerfully submit to their better judgment. But no one, not Hastings, not the Board members present, certainly not the auditory, on that euphoric summer afternoon in Berkeley could foresee the chasm that would open between Founder and trustees, a chasm so wide that it almost swallowed the College.

With that precision and eye for specifics characteristic of him, Hastings detailed the structure of the College and the functions and responsibilities of its personnel. Despite the shade of live oaks, the day was warm and the three student orators had made the most use of their opportunity; a stifled, discreet yawn or two could not have been avoided as Hastings construed the founding act, recited the names of the Board members, and set forth the duties of Dean, Registrar, the one Professor of Municipal Law, and even a student Proctor. The evocation of the name of the Rev. William H. Platt, 
D.D., rector of Grace Episcopal Church, San Francisco, who had consented to lecture on "ethics and rules of morality," signalled the Founder's determination to inculcate in the College's students a high moral calling, but might have induced some to add to Hastings' description of Dr. Platt as one, "celebrated for his eloquence, science and religion," that he was also longwinded. Still, the ideal was novel-the ethical dimension of the law received no formal provision in contemporary law instruction, either in law schools or in law-office preparation for the bar. The Founder's intention of having a chair in physiology and medical jurisprudence was somewhat more electrifying, this being a field of science which was becoming prominent and possessed much appeal to contemporaries, both lawyers and doctors as well as the public. But what was most arresting in this dry, detailed presentation was Hastings' announcement that the College would have a three-year program. This would not only establish the new "Law Department of the University of California" as the first law school west of Des Moines, but it would be one of only three law schools-the others were Boston University (1872) and Harvard (1876) - to require more than two years for the LL.B. In 1878 this alone was almost revolutionary; that the third year would be devoted to study of "the codes and practice" was unique.

Certain poignant notes were struck in Serranus Clinton Hastings' address. Clearly, he intended that the College should be located in Berkeley, and that the "hall at San Francisco shall be auxiliary thereto as a part of the said college...." In fact, the room or hall for the College at Berkeley specified by the founding act and mentioned by the Founder was never provided, and from that day to this Hastings College of the Law has never had a Berkeley site. In greatest part this was because the act specified access to the San Francisco Law Library for the College's students as the principal resource for their legal studies. The Founder in his address might well allude to that library as the "equal to any library of the kind in the United States," but it soon 
proved inadequate to the academic purposes of a major law school. Also, though Hastings clearly meant that the College should be a "post-graduate college of the University of California" and that "great care shall be observed that no person shall enter as a student who shall be unworthy of a college of the eminent position it assumes," only 19 percent of that first class enrolled in August 1878 were graduates, and the College was to be plagued for a long time by insufficient academic standards for admission. On this score, however, the Founder himself showed some ambivalence in his declaratory address, admitting that "non-graduates must understand that a limited knowledge, especially of the Latin language, will be required," and even that some would be admitted for the second or even the third year of study on the basis of "examination of applicants for advanced standing." Poignant-but pernicious-was the Founder's suggestion that students be matriculated from anywhere in the state (which was not an objectionable notion) and be permitted to "pursue their studies where they reside" (which was). The extramural university, on the English model of London University's external degree, was something of a fad in the late nineteenth century, but it depended upon a narrow curriculum based upon a sound schooling, which did not exist in California in the 1880s, and it could not be applicable to study of the law on the new basis that was about to emerge, the "case method." Fortunately, nothing came of this suggestion. Yet the best quality of the university-without-walls was captured in the Founder's vehement opposition to "the rejection of any applicant or student on account of his poverty or limited means of support, as a calamity subversive of the object of the foundation." The College was to be open to all who would learn the law, to "supply a substitute for the Inns of Court, the historic Inner Temple, a temple of the law, which shall extend its arms and draw within its portals all who shall be worthy to worship at its shrine, resulting in the coronation of its votaries, as a reward 


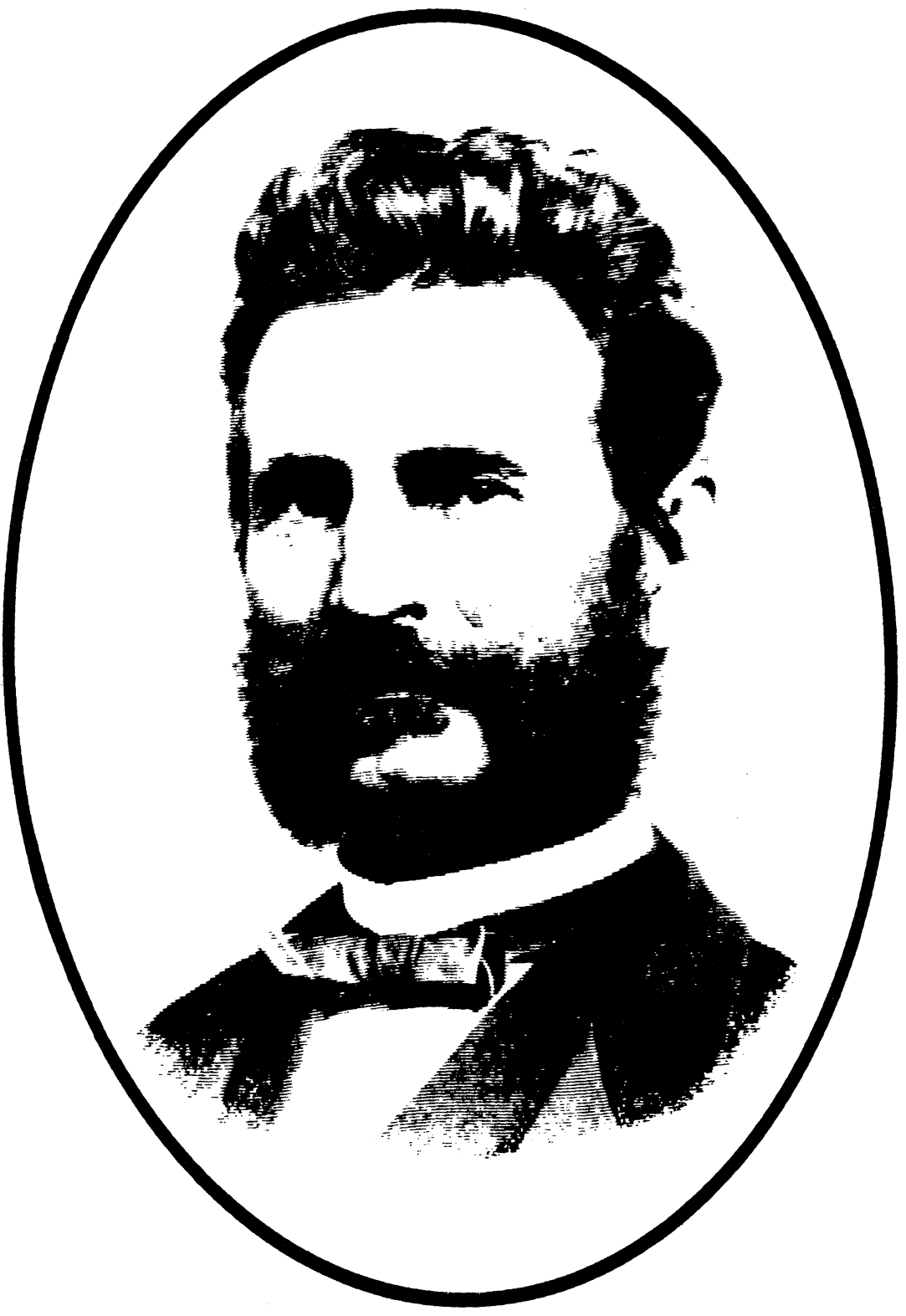

Serranus Clinton Hastings, c. 1850 

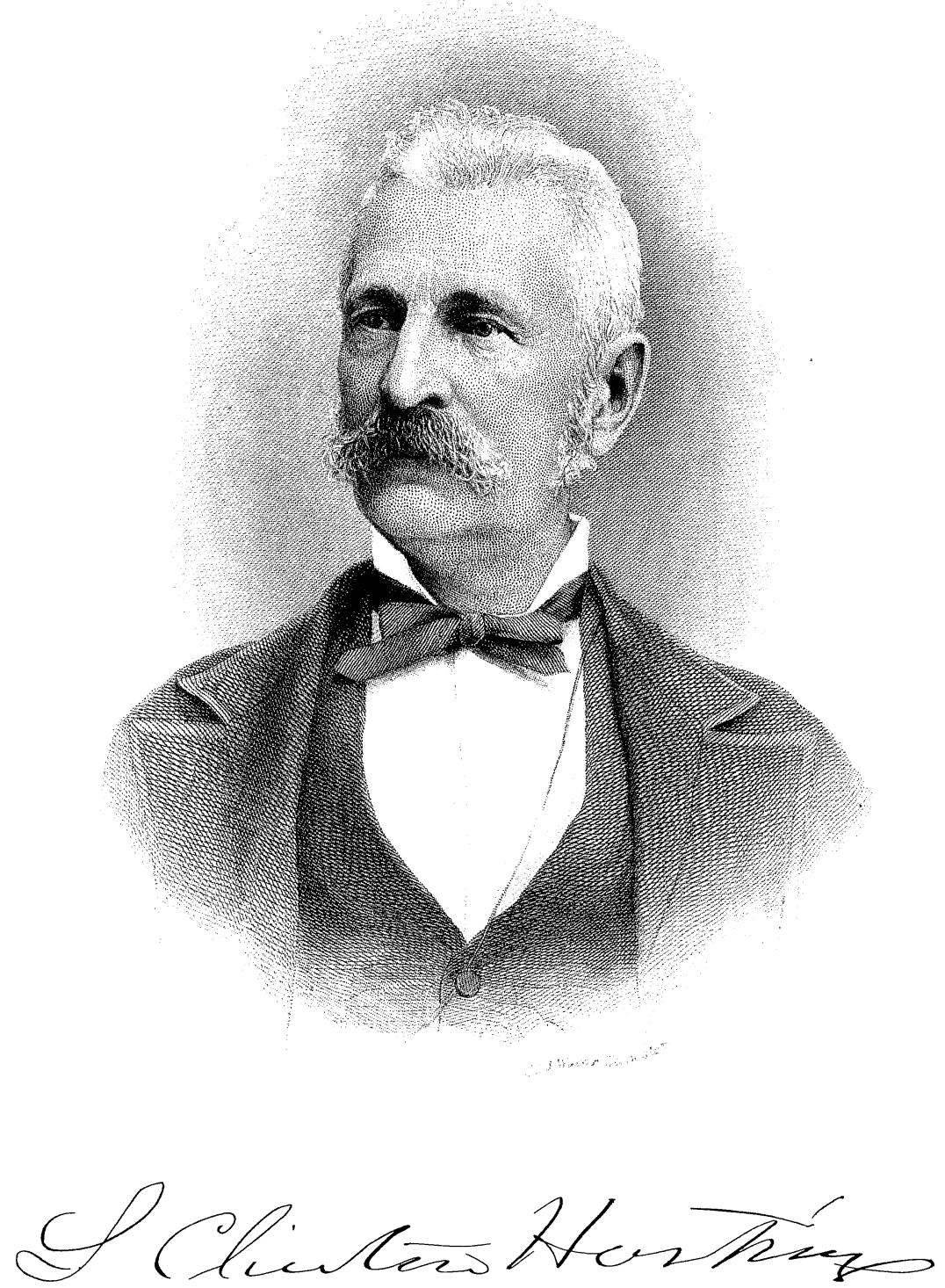

Serranus Clinton Hastings, c. 1880 
for application, industry and merit." On that note Chief Justice Hastings ended his address.

Thomas B. Bishop, Esq., prominent in the San Francisco Bar Association and one of the most highly respected lawyers in the state in the last quarter of the nineteenth century, rose to receive from Hastings' hands "this munificent gift to the present and to posterity." 3 Bishop acted in his capacity as one of the Directors of the new college. His speech of panegyrics and platitudes was painful, but mercifully short; his rhetoric was flowery even for that day. Though his remarks contributed nothing further in elucidation of the College's purpose, he was destined to play a major role in the early years of the College's development. Bishop was followed (for the day's last speech), by the Hon. Joseph B. Crockett, former justice of the California Supreme Court. Remarkable parallels, of age, career, time in California, and wealth tied Crockett and Hastings in a close bond of friendship. Justice Crockett was a wealthy landowner on San Pablo Bay in Contra Costa county around the town named for him in 1867. Like the Founder, he was a legendary figure, one of the pioneers of the New California. Alone among the speakers of the day, he evoked the awesome spectacle of how far California had come in a few decades:

When a literary institution like this [the University] is but commencing its career, in the midst of a new community, which, thirty years ago, consisted of only a few widely scattered hamlets, and a small number of rude rancheros, it encourages us to hope for the most magnificent results in the future. ... It also encourages the hope, that stimulated by the noble example of Judge Hastings, many other gentlemen of wealth will ere long conclude that the wisest disposition they can make of a portion of the abundant means which our Golden State has bestowed upon them with so lavish a hand, will be to endow liberally this great institution of learning, which, we hope, is destined to dispense its blessings to future generations....

Crockett would not let the audience forget how recent were the landmarks of its civilization, how young the 
"instant city" which was San Francisco, the "instant society" which was California. He enunciated, more clearly than had Hastings, the civilizing mission of Hastings College of the Law. Their generation had taken and built, cleared and sown, spun a web of trade, met and managed successive waves of immigrants, and succeeded in bringing order to a rootless, restless, and burgeoning metropolis and its environs as far as the borders of Oregon, Nevada, Arizona Territory, and Mexico. Crockett clearly saw that to the next generation would fall the task of civilizing what had now been ordered. Some measure of how rapid had been the work of ordering is suggested in the allusions of both Hastings and Crockett to the subversive forces at work "throughout a great portion of the civilized world, which seriously threaten, not only the peace and good order of society, but the stability and safety of all well ordered governments." ${ }^{5}$ Within thirty years of rustic primitiveness, of "rude rancheros," they could now afford the luxury of a shudder at the enemies, real and supposed, of the modern, capitalist, industrial society: Marx had taken the place of Murrieta as the threat to order and government in California! There could be but "one remedy for this grievance; and that is to be found in the better education of the masses of the people, and in wise laws, justly and temperately, but firmly administered."6 Crockett's vision, rooted in the sense that the past was past, was of "the noble mission of the Hastings Law School, under the fostering care of this University, to furnish to the younger members of the profession, and to those preparing to enter upon it, the best opportunity to become thoroughly instructed in the learning of the law, and at the same time to imbue them with those principles of morality, and with that nice sense of professional honor, which should be the crowning grace of every lawyer." Justice Crockett ended with the "confident prediction, that the Hastings Law School will speedily become a grand success, and will add another wreath to the chaplet which is to crown the 
University of California." The prediction was justly founded in the event, on both counts.

The Berkeley Commencement announcement was, of course, symbolic and formal rather than effectual and formative. The foundation of Hastings College of the Law was effected by "An Act to create Hastings' College of the Law, in the University of the State of California," Statutes, 22nd. Session, Chap. 351, signed into law by Governor William Irwin on March 26, 1878, and the subsequent fulfillment of the terms of his responsibility under the act by Serranus Clinton Hastings' payment of $\$ 100,000$ in U.S. gold coin to the Treasurer of the State in three payments- $\$ 60,000$ on April 18, $\$ 30,000$ on May 20 , and $\$ 10,000$ on May $27 .{ }^{7}$ With the Founder's last payment, the condition specified in Sect. 8 of the act was met just ten days before the Berkeley announcement. Though by Sect. 15 of the act, the act was to take effect from and after its passage, that is, March 26, Hastings College of the Law might as well date from the state controller's acquittance to the Founder on May 27. The Berkeley announcement was triumphal, the first public occasion possible to greet the new College. And symbolic contrivances have a way of being as real as reality. The Berkeley announcement had great press coverage, and the speeches of Hastings, Bishop, and Crockett were printed in extenso in a booklet. Indeed, the first meeting of the Board of Directors of the new College took place the day after the Berkeley Commencement, June 6, in the rooms of the San Francisco Bar Association. With that meeting, the College was well and truly launched.

Not everyone greeted the Berkeley announcement with the encomiums of the City's editorial writers and the enthusiasm that was manifested at the Commencement. Later in the summer one Charles Edward Pickett addressed ten foolscap folios to the Regents, President, and Faculty of the University, with a postscript to the first students at Hastings, and a request that the Secretary of the Regents transcribe the letter and send it to 
Serranus Clinton Hastings. ${ }^{8}$ Referring directly to Hastings' address at Berkeley, the redoubtable Pickett (showing a temerity equal to that of his cousin who had led the Army of Virginia to slaughter at Gettysburg) accused the Founder of having sold his decisions as Chief Justice, of having rendered purely political opinions as Attorney General, of having since been "the head of that villainous squad of 'leading lawyers' in California, known as 'Supreme Court Brokers,' " of being part of "The California Ring" of title-manufacturers and railroad robber-magnates, and of having with others bribed the Supreme Court to find valid their title to the San Francisco "Pueblo Lands," thus destroying Pickett's title to two lots on Rincon Hill. Virtually no member of the judiciary escaped Pickett's grapeshot, and Crockett, "that old knave and hypocrite," received a broadside. Pickett was sure that Hastings had endowed the College only to offset his crimes and so to secure credit with the Almighty_or had been compelled to it by his "Father Confessor (he is a Roman Catholic) when informed of a portion of these crimes." In all, bench and bar, and Serranus Clinton Hastings in the van with the business interests which Pickett castigated in a string of venomous pamphlets as the "Plundercrats," were those who polluted the fountains of justice to aggregate the wealth of the land into their hands, and then affected a dread of communism! He demanded that Hastings make restitution of the Pueblo Lands taken, "and if he shall refuse to make the restitutions demanded, especially the one to me, then ... this original letter shall be archived in that 'Monument,' at Berkeley, he has erected to perpetuate his memory, that its students, as long as it shall stand, may be informed what manner of man its founder was. ..." The letter is "archived"-so much Pickett accomplished.

Who was the attacker of Serranus Clinton Hastings (and virtually everyone else of wealth and influence)? "Philosopher" Pickett (he so signed himself) was indeed a cousin of General Pickett, and a genuine eccentric of 
early California, of less dross than "Emperor" Norton, and a man of always unpopular, usually unsound, but fearlessly advanced ideas. He migrated from Virginia in 1842, aged twenty-two, to the Willamette Valley, Oregon, and found his true vocation in publishing a biting weekly in hot pursuit of the new territory's magnates. In 1846 he set off for Virginia via California-and arrived in July at Yerba Buena just in time to witness Captain Montgomery raising the American flag on the shore near the U.S.S. Portsmouth. His role in the Bear Flag Revolt was principally that of stabbing at the U.S. military establishment's questionable competency and considerable cupidity, and the hero Frémont felt his lash. There was no silencing him, and he gave edge to the first English-language paper in San Francisco, the Star. Having been judge of Clackamas County, Oregon, though without a scintilla of legal training, he tried unsuccessfully to practice as an attorney in Yerba Buena (soon to be San Francisco) under the American alcalde. He was more successful in journalism than in any of the myriad other metiers he tried in the ensuing years. However, with increasing frequency editors closed their columns to him; he was too hot to handle. He was forced to become a pamphleteer, and without any restraining editorial influence the stream of political penny-dreadfuls that left his pen became increasingly strident and scurrilous. But he was after fair game. He saw monopoly and exploitation, the acquisition of enormous wealth, "plunder" by the big interests. His populism was ahead of its time. Despite his detestation of lawyers, he relied upon the sympathy of more than one San Francisco advocate to give him a corner to write in. He fought strenuously for redistribution of land (maximum lots of 160 acres to actual occupants only), state ownership of communications, city ownership of utilities, and tax reform (albeit he eschewed Henry George's single-tax as too radical). And he kept up his quest for "personal justice" in the form of claiming the property he had received under American alcalde grant 
in Yerba Buena on Rincon Hill. It was this claim that spawned his hatred of Hastings, for Hastings with others had acquired possession of the holdings of the numerous alcalde grantees. City ordinance, legislative enactments, decisions of state and Federal District courts, and act of Congress tolled the "Philosopher's" entry. His bitterness knew no bounds. His spirit never flagged. In 1874, he unilaterally attempted to enforce his interpretation of the 1849 Constitution's provisions for the term of State Supreme Court justices by attending the opening of the court and deliberately sitting in the seat of none other than Justice Joseph B. Crockett on the grounds that Crockett's term had expired. Pickett was fined and imprisoned on the spot for two contempts in the face of the court, and spent fourteen months in the county jail because he could not pay the $\$ 1000$ in fines. ${ }^{9}$ Pickett's case excited enormous popular sympathy for a character held in a certain affectionate regard by everyone save his well-placed and rich victims. The case, and the man, played a role in the passage of the new California Constitution of 1879, which settled the ambiguity as to the justices' tenure and otherwise worked some necessary judicial reforms, albeit they did not go far enough to suit the "Philosopher." Pickett, a porcupine with every quill a grievance, died attended by a widow-innkeeper at Mariposa in November 1880 , lowered into the grave to a recitation of Byron's "Inscription on the Monument of a Newfoundland Dog." That cynical and misanthropic poem was Pickett's final quill thrown, literally, from the grave.

Was Serranus Clinton Hastings a "Plundercrat"? The charges of selling justice, taking bribes, and other malfeasance in office can be dismissed easily enough. There is no evidence to support them, and Hastings was politically prominent enough to have had detractors who would not have hesitated to reveal particulars of any plausibly-founded charges of corruption. Historians, following the contemporary sense of outrage, have long accepted the last three decades of the nineteenth century as being the most venal in America's 
political annals. "Boss" Tweed, robber barons, the great financiers who bought governor, legislature, and courts in New York, the railroad magnates of the West swallowing whole territories and states-constituted a cast of hundreds perverting the politics of millions. California knew plenty of venality. But public opinion in California was less censorious than was opinion back East of the politician who took pains to prosper and protect his interests just short of real venality. California remained an "opportunity" society, enabled to grow more golden by the general economic development of the era and the possession of vast quantities of still unsettled lands. Every new Californian-the Chinese only exceptedhad a realistic hope of a lifetime's labor yielding prosperity and status. The Gold Rush was over, but the "boomtown" mentality of the Sierra foothills lasted a generation after the boomtowns became ghost towns. Only a few nuts, particularly failures-in fine, Philosopher Pickett types-could be expected to complain if political power brought wealth. In contemporary opinion, Serranus Clinton Hastings was accounted a most honest and upright gentleman, untouched by breath of scandal, personal or public, honored for his role in bringing law and order to Gold Rush California, and one upon whom the Golden State had indeed bestowed abundant means with so lavish a hand because he deserved the success brought by his own capacities, efforts, and assiduity. Philosopher Pickett might see the endowment of Hastings College of the Law as the Founder's fire-escape out of Hell, but Serranus Clinton Hastings was just one of a number of newly-rich philanthropists from coast to coast who would, to general acclaim, devote part of their fortuitous fortunes to good works. In fact, Serranus Clinton Hastings was one of the earliest such philanthropists.

Yet Serranus Clinton Hastings was very rich, and very newly-rich. He certainly was, by Pickett's reckoning, a "land monopolist." His fortune can only be estimated; it cannot be determined with exactness. How it was acquired is plain. Born in Jefferson County, New 
York, in 1814, he was the scion of an old Rhode Island family; his father had been a prominent commander in the War of 1812. A sound Classical education at Gouverneur Academy in New York prepared him for a modest and very academic profession. At the age of twenty, he became headmaster or principal of the Norwich Academy, Chenango County, between Utica and Binghampton, in upstate New York. He was there only a few months, but during that period he begain reading law with a local attorney. In 1834 he moved to Indiana, and in Lawrenceville completed his law studies with Daniel S. Major, Esq., being called to the Indiana bar in 1836. He had begun his westward odyssey, but he had not yet begun to make a fortune. In January 1837 he moved to the far frontier, the Black Hawk Purchase, now Iowa, then part of Wisconsin Territory. The set of his entire career was determined in the year he arrived, when he was appointed justice of the peace of the territory's strip along the Mississippi between Davenport and Burlington. He entered politics via the judiciary, began legal practice, and began to acquire land. He became a lifelong Democrat at the right time-the Party's fortunes were at their peak in the pre-Civil War period. Elected to the first Iowa Territorial legislature, he served for eight years (one session as president of the upper house) until his election to the 29th Congress in 1846 as a member of the first Iowa contingent. Hastings was a prominent advocate in the Iowa Territorial courts. Married in 1845, a political and financial success, his appointment in 1848 as the first chief justice of the Iowa State Supreme Court seemed a crowning glory for a man thirty-four years old. Hastings was, though, always the activist, restless and adventurous. His first term on the Iowa bench completed, he set out in a wagontrain for California in the spring of 1849 , leaving wife and children in Iowa.

Sired by a grub-stake brought with him from Iowa, Hastings' California fortune was born in Sacramento within a month or two of his arrival. His first act on 
reaching the Great Valley was to make an extensive trip into the gold country and to the coast to survey the prospects for future economic growth. He made the initial mistake of entertaining serious doubts as to the new land's agricultural potential, a misconception he soon remedied. By breeding, education, and shrewdness he felt his place was not at Coloma, Hangtown, or Woods Dry Diggins, but at Colonel Sutter's fort. Simultaneously, he opened a law office and a banking house, and could brag that in the first three days he had taken in $\$ 20,000$ on deposit. He lent out money at 10 percent interest per month - and found no want of takers. Attaining instant eminence in practice as prosecuting attorney of the Court of First Instance, it was natural that only a few months after his arrival, in December 1849, the newly convened not-quite-yet-state legislature selected him as the first chief justice of the California Supreme Court. The appointment, which he took up with alacrity and commitment, was a mixed blessing. He could do good, but he could not do well-as justice he was barred from private practice. The evidence indicates that when he left the bench in 1851 he was in "very straitened circumstances." ${ }^{10}$ His salary of $\$ 10,000$ a year was a pittance compared to the opportunities available in practice.

Having completed the term specified by the legislature as chief justice, Hastings ran for attorney general in the fall of 1851, and without much campaigning trounced his golden-voiced Whig opponent. There was no barrier to the attorney general undertaking private practice, and it was during those two years in office, 1852 to 1854 , that Hastings recouped the losses of the previous two years and built up a clientele that stayed with him throughout his short career in practice. He went into serious banking on the side in partnership in Sacramento, and even the failure of the bank left Hastings relatively unscathed. He had begun to "diversify" his interests. He continued practice for only a few years after leaving the attorney generalship, but the income 
gained increased his stock for investment, much of it in the form of sound loans on low interest terms, much in property. He lived modestly. His detestation of architectural magnificence, a recurrent theme in his exhortations to those connected with his College, was reflected throughout his life in his own unluxurious personal accommodations. In 1851 he brought his family to California, to a simple house in the new (shortlived) state capital, Benicia. His subsequent residences in the Napa Valley, including the vineyard house at Rutherford, were not the stately homes affected by contemporary nouveaux riches. Though most of his California career was centered in San Francisco, he was not the builder of a Nob Hill palace. All available money he put into real estate, and as soon as he established permanent residence for himself and his family in California, he sold off his Iowa holdings to invest in California property.

Hastings was a major purchaser of San Francisco land (which brought Pickett's wrath down upon him). The hazards were considerable: the unclear title to Pueblo Lands was a constant threat to quiet possession. Hastings was very much aware of the nature of the problem. The first of a long string of leading cases on the matter came before his supreme court in December 1850. In Woodworth v. Fulton et al. ${ }^{11}$ he entered a dissent in favor of the respondent primarily on the grounds that the law applicable to the respondent's claim by an American alcalde's grant was the law in effect at the time-Mexican law-and that he had a better claim to possession. It was for this opinion that Pickett, in his diatribe to the University, castigated Hastings' opinion as being for the "Ring" and against law and evidence, though on the face of the case, Hastings' position was reasonable and very much in line with his emphasis upon applying Mexican law, where not otherwise excluded by positive law, to the interregnum days between Bear Flag Republic and statehood. Incidentally, there is no evidence that the chief justice had any interest in the San Francisco lands at the time Woodworth v. Fulton et al. 
came before the supreme court. Hastings was not alone in fishing in these troubled waters, but he did it subsequently and by purchase of interests, some of which failed for want of adequate title and some of which succeeded. Interests were so confused, so many of them held conjointly, that partition was a necessity and always a peril. That Hastings did well in San Francisco property is attested to by the almost one hundred parcels of city property that he ultimately acquired. In 1887 the city property still in his name was valued at $\$ 150,000$; about a decade earlier he had conveyed inter vivos to his son, C.F. Dio Hastings, in trust for all his children, city property assessed at about $\$ 500,000$.

The bulk of Hastings' wealth was in the form of country property. This was realty that in all instances had good agricultural potential of one form or another, altogether very diversified agriculturally. All of his rural property appears to have been in five counties to the north of San Francisco: Sacramento, Solano, Napa, Lake, and Mendocino. We have no details about the agricultural use to which the Sacramento property was put. The Solano holdings were grain farms and cattle runs; Hastings Island near Montezuma Slough in the Delta preserves the connection. To his two eldest sons, in the settlement of the 1870s, he conveyed a fullystocked farm in Solano county. His extensive holdings in Napa county, including his demesne-residence at Rutherford, comprised three large estates mostly given over to choice vineyards. His Lake county property was principally cattle-grazing country, but he did maintain a summer home there. One of his single largest parcels was the Yokayo Rancheria, some 35,552 acres of prime grazing land in the Ukiah Valley along the Russian River. ${ }^{12}$ This land, the ancestral home of the YokaiaPomo Indians, Hastings bought at a sheriff's sale in 1859. Title was very confused, having been in one Cayetano Juarez by an 1846 Mexican gubernatorial grant. Hastings' friend, John Currey (also formerly on the supreme court), had a claim by deed from Juarez, but so 
too did General Vallejo. Hastings, Currey, and another claimant, H.W. Carpentier of Oakland, managed to acquire all interests by purchase, including that of Juarez, whose title was confirmed by Presidential patent in 1867. Hastings and Currey were the rated taxpayers for the property in 1864-65, when the value of the land was assessed at $\$ 35,552$ - or $\$ 1.00$ per acre-plus $\$ 8363$ in buildings. Even before Hastings, Currey, and Carpentier were confirmed in title, the valley was being opened for settlement. The second wave of immigrants had arrived, not for gold, but for soil. Hastings, Currey, and Carpentier agreed to divest to present occupiers-not at $\$ 1.00$ per acre, but on an average of $\$ 2.50$ per acre. The true value of the holding was, then, close to $\$ 90,000$. By such astute purchasing and selling of realty, Hastings managed to make his fortune. In 1862 he was worth about $\$ 900,000$; twenty years later, his fortune stood at $\$ 2,500,000$. Appreciation of land values had been the single largest contributor to his phenomenal prosperity.

"Philosopher" Pickett notwithstanding, Hastings can at best be damned for his success, not really for the manner in which he achieved it. The smattering of papers that remain from his days as attorney general clearly show that Serranus Clinton Hastings was a traditional lawyer with a traditional lawyer's notion of the preeminence of property. ${ }^{13}$ In his 1853 report to the governor, he deemed it his "duty to suggest a few amendments to the laws regulating practice in Civil and Criminal Cases; observing that experience admonishes that in these laws there should be as little alteration as possible." Certainly, he recommended then that the act of May 3, 1852, for the disposal of half-a-million acres of public land should be amended to speed up disposition of the lands, and that the clause of the law which prevented any one person from purchasing land warrants for more than 640 acres should be repealed as being inconsistent with the clause which made the warrants transferable. But he was showing a reformer's impatience when he recommended a general act for quiet- 
ing titles to real property by giving a right of action to any claimant against any other claimant to determine "which has the superior equity or right to possession." And he was prepared to break with a very long tradition in the common law of real property in recommending that claimants settling in good faith and subsequently being evicted be allowed at least two-thirds of improvements done, noting with approval that this was the practice in Kentucky and other western states and had arisen from uncertainty and conflict in titles. As attorney general, Hastings' principal involvement with proprietal concerns was in enforcing the state's claim to title over the waterfront property of San Francisco, against both the lessees of the same and against the City. This was to spur on waterfront improvements by the building of new wharves, etc., by the state. It was also to evict tenants who had either not paid rent or failed to perform the terms of their leases. If "Philosopher" Pickett wanted to see the grasping hand of Hastings under the table, it is worth pointing out that the effect of the evictions would be to put the property at the disposition of the legislature and the revenues from the same into the treasury. Hastings' traditionalist instincts were tempered by a large and very real concern for the public weal in the new "instant state."

In turning to Hastings as lawyer, in attempting to assess how (and in what way) he was learned, one quality of the man demands emphasis. He was not by nature sedate and pensive. The activism and adventurousness that had impelled him across the Continent in three stages in a little over a dozen years, despite substantial blandishments to stay put at each stage, was always in conflict with the requirement for temporal detachment, reflection, and infinite painstaking that first-class judicial activity demands. Contemporaries remarked that he was always on the go. Nowhere is this better revealed than in his report, as attorney general, to the state comptroller, February 4, 1852, in the matter of unpaid 
state revenue from Tuolumne county. ${ }^{14}$ At the comptroller's request, Hastings had taken horse to that Forty-Niner county, confronted the county treasurer and the sheriff (the tax collector), and straightened out the chaos of ignorance and misfeasance in short order. He found mitigating circumstances for the local officials' failings-among others, that the primary form of taxable property in Tuolumne was gold dust and so easily "concealed from the Assessor or shipped to the Atlantic States." Nonetheless, he gave strict instructions for proper assessments, tax collections, and regular payments to the state, left directions to the local district attorney to prosecute delinquents, and rode back to Sacramento with $\$ 1578.63$ in cash against the revenue owed for 1851 . The attorney general's direct and effectual intervention was pure Hastings activism. Hastings could never play a passive role. There is the possibility that he found the judicial role as boring as he found it impoverishing.

Hastings' tenure as chief justice of the California Supreme Court is well evidenced in the first volume of California Reports, reported by his associate, Justice Nathaniel Bennett. In the five terms of this first court, March 1850 to June 1851, the bulk of the per curiam opinions (and most of the decisions were per curiam, that is, delivered on behalf of the whole court) were delivered by Bennett. Justice H.A. Lyons delivered very few opinions. Chief Justice Hastings delivered thirty-three per curiam opinions, a separate opinion finding with Bennett and constituting with his the decision of the court, six dissenting opinions-more than either of his associates-and in one case delivered no opinion at all on the grounds that the record of the case at first instance had "been destroyed in the late fires. . .."15 Commentators have called attention to Lyons' minor role in the court, and have generally emphasized Bennett's very considerable activity. Bennett was a remarkable jurist-prolific, sometimes a bit too prolix, but always thoughtful and learned, and invariably a close reasoner. 
Because Bennett's labors are more evident, and Hastings' opinions generally more cogent, more forthright, and less searching, Hastings' work can be overlooked. But Hastings followed certain consistent lines. Rather more than Bennett he demonstrated a willingness to avoid procedural technicalities. He and Bennett split in Constant v. Ward, Hastings holding that where notice of argument was given by the appellant, the respondent could move for affirmance of the judgment upon the appellant's nonappearance even though the respondent had not (per the Practice Act) given notice of argument. ${ }^{16}$ He differed with Bennett again in Osborne et al. v. Elliott et al. (this time, Hastings in the minority), the majority holding that the plaintiffs could not maintain an action without showing performance or an offer to perform the contract, Hastings not finding in the record any evidence to show either inability or refusal on the part of the plaintiffs to comply substantially with the contract. ${ }^{17}$ Hastings was adamantly opposed to fictions and fictitiousness. In The People ex rel. Alexander Campbell v. Clark, Hastings for the majority held that a statute declared to take effect "from and after its passage" takes effect at the very moment of its approval by the governor; Bennett held that it did not take effect until the next day, the day being indivisible. Hastings was categorical: "To hold that a law operates all that part of the day of its passage prior thereto, is as absurd and as much of a fiction as the old doctrine that, by relation, it should commence running on the first day of the parliament." ${ }^{18}$ In a notable dissent in Lineker v. Ayeshford, taking to task the obiter in the majority's opinion that " it is elementary law in support of which, no authority need be cited that a suit may be brought upon a bill of exchange in the name of a fictitious person," "Hastings concluded:

If the above doctrine be correct, any one can readily conceive with what facility our records may be made up of fictitious beings, mere shadows. Besides, this doctrine is fraught with much mischief; it encourages the drawing of bills in favor of 
fictitious parties; a practice which has always been condemned by the Courts of England, as such bills were at one time both in England and France employed as a cloak for usury and fraud. ${ }^{19}$

Hastings was a great respecter of the jury-an article of faith in our branch of the common law tradition that had a particular hold on frontier sensibilities. A jury verdict should be interfered with, he felt, only if there had been a violation of law or established rule of practice, a mistake, or fraudulent acts. Judgment upon a verdict should not be overturned even if there is error in admission of evidence unless the error changed the result, and though defendant's counsel should have moved for a new trial, in no wise should the Supreme Court on the appeal interrupt the verdict of the jury in this case. ${ }^{20}$ Where the verdict clearly went against the evidence, Hastings would reverse the judgment and remand the case. On appeal of a case dating from Summer 1849, he would quash a sentence of death for murder, the verdict of the petit jury, and the indictment of the grand jury, and order a new trial upon a new indictment because "the laws of the country then in force were but imperfectly understood and error and irregularity are found in all of the proceedings of the Courts, especially in criminal cases" and the errors in this case "are so numerous that the execution of the defendant would not be the judgment of the law, but the mere will of the Court and executioner." 21 Indeed, Hastings did not favor a large appellate traffic. In the second reported case of the court, he stated, "We do not think it our duty to encourage appeals into the $\mathrm{Su}$ preme Court of this State, when the amount in controversy is of the character presented by this record."22 In Gonzales v. Huntley E Forsyth, Hastings' obiter, certainly well taken, was that it "must be presumed that the Court had sufficient evidence to authorize the judgment which it rendered, otherwise few judgments of Courts of inferior jurisdiction could be sustained."23

It was in property law that Hastings gave evidence of unusual doctrinal openness and a highly pragmatic 
approach to the problems of property litigation. To the cynic who may remark that there was where his heart was, the reply is that American law in the later nineteenth century, especially out West, could have used more men like Hastings. Hastings shared with Bennett a genuine desire to apply Spanish-Mexican law to matters involving transactions that predated the Americanization of California. As Bennett put it in the preface to his reports:

In the Supreme Court, on appeal, it was necessary to take into consideration, so far as might be done, without infringing positive statutory, or clearly defined and settled law, the peculiar and anomalous condition of the country, of the Government, of the state of society, of the old citizens of California, and of their American invaders. This the Court always endeavored to do, sometimes, perhaps, ineffectually. ${ }^{24}$

Justice Bennett was too modest, because the court was remarkably successful. Neither Hastings nor Bennett manifested the accustomed common lawyer's denigration of the Civil Law tradition. In case after case, Joaquín Escriche y Martin's Diccionario Razonado de Legislación Civil, Penal, Commercial, y Forense ${ }^{25}$ in hand, they wrestled with Spanish-Mexican law, especially possessory, matrimonial, and testamentary matters, willing the ends but not always seeing clearly the means to arrive at a substantially equitable conclusion. The effort was very nearly singular in the annals of the common law tradition. Yet Hastings more than Bennett caught the applicability of Civil Law doctrine to the unfolding law of property in California. Three of his six dissents grew from his willingness to shape the law of property in a most unusual pattern. Hastings believed that the principal hurdle both to establishing civil order and opening up California to economic development grew from unquiet title. The way to clear the hurdle was to shift the emphasis, at least for the time being, from a concern for title to a concern for possession. It was not a misplaced emphasis-it was an evocation of the primal origins of the common law in the great twelfth century legislation of Henry II. In the third reported case, 
March term 1850, Hastings and Bennett split on what were apparently differences as to what constituted possession at common law, sufficiency of jurisdiction at first instance, and sufficiency of pleadings. But Hastings' dissent went higher than these issues. He argued that the question was not what was the respondent's remedy, or what should be the decision of the court at first instance upon a trial on the merits of the case, but who in fact was in the "quiet enjoyment of actual possession." $\mathrm{He}$ held that, "As well might it be said that he who forcibly and with violence, enters a room in the temporary absence of the tenant, can sustain an action of recovery, because he was forcibly ejected therefrom on the return of the tenant." ${ }^{26}$ In Suñol et al. v. Hepburn et al., Bennett and Hastings disagreed again; the issues were numerous, the Spanish-Mexican law that both justices sought to employ was not clear, and the question of the ability of an Indian to convey raised an issue of policy that was probably insoluble. Drawing in large part on authorities from Louisiana, Hastings stood four-square on the proposition that under Spanish-Mexican law, when an action is brought to recover the possession, the right to the possession must be determined before the right to the property. ${ }^{27}$ Finally, in his dissent in the first leading Pueblo Lands case, Woodworth v. Fulton et al., Hastings narrowed the applicable law to Spanish-Mexican law, and concluded:

The respondent having, in good faith, purchased and taken possession, although he may have acquired no valid title, the defendants having entered as a naked intruder and tresspasser against the true owner or by virtue of a similar right, subsequently acquired, I believe at the time of defendants' entry the respondent had the superior right to the possession of the premises. ${ }^{28}$

Hastings clearly recognized that by the shift from title to possession as the issue in most property litigation, time could be bought to work out ultimate settlements on title claims. This reflected his own way of doing business. Given the current state of property interests and 
the high incidence of litigation of proprietal claims, Hastings' emphasis on possession held out more promise for short-term pacification than would have been the case if there had been a strict implementation of common law real property actions and doctrines. Events proved Hastings correct; it required sweeping state and federal legislative intervention to settle title in California.

The only instances in which Chief Justice Hastings showed himself a stickler for formality and technical correctness in the law were in matters where the results of slipshod practice or drafting would lead to more clouded title. In Harris $v$. Brown, Hastings per curiam damned a parol conveyance made before the reenactment of the statute of frauds in California, finding "no shadow of equity in the respondent's case," and not understanding how "under any system of laws, a verbal understanding between an agent, unauthorized by any written paper, and a vendee who neither takes possession nor pays any part of the purchase money, can be enforced if repudiated by the vendor. ..."29 In Fisher $v$. Salmon, Hastings per curiam made equally short work of a deed executed by an agent in his own, not his principal's name, as being not binding on the principal and not transferring title of the property. ${ }^{30}$ Patently, Hastings had no intention of perpetuating the impossible situation in which he found California property claims when he took the presiding chair on the bench.

Hastings' most interesting opinion, technically a majority opinion, was in fact in almost diametrical opposition to the other majority opinion written by Bennett, and it casts him in a most untraditional light as a property lawyer. Gunter et al. v. Geary et al. came on late in the last term of the first Supreme Court. ${ }^{31}$ Lyons was not present, and Hastings and Bennett agreed on a new trial, though Hastings indicated that he would have reversed the judgment entirely and agreed to a new trial only so that the case could be disposed of immediately and not put over for a full bench. The plaintiffs claimed 
to be owners of a lot on the San Francisco waterfront which was under the low-water mark. A house they had built on pilings on this lot prevented ships from tying up on the water front, and Mayor Geary and other city officials pitched the house into the bay, abating (they alleged) a common nuisance that was in obstruction of navigation. Trial by jury at first instance resulted in a judgment of $\$ 2,000$ against Geary. The judgment was appealed. Bennett, while holding that the city had no title, that the plaintiffs had no title, that the plaintiffs had possession before the city government moved to take possession of the lot, and that the city's officers could not take possession without paying adequate compensation to the plaintiffs-possessors, would have ordered a new trial because the trial judge's charge to the jury as to the power of the officers to abate a common nuisance - that only those who had occasion to use the way barred by the obstruction or those aggrieved by the obstruction could abate it-was clearly wrong and "may therefore have misled the jury." Bennett believed the house was not a common nuisance, and that the damages given by the jury were not excessive. Hastings agreed only with Bennett's reading of the power of any citizen to abate a common nuisance. Clearly, Hastings argued, a house erected in a highway is presumed to be a public nuisance, and the presumption could not be rebutted that a private house, unlike a wharf, was anything but an obstruction, being unsuitable for appropriation to a public use and therefore not subject to being compensated for. "It is well settled, that all that part of a bay or river below low water at low tide, is a public highway, common to all citizens. ... The plaintiffs had no right to the possession, and had no property in that part of the bay, and could have none, as against the rights of the public. As well might the plaintiffs take possession of one of the public streets, fence it in, erect a house thereon, and claim damages for an appropriation of private property to public uses, in case the authorities should remove his 'improvements' as an obstruction." 
Citing both English and American law, Hastings concluded "That the absolute right of a state to control, regulate, and improve the navigable waters within its jurisdiction, as an attribute of sovereignty, cannot be in any manner disputed." That clarion declaration Hastings would reiterate as attorney general in March 1853 in an opinion to the assembly as to the legality of pending legislation to extend the San Francisco waterfront, arguing that an extension of the city front by the legislature for wharves and improvements which did not interfere with shipping and commerce was "unquestionably legal." 32 There was a real perception of economic reality behind Hastings' high notion of state sovereignty. Without the encouragement of commerce, California could never begin to reach its potential.

Serranus Clinton Hastings' juridical forthrightness and openmindedness are even more remarkable when one compares him with the run of lawyers of his age not trained in any institutional setting. At the time Hastings was called to the bar in Indiana, there were eleven colleges or universities offering instruction in professional law leading to a degree, only two of them west of the Alleghenies (Transylvania University, Lexington, Kentucky and the University of Cincinnati, Ohio), and there were a few proprietal law schools, most of them in the East. Only a fraction of those called to the bar in the first four decades of the nineteenth century received any formal instruction either in colleges or proprietal schools of law. Most aspiring attorneys prepared for a year or two of apprenticeship in a practicing lawyer's office, and the master-lawyer's abilities, professional and pedagogical, might or might not be up to scratch. Nevertheless, the apprentice could confidently expect to appear at bar of a superior court, be presented ex parte by his mentor, and with perhaps a question put to him by the bench, be admitted to practice. What the apprentice could have been expected to learn, and to learn well, were instruments, procedure, and a certain forensic skill. What he was likely to learn, at best sufficiently, 
was substantive law. Most lawyers' libraries were inadequate to the task of affording more than an introduction to the law. A strong library contained at least a run of reports for the jurisdiction, perhaps a smattering of reports from a major eastern state. Digests began to appear in the $1840 \mathrm{~s}$ in increasing volume, broadening case-law horizons. Few western lawyers' libraries were so strong, and the student had to do with what his master had. There was, though, one book that every aspiring lawyer could expect to have at hand, and which he would know inside and out: Sir William Blackstone's Commentaries on the Laws of England, either one of the numerous, pirated, editions of the multivolume work of that great eighteenth century scholar, or (more likely) a one volume abridged version, a "Student's Blackstone."

Blackstone, first professor of English law at Oxford (1758-66) and afterwards a judge of the courts of Common Pleas and King's Bench, published the four volumes of his lecture notes as the Commentaries (176569). Lucid and elegant (even later editors could not much maim the prose style), Blackstone's work gave the appearance of comprehensiveness and maintained an air of authoritativeness. But it had the shortcomings of lectures, even lectures thoroughly reworked for publication. The treatment of all the branches of the law was too even, papering over the uneven scholarly development of certain aspects of the substantive law. Perhaps a more serious defect was that it did not represent the heavy procedural emphasis, the centralness of the forms of action of the common law, because of Blackstone's desire to make systematic, symmetrical, and rational a legal system that begged all these virtues. To impose order on the common law, Blackstone chose to fit it into an explicit Roman Law arrangement. After a brief Introduction, defining law and praising the "British Constitution" with a short, pungent description of early English law, the common law, Civil and Canon Laws, and statute law, he set down the "Laws of England" in four books: 
Book I The Rights of Persons (14 chapters)

Book II Of The Rights of Things (26 chapters)

Book III Of Private Wrongs (17 chapters)

Book IV Of Public Wrongs (32 chapters).

The first two books correspond in form (not, of course, in substance) to Justinian's Institutes; books III and IV bear resemblance to parts of book II and most of books III and IV of Justinian, though with a much greater emphasis on crime (Blackstone, book IV) than Justinian was concerned with. This Romanist structure gave greater clarity to the common law than it in fact enjoyed, but it was this clarity that both assured Blackstone's survival into the second decade of our century and gave his work a longer vogue and greater influence in American law than in English law. By accident, circumstance, intention, and development, American law put more emphasis on substantive law than adjective law, less emphasis on the forms of action and more on the rights extended and the rules governing those rights. When American scholars turned to analyzing American law, as Joseph Story did in his Commentaries on the Constitution (1833), Blackstone was their touchstone.

Serranus Clinton Hastings was a Blackstone-barrister. Though he was familiar with English cases, as is evident from his citations of them in practice, his understanding of English law, of the entire Common Law tradition, was basically derived from Blackstone. The impact of Blackstone was in fact liberating, and the forced rationality gave Hastings a workable grasp of the law. In this, he was not alone. Another Blackstonebarrister, admitted to practice in Illinois the year after Hastings was admitted in Indiana, was the epitome of the frontier lawyer, suspicious of mere formality, concerned with substance and substantial "equity," using all the law he knew: Abraham Lincoln. Hastings, though, unlike Lincoln, had one added dimension of knowledge that gave him a real advantage in dealing with the law. He had enjoyed a sound Classical education, finished 
off by his year of schoolmastering. Blackstone and law-on-the-frontier stimulated the innovatory and questioning application of the law characteristic of Hastings' chief justiceship. His Classical training gave sophistication to his legal scholarship, providing a broader horizon than many of his contemporaries learned in the law. Hastings was not a great legal scholar or jurist. He was a sound lawyer and judge. His intelligence was perfectly married to his learning and his experience in Classics and the law. It made him unusual in his time and place.

Serranus Clinton Hastings had intended the College of the Law that bore his name to preserve the best of his own development in the law while providing more thorough and systematic direction than he had had the opportunity to obtain in learning the law:

In America, I must repeat what I have said before, in our law schools we teach too much. ... We should have instructors or guides to show us the way, and be left to surmount its intricacies and difficulties through our own exertions.

We should do in the law what was done in the great hegira of 1849 from the borders of the Western States across the plains, deserts, and mountains, to the shores of the Pacific. Guides were employed who were explorers, to point out to the emigrant how to reach his destination in the shortest space of time, and with the least expenditure of physical force. ${ }^{33}$

This was the Forty-Niner, a voice from the past, proud, nostalgic. Sadly, when he spoke these words in 1879 to the second class to enter Hastings, the Forty-Niner's wagon train was already going in a different direction, under the all too able whip hand of John Norton Pomeroy, the guide chosen by Hastings himself. Dr. Pomeroy had very different ideas about what a law school should do in training lawyers-not for 1849, but for 1879 . 


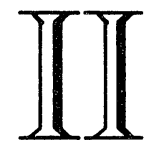

\section{Trials and Ties}

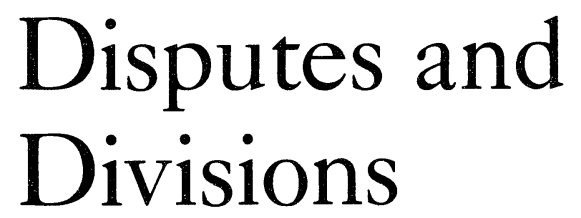

$\mathrm{T}$

HE LIFE of the Hastings College of the Law has been short and uneventful, covering in all about eight years." Thus spake, with sophomoric naiveté bred of ignorance and possibly arrogance, the University of California's Junior Class in The Blue and Gold, the yearbook for 1886. ${ }^{1}$ From the idyllic scholarly Elysium on the bay's eastern shore, the prospect of San Francisco was patently obscured by a haze that was more than fog. In the eight years-admittedly short-since the inception of Hastings College, the College had begun, established its program, and taken in more students, on an average, than it would again until the early 1930s. Uneventful these years were not. At the outset, two formidable ladies opened the doors of Hastings, and hence the doors of the courthouse, to women aspiring to be lawyers. The more perfect union between the College and the University, envisioned by the Founder and so devoutly desired by him, was not consummated, with profound results both for Hastings and the University which continue to this day. Within a few years, the Founder on the one hand and the principal professor and the Board of Directors on the other hand had fallen out, and the independence of the College was abolished by acts of the legislature that failed in their purpose only because they were dashed by the State Supreme Court as unconstitutional. High drama attaches to these 
events, and there is the poignancy of tragedy about them. Even if the fact could not be perceived by the gentle young scholars of Berkeley, these eight years were yet a time of trials (figuratively and literally), of ties that failed to bind, of disputes that raged, and divisions that poisoned old alliances, eroded new hopes, and left enmity master of the field where once amity had reigned.

The first meeting of the Board of Directors of Hastings College of the Law took place on June 6, 1878, at the rooms of the San Francisco Bar Association, on the second floor of 634 Sacramento Street, between Montgomery and Kearny, formerly the quarters of the Pacific Club. The meeting was at the invitation of the Founder, and Directors W.W. Cope, T.B. Bishop, O.P. Evans, J.R. Sharpstein, and T.I. Bergin were present; Chief Justice William T. Wallace, Col. J.P. Hoge, Delos Lake, and S.M. Wilson were absent from the City. "The Founder stated that having transferred to the Directors all future control of the College, it now is necessary that a Dean and Registrar should be appointed."2 By unanimous vote Serranus Clinton Hastings was appointed Dean, his eldest surviving son, C.F. Dio Hastings, Registrar. Curriculum planning was put over to a future meeting of the full Board. The Registrar was ordered to enter upon the records of the College the act signed into law on March 26, 1878, establishing the College; the address of the Founder given the day before at Berkeley "expressing his own views as to the Plan and Organization and of the meaning and intention of the Founder relative to the same;..." and the vouchers of payment into the State Treasury of the sum of $\$ 100,000$. The meeting was adjourned. Before the first meeting of the faculty with the first "junior" class on August 8, 1878, the Board met three times more, establishing the Professorship of Municipal Law (salary $\$ 300$ per month), appointing Dr. John Norton Pomeroy to that chair, directing him to draw up his "whole system" of legal education to present to the Board, and requir- 
ing him to lecture ten hours per week, the hours to be determined by him. Nothing more than this was prepared by the Board for the opening of the College. Establishing curriculum and quarters, making arrangements for the Rev. Dr. William Platt to be Professor of Legal Ethics, securing the agreement of the San Francisco Law Library to allow Hastings students to use it as the act directed (which agreement was literally forced from the library), and the registering of the first class of 103 students fell entirely to Hastings and Pomeroy. Pomeroy no sooner arrived from Rochester, New York, than he was faced with preparing a curriculum. He was more than up to the task. For Serranus Clinton Hastings this was the first and the last time that he was fully involved in the running of his College.

Despite short planning time and the Board's slight engagement in the actual beginning of operations, the College was launched and fully functioning by the second week of August. During the fall and early winter the Board took hold of its responsibilities and made a number of fundamental decisions of far-reaching import. First, Colonel J.P. Hoge was elected vice-president of the Board; since the attendance of the current chief justice, president by the act, could not always be assured, it was essential that in Hoge the Board had the chairman who would see it through its early business and controversies. Joseph Hoge was one of the four founding fathers of the San Francisco Bar Association and its first president, from 1872 to 1879 . Intimately involved with him in the foundation of the Bar Association, and its president from 1886 to 1889 , was Samuel M. Wilson, his law partner in one of the City's most successful firms, and also a founding Director of Hastings. Hoge and Wilson had been in partnership in Illinois before they came to California in the early 1850 s. Hoge was a practiced politician. He served two terms as a congressman from Illinois. In 1878-89 he was president of the California Constitutional Convention that 
produced the Constitution of 1879 , still in force in California. As chairman of the judiciary committee of the convention, Wilson was put to a test of statesmanship. The demand for junking the Constitution of 1849 came from a new, surging working class and small-farmer element in California society that had no time for the politics of deference, demanded tax reform and social service legislation, was in full cry against the political control of the Southern Pacific Railroad and its magnates, distrustful of legislators and the judiciary, and, hysterical over continuing Chinese immigration, adamantly opposed to granting any further rights to Chinese already in California. The resulting document was an enormous, complex, poorly drawn, confusing instrument, a large proportion of which should have been strictly statutory, which has required a century of constitutional revision committees and annual rounds of amendment to make it workable. It was Hoge and Wilson who provided the conservative, legalistic pressure which saved the convention from some of the most egregious excesses. Despite their involvement at such an august level, both Hoge and Wilson were intimately and continuously involved in Hastings' direction during its first academic term. The Board accepted the resignation of C.F. Dio Hastings as Registrar and appointed the Founder's brother, Charles P. Hastings, in his place, in August; established that tuition would be free, with only a ten-dollar registration fee; adopted by-laws for the Board; and confirmed Platt's appointment. On October 18, 1878, the application of one Sit Ming Cook for admission was unanimously rejected-perhaps a small backwash of the anti-Chinese hysteria, which was not confined to California workers. Sit Ming Cook, of Hong Kong, is listed as a member of the Hastings junior class, 1878-79, in the Register of the University. ${ }^{3}$ Whether the Board's action terminated his study, or whether it was nullified by administrative practice is not determinable. It would be a long time before another Chinese name appeared on the College's 
student roll. At the same Board meeting, the application of Mrs. Clara S. Foltz for admission was laid on the table for consideration at the next meeting.

The next meeting was almost three months later, January 10, 1879. The day before, the first day of the second semester, Clara Shortridge Foltz of San Jose, attorney-at-law, attended class at Hastings. The Board, at its meeting, unanimously "Resolved that women be not admitted to the Hastings College of the Law."4 The Registrar was directed to inform Mrs. Foltz and another applicant, Mrs. Laura De Force Gordon, of the resolution, which he did the next day. The ladies stopped attending class, but decided to take other steps to secure admission. Thus was joined an epic struggle between two very determined women lawyers and some elderly and conservative male lawyers that levelled the last formal barrier to women's education in California and drove the first wedge between Serranus Clinton Hastings and his hand-picked Directors.

Clara Shortridge Foltz was one of the most formidable Californians of her generation. She was the antithesis of everything that Victorian convention believed a gentlewoman should be. She was born in the Midwest, the daughter of a "Campbellite," a Church of Christ, minister of that extraordinarily evangelical sect that had the odor of inordinate enthusiasm about it and was considered heterodox by all mainline Protestant churches, preaching as it did the imminent Second Coming of Christ and rejecting all credal formulas. She was insufficiently schooled for her time-three years in an Iowa girl's seminary between the ages of eleven and fourteen. She eloped at the age of sixteen to marry a young Pennsylvania Dutchman of wandering disposition and slight promise. This heady passion had required that she give up her respectable job as a schoolteacher in Illinois, and she descended to being a dressmaker in Oregon after she and her husband moved there in the early 1870s. Worse was to come. At the age of twenty- 
seven, in 1876, having come to San Jose just two years before with her husband and five small children, she divorced Jeremiah Foltz, taking custody of the children. She was already notorious in San Jose: she had actively involved herself in local politics, pressing strenuously and successfully for a paid city fire department, and speaking on every possible occasion for sexual equality in general and votes for women in particular. Despite such conduct she had not been disowned by her siblings or father (who had given up the cloth for the long robe, and come to San Jose to practice law), but had even been encouraged in her course of action. They helped her in her search for a local attorney who would be willing to take her into his office for legal training. After having been told by one attorney that despite his respect for her parents, he thought a "woman's place is at home" and that he would help her find a position in the public schools, she found one sympathetic San Jose attorney who agreed to train her. In 1876 she began reading law with C.C. Stephens, and just as soon mounted a whirlwind campaign directed at amending section 275 of the Civil Procedure Code to substitute "any citizen or person" for "any white male citizen" as a basic qualification for admission to the bar. The fight took two years, and the Woman Lawyer's Bill was not home free until Mrs. Foltz, by her own account, stormed past the sergeant-at-arms into the governor's chambers, and persuaded Governor William Irwin to fish S.B. 66 out of a pile of discarded bills and sign it just as the clock struck midnight and the legislative session ended. There was a grand irony in this scene. The act creating Hastings College of the Law had been signed a few days earlier by Irwin; the Woman Lawyer's Act was signed as the last act of the same session. Clara Shortridge Foltz and Hastings College of the Law were already conjoined in destiny.

Whether Foltz was more sinned against than sinning, her cause more just, her aspiration more noble than the base conservatism that would deny it, her ca- 
pacities and eloquence more considerable than those of most of her opponents, were considerations always lost sight of because of her manner and personality. She was pugnacious in the extreme, her pug nose a point of comment in relation to her pugnacity. Her fearlessness was beyond question. But there was an assertiveness about her that no one-not even her adherents and allies throughout her long career-found appealing. She was a massive egotist, niggardly in acknowledging the help and support and contributions of others. Her autobiographical "Struggles and Triumphs of a Woman Lawyer," serialized in her Los Angeles suffragette monthly, New American Woman (1916-18), was a sustained self-encomium of exaggerated facts and biting invective against enemies and allies in the women's movement. It revealed some paranoia, an absence of graciousness either in victory or defeat, and a compulsion to take credit for everything that had been achieved in the movement in California. As she aged, her egocentricity worsened. She was less than just to Laura De Force Gordon, her cohort in the Hastings case, asserting vehemently, "I am that woman [first admitted to practice in California] and none other can claim that distinction, which has gone down in history a thousand times," Gordon having been admitted to practice only after "I had mandamized the University and the Hastings Law College Directors...." And she never acknowledged the sterling leadership that the first Hastings woman graduate, Mary McHenry Keith, ' 82 , gave to the suffrage movement in California and the West. Foltz probably considered Keith one of the "pink tea brigade" of "rich women who have taken possession of the cause and have got into the bandwagon. ..."6

Laura De Force Gordon was made of less stern stuff, although she was admitted to practice in San Francisco in 1879, less than a year after Foltz had been admitted, in September 1878, in 20th District Court in San Jose. But Gordon, as publisher of the Oakland Daily Democrat, had from 1877 been very much in- 
volved in the struggle for women's rights, and had been a supporter of Foltz's battle for the Woman Lawyer's Bill. She made common cause with Foltz for admission to Hastings, and while Gordon was not plaintiff of record in Foltz v. Hoge et al. Directors of Hastings College of the Law, her omission might well have been related to Foltz's pursuit of her own self-aggrandizement. The public press, in satirizing the whole case, made Laura Gordon as much as Clara Foltz the butt of its unseemly ridicule. Gordon's subsequent career in practice ran a close parallel to Foltz's in terms of type of practice, degree of success, and concern for the problem of the indigent defendant in criminal trials. She could never equal Foltz in quick riposte, could never have demolished a male attorney on the other side at bar who suggested that Mrs. Foltz might better be at home raising her children with a curt, "A woman had better be in almost any business than raising such men as you." Laura De Force Gordon does, however, deserve a generous entry in the honor roll of the struggles for women-in-the-law and women-under-the-law. She was the second woman attorney in the state, and her career as much as Clara Shortridge Foltz's proved that a woman could succeed in a male-dominated profession.

A few days after Clara Shortridge Foltz began attending classes at Hastings and was barred from continuing, she applied to Judge R.F. Morrison, presiding, 4th District Court, for leave to practice in San Francisco, presenting her certificate of admission to practice granted by the 20th District Court. Her intention was probably less to practice in San Francisco (since she was well settled in San Jose) than to be admitted to plead in propria personna in the action she meant to file in the 4 th District against Hastings. Her application hit a snag when Judge Morrison denied the application; but he appointed a committee of three eminent attorneys to examine her qualifications. One member of the committee was W.W. Cope, a former supreme court justiceand a Director of Hastings! The committee reported 
favorably, and Judge Morrison duly admitted Foltz to practice in the 4 th District. Meanwhile, Gordon applied to the California Supreme Court for a writ of alternative mandamus directed to the Hastings Board to admit women. On February 10 Foltz applied for a writ of alternative mandamus to the same end in the 4th District Court. The supreme court remitted Gordon's petition to the district court for consolidation with Foltz's action. On February 13, Directors T.B. Bishop and Delos Lake were appointed counsel for the respondent by the Hastings Board. Judge Morrison granted the alternative mandamus on Foltz's petition, directing the Board to admit her or show cause why not.

Oral argument on the show-cause in Foltz v. Hoge et al. was heard by Judge Morrison on February $24{ }^{7}$ Foltz's case was simply that the 1868 act creating the University of California contemplated affiliation of medical and law colleges with the University in which the standards for admission would be the same as for other departments of the University; the University of California admitted women in all departments; the 1878 act creating Hastings made no explicit special qualifications for admission to law study, neither did it make provision for the exercise by the Board of Hastings of any discretion to make rules governing the law college inconsistent with the rules governing the University as a whole; and Hastings was the law department of the University, bound by its rules and without authority to exclude the petitioner on the basis of her sex. Counsel for the Board argued that Hastings was not subject to general University rules because it was governed by a special trust in which authority was reposed in its own Board of Directors; that no court could review the decisions of that Board and therefore no writ could issue. Director Delos Lake felt compelled to go further, arguing against the "enlargement of woman's sphere" and conjuring up the spectre of how a woman's beauty might make an "impartial jury" impossible if she appeared as counsel for a criminal! As the Board's own 
case on appeal would implicitly recognize, its case at first instance was fatally weak. On March 5, Judge Morrison delivered judgment for the petitioners, Foltz and Gordon, in the conjoined action.

The Board, despite the view of the Founder that the law was with the ladies and that he did not favor an appeal of Judge Morrison's decision, filed an appeal with the Supreme Court. Before the appeal came on for oral argument in the Supreme Court, Foltz passed her third examination to practice, this time before the supreme court of the state, and on December 6 was admitted at its bar. She appeared in propria personna as respondent, established that mandamus was the proper and only remedy, reiterated her argument as to the relationship of Hastings and the University, and submitted that discretionary power to regulate and manage could not be used to exclude one class of citizens while remaining open to others; that the power to regulate is not the power to prohibit, and that the by-laws, rules, and regulations of corporations are not to be contrary to or inconsistent with the laws of the state. ${ }^{8}$ Director T.B. Bishop argued a stronger case than the College had managed in district court. His argument was that the statute and subsequent payment by Hastings of $\$ 100,000$ constituted a complete contract between Serranus Clinton Hastings and the state; that the College was not a corporation but a private eleemosynary perpetual trust, the nature and character of which may be ascertained by analogy to corporations created for similar purposes, and the perpetuity so created had express sanction of the state constitution; that the Directors named in the trust created by contract are the trustees with entire control and management of the trust, subject only to supervision of a "Court of Chancery" [i.e, a court of equity]; that no power is reserved either to the state or the founder, the trustees having entire control not subject to visitorial power; that the very nature of the institution presupposes the necessary powers of fixing the qualifications of students, of exercising a 
"wise and enlightened discretion" in government and discipline, and this power being given to the Directors includes the right to "decide that it is not for the best interest of the College to admit females." He argued further that the petitioner has no clear legal right, without which right she cannot maintain this action, and mandamus never issues when the performance of the duty rests in discretion; that the directors are not controlled by the general law regulating the University, for while the College is the law department of the University by the 1878 act, the act gives no control of it by the Regents, and the College is a branch of the University only for the "purpose of enjoying the sanction of its name, and the receiving of degrees"; and that the law has never given females the right of admission to the University, that claim being based-untenably-on sect. 17 of the Political Code, which if it were allowed, would make women eligible for every non-elective office in the state. In short, the Directors' argument was that by a contract between the Founder and the state a perpetual, self-governing, non-corporate trust had been established which was not part of or subject to the regulations of the University, not bound by the laws of the state governing the University, and related to the University only for the use of its name and the granting of degrees, and that the Directors as trustees of the trust had discretion in all matters of governance, including admissions.

In its unanimous judgment in favor of the plaintiff-respondent, Clara Shortridge Foltz, filed on December 20, 1879, the Supreme Court made short work of the Hastings case. ${ }^{9}$ Dealing first with the issue of "affiliation" of Hastings with the University, it found that the 1868 act creating the University presented a "complete scheme" of affiliation, prescribing general features of the plan for the government of a future college of law. The court held that the plan for the organization and government of Hastings set forth in the 1878 act "does not materially differ from that which is contained in the act to create the University. ..." The 
court turned next to the appellant's contention that the Hastings Directors had discretionary power, holding that as the 1878 act gave no express absolute discretionary power, neither could such power as claimed by the Directors be implied from the provisions and general intent of the act. Moreover, the court held, there was nothing in the general framework of the 1878 act that required the Directors to have greater powers over admissions than those possessed by the Regents and Faculty of the University over students at large. Then, in a rather more sweeping manner than the issue warranted, the court declared:

It was, in our opinion, the intent of the Legislature, that the College, when established, should affiliate with the University, and be governed by the laws applicable to the University, except as otherwise provided, either in the Act of 1868 or the Act of 1878; that the University and the affiliated College should constitute one institution and be governed by the same laws, with only such special provisions as might be required for the harmonious operation of its different branches.

The express provision in sect. 8 of the 1868 University act for the boards of affiliated colleges to control the property of a college so affiliated was construed to exclude absolute discretionary power of such boards; if such discretionary power existed, why should the particular power of control over property have been specially conferred? The court conceded that no strict legal right to be admitted to the College existed; the Directors could exclude applicants of bad moral character, or of too young age, or of insufficient capacity to study the law, or who applied after the College had as many students enrolled as could be instructed. But this was not an unlimited discretion, and could not be taken to maintain "that the Directors are not subject to the laws applicable to the University." The "suggestive provision" of the 1878 act, that Hastings " shall matriculate students who [may] reside at the University of the State" " [sect. 9 -incorrectly cited in the report as sect. 8], the Court took to mean students of the University. The court then 
set down the admissions criteria of the University: requisite age, residence in the state, and good moral character. Females were then and had been for some years admitted to the University. The provision of sect. 17 of the Political Code, that words in the masculine gender comprehended as well the feminine gender, "would seem to entitle females to enter the University as students at large." The court concluded by pointing out that females by law are entitled to be admitted as attorneys in all state courts on the same terms as malesa tacit tribute to the respondent. The College was founded to afford instruction to those desirous of admission to practice "as well as those who have been admitted." The College "was affiliated with the University, and thus became an integral part of it," and so subject to the same general legal provisions as are applicable to the University. Therefore, "the same general policy which admitted females as students of the University, opened to them as well the doors of the College of the Law."

The signal victory of Foltz and Gordon was reported two days later to the Board of Directors of Hastings College of the Law by the Founder-Dean, and the report was "placed on file." Judge Delos Lake, whose feeble advocacy had contributed to the defeat at first instance, moved a resolution that no one admitted by the Supreme Court of California as attorney and counsellor to practice in all courts of the state be admitted to the College except by a special order of the Board of Directors. The resolution, a patent slap at Foltz, whose status it covered perfectly, was passed unanimously by the six Directors present (Lake, Evans, Cope, Bergin, Wilson, and Bishop). The Directors evidently had not yet read the court's opinion: in its conclusion, it had expressly provided for the admission of those already/ admitted to practice. The Board's resolution does not appear to have kept the feisty Foltz out. Though there is no record, either in the Board's minutes or in the University Register, that she attended Hastings after the court's decision, she claimed to have attended Hastings 
for two years, withdrawing without taking a degree or completing the course only because of the increasing pressure of family and practice. The Register is not entirely reliable for enrollees; Mary McHenry began at Hastings in 1879, but is not carried in the Register for that year (neither are three other of her UC and Hastings, '82, classmates, William Slack, M.A. Dorn, and E.G. Knapp).

Foltz must be taken at face value when she argued that her sole intent in applying to Hastings was to increase her competency and gain greater confidence in her practice. But further academic, legal education really was irrelevant to a sublimely self-confident, learned, and peerless advocate who, on the hearing of her case before the Supreme Court, was complimented from the bench with the words, "I have never heard a better argument, for a first argument, made by anyone." ${ }^{10}$ She had other battles to fight. From a practice specializing in probate and divorce, she moved increasingly into criminal law. She was the creator of the California parole system (1893), and a long crusade for criminal law and penal reform culminated in the $1920 \mathrm{~s}$ with the adoption, in California and in more than thirty other states, of the "Foltz Defender Bill," the public defender system. Also, journalism, especially in furtherance of women's rights, occupied her. From the early part of the century she resided in Los Angeles, threw herself into the suffrage movement (though she was not as prominent as she claimed subsequently to have been), and in 1910 became the first woman deputy district attorney in the state. She was actively involved in Republican politics, and in 1930, at eighty-one, she ran in the Republican primary for governor on a women's rights platform, going down to glorious defeat with about 3500 votes.

For all her works and fame, having broken open Hastings remained in her own eyes her greatest achievement. The most characteristic and most widely circulated photograph of her shows her standing 
straight and looking defiant, her right hand on a law book, a mortar-board on her head. She had a few skirmishes yet to fight with Hastings' Directors. In October 1889, she applied for the degree LL.B. to be conferred upon her, though she had not completed the course. Directors O.P. Evans (her adversary in 1878-79) and Robert P. Hastings, LL.B. '81 (a son of the Founder) moved that the degree be conferred. The motion lost. But in 1925, almost as a voice out of the past come back to haunt the Board, Clara Shortridge Foltz requested that the degree LL.B. be awarded her as an honorary degree. The request was denied on the grounds that the Board had no authority to grant any degree save upon completion of the regular course of study. If niggardly, at least the Board's act was consonant with the College's consistent policy from that day to this of awarding no honorary degrees. Almost a half-century after her death, the old battler has received a higher honor from the College than an honorary degree could ever have accorded: in the early 1970s, the women law students at Hastings renamed their organization the Clara Shortridge Foltz Society, and tee-shirts bearing the proud mien of the honorée are sported by women and men alike.

The first beneficiary of Foltz and Gordon's pioneering effort was Mary McHenry, the daughter of a Louisiana judge who had settled in San Francisco. After a ladylike education, including early schooling at the Grace Female Institute, Mary McHenry matriculated at the University of California, graduating A.B. in the Classical course of the College of Letters in 1879. Her senior thesis, "The French considered as the Language of Polite Europe," might have the faint odor of dilettantism and thin conceptualization about it, but it evidenced her earnestness and her historical and language interests. President John LeConte, in his own hand, certified that she had "sustained a high character both as lady and as student" while at Berkeley. ${ }^{11}$ With such a testimonial and such an academic record, she was 
hardly excludable from Hastings. She entered probably in the fall of 1879, before the final outcome of Foltz $v$. Hoge et al. She excelled at Hastings. Her papers contain lecture notes of Prof. Pomeroy's second-year course and a number of third-year final examinations, which together with Pomeroy's printed Syllabi afford considerable insight into the earliest curriculum. The lecture notes also testify to an assiduous and thinking student. She apparently never suffered the derision of fellow male students that had been accorded Foltz in the first two days of her attendance, in January 1878; there was no repeat performance of male students playing follow-the-leader, such as they had greeted Foltz with: when she coughed, all coughed; turned a page, all turned a page; moved her chair, (all, etc.). On the contrary, McHenry was so popular that at the second Hastings commencement, May 29, 1882, she was one of five student speakers, "representatives chosen from the class." Her speech, "Origin and History of the Last Testament," is extant, in her own hand. ${ }^{12}$ Full of youthful learning, and a great deal of youthful yearning, it is solidly based on Classical history, Greek and Roman, and her Biblical citations are correct and apt. Her command of Roman Law is phenomenal, even allowing for Pomeroy's emphasis on it. One can suppose that the daughter of a Louisiana Superior Court judge would have considered it no foreign system. She might be chided for relying over-much on Gaius's Institutes, but that was the Roman Law text most usable for an American student at the time. Her treatment of English legal history of real and personal property was conventional, but in this, as in her use of Classical history, she demonstrated the instincts of a sound historian, concerned with the past as something more than a boneyard for the present. Overall, Roman Law came out as infinitely superior to the common law. She damned the latter because of the inferior position assigned women and the inferior protection afforded them by the "Feudal System." The glory of Roman Law to Mary McHenry was 
that it made provision for the familia, which if subordinate to the patria potestas, the power of the male head of the family, nevertheless provided generously in testamentary matters for women. She could speak approvingly of the English Statute of Wills of 1540 which, by giving limited devise of realty, ameliorated the rigors of the law of descent in feudal law, but with reservations: "Highly as the gift [Statute of Wills] should be esteemed as tending to alleviate the condition of women under the Feudal System, it was far from being an equivalent for the great personal and proprietary independence of married women under the Middle Roman Law-an independence whose destruction has so deeply injured civilization." As she neared the conclusion of her oration, Miss McHenry got in a dig at the gentlemen in her audience with a bit of legal punning: "I have heard," she said, "that married women always succeed in carrying their wills into execution during their lifetime." With somewhat forced astuteness, she urged the audience to make testamentary provision before death and get competent legal assistance in drawing the will, citing the sorry case of Longfellow, who had recently died leaving an ambiguous will likely to spawn litigation. She ended with a graceful curtsey to John Norton Pomeroy, and to the Founder for the "forethought and timely liberality on the part of the generous founder of this 'Hastings' College of the Law."

Mary McHenry's valediction is an illuminating measure of what a Classically educated law graduate of early Hastings could do in the way of an academic exercise. It also presages her own career. Alas, it would not be in the practice of the law, but in the service of suffragettes. Though admitted to practice by virtue of the completion of the Hastings course and the conferral of its degree after application to the court, within a year Hastings' first woman graduate married California's most eminent artist, William Keith, twenty years her senior, and sailed off for a two-year sojourn in Europe. Keith, a Scot, was one of the great landscapists of the 
California scene, progressing from a photographic-like realism, a "particularity of place" à la Eakins or Canaletto, to an ultimate soul-meaningful abstractionism of light and darkness, form and color. Her marriage inspired one wag in 1883 to produce six verses of affectionate doggerel entitled, "A Moan from the San Francisco Bar, On Losing an Esteemed Lady Member":

Mary, good-bye, we must forgive the tort;

At least, you've won your case in Cupid's Court;

Your status henceforth,-may's prove no servitum,

And no beginning, but a finis litium;

And may you ne'er encounter that fell woe

Of woman's life,- - divorce a vinculo;

Or find, in time, a trusting wife's deliciae

Turning, midst married storms, to sour saevitiae;

And be the latest Mem. upon your docket,

"A baby's cradle,-—how to stock and rock it." 13

The point was well taken, the direst fears not realized (it was an idyllic marriage until death took William Keith in 1911), and the best hopes fulfilled (the cradle filled).

When the Keiths returned in 1885 they built a house in Berkeley that became the veritable powerhouse of the woman's suffrage movement in California and the West Coast as a whole. Like all the early California women lawyers interested in women's rights, Mary McHenry Keith was an active journalist, writing a weekly column in the Oakland Enquirer in support of suffrage. By 1895, she was California's most prominent suffragette, intimate friend of Susan B. Anthony and Carrie Chapman Catt. She began at home-with the University of California. In 1900, at a testimonial dinner hosted by Phoebe Apperson Hearst for the eminent Berkeley historian, Professor Bernard Moses, who was about to set sail for the Philippines as one of the American Commissioners to take in hand the restructuring of government in America's newest acquisition, Mary Keith as principal speaker was not loath to tax Moses with certain unconscious anti-feminist attitudes he had displayed in the classroom when she was his student. 
She also quite fearlessly suggested to him that the American High Commission accord full rights to Filipino women. She was an intrepid battler for the vote. Less strident, more retiring in personality, more graceful and gracious than Clara Shortridge Foltz, she was also more effective in the feminist cause. She charmed a male auditory. Her husband, who would greet her threat to return to practice (never executed) with a laughing, "Not much you will," was a warm and outspoken advocate of the vote for women, Mary once being urged by Susan B. Anthony herself to unleash William whenever he travelled. In the first decade of the century, to the day of victory in 1911 when women won the vote in California by referendum, she contributed some $\$ 15,000$ to the cause, and tirelessly led it. Her joy at victory was stolen from her by the death of William at the same moment. Though she would live another three decades, she was not of a political inclination, and the death of her husband was a heavy blow. She was a beloved figure in Berkeley. The secretary of the Berkeley Chamber of Commerce in 1911 wrote the accolade that best catches her inimitable quality-that she combined "the life and action of two generations, the younger and the older generations of the present, moulding them together with wit, and gentleness and patience, learned during the years of waiting" for the victory that 1911 brought. ${ }^{14}$

In two ways, quite aside from the admission of women, Foltz v. Hoge et al. affected the future of Hastings College of the Law. The issue raised was the first point of division between Serranus Clinton Hastings, Founder and Dean, and the Board of Directors into whose hands he had committed full power and authority for the operation of his foundation. The Supreme Court of California, in its opinion in the case, first subjected to learned, judicial scrutiny the nature of Hastings' relationship to the University of California, the matter of "affiliation." The falling out of the Founder 
and the Board (and the professor) was intimately intertwined with the question of "affiliation." It is not too much to say that the court's opinion in Foltz v. Hoge et al., insofar as it touched "affiliation," represented Serranus Clinton Hastings' thinking. It most emphatically did not represent the thinking of the Directors of Hastings College of the Law.

What were the fundamental grounds for division, the underlying causes of the increasing growing apart of the parties who had so elatedly and confidently set on foot the enterprise in the spring of 1878? It was Serranus Clinton Hastings' view of the nature of legal education that was the rock on which amity foundered. William Carey Jones, the founder of the Berkeley (Boalt Hall) School of Jurisprudence and for two years a lecturer in Roman Law at Hastings in the 1880s, had had considerable contact with the Founder in the planning stages and early years of the College. As Recorder of the Faculty at Berkeley, Jones was an assistant to President LeConte and present at the meetings during the two years or so that Hastings discussed his proposal with LeConte. For a couple of years, Jones summered in Lake County and twice chanced to take the stagecoach with Hastings. Jones found that Hastings' "ideas were large, though vague and unsettled, on the subject of legal education, and on the kind of law college that ought to be built up in affiliation with the University of California."15 Allowing for Jones' remarks being late (1912) and possibly somewhat self-serving, as a justification for the newly-launched Berkeley School of Jurisprudence, they ring true as to the grandeur-and vagueness - of Hastings' educational ideas.

By 1878, Hastings was a long way from what formal education he had known. His Latin was still sound, the rudiments of his Classical education still retained (nothing wrong with the mottoes, "Detur Dignissimo" and "Fortiter et Recte," that graced the seal he designed, and which is on the dust jacket of this book). He had devoted as much leisure time to reading as a restless 
man of action and of affairs might be expected to set aside. More significantly, shortly before making the final move to establish the College, he had visited Europe for an extensive tour, spending considerable time at European universities. It was this experience, perhaps not very profound (it is doubtful that his command of modern languages was up to the job), but certainly serious and informed by his acuteness as an observer, that issued in his comprehensive and somewhat simplistic survey, "Law Instruction and Law Schools," his Annual Address to the students at Hastings in August $1879 .{ }^{16}$ He looked favorably upon the instruction given at the English Inns of Court, while recognizing how unstructured it was. He found much merit in the German system, which resulted in every practitioner and judge having a "thorough classical and legal education." The German emphasis on history appealed to him, but he was aware that the full-blown German method based on close study of the great Codes was not wholly applicable to the American legal system which, for all its efforts of codification, remained a case-law system. On balance, he came down against the German system, albeit on questionable grounds:

There is one conclusive reason why an American should prefer the system of instruction of his own country to the German method. The culture of the German is too expansive. Its scope is so great and he knows so much, that he is unfitted for the rapid discharge of his professional duties under the Anglo-American common and statute laws. He cannot become a close-reasoning, astute lawyer. His knowledge is too diffusive. His energies are wasted over too large a surface.

Reading this, one can appreciate Jones' remarks. Yet Hastings was equally sure that in American law schools "we teach too much," and that professors should be merely "guides" to show the students the way in the law. Finally, he came down as being "in sympathy with the Germans in their manner of teaching the law," which can only be construed as meaning relatively few classes, while rejecting the German preoccupation with so much 
knowledge as to prevent "close-reasoning." One clue in Hastings' meandering discourse helps unravel the ambiguity even if it does not resolve the contradictions. Hastings' detestation of academic buildings was almost pathological: he sought an educational ambience simpler and less corporeal.

We [Hastings College] have no lecture halls in this city. We are liable to be under the necessity of imitating the peripatetic philosophers, and instruct the young men of this city in the parks and public groves; and this in a city which has in the name of common school institutions erected almost palatial structures in several parts of the city, in place of the cheap common schoolhouse of our fathers.

This diatribe was meant to shame the San Francisco city fathers into providing at least a lecture hall for the College. But it also makes clear that Hastings harked back to a combination of the Socratium, the academe of Plato, the little red schoolhouse, and Mark Hopkins and a student on a log. In short, Serranus Clinton Hastings was a pedagogical primitivist. This was (and is) a respectable tradition. However, for 1879 it was questionable whether anyone actually engaged in teaching the law would find it anything but a hazard as an operational method. Hastings had a very simple view of legal education because he had a very simple view of the law. Both views were fallacies, one built upon the other. At best, Hastings was a Blackstone-barrister, and in the two decades since he had last practiced the law it had begun to change mightily, growing in all those areas in which the classical jurisprudentialism of Blackstone, Kent, or Story was silent. Moreover, Hastings was only faintly aware of what went on in the great law schools of the East and Midwest, and he failed to perceive how rapidly the curriculum (and at Harvard, at least, the instructional mode) of formal legal education was changing.

Of one thing Hastings was certain. The law school must be part of a great university. However, Hastings, who had never been to a university, and not even to one of the nineteenth century's modest liberal arts colleges, 
did not appreciate the full implications of a university. Significantly, he was not entirely aware of the distinction between undergraduate and graduate studies, which was becoming fundamental to the American university under the impact of German-derived influence. While he hoped that most of the students at Hastings would be graduates, it was not his intent that it be wholly a graduate institution. Since it would be open to students with sound schooling in languages and history, it must supply the civilizing civility of the liberal arts tradition, hence his concern that instruction in legal ethics be an integral part of the curriculum. Hastings had great faith in the liberal arts tradition; his son, Robert Paul (Hastings ' 81 ), latterly Director and dean, was a graduate of Harvard College. If the Founder was suspicious of too much instruction in law school, too much formal training, if he believed that the student should not be "taught" but "must learn" by "ratiocination" what the law is and so be "metamorphosed" into a "well-defined legal mind," he nevertheless felt that the law school experience must be built on a sound liberal arts foundation. ${ }^{17}$ As the Founder saw it, it was the liberal arts dimension that tied together Hastings College of the Law and the rest of the University of California.

Though it is not susceptible to proof, it is possible that Hastings' vision of the university was shaped by John Henry Cardinal Newman's Idea of a University (1873), which enjoyed an enormous vogue on both sides of the Atlantic, especially with those who saw the Catholic Christian tradition of education threatened by secularism and materialism. Hastings was a notable convert to Catholicism in early American California, one of those eminent men of redoubtable Protestant origins who were converted by Archbishop Joseph Alemany and the resurgent aristocratic Catholicism of the first three decades after the Gold Rush. Newman's university did not necessarily have to be a sectarian institution. The civilizing mission of the liberal arts would work a reassertion of the ethos of Christian values even in the 
secular university. Newman's ideal was an education that made a gentleman, balanced, tolerant, gracious, of Athenian contemplativeness. One assumes that the restless Hastings aspired to but fell short of such reflective detachment. The Platonic notion of the striving for perfection underlay Newman's educational ideal. Mental cultivation, rather than preparation for a vocation, was the object of the liberal education. If a liberal education was good (morally good) then it must be useful, too. Education teaches a man to go right to the point, to detect sophistry, to discard the irrelevant. "It prepares him to fill any post with credit, to master any subject with facility." 18 So armed, Serranus Clinton Hastings believed that his College, whether sited in San Francisco or in Berkeley, must be related in an organic union to the greater University that would give meaning to the College's ethical and didactic functions. In expressing this, the Founder was unusually clear, concise, and articulate:

This College is not an affiliating college alone; it is a part of the University: and was established not to make lawyers merely, as is generally supposed, but to qualify judges, statesmen, and law-makers; to educate young men who intend to engage in foreign and domestic commerce in a knowledge not only of the laws and constitution of their own country, but of the laws of foreign nations and international law; regarding a knowledge of laws and jurisprudence not only useful as affording good mental training, but of great practical value in every intellectual avocation. ${ }^{19}$

No one else connected with Hastings College of the Law shared the Founder's vision. Perhaps it was not clear enough to be completely understood; certainly it was not detailed enough to be acted upon. All eight of the named Directors were, as the act specified, members of the San Francisco Bar Association and active lawyers in the city. Not one was a college graduate, had been connected with the founding of the University, was a Regent of the University, or would be. Not one had had any experience in formal legal education, save insofar as he had had bar aspirants prepare in his office. Only the 
one other Director, the ex officio President, Chief Justice William T. Wallace, was involved in higher education: from 1875 to 1902 he was a Regent. In the deliberations of the Board, the Chief Justice was more noted for his absence than his presence-understandablyand a certain neutrality on critical issues on his part was likely and desirable. Though all of the Directors were friends of the Founder and held him in some esteem, he had chosen them primarily for their professional eminence, secondarily for their political influence, and not at all for their educational experience or even commitment. The Directors saw the College as a means for producing lawyers, nothing more.

John Norton Pomeroy did not share the Founder's vision either. Possibly, he understood it, though he would have found its contradictions and ambiguities a grievous intellectual failing. As Professor of Municipal Law, in whom was confided the entire legal instruction of the College, Pomeroy was the one didact connected with the enterprise. Pomeroy was a graduate of Hamilton College, New York, 1847, and he had been a schoolmaster. While his legal training was in law offices, he displayed a genuine scholarly bent that a cynic might feel was confirmed by the fact that in his nine years of practice in Rochester, his native town, he had little if any business. In 1864 he published his first book, an elementary introduction to the law, intended for college or academy students. His scholarly reputation was already established when he was called in 1864 to teach law at the University of the City of New York (New York University), which had begun continuous instruction in law eight years earlier. During his six years at NYU, he became a renowned teacher. When he returned to Rochester in 1870 to continue writing, his reputation as the leading constitutional law scholar was founded on An Introduction to the Constitutional Law of the United States (1868). Much of the scholarship of his Rochester period was dedicated to codes and codification, and this recommended him to the Founder, who chose him to be 
the professor at Hastings. Pomeroy had the education, the training, the experience, and the academic eminence that Hastings himself lacked. He also had very definite ideas as to what must be taught in a law school, how it should be taught, and what kind of a product the law school should produce. No civilizing mission for him; a liberal education would have to be acquired elsewhere. The law school was to teach LAW, and what a grand expanse the LAW was! The first year was to be devoted to a Roman-structured introduction to the law of persons and property, with the rudiments of contract, and all served up with an historical dimension. The second year would be devoted to mercantile and commercial law, advanced property with emphasis on estates, trusts, and wills, and equity jurisprudence. The third year was to concentrate on pleading and practice (across the board), medical jurisprudence, international law, conflicts, Roman Law, and jurisprudence. How Hastings must have shuddered when he saw Pomeroy's "Outline Course of Study," readied for the first meeting of the first class in August 1878. Every stricture Hastings levelled at the American system of teaching in the law schools back East (teaching too much) and against the German system (too much knowledge) could be levelled at Pomeroy's curriculum. Patently, John Norton Pomeroy was not going to be merely a "guide" into the law. He was going to be the captain of a magnificent vessel, Justitia, transporting a cargo of aspiring lawyers through storm and shoals to ultimate capacity to command the law itself. Whatever else might have divided Serranus Clinton Hastings and John Norton Pomeroy-differences in background and breeding, life experience, age (Pomeroy was fourteen years younger than the Founder), and temperament-that which opened as a gulf between them was their divergence over pedagogical matters. And to drive them further apart, Pomeroy was so supremely confident of his own mission, so sure of what a law school must do, so convinced of the singular nature of the law school enter- 
prise, that he did not care whether the law school was or was not part of a great university. "Affiliation" was a matter of convenience, not an end to be desired in and of itself.

Serranus Clinton Hastings, whether from arrogance, oversight, ignorance, or a combination of all three, was the author of his own troubles. His intense pride in his munificence (the seal on the dustjacket catches it all) dictated that he would not merely give a gift of money to the University to found a law school, but that the institution would go the route of an "affiliated college" established by and fixed in statute law. A gift to the University would have resulted in almost no exercise of power and slight influence over the creation and operation of the law school on the part of the donor. But the "affiliation"-by-statute alternative almost as effectively barred the donor from much more than an advisory role, unless the trustee-Directors of the statutory board chose to give ear to the donor. Hastings made the mistake of choosing as trustee-Directors men of a very narrow professional perspective. He accounted them friends, but if he was to retain a controlling or even major voice in the institution, he was obliged, by the nature of the eleemosynary trust, to repose in the men he chose the kind of confidence one rests in longtime intimates, and these men were less than that. That he was promptly chosen dean was a gesture of respect, but it was not the proffering of power. The Board was in command. The dean would not teach, and he was not even delegated curriculum planning responsibility. All that was of the essence of the College in its functioning was in the hands of the sole professor-Pomeroy-and the dean was merely a figurehead, the instrument of the Board if it wished to use it, at best a go-between inter Board and professor. It is ironic that the Founder's vision, unclear and imperfectly articulated as it was, might well have found more sympathy, and even a genuine assist in giving it reality, from the president, faculty, and Regents of the Univer- 
sity than it received from his own Directors and the professor he himself had chosen.

The first rift came with Clara Foltz's first day at Hastings in January 1879. Stopped by the janitor from attending, she had appealed to Dean Hastings, who admitted her subject to approval by the Board. The Board's subsequent disapproval was also a disavowal of Hastings' action. He had made clear to the public press, after Morrison, J. directed the College to accept Foltz and Gordon, that the law was solidly with them and that he, disagreeing with the Directors, did not favor an appeal in the case. It was a small matter. It soon passed. The fundamental break came in December 1879, ironically when the dean reported on the decision of the supreme court in the Foltz Case and on the articles of "affiliation" with the University. It was the latter that brought on the rupture.

"Affiliation," from the outset of the University, was provided for and considered desirable by a state institution of limited resources. By the 1868 act creating the University of California, an order of priority for establishing "colleges" of the university was set out in sect. 2: 1. colleges of agriculture, mechanic arts, mines, civil engineering, other colleges of arts; 2 . college of letters; 3 . colleges of medicine, law, and similar professional colleges. ${ }^{20}$ Priorities 1 and 2 were rapidly fulfilled. As early as 1870, however, when the Regents essayed the idea of establishing a law school, nothing came of the plan save the appointment of Stephen J. Field, Justice of the United States Supreme Court, a lawyer of Forty-Niner days, as Honorary Professor of Law (a title without function that he retained for some years after Hastings was founded, though it was not suggested that he teach there). In 1872, Regent John W. Dwinelle moved the Regents to further planning, including conversations with State Supreme Court judges and members of the bar. This might have been the point at which Serranus Clinton Hastings began to think seriously about founding the law school. The Regents found themselves bur- 
dened with more pressing needs, and nothing more happened. The 1868 act (sect. 8) provided that the Board of Regents "may affiliate with the University, and make an integral part of the same, and incorporate therewith, any incorporated College of Medicine or of Law, or other special course of instruction now existing, or which may hereafter be created, upon such terms as to the respective corporations may be deemed expedient;..." the affiliated colleges retaining control of their own property, with their own boards, faculties, and presidents, the students to be recommended by the faculties to receive from the University the degrees of the colleges, the president of the University to be ex officio a member of the faculty and president of the faculty of each college. It was under the terms of this section that Hastings founded his law school as an "affiliated college," the second such (the School of Pharmacy, San Francisco, was the first, in 1873).

As the Supreme Court held in Foltz v. Hoge et al., the 1878 act creating Hastings in its plan for the organization and government of the College did not differ materially from the provisions for affiliation contained in the 1868 University act. Sect. 2 of the 1878 act was the key provision:

Said College shall affiliate with the University of the State, upon such terms as shall be for the welfare of the College and University, and shall be the Law Department of the University. ${ }^{21}$

The faculty of the University would grant diplomas to Hastings graduates, and the president would sign and issue the same (sect. 3); a room or suitable hall at the University was to be set apart for the use of Hastings students (sect. 4); the Dean of Hastings was to be ex officio a member of the faculty of the University (sect. 5); the College would matriculate students resident at the University as well as students residing elsewhere in California (sect. 9). Only in one respect did the Court in Foltz v. Hoge et al. exaggerate the degree of similarity 
between the provisions for affiliation of the 1868 and 1878 acts. By the 1868 act, affiliation was to result in the affiliating institution becoming an "integral part" of and "incorporate" with the University. This might well have been intended by the word "affiliate" in sect. 2 of the 1878 act, but the integration and incorporation were not set down expressly.

There are two ways to view sect. 2 of the 1878 act. One is that it did de jure completely and sufficiently accomplish the affiliation of Hastings with the University. This is untenable. The use of the future tense, "shall affiliate," indicates authorization to do something not yet completed. The Court in Foltz v. Hoge et al. was inclined to the alternative interpretation in finding the legislature's intent to be that when the College was established, it "should affiliate" with the University. The reference in sect. 2 to "terms" clearly indicates discussion and agreement between the two entities, the College and the University, which had not yet taken place. The second view is the correct one. Hastings would, pursuant to the act, affiliate with the University by a consensual arrangement upon terms of mutual benefit. However, what about the words in sect. 2, "shall be the Law Department of the University"? Did the act itself make Hastings the Law Department, etc.? Or would its status as the Law Department depend upon the completion of the affiliation agreement? The use of the present tense would have avoided all ambiguity; but again, the future tense is used, and it is probable that the legislative intent was for the status of the College as law department of the University to wait upon the completion of affiliation.

The first-year class at Hastings had already completed their final examinations before the Regents even considered terms of affiliation with Hastings. At the Regents' meeting, May 10, 1879, President LeConte submitted a "communication" from Serranus Clinton Hastings on the matter of affiliation, and on the motion of Regent Joseph W. Winans (whose son, Joseph Jr. was a 
first-year student at Hastings, UC, A.B. '78), it was laid on the table. At the June Regents meeting, the Founder's communication was read, and Winans moved a special committee be appointed to confer with Serranus Clinton Hastings and prepare a plan for the Regents for the affiliation of the College. Regents Winans, Chief Justice Wallace (president of the Hastings Board) and S.B. McKee were appointed the special committee.

At the Regents' meeting, August 7, 1879, Winans moved a resolution of affiliation by which Hastings College of the Law "shall be affiliated with the University of California and made an integral part of the same, and incorporated therewith ..." on seven specific clauses of terms and conditions "which are hereby made a part of such affiliation and incorporation." 22 . The resolution, it will be noted, followed the 1868 act's wording verbatim with respect to affiliation, integration, and incorporation. Clause one confirmed the method of selection of future Hastings Directors as set down in sect. 1 of the 1878 act, except for making the selection subject to the approval of the Regents. Clause two, however, went far beyond the act: the Founder and his legal representatives would always be entitled to the appointment from among the Founder's heirs or a representative of one Director, the appointment not subject to Regental approval. Clause three was largely explanatory of sect. 3 of the 1878 act with respect to the conferring of diplomas, save that the Regents and not the president would issue the diplomas, subject to the right of the Regents to refuse a diploma "for cause." Clause four reaffirmed sect. 4 as to the provision of a room or hall at the University for Hastings students, "as soon as practicable." Clause five gave the Founder-dean a seat and vote in the Academic Senate of the University for life-something less than the provision in sect. 5 that the dean of Hastings was ex officio a member of the University Faculty (i.e., of the Academic Senate). Clause six was stunning in its sweep: "The said College shall be subject to the dominion of the said Board of Regents in all matters 
pertaining to its management and welfare." Quite aside from what the legal definition of "dominion" might be-sovereignty or lordship, fine old feudal concepts indeed-the powers here arrogated to themselves by the Regents ran directly counter to even the most conservative reading (that, for instance, of the supreme court in Foltz v. Hoge et al.) of sect. 11 of the 1878 act, that "All the business of the College shall be managed by the Directors without compensation. ..." Clause seven gave back with the left hand a bit that the right hand had taken away: numbers and duties of the professors were to be prescribed "and the business of the said College managed" by the Directors, subject to the approval of the Regents. The special committee reported that the plan and method of affiliation which seemed to them suitable was embodied in this resolution, and that it "is acceptable to Hon. S.C. Hastings (having been fully approved by him)...." The Regents adopted the resolution, and the secretary was instructed to communicate to the Founder the "recognition by the Board [of Regents] of the donation that constitutes the above endowment."

The official Centennial History of the University of California argues that the affiliation of Hastings with the University was accomplished by the 1878 act, that the affiliation resolution of the Regents was "unnecessary" and was probably taken only "to demonstrate compliance with the Hastings College Act of 1878." ${ }^{23}$ Besides being an untenable construction of the 1878 act, what this interpretation overlooks is that for almost a century a succession of the University's presidents, finance officers, and counsel to the Regents, and the Regents themselves have continuously and without exception affirmed that by this resolution Hastings was affiliated with the University, and that those same officials have governed their relations with Hastings on the assumption of the validity of the resolution of August 7, 1879. To be sure, clause six proved a chimera, in theory and in practice. But that had less to do with any reserve on the part of the University's imperialistic adminis- 
trators than with the ability of Hastings to go its own way, impervious to machinations in Berkeley.

What the succession of University officials never knew was that the Regents' resolution was rejected flatly, and unanimously, by the Hastings Board of Directors on December 22, $1879 .{ }^{24}$ With the exception of Chief Justice Wallace-acting in his capacity as a Regent, not as a Hastings Director-no one other than Serranus Clinton Hastings was involved in the negotiations with the Regents. That the Regents' plan was acceptable to the Founder can be believed-he wished the full integration that affiliation with the University provided. He might even have begun to have considerable reservations about the direction the Hastings Directors were taking in the administration of the College. But he should not have been surprised at the Board's repudiation of the Regents' resolution. Clause six could never have been assented to by fiduciary trustees aware of their responsibilities if they intended to retain any autonomy, and the Hastings Directors were not prepared to give over the College to the Regents. Present at the December 22 Board meeting were Directors Lake, Evans, Sharpstein and Hoge-with Chief Justice Wallace in the chair (the minimum for a quorum). We cannot be sure that Wallace voted in the unanimous decision to reject the resolution, but the chair did vote in at least one other instance of a minimum quorum. The vote was a sore defeat for the Founder. Salt was rubbed into the wound by a resolution moved by Hoge and carried unanimously directing Director Lake to draft an act amendatory to the 1878 act "concerning the duties and powers of the Board of Directors," to be approved by the Directors and submitted to the legislature. ${ }^{25}$ The intention of the Board was doubtless twofold: to strengthen the Board's powers vis-à-vis the "Regents' power-play, and to counteract by better statutory definition the Supreme Court's narrow interpretation in Foltz v. Hoge et al. of sect. 11 of the 1878 act as to the Directors' powers to manage "all the business of the Col- 
lege." The Board interpreted sect. 11 as not derogating from the Directors' powers, only as denying them compensation for their services.

In the event, nothing appears to have come of Lake's efforts. The next battle to be fought via legislative enactment was at Serranus Clinton Hastings' behest and to the end of accomplishing by legislation the integration with the University that the Hastings Board would not effect. Behind the amendatory act signed into law on March 3, 1883, was a long and bitter division between the Founder and Board that began with the December 22, 1879 meeting and grew steadily worse. In 1880 , the Board delivered a number of slights to the Founder-dean, whether intentionally or not cannot be known. The Registrar and Prof. Pomeroy-the dean was not included-were ordered to set examination days and arrange for the Directors to administer the May finals. When Hastings had concluded an arduous round of negotiations with the University for the lease of a lecture-hall on Front Street, San Francisco, the Board found it "unsuitable" and rejected the lease proposed by the dean. The chair in Comparative Jurisprudence, created in October 1880, and conferred on the dean, who was to serve in it without compensation, might have been less an honor than an indication that the dean was reduced to the status of a mere faculty member. In 1881, Pomeroy was made virtually autonomous, free of the dean's control: he set his own lecture hours, reported directly to the Board on the state of the College, and even undertook to request the Board to convene. When, in March 1881, the Board floated its own "affiliation agreement" (a bald reassertion of the Board's autonomy under the 1878 act which added nothing to it and constituted no concessions, save that the "agreement" could be cancelled by "mutual consent" at any time or unilaterally by either party upon twelve months' notice), Director Evans was appointed a committee of one to negotiate with the Regents, and Pomeroy and the Directors generally were requested to 
assist him. ${ }^{26}$ There was no mention made of Serranus Clinton Hastings. The appointment by the Board of Robert Paul Hastings, LL.B. 1881, son of the Founder, to be Director in the place of Delos Lake, who resigned in August 1881, might be taken as an obeisance to the Founder. It was certainly in line with the Regents' affiliation resolution that would accord a seat to the Founder's heir without subjecting his appointment to the Regents' approval. There is another interpretation possible: though the Board had rejected the Regents' resolution, it chose the simpler path of picking a Director acceptable to everyone rather than a Director-at-large, which might have precipitated a confrontation with the Regents.

At one of the rare Board meetings that he attended in these years, on September 4, 1882, the Founder read his "Definition for 1882." "2 It was a sharp attack on the Board's failings in living up to the terms of the Founder's benefaction, and it was a bitter document: "The living Founder the true altruist is involved in wicked antagonisms for causes not necessary to mention." While he might deny any personal grievances, and generously admitted that in its four years the College had been "successful beyond the anticipations of the Founder," Hastings had an ax to grind. Citing the Elizabethan Statute of Charitable Uses (1601) as providing the definition of "charities" applicable to Hastings, the Founder noted that in English law the Founder, his heirs, or for want of them, the Crown, had the right of visitation for redress of misemployment of the trust or shortcomings of the trustees. He raised the eminent leading English case of the nineteenth century over Harrow School, Attorney-General $v$. the Earl of Clarendon, ${ }^{28}$ decided by the Master of the Rolls in Chancery in 1810, as defining this visitorial power, and noted that he, as Founder, had provided that one of the descendants should always be one of the Directors. Alluding to Robert P. Hastings as a present Director, he called him "one of the special visitors," rather plaintively re- 
flected how the English cases exhibited generous consideration for a founder's intentions, and found a "lamentable contrast" to this generosity in "Republican America." His specific complaints were directed at the failure to provide for a regular course of lectures in legal ethics and lectures in medical jurisprudence; erosion of the sole responsibility of the one professor for the legal teaching (a repudiation of the use of one of the Directors, Oliver Perry Evans, as "assistant professor" at a salary that Hastings obviously thought excessive); and the failure of the Board to enable the Registrar to provide for adequate housing of the College's records. He restated the purposes of the College almost verbatim as he had expressed them at the Berkeley commencement in 1878 when he announced the foundation of the College. He taxed the state with not having provided suitable lecture halls, citing this as a violation of its obligation in having accepted his gift. He reaffirmed his belief that the Directors should have the "government" of the College, and that the University's "denomination" of the College should extend only so far as an act of the faculty of the College was deemed detrimental to the "welfare of the University." The Founder's "Definition," duly entered in the minutes of the Board, and apparently as quickly ignored, was a last plea to the Directors to heed the Founder's wishes. Serranus Clinton Hastings had already sought, or shortly would seek another means to remedy his grievance against the Board.

Immediately preceding the entry in the minutes of the "Definition for 1882" is a copy of the draft bill that would become Stats. 1883, chap. 20, signed into law March 3, 1883, amending the 1878 act. ${ }^{29}$ The Senate Committee on Education introduced S.B. 355 on February 16, 1883; the Senate ordered it placed on file. The bill was given its second and third readings on the same day, February 17 (the three-day rule being waived by a vote of 31-2 on the grounds that it was a "case of urgency"), carrying by $33-1$ and $34-0$, respectively. It was in the assembly on February 28, passed shortly 
thereafter without having been sent to committee, and became law with the governor's signature on March 3 . By the amending act, the officers of the College would be the dean and Registrar, and "The Regents of the University shall have the same control of the College as they possess over the academic department of the University of California, except as hereinafter provided." The provisions in fact do not substantially distinguish Hastings from any other University department. To the Regents redounded a number of privileges and duties: to grant diplomas on the recommendation of the Dean and Faculty and to appoint the Registrar after the death or resignation of the incumbent (Charles P. Hastings); to receive any donations of $\$ 30,000$ for the founding of new professorships; to be paid the annual interest of 7 percent on the original gift of $\$ 100,000$ (as the Board of Directors was previously the payee); and not to expend any part of the annuity $(\$ 7000)$ to any other purposes than instruction, save for the Registrar's services, these not to exceed $\$ 600$ per annum. The dean, who was named in the act as Robert P. Hastings, "the son of the Founder," was to be ex officio a member of the University Faculty and to have the right of audience at any Regents' meeting when he would have College business to lay before the Regents. Future deans would be appointed by the "highest appellate Court of the State ..." and the dean should be "one of the male heirs of the founder if deemed capable and competent." In this act, as in the 1878 act, provision for a room or hall at the University and a lecture hall in the City by the San Francisco supervisors was prescribed, and the 1878 act's clause for reversion of the sum of $\$ 100,000$ to the founder, his heirs, or representatives in the event of the nonexistence of the College or the failure of the state to pay the $\$ 7000$ annuity (save if the legislature failed to make the appropriation at any one session only) was reiterated. To remind San Francisco's city fathers of their duty, there was a proviso that there should always be a course of lectures "upon the duties of municipal 
officers in the City and County of San Francisco." Finally, "the Dean, Acting Professors, Lecturers, Readers, and other instructors" were to constitute the Faculty and "Examining Board" (hitherto the Directors had given examinations).

The effect of the amending act was to make the Board of Directors superfluous, though it does not appear to have effected the Board's abolition, for the University Register continued faithfully to list the names of the Directors. The act vested in the Regents of the University all rights, powers, and authority formerly in the Board. The Board ceased functioning. Its last meeting entered in the minutes was that of September 4, 1881. On May 5, 1883, there was entered in the minutes a meeting of the Faculty of Hastings College of the Law, authorizing the dean, Robert P. Hastings, to handle the College's funds. Not until April 25, 1885, is there entered "a special meeting of the Directors," at which Robert P. Hastings resigned as Dean, Joseph W. Winans, Regent of the University, was elected in his place, and Perrie Kewen was elected Registrar to replace Charles P. Hastings, deceased. While no roll of the Directors is given, Directors named as present were R.F. Morrison, Chief Justice, J.P. Hoge, O.P. Evans, T.I. Bergin, T.B. Bishop, and J.R. Sharpstein-most of the original Directors under the 1878 act. The last order of business for the day was a resolution to meet on the last Saturday of each month in the chief justice's chambers.

The old Directors had been moved to a fighting stance by a new essay in legislative interference by the Founder. On February 3, 1885, Assemblyman E.W. Britt of Lake County introduced A.B. 421 to amend the 1883 act in four substantial sections. By the bill, the officers of the College were to be the dean, the Registrar, and three "Trustees," Thomas P. Stoney, Louis T. Haggin, and R. Porter Ashe, all San Francisco attorneys, but not men of the first rank in the profession. In the future, the trustees would be appointed by the chief justice, with the consent of the remaining trustees. The 
chief justice was to be the president (ex officio) of the trustees, responsible for drawing the funds of the College provided by the state, the trustees concurring; in his absence, or if the chief justice "refuses or neglects to act," the trustees were to appoint one of their number to draw the funds. The Regents of the University were again affirmed in their control over the College as over "the academic department" of the University, subject to the exceptions specified in the act. The purpose of the College was expressed in the same terms as in the 1883 act, but to the lectures on municipal duties were added lectures-perhaps pointed at the old Directors-"upon legal ethics and morality in business." Tuition was to be free. The $\$ 7000$ annuity was to be paid in two semiannual installments, but not to the Directors, as had been specified in the 1878 act. A.B. 421 received its third reading only three days after its introduction. It was amended on the floor to go into effect immediately, and passed by 56-1. The bill's passage through the senate, which amended it, was less smooth, but it was signed into law by the governor on March $18,1885 .^{30}$

The 1883 act had given to the Regents of the University the power they had sought-and which Serranus Clinton Hastings had encouraged them to seek-in the Regents' resolution of affiliation of 1879 . The 1885 act was meant to cure one defect in the 1883 act. The Regents were uncomfortable with the 1883 act's vesting in them responsibility for the property of the College, rather than in a separate corporate entity, as had been prescribed for an "affiliating" institution in the 1868 University act. Thus, while the 1883 act had accomplished "integration" and "incorporation" of Hastings with the University, it had not accomplished "affiliation" because the affiliating corporate entity had disappeared by virtue of the act. Affiliation was important to the Regents, because from the outset they had distinguished between a free-gift and an affiliating institution; in the case of the former, policy and law dictated that a free-gift could not be hedged by power of rever- 
sion. The 1883 act might have proven a bad precedent on this score, but by vesting the property of the College in the "Trustees," the 1885 act cured the defect by recreating the affiliating entity. The "Trustees" were meant to be strawmen, mere receivers of the state annuity and fiduciary donees for subsequent gifts to the College, without responsibility for the functioning of the College.

If the 1883 act was somewhat defective, the 1885 act was badly flawed, as the act itself recognized by providing an alternative in the event the chief justice did not cooperate. The chasm that had opened between the Founder and his Directors, regardless of how blame might be apportioned, had worked the destruction of the old, complex, anomalous, but still workable structure of the 1878 act. The University now had authority at law over an institution it did not quite know what to do with. The institution continued to function, largely autonomously, thanks to the drive and capacity of its professor, John Norton Pomeroy. The acts of 1883 and 1885 produced an impasse in the exercise of responsibility and powers that really did not affect function. The Regents, realizing that they were caught in a battle between two adversaries in which the University had nothing to gain in a victory for either side (and probably not much to lose, either), retired to a neutral corner. The old Directors, finally stung to action by the challenge posed by the second act's spurious "Trustees," came out fighting for a final showdown with an imperious and interfering Founder, even if he was one they had injured and insulted.

The old Directors had waited until death took the Registrar, Charles P. Hastings. They had apparently persuaded the Founder's son Robert, graduate of the first class and a Director from 1881 to 1883 , to throw in his lot with them, probably by persuading him that it was in the interests of the College to do so. Robert Hastings' resignation of the deanship, which had been con- 


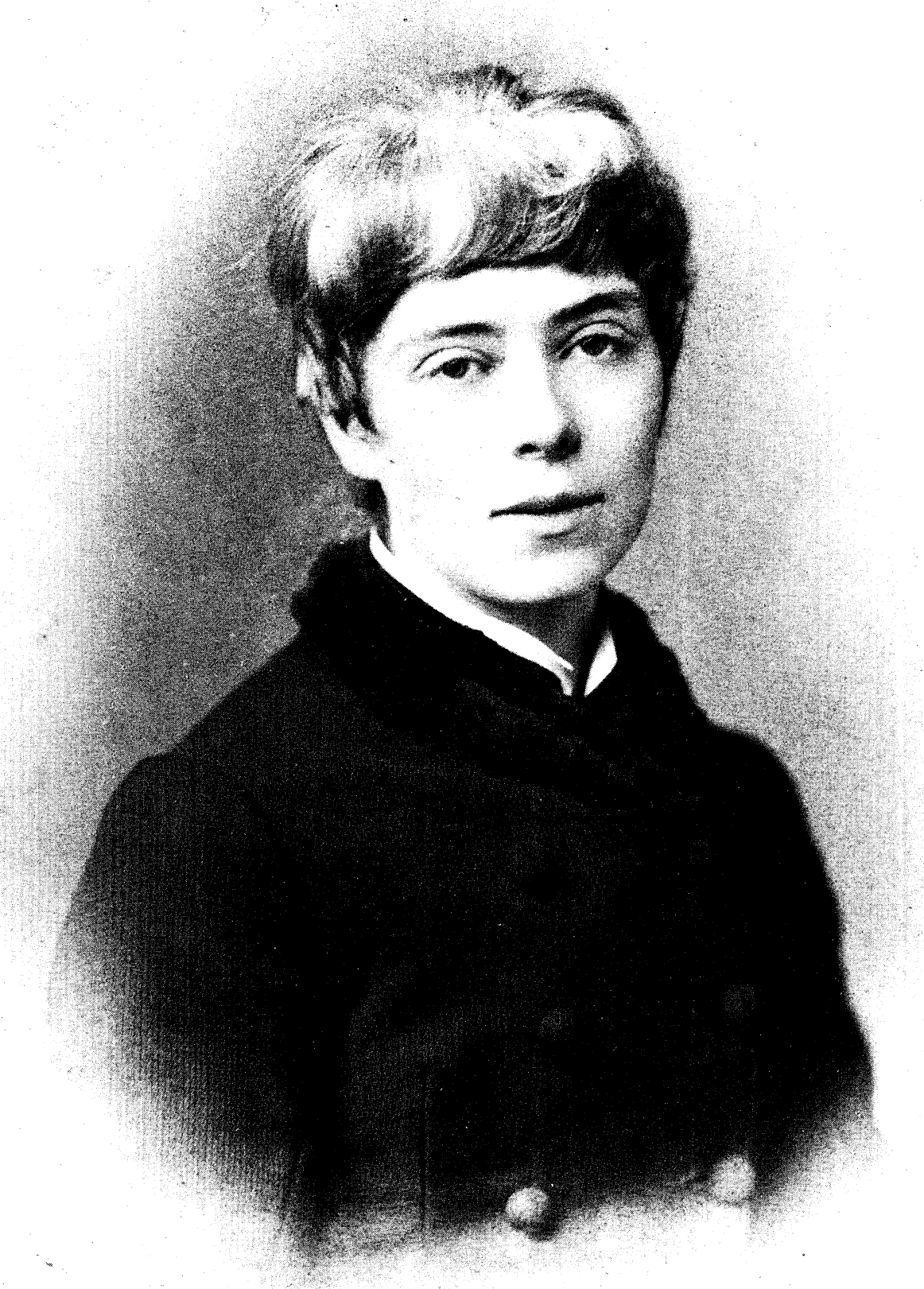

Mary McHenry Keith (Courtesy of the Bancroft Library) 
ferred upon him by the 1883 act, left open the reassertion of the Directors' claim as the rightful authority over the College pursuant to the 1878 act. That was the significance of the meeting of April 25, 1885. The appointment as dean of the noted lawyer, man of culture, bibliophile-and Regent of the University-Joseph Winans, signalled the University's neutrality. It also placed in the deanship the most stalwart fighter for the University's independence from political influence, the delegate to the Constitutional Convention who had led the struggle to put art. 9, sect. 9 in the Constitution of 1879 - the provision which the Directors realized must be the basis of their case against the 1883 and 1885 acts when the matter came to the courts. The Directors enjoyed the full cooperation of Chief Justice R.F. Morrison, a shrewd and fearless man, who as district judge in San Francisco had found for Foltz and Gordon at first instance in 1879. By their appointment of Perrie Kewen as Registrar-an action pursuant to their powers under the 1878 act-the Directors grasped the initiative and challenged the Founder to oust them by law in the assertion of the validity of the 1883 and 1885 acts.

The Founder took up the challenge. Attorney General Edward C. Marshall, on the relation of Serranus Clinton Hastings, brought a quo warranto action in the Superior Court of San Francisco to remove Perrie Kewen as Registrar. The first round in the People etc., ex.rel. S.C. Hastings v. Perrie Kewen went to the Founder. ${ }^{31}$ Kewen appealed, and the case came to hearing in the supreme court in March 1886. Counsel appearing for Kewen were Directors Hoge, Wilson, Evans, Bishop, Bergin, and Ralph C. Harrison (a Director since 1883). The issue turned on the constitutionality of the 1883 and 1885 acts, the Directors having acted pursuant to the 1878 act, which was lawful only if the later acts were invalid. Justice Myrick accepted (uncritically) the contention in the judgment in Foltz v. Hoge et al. that Hastings had affiliated with the University"and had become 
an integral part thereof, subject to the same general provisions of the law as were applicable to the university." Consequently, by art. 9 , sect. 9 of the Constitution of 1879 , "it was not competent for the legislature ... to change the form of the government of the university or of any college thereof then existing" by act in 1883 and 1885 . He held that it was intended by the Constitution to prohibit such changes in the structure of the University as those worked in the transfer of control from Directors to Regents (1883) and to the Trustees (1885), "and if the college is a portion of the university, such prohibition would extend to it." The appointment of Kewen was legal. Justices Thornton and McKee concurred with Myrick. Justice Elisha W. McKinstry concurred, but in a separate opinion took it "for granted" that prior to the adoption of the Constitution of 1879 Hastings had affiliated with the University, and that therefore such attempted changes were prohibited by art. 9, sect. 9. However, "In saying this I neither take judicial notice of an affiliation, nor hold that the fact is, for all purposes, determined by Foltz v. Hoge, 54 Cal:28; but rest my concurrence upon the failure of the complaint to aver that such affiliation had taken place, and upon averments in the complaint which assume it,..." as well as on express claims of the People's counsel. McKinstry (who in 1888 would end his term on the bench and immediately thereupon become Professor of Municipal Law at Hastings) was on firm ground in doubting that the "affiliation" had been accomplished. Chief Justice Morrison properly took no part in the case. The judgment was filed March 30, 1886.

The Directors' victory was complete. Kewen's Case was not, however, lacking in irony. The Constitutional safeguards against political interference in the University had been construed to prevent the legislature from perfecting the affiliation of Hastings with the University that had been intended by the original act of creation of 1878. The affiliation had not, either in fact or convincingly in law, been accomplished. The effect of the 
judgment in Kewen's Case was to freeze an imperfect relationship and an anomalous structure on both the University and Hastings from that day to this. What might have been a real "marriage" was doomed to be a "common law marriage" (almost literally)! Yet, for almost a century, despite some dreadful rows, the odd couple has lived together in relatively mutual sustainment. Not bad as such relationships go.

Kewen's Case was the last hurrah of Serranus Clinton Hastings. Just two days after the judgment was filed, the Directors, with unaccustomed graciousness, invited the Founder to "make whatever statement he desired." The Founder:

Remarked, that it was his earnest desire that there should be a Library attached to the College. That the Librarian should act without salary. Suggested that the Registrar would be the proper person to act in such capacity. ${ }^{32}$

The frugal note was characteristic. Registrar Kewen volunteered. Dean Winans indicated that due to the pressure upon his time he was unable to perform his duties. Registrar Kewen again volunteered and was made acting dean. The Founder's only consolation would have been the appointment of the Rev. Dr. J.H.C. Bonté, Secretary to the Regents of the University, as Professor of Legal Ethics, marking both a reaffirmation of the Founder's wishes for emphasis on legal ethics and in Bontés own person a closer relationship with the University.

Serranus Clinton Hastings, while still technically Professor of Comparative Jurisprudence, had little to do with the College for the last seven years of his life. He did not teach. He made occasional sallies into the affairs of his beloved foundation, in 1887 and 1888, in communications to the Board duly "placed on file." There is no indication that the Directors paid any more heed to them than that. Perhaps some of the old anger stirred in the Founder when the Directors in February 1888 discharged the committee of one (Director Evans) appointed seven years before ostensibly to negotiate 
affiliation with the Regents; consensual affiliation received its quietus. Hastings did have the satisfaction of seeing Robert return to the Board (c. 1885) and become dean again on Winans' death in early 1887 . Robert predeceased his father by some two years, a sore blow to the old man. There were other consolations-and tribulations. Hastings' first wife, Azalea Brodt, whom he had married in Iowa and who bore his eight children, had died in France in 1876. In 1885, Hastings in his seventy-first year married a woman considerably his junior, the fiery Lillian Knust. The marriage was stormy, and he divorced her five years later, only to remarry her shortly before his death. The Founder spent almost all of the last seven years of his life at his home in Napa County. Orrin Kip McMurray, '93, later dean of Boalt Hall, looked back from the vantage point of some forty years and remarked:

Though I was a student at Hastings for the three years between 1890 and 1893 [the year of Hastings' death], I never saw Judge Hastings, nor do I remember that any of my fellow students ever spoke of having seen him. He was a leader belonging to a past generation. He had long withdrawn from the turmoil of life, and had become, at least in our minds, a symbol of a rapidly vanishing race of giants, the pioneers of the golden days of $1849 .^{33}$

That epitaph cannot be improved upon. All that can be added is that in those early years of the College, when Serranus Clinton Hastings' life was indeed a "turmoil," he was no less the giant in fighting, perhaps too stubbornly and even unwisely, for a vision of legal education that was, thanks to his singleness of purpose, not despite it, better realized than he was able to appreciate. Always the man of action, not the reflective scholar, Serranus Clinton Hastings never allowed himself the luxury of stepping back a pace, resting a moment, and surveying his handiwork with pleasure, pride, and demission. He had never learned, as Louis XIV's Marshal Vauban taught, that the prudence which knows when to retreat and to cede to circumstances is one of the forms of the 
art of governing. It was, though, his unceasing striving and his restlessness that made Serranus Clinton Hastings the giant that he was.

Serranus Clinton Hastings died on February 18, 1893 , in his seventy-ninth year. On his tombstone in the old family plot in the St. Helena Public Cemetery are inscribed the words, First Chief Justice of the State of California and Founder of the Hastings College of the Law. 


\section{IIII Pomeroy \\ and Slack}

$\prod_{\text {He }}$ First two decades of Hastings College of the Law were dominated by two men, both teachers, who were responsible for instruction. One had been master, the other pupil. One had a reputation before he came to the College that placed him in the front rank of legal scholars and teachers in the entire country, a jurisperitus whose large corpus of writings won acclaim and a notice from Chief Justice Salmon P. Chase that his works had direct influence on the Supreme Court of the United States. The other had been a college senior in mechanical engineering at Berkeley when his future master met the first class at Hastings, and while he attained great local recognition throughout a long career in law as educator, counsel, and judge, and for his public service, he was never a national figure. Neither was he a scholar in the technical, academic sense of the word. Together, though, John Norton Pomeroy and Charles William Slack brought to Hastings genuine academic distinction and sustained that distinction so that in the less favorable epoch that succeeded theirs, Hastings' reputation was rightly maintained. While it is an accepted convention that Pomeroy was the great creator at Hastings, Slack deserves much more attention than he has been given. Without Slack, Pomeroy's work would probably have been undone in a season. Thanks 
to Slack, the Pomeroy System remained vital, and even influential in varying degrees, until new trends in legal education in particular, and in the law in general, dictated largescale change. It remains an open question whether the new approaches to legal education were better than the old system.

To anyone familiar with the evolution of educational method at Harvard Law School at about the time that Pomeroy and Slack dominated Hastings, the names Christopher Columbus Langdell and James Barr Ames will command instant recognition. The parallels between Langdell/Ames and Pomeroy/Slack are remarkable, both in the relationship of each pair, and in the parallel development of their methods, similar in so many ways though the men and their institutions were divided by a continent. The Harvard brace is more famous; by virtue of being at Harvard, it was certainly more influential. But the work of the Hastings brace has more than mere curiosity or local color about it. Pomeroy and Slack provided an approach to learning the law that made more sense in those jurisdictionsparticularly in the West-which had gone a long way towards codification, towards systematization of the law by a rational structure of legislation, wherein the teaching of law might benefit more from a pedagogic system than from merely a pedagogic method. As the dean of American legal historians, Willard Hurst, pointed out, though Pomeroy's approach:

was radically different from the prevailing text-and-lecture method ... it did not fall to him to shape the whole program of a leading school to a new technique, and thence both to redirect and to warp the course of law training in the United States. ${ }^{1}$

Langdell/Ames did so shape-and did so warp-American legal education.

By any contemporary reckoning, John Norton Pomeroy (pronounced Pum-roy) was one of ten top law teachers in late nineteenth century America, ranking with Langdell and Ames (Harvard), Theodore Timothy 
Dwight (Columbia), William Gardiner Hammond (Iowa and Washington University, St. Louis), Thomas McIntyre Cooley (Michigan), Theodore Salisbury Woolsey (Yale), and two or three others of like stature. These were the first generation of academic teacher-scholars in the law who were the creators of the modern American law school. They were all committed to the proposition that the law was a "science" and that it must be investigated and analyzed by the intellectually rigorous methods of the physical sciences. As Langdell put it, "Law is a science; ... all the available materials of that science are contained in printed books ... the library is the proper workshop of professors and students alike ... to us, all that the laboratories of the university are to the chemists and physicists...."2 This positivism or scientism was an article of faith, not by mere imitation of the increasingly rapid expansion of physical science in the latter half of the century, but by these scholars' conviction that they must master the whole of the law and adapt the "ancient" rules of the law to new political, economic, social, and intellectual realities. Pomeroy, in rejecting traditional ways of categorizing and analyzing equity by the external factual situations giving rise to equitable rules, exploded:

A jurisprudence, however, does not consist of the mere facts or events which are the occasions of rules and rights, but of the rules which create the rights, and of the rights and duties themselves which result from these rules. ${ }^{3}$

This was not a blind positivism; Pomeroy felt constrained to breach a pure scientific methodology in his own arrangement of equity in order to avoid repetition in his exposition. When applied to teaching the law, Pomeroy recognized the problems rigid scientism raised. He informed his first class at Hastings that "the whole course will be truly scientific in its classification and arrangement of subjects, but practical in its modes of study and work by the classes themselves." Indeed, classification is the key to understanding both Pome- 
roy's scholarship and his pedagogical system which found its final expression in the curriculum at Hastings.

Pomeroy was distinguished from his equally distinguished peers in two ways. One was in the sheer bulk of his published scholarship and the extraordinary range and diversity of his writings. The other was in the conceptual boldness with which he was prepared to tackle the law. To give full attention to the first would require a bibliography so long as to constitute an appendix. Following his lead, we can best assess the amount and scope of his corpus by "classification and arrangement." Between 1864 and the last year of his life, 1885, he published two basic texts (virtually treatises); four major treatises; two editions of English treatises; two major articles on criminal procedure, six articles on international law and nine short essays on the same, eleven on constitutional law, two on the Civil Code and community property; and a number of miscellaneous works, including the syllabi for his second-year courses at Hastings, numerous reviews, and an introduction to the memoirs of Stephen J. Field. The two texts, which were his earliest work, were Introduction to Municipal Law (1864), on the entire range of law, a jurisprudential, historical, and comparative study, and An Introduction to the Constitutional Law of the United States (1868), one of the earliest theoretical expositions of the constitutional law of the United States. The treatises date from the last decade of his life and indicate a scope that is nearly breathtaking: They include works on remedies and remedial rights, both at common law and in equity, by the civil action according to the reformed American procedure (1876); specific performance of contracts (1879); equity jurisprudence (in his monumental, three-volume A Treatise on Equity Jurisprudence, 1881-83); and riparian rights (1884). He must be credited also with a treatise on international law essayed in lectures, which were edited and published posthumously (1886) by Woolsey. Both of the works Pomeroy himself edited, Sedgwick's Rules of Interpretation and Construction of Statutory and Constitu- 
tional Law (1874) and Archbold's Criminal Procedure, Pleading, and Evidence (1877), date from the somewhat unhappy years between New York University and Hastings, when Pomeroy survived by writing. If hackwork, they are nevertheless splendidly executed adaptations of English learning to American use by a lively intellect. The range of his articles, most of them intended for popular consumption, for a literate lay readership, speaks for itself. The two efforts on peculiarities of California law were very important. The "Civil Code" articles, which first appeared in the West Coast Reporter (a publication he founded and edited with his son Carter) and were afterward printed as a pamphlet, constituted a sharp and well-aimed attack on the more preposterous pretensions of the California code to authoritative finality. It was taken up with fervor in New York, and contributed to the defeat of the referendum there which would have adopted the code in New York. More importantly, Pomeroy enunciated the (strict and narrow) rule of interpretation which the California courts generally have applied to the Civil Code. Pomeroy's article on community property was the first nationally read treatment on that remarkable institution of California law.

If none of his eminent contemporaries could claim such a large corpus of scholarship on such a wide range of subjects addressed to professional, student, and intelligent lay audiences, neither did any of them demonstrate quite the conceptual originality that was Pomeroy's particular gift. To a large extent this originality grew from the imaginative perception of a need and the filling of it. The book on remedies and remedial rights constituted a wholly new approach to civil procedure, founded on the recognition that David Dudley Field's civil procedure code for New York begged for a jurisprudential foundation and a close logical analysis that would enable the lawyer to give it effect with real vigor in practice. Pomeroy argued that with the forms of action dead in all those jurisdictions which accepted (and 
were accepting) the reformed procedure, remedies constituted fundamental attributes of the new system, and it was an error to treat procedure as if indeed, in Frederick William Maitland's phrase, "the forms of action rule us from the grave." The treatise on specific performance of contracts accepted the burden of the English judicial reform of the 1870s (though Pomeroy failed to credit how far English legal conservatism would preserve the distinction in practice and forum between "common law" and "equity") and appreciated the extent to which American practice had always blurred, and with the reformed procedure would blur even more, the law-equity distinction. Pomeroy was not a profound researcher. His works are not monuments to the careful acquisition of unknown data, but rather brilliant syntheses founded upon readily available facts, fashioned by a quick intellect of unusual conceptual powers.

Perception of need was a major element in the impetus for the Introduction to the Constitutional Law of the United States. Pomeroy's learned son would note ruefully that its appearance in 1868 came at the wrong time, at the beginning of an extraordinary era of constitutional change which made its case-law obsolete in literally a matter of months. But its purpose was to provide a direction for the profession and the courts-and beyond them, the nation-to regain a basis for establishing equilibrium in the aftermath of the constitutionally most destructive epoch in the nation's history. The principal issue of that epoch was the nature of the federal union, whether it was an agglomeration of states or a nation. Pomeroy understood that while the union had been preserved, the nation might have disappeared, or might still disappear. This fear drove him to origins, searching the Continental jurists for fundamental conceptions of "sovereignty," the "state," and "government." He concluded that the United States was a nation, that the Constitution was not a contract between sovereignties, but the highest articulation of the will of a sovereign nation 
that had come into existence before the states. This "nationalism" was something more than "federalism." It needed expressing as the nation crawled away from Appomattox and plunged into radical Reconstruction. The theoretical-historical-comparative dimension of the book is timeless, even where subsequent knowledge supersedes it. Just as the cases cited tumbled, so did the author's own apprehension of "nationalism" undergo change, as he came to fear the judicial activism that appeared to be eroding the functions of the states. Perhaps he did become, as one scholar believes, a "state rights nationalist." 4 Pomeroy's book was a brilliant tract for the times, with a scholarship and intellectual substance that have endured. The constitutional law work demonstrates something more, though, than a mere perception of need: There "was a strong trait of political awareness in Pomeroy, a sense of mission, a crusading zeal for legal goodness and probity. The articles on constitutional law, especially the nine major pieces in The Nation, 1870-76, give point to this. While these commentaries on current Supreme Court interpretations of the Constitution during Reconstruction (amnesty, the Force Bill, citizens' rights in the South, theory of nationality, North Carolina's constitutional agonies post Civil War) and in the first stages of assertive legal-nationalism (civil service reform, railway regulation) were updates of the constitutional law treatise, they were also vigorous, sometimes intemperate, exercises in molding public opinion.

Need and mission are best evidenced in the two works which were his most original, most brilliantly argued, best written, longest enduring, the first and nearly the last of his career, An Introduction to Municipal Law and the three-volume $A$ Treatise on Equity Jurisprudence. Municipal Law was avowedly for "general readers, and for students in colleges and higher schools." 5 The title is arresting (it has nothing to do with "municipal corporations" as some cataloguers suppose). By "municipal" Pomeroy meant the whole body of man- 
made, human, positive law of a sovereign entity, of the "state." The word connotes comprehensiveness and, for one who would use it descriptively of his work, ambitiousness. It was no accident that Pomeroy's chair at Hastings was the Professorship of Municipal Law; no accident that it would be filled by his two immediate successors for a season, after which the "Municipal" was quietly dropped. Pomeroy claimed to command the whole body of the nation's law, and the range of his scholarship and his teachings gave him better title than most to "municipal." The book, something over 500 pages, sets out a jurisprudential definition of law, the law in terms of means, methods, and forms of development (statutes, unwritten law, courts, adjective law); historical origins of English and American law, including Roman Law (ancient, medieval) and maritime codes of the middle ages; and concludes with an "outline" of American law on the basis of its English origins, divided by persons, property, and contracts, and the rights pertaining under each. The book is remarkable. Even under those title-sections, which are Anglo-American, Roman learning and Continental practice are interwoven to make a complete explanation of the law's development. Roman Law receives detailed attention that is both admirable and admiring. Pomeroy demonstrated, albeit not very convincingly in the light of later scholarship, heavy Roman influence on medieval English law. Decades later, he would note with satisfaction that much of California's property law was closer to Roman than to common law principles. Municipal Law bears witness to all of Pomeroy's jurisprudential axioms: law is a science, compounded of ethics and history and therefore understandable only in the broadest historical context of human aspiration, yet it receives form and frame only in the realities of a nation's own experience of its needs; while codification can provide a more rational structure of law, its limitations demand the maintenance of the law of judicial decision as that best suited to a high level of civilization and a progressive people. Pomeroy 
modestly offered the book as a preparation for Blackstone or Kent; in fact it is a substitute for either, more broadly based, more persuasive, more stimulating, and much more up-to-date to the American experience at midcentury. Moreover, Pomeroy's originality shows to good advantage here; his two eminent contemporaries, Cooley and Hammond (both of whom were invited to Hastings to fill Pomeroy's chair, but declined), never undertook anything so ambitious, resting satisfied with new editions of Blackstone which were at least scholarly, unlike the bulk of the editions that glutted the market. Pomeroy made no claim "to any originality of historical investigation," but "municipal" law had never before or has it since received such panoramic treatment. A legal historian finds the book still very much worth reading.

The Treatise on Equity Jurisprudence, as Administered in the United States, Adapted for all the States, and to the Union of Legal and Equitable Remedies under the Reformed Procedure (this shortened title is perfectly descriptive of the objective and the scope of the work) was conceived on a grand scale and not entirely executed. Pomeroy did see it all into print, but the pressure of work and other projects caused him to foreshorten considerably the part that he had envisaged as the largest- "remedial rights and duties enforced by the various remedies it confers." By the time he had completed his survey of the nature and extent of equity jurisdiction in the United States (Part I) and launched his treatment of the "grand principles and maxims of equity jurisprudence" (Part II) in volume one, he decided to treat the "primary rights and duties" (equitable estates, titles, and interests) immediately after Part II, in volume two, reversing his original order so that it became Part III, and the remedial section became Part IV. The change in priorities came with Pomeroy's conviction that he had something unique to offer in the emphasis on primary rights and duties, remedial rights and duties having too long dominated the study of equity. The choice proved sound; 
the most innovative part, Part III, was fully laid out before his death (two years after publication of the last volume-three-in 1883) prevented the fullness of remedial coverage he had hoped for.

Equity Jurisprudence was a crusading effort. Recognizing that the reformed procedure abolished the distinction between common law and equity actions, Pomeroy prophesied that the ultimate result would not be to increase equitable influence in the law but to erode equitable notions by more rigid legal doctrines. He cited with misgiving the experience of the states with reformed procedure: "In short, the principles, doctrines, and rules of equity are certainly disappearing from the municipal law of a large number of the States, and this deterioration will go on until it is checked either by a legislative enactment, or by a general revival of the study of equity throughout the ranks of the legal profession."6 This work was to be his contribution to the latter solution. To accomplish the "general revival," Pomeroy realized that something more must be done than merely trotting out the same old tired maxims, and certainly much more than treating equity as a matter of jurisdiction. The reformed procedure destroyed jurisdiction as a basis for equitable rules; no longer did a classification of exclusive jurisdiction, concurrent jurisdiction, auxiliary jurisdiction, make any sense. An over-emphasis on remedies was equally disastrous, because equity was not merely a matter of solutions, but a body of principles. Pomeroy sought a system of classification that was comprehensive and conformable to the realities of American practice, one that would present all of the components in true relationship to each other and to the law, represent true lines of distinction between the components, and serve as a correct and practical guide for the student and lawyer, so that they could master the "essence" of equity and thereby make the acquisition of its rules "an easy and delightful labor." (This last was a patently impossible objective!) The classification adopted was that set out above, with 
the remedial rights and duties based not on jurisdictional notions, but on an understanding of their own inherent nature and the nature of the primary rights, the violation of which they are intended to redress or relieve. The primary rights and duties were, for Pomeroy, the essence of equity.

Equity Jurisprudence is extraordinarily successful in its effort. It might not manage to make learning equity easy and delightful, but followed in its rationalized structure it makes equity seem to be a system. Here, of course, was its danger; equity was not then, or is it now, quite that systemic. Approaching Pomeroy's book from a training in modern English equity is an humbling and unnerving experience. It is humbling because Pomeroy made equity manageable as a subject (if not quite a system) in a way that eluded many English scholars of great eminence during the last century. It is unnerving because Pomeroy, while using equity in a technically entirely correct way, accorded it a goodness and righteousness that has always been at best questionable and is today irrelevant:

I need not dwell upon the disastrous consequences of the tendency above described [erosion of equity], if it should go on to its final stage. Even a partial loss of equity would be a fatal injury to the jurisprudence of a State. So far as equitable rules differ from those of the law, they are confessedly more just and righteous, and their disappearance would be a long step backward in the progress of civilization. ${ }^{7}$

Even allowing for hyperbole sprung from advocacy, this is excessive. Still, Pomeroy's fears were not entirely illfounded. Equity as an entity capable of being taught in the American law school has disappeared, its elements scattered over a good many courses. Equitable doctrines and notions have survived, and Pomeroy appears to have contributed much to that survival. A 1903 survey indicated that Equity Jurisprudence was one of the fifty texts most often cited in courts at that time. The date was portentous: it opened the decade of greatest change in the nature of law and of legal education in America. 
That the substance of equity did not disappear might well have owed something to Pomeroy's restatement of it at the eleventh hour.

John Norton Pomeroy was preeminently a pedagogue. Though the son of a probate judge in Rochester, New York, he showed no early inclination to the law. On graduating in 1847 from Hamilton College, where he received a Classical education, he spent some three years schoolmastering, first in Rochester and then near Cincinnati, where he turned to the law only because he hoped for a better income than teaching provided. He completed his law-office study on his return to Rochester, and was admitted in New York in 1851. His financial need increased when he married an old pupil in 1855, who bore him a son the next year. He was hardworking and frugal, a product of a long line of eminent Presbyterians, parsons and laymen, and the puritan work ethic of his own background was not at all diminished by his marriage to Ann Rebecca Carter of Savannah, who converted him to a broad church Episcopalianism. Alas, he did not prosper in ten years at the bar. A merciful veil screens these years, with but a few glimpses provided: some fleeting fame in successfully defending a murderer, and a year of daunting hardship trying unsuccessfully to prosper in New York City. He almost epitomized Frederick William Maitland's barrister, who would turn to scholarship while waiting for the client who never comes. In 1861 he went back to teaching at Kingston. Amidst the daily grind of the classroom and spurred on by two more young mouths to feed, he produced Municipal Law in 1864, which brought acclaim, an honorary LL.D. from his alma mater, and an immediate invitation to teach at New York University Law School. The next seven years were spent in his first experience in teaching law. His most eminent student there, Elihu Root, later Secretary of State and the greatest international lawyer America has produced, recalled that Pomeroy was unstinting of his time 
with his handful of students, going with them from dawn to dusk, teaching, talking, criticizing, arguing. His only major scholarly production while at NYU was the Introduction to Constitutional Law, 1868. His intense involvement took its toll on his health, and in 1871 he retired to Rochester to support himself and his family by writing. This was a productive period, albeit one of occasional and popular pieces and edited texts more than of the major works of his last years. He did write the treatise on specific performance of contracts, and he probably laid the foundation in study for his later works. He had the time to read widely and continuously. It was, though, a bare existence. The call to Hastings in 1878 was Gabriel's trumpet.

Pomeroy's failure as a practicing lawyer was the necessary precondition for his success as a scholar and even as a teacher. Again, in this he was distinguished from most of his contemporaries, who had successful practices before and even during their years in law teaching. The hard years of marginal existence were Pomeroy's learning years, even if they were not years of major scholarly production. To write, Pomeroy needed the interchange with persons of intellect, the discourse and intercourse with minds tied to articulate tongues which can be afforded a legal scholar at bar or in the classroom. Not until the end of his career did Pomeroy have a chance to demonstrate his real capacity as a counsel at bar. And it was not for his forensic pyrotechnics that he won his fame; he read his presentation without a benchward glance, in a steady (and possibly hypnotic) voice. But his briefs and his oral arguments in the Railroad Tax Cases, San Mateo County v. Southern Pacific Railroad Co. (1882) and Santa Clara County v. Same (1883), and the famous Debris Case, Woodruff v. North Bloomfield Gravel Mining Co. et al. (1883 and 1884), ${ }^{8}$ were masterpieces that won the admiration of the U.S. Circuit judges who heard these cases involving burning economic and political issues. As Judge Lorenzo Sawyer, referring to the Debris Case, put it, "Like his 
works upon the law, his arguments were always lucid, exhaustive, and eminently instructive-such arguments as courts desire to hear when great interests and great and far-reaching principles are involved."9

In the Railroad Tax Cases, Pomeroy (co-counsel with Hastings Director Bergin and others), appeared for the railroads, arguing that they were exempt from local taxation as instruments of the federal government (by grants, etc., for postal and military purposes), and that the Fourteenth Amendment imposed limitation upon the state's power to impose taxation on the "person," which was the railroad company. The railroads won in the District Court for California, a milestone in the development (perhaps the perversion) of the Fourteenth Amendment, and further encouragement to the rapacity of the railroads, which would shortly bring a strong, popular reaction and the Interstate Commerce Act to begin the hard task of curbing the railroads. Pomeroy might not have been on the side of the angels, but the court held the law to be with him. In the Debris Case, Pomeroy appeared for the plaintiffs, farmers outraged at the destruction of agrarian property by hydraulic-jet mining which tore riverbanks and riverbeds to shreds and deposited the debris on the acres adjoining. The suit was in equity for nuisance. The resulting decision and injunction, recognizing that a single tenant of land in common could bring an action to abate a public and private nuisance, was the death sentence for hydraulic mining here, winning a place in the annals of California legal and economic history (and, one supposes, if they will notice it, deserving of a place in the books of the environmentalists). These cases were very satisfying to Pomeroy. It assured him that his scholarship and his pedagogy were not in vain, that he could do as he taught. Indeed, the carefully reasoned and perfectly arranged arguments were vindications of the Pomeroy System of legal instruction, the triumph of the master using the tools he himself had fashioned.

The Pomeroy System was above all else a systema- 
tic, logical structuring of branches of the law, and further, an increasingly fine and detailed subdividing of each branch. The law, of course, imposed its own categories. But it was the arrangement and relationship of one branch to another, the emphasis on amount of time given to each as against the others that allowed for creative systematization. The classification, then, determined weight (amount of time, emphasis) and depth (degree of detail) accorded to a subject. This was elementary. Yet one suspects from texts used in laternineteenth century law school courses, and from what few materials we have on courses actually taught in some schools, that such elementary classificatory structuring was seldom attempted. Pomeroy was a thoroughgoing taxonomist. As he noted in Municipal Law, the "copious table of contents is intended, not simply as a means of reference, but as a complete analysis of the whole book. ..."10 It certainly is. His preoccupation with classification of the subject in the first hundred pages of Equity Jurisprudence is fundamental to the very substance of equity as he saw it. The entire curriculum at Hastings, the structure of the Pomeroy System, is taxonomic in the extreme.

What system did Pomeroy use to classify subject matter? Essentially, it was the system of Aristotle, with its emphasis on primary and secondary characteristics, as that system was attacked, simplified, and vulgarized by the sixteenth-century French Calvinist logician, Peter Ramus. Pomeroy might well have been familiar with Ramist logic. Ramus' work had been translated into English and was in vogue with seventeenth century English puritan clerics. If Pomeroy had not read Ramus, he had read Serjeant Henry Finch's Nomotechnia (1613), translated and reprinted in 1759 as Law, or a Discourse Thereof, directed at the student. The example below, from one of Pomeroy's tables for the first-year course at Hastings, could easily have come from Finch; though the nomenclature is different, the structure is not. This 
is taken out here to only the fourth division; Pomeroy's table includes two further subdivisions. This, the "Primary" rights and duties, category $\mathrm{I}$, is of course in Pomeroy's scheme matched by "II. Remedial."

Rights and Duties Relating to Things and Transactions as their Object

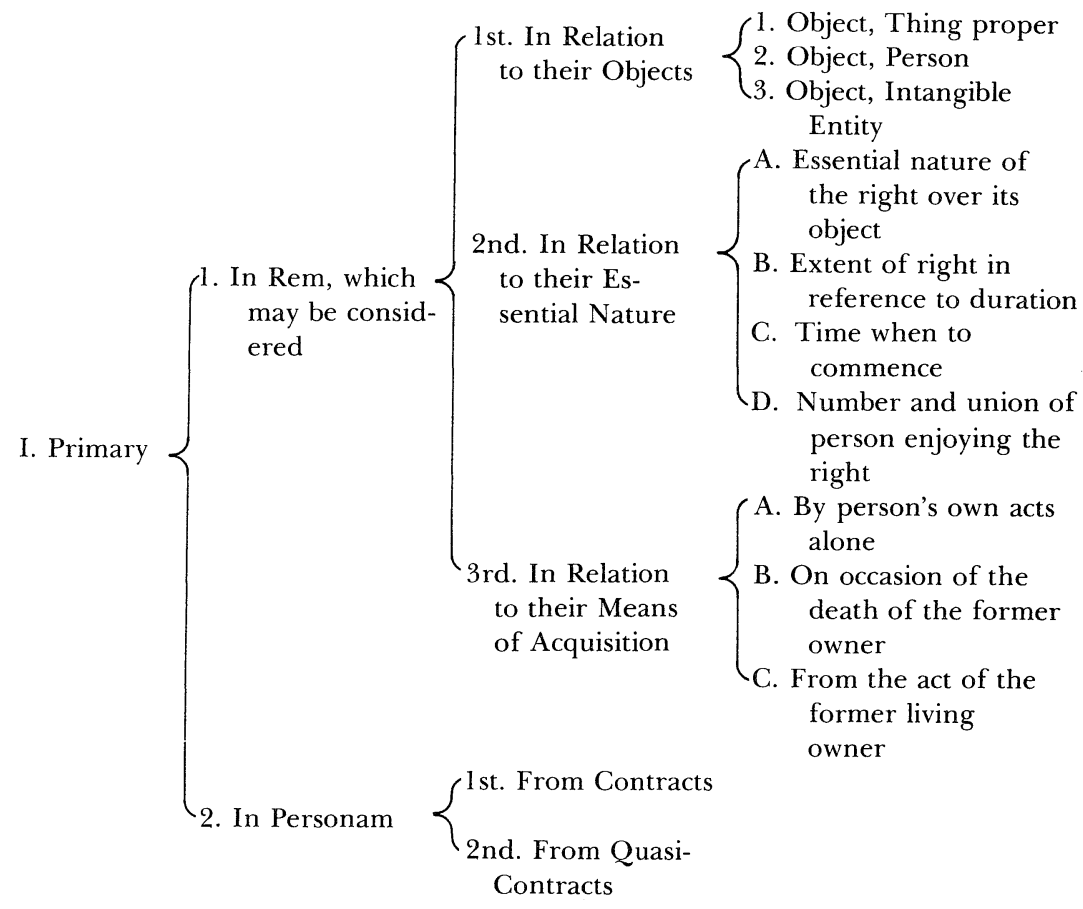

Such impeccable Ramist logic could be applied at every level of curriculum development. The above example was refined, and was intended to drive home Pomeroy's basic distinction between Primary Rights and Duties and Remedial Rights and Duties in every branch of the law. When applied to the entire curriculum at Hastings, the classification resulted in the structure in the table, "The Pomeroy System," reconstructed from early announcements, Pomeroy's Syllabi, and the University Register. 


\section{The Pomeroy System}

Junior [First] Year: Continuous reference to California \& Pacific states statutory law. Lectures, discussions.

First Course: Introductory lectures on nature of law

I. Law as to Persons

II. Law as to Personal Property

III. Law as to Contracts-general doctrines \& principles of mercantile contracts

Second Course: Law as to Real Property-origin \& history, excluding that covered in middle yr.
Four tables of classification; Pomeroy Munic. Law.

Kent Commen. lects 24-32. Collateral reading: personal rights, torts (Bigelow) (Addison) (Hilliard) (Waterman Trespass) (Bigelow Cases); slander \& libel (Townshend) (Starkie) (Smith Cases) (Amer. Ldg. Cases); marriage, divorce, domestic (Bishop Mge. \& Div.) (Schouler) (Reeve) (Bingham) (Parsons Contract) (Bishop Marr. Wom. Prop.) (Smith Cases) (Amer. Ldg. Cases).

Kent Commen. lects. 34-38. Collateral (Williams).

Metcalf Contract; Parsons Contract; Kent Commen. lects. re merc. contracts. Collateral: (Langdell Cases) portions of (Smith) (Chitty) (Story) or (Addison).

Blackstone Comm. Bk. II; Washburn Real Prop. Collateral: (Williams) (Kent Commen. re realty) (Smith Cases) (Washburne Easements) (Jones Mortgages). 
Middle [Second] Year: Lectures \& discussions based upon Syllabi, with collateral reading \& study of cases.

Mercantile \& Commercial Law, full course; corporations, agency, partnership, sales, bailments, bills \& notes, insurance, shipping contracts, surety ship

Real Property (rest of); remainders \& executory devises, uses \& trusts, powers

Wills, Testaments, \& Administration

Equity Jurisprudence (reference to statutes)

Torts
Pomeroy Syllabi; treatises assigned in the Syllabi; leading cases cited in the Syllabi; California statutes.

Senior [Third] Year: Principally lectures; exercises in preparing pleadings, drafting papers \& instruments.

First branch:

Remedies: pleading \& practice per the Reformed System-theory of forms of action; common law \& equity pleading; evidence

Second Branch: Constitutional Law, U.S. \& California International Law, public \& private Roman Law and General Jurisprudence Legal Ethics

Criminal Law
Pomeroy Syllabi; Gould or Stephens Com. Law Pleading; Lubé Equity Pleading; Pomeroy Remedies \& Remedial Rights; Greenleaf Evidence. Collateral to be referred to.

Pomeroy Const. Law; Cooley Consti. Limitations; Wheaton Internat. Law; Wharton Priv. Internat. Law or Story Conflict; Sandars' Instit. Justinian; Maine Ancient Law; Blackstone Commen. Bk. IV; Penal Code of California.

Moot Court open to all the classes for the argument of cases and discussion of legal questions. 
The curriculum contained all of the law requisite for a sound legal education of the day. What was unique was the arrangement of the courses. The first year was given over to introductory material, which in itself was an entire year of classifying the law, largely on the basis of its historical development. Even the "second course," an introduction to real property, is heavily historical; the real property that counts is reserved for the second year. In comparing Pomeroy's System with our present, virtually universal American law school curriculum for the first year, it becomes clear that the System provided everything but criminal law and civil procedure. Unlike our curriculum for the first year, this one is holistic, the parts bearing a functional relationship to each other and thus to the whole, thanks to the arrangement under the categories of persons, property, and obligations (contracts). The categories are a bit forced; they are far too Roman (Justinian's Institutes, Books I, II, III, respectively) to fit snugly an Anglo-American structure born of accident. Yet they constitute a superb introduction to the law, which we no longer even attempt to match. With the second year, the Pomeroy System comes to the LAW in its mass rather than its majesty, the stuff that the practicing attorney would have to deal with every day he went to the office. This is the law that Pomeroy would characterize in gross as Primary Rights and Duties. In the System, the second year was paramount in importance; in our curriculum, we have reversed the paramountcy, shifting it to the first year. The attention to detail, the weight of lectures and discussions, bore down most heavily in the second year. By Pomeroy's reckoning, the third year altogether constituted Remedial Rights and Duties. This is patent in the First Branch, but it is only slightly obscured in the Second. Constitutional law, international law, and conflicts were, from the vantage of a late nineteenth century practitioner, more a matter of "remedial rights" (if that is not taken too narrowly to mean only adjective law) than of "primary rights." The practitioner reasonably 
might expect to have slight concern with these parts of the Second Branch. In criminal law, though he had to be prepared to practice it, the concern was more procedural than substantive (as it still is in the law school curriculum). The more arcane subjects of the Second Branch were to add polish, in fact were heavily "remedial" in supplying the ornament of learning, the rhetorical polish demanded in the forensic art, and the finetuning of that emotional sensitivity which the Victorians called "sentiment," and which was a necessary ingredient in a good courtroom manner. The Pomeroy System is impressive still because it covered all of the law, put the emphases where they were most appropriate, built upon the accumulating mastery that the student built up year by year, and gave to the student a grasp of the whole law that we have since despaired of inculcating. The remedies emphasis of the last year, including practice in drafting, founded upon mastery of the primary law of the second year, launched the fledgling LL.B. into practice with a momentum that we are still trying to emulate with a clinical semester, judicial externships, student-initiated projects, and trial practice courses.

Having given the highly wrought, architectonic structure of the Pomeroy System, it remains to describe its dynamic - how it actually worked. The first and second years called for lectures and discussions; the third year was principally lectures, but with practical workshop exercises in drafting, and probably the bulk of mooting that a student did over the course of the three years. The first-year classroom situation would resemble an upper-division course in history or the social sciences today, with discussion built on a range of assigned reading, but with full allowance for developing naturally as the discussion progressed. Conceptual originality rather than technical rigor was the objective. True to his System, Pomeroy used the statutory law as the frame of the law for the "Junior" students; though he had always expressed doubt as to the virtue of legislative enactment 
and code as being dominant in law, Pomeroy recognized the fundamental attributes of statutes and the convenience of using them to lay out the boundaries of the law. The first year concluded with a set of comprehensive examinations. Unfortunately, we have no example of them, but they might well have been similar to the college essay exam of today, demanding that fact and theory be woven together to provide a total explanation.

The second year was an experience different in kind from the first. The student was plunged into the substantive law, with very little reading in treatises and texts. At least three-quarters of the pre-class preparation was devoted to cases. The Syllabi that Pomeroy prepared, and which were printed and given to the student at the beginning of the course of lectures devoted to the subject in hand, directed the student to work up the cases cited in conjunction with code provisions and collateral reading in texts before attending the relevant lecture. The Syllabi were updated at least every two years to take account of new cases. We have Syllabi for all the second-year subjects save Partnership, Insurance, Shipping Contracts, Powers, Torts, and (unhappily) Equity. From. Mary McHenry's lecture notes of the second-year course we know that Pomeroy adhered to the syllabus in delivering his lectures, expanding on the précis of the subject matter in the syllabus and construing the leading cases which the students had already studied, weighting some more than others. Within each subject, where relevant, the topical organization followed the California Civil Code section by section, with few exceptions. In most subjects the bulk of the cases were drawn, understandably, from California and New York. Each syllabus was some twenty to forty pages long, varying less with the difficulty or intractability of the subject matter than with the number of lectures devoted to the subject. The result was a distinct evenness of treatment. From the existing Syllabi, we can project the number of lectures in the subjects for which we do not have Syllabi: Commercial Law and Real Property; 
and for the whole of Equity, the later student edition of Equity Jurisprudence (edited by John Norton Pomeroy, Jr. and published in 1907) provides a guide in its rational and analytical table of contents as to how Pomeroy Senior might have handled the subject. Mary McHenry's lecture notes fill gaps. The second-year curriculum can be plotted thus (the square brackets indicate suppositional number of lectures):

A. Mercantile and Commercial Law

1. Corporations

2. Agency

10 lectures

3. Partnership

4. Sales

5. Bailments

6. Bills \& Notes (Negot. Instr.)

7. Insurance

8. Shipping Contracts

9. Suretyship

B. Real Property

1. Remainders \& Executory Devises

2. Uses \& Trusts

3. Powers

\begin{tabular}{lc} 
& 4 \\
& 6 \\
Total & {$[8]$} \\
\cline { 2 - 2 } & {$[18]$} \\
Total & 9 \\
Total & {$[74]$} \\
Total & {$[14]$}
\end{tabular}

C. Wills, Testaments, \& Administration

D. Equity Jurisprudence

E. Torts

18] 
pelled to maintain its vitality. That there was "constant reference to statutes" under Equity indicates that it served as a vehicle to instruct in statutory interpretation and jurisdiction. At the end of the second year, another set of comprehensive examinations was set. We have no examples of these, but there is a likelihood, judging by extant examinations for the third year, that the questions were much less factually set than are today's, and yet emphasized statutory and case foundation for the conclusions to be arrived at. They were certainly both searching and comprehensive; Prof. Pomeroy did not give a choice of questions, and the student had to do an essay on each one posed.

The third-year course did not rely on Syllabi. There is one extant Syllabus, entitled "Remedies," which is markedly different from the second year Syllabi: not a case is cited, no code provisions or statutes are cited, and it is not broken down by lectures. It is in effect a précis of legal and equitable remedies, in rem and in personam; obviously a brief guide to the subject. For remedies and for the subjects under the Second Branch Pomeroy relied on the standard texts. There is no indication that there was "discussion"-if there was, it was probably more like the general, free-flowing discussion of the first year than the kind of "discussion" that obtained in the second.

The Pomeroy System and the Langdell/Ames method bear comparison. Beyond both being caseoriented, the similarities are less evident than the differences. The Pomeroy System was just that, a system, an entire curriculum of three years in which something different and unique was done each year in a progressive development that was deductive in the first year (working from the generalities of law to the particular doctrines of law), diametrically opposite, inductive in the second year (working from the particular of cases to generalities of doctrines), and reductionist in the third year (bringing all of the learning acquired to bear on the practical dimension, the "remedial," of legal practice). 
The Langdell/Ames method was just that, a procedure for reducing the law to make it manageable enough to be learned, or perhaps, more accurately, to reduce it to a method for learning each branch of the law, because in their method the LAW ceased to exist as an entire structure, being reduced to so many discrete groupings of doctrines reflecting a practical development that was principally jurisdictional and "remedial." The Pomeroy System presupposed that the LAW was more than the sum of parts labelled property, contracts, torts, equity, etc. The Langdell/Ames method did not concern itself with more than the parts, and could be applied to any part, without respect to its origins, development, or present state, with equal facility. What parts should be taught was, of course, a matter of curriculum planning, though largely dictated by the practical dimension; in what order the parts should be taken didn't make a great deal of difference, though for the first year the Langdell/Ames disciples increasingly favored the "biggest" or "grandest" parts that the method's narrowed perspective of the law could conceive of: Property, Torts, Contracts, Criminal Law.

Behind the Pomeroy System was an understanding that the LAW was a development of history and ethics, and that in our legal system a fully-formed lawyer was produced by the study of cases, codes, legislation, and especially the "municipal law" of the United States and its principal state jurisdictions, against the background of historical and jurisprudential knowledge. Behind Langdell's case method was an almost fanatical positivism, a view that law was a science reducible to principles which could be determined by finding the "right" cases and winnowing out the "wrong" cases. Legislation, he felt, was a nuisance, the intervention of non-legal purpose in the law which would corrupt the "axioms" of the "science" and should be tailored (or butchered, if necessary) to fit the cases. And the cases, the "right" cases, were principally English cases, the fundamental cases of our system, not the cases from American courts. 
Now, what appeared to be inductive-from the cases to the doctrines-in fact was deductive, from the doctrines to the cases. As Grant Gilmore, a perceptive current critic of the Langdell method, puts it, Langdell had no intention of studying all the cases, only those not "useless" for the purpose of "systematic study." Gilmore concludes that "the doctrine-the one true rule of law-does not in any sense emerge from the study [in the Langdell method] of real cases decided in the real world. The doctrine tests the cases, not the other way around." 11 Gilmore may not be charitable, but he is substantially correct in describing Langdell as an "essentially stupid man who, early in his life, hit on one great idea to which, thereafter, he clung with all the tenacity of genius." ${ }^{2}$ No one could so characterize Pomeroy. His System was the product of the evolving experience of a subtle mind of wide-ranging interests and correspondingly broad knowledge. The System was too good for an epoch of legal educational development during which the law itself was narrowing, becoming wholly functionalist and increasingly simplistic.

What kind of "discussion" did the second-year course feature? On the answer turns another parallel (some might argue a departure) between Pomeroy and Langdell/Ames. Indeed, the emphasis on case study was not confined to Pomeroy and Langdell as pioneers; Hammond at Washington, St. Louis, used a case method. Did Pomeroy, though, by some sort of so-called "Socratic method," carry on the disciplined and pointed dialogue that Langdell attempted and Ames perfected, the case-putting argumentation that we today call the "case method?" Elihu Root, recalling Pomeroy at NYU in the 1860s, wrote to Pomeroy's son, in 1906, that his father had had a broad and accurate learning, a powerful and discriminating mind, and a strong sense of proportion,

but he had also an innate and overwhelming impulse, which drove him at legal questions as if they were tribal enemies. ... Into the fields of conflicting decisions, which so confuse the 
younger student and the older practitioner, he would lead us with amazing vigor and enthusiasm, and presently order would appear, compelled by ... high intelligence in the application of fundamental principles to confused conditions. ... His method of working was an especially valuable example of thoroughness in the collection and testing of all necessary data before beginning to reason towards conclusions, and of breadth of view in determining what data were necessary; yet the greatest benefit came from the spirit in which he worked, which made the discussion of the dullest subject seem the most delightful pastime. ${ }^{13}$

Root's description seems to indicate that even at that early date Pomeroy practiced a form of Socratic dialogue; it is hard to see how all this could be read as an hour's continuous brilliant monologue. The reference to "discussion" should be táken literally. Henry McPike, '81, gave some insight into Pomeroy's method at Hastings (albeit writing a half-century later). Noting that Pomeroy lectured in the first year, he recalled that sometimes Pomeroy would:

pause and quiz the class, passing questions around indiscriminately, and treating all answers with gravity, no matter how far off any of them might be. He corrected errors in the most kindly spirit, and in turn when questions to him were ventured, he would give ear patiently and an answer was always vouchsafed. . . . ${ }^{14}$

McPike mentioned that in the senior year (possibly a mistake for the latter part of the second year) Pomeroy used advanced sheets of his Equity Jurisprudence in that course, and taught by "the actual case method," referring constantly to the "leading cases, from which the text rule was deduced, and urged and encouraged the constant reading and study of them." The latter statement does not go one way or another to the use of a Socratic dialogue, but "quizzing" a first-year class where there was no pretense of using the case method argues that Pomeroy would almost certainly employ the same technique in later classes where the case approach was heavily stressed. On the other side, Slack, writing for a Boston journal in 1889, observed that "the lecture sys- 
tem of instruction was at first adopted," but because of objections to it, "formal lectures are not now given except on special subjects." ${ }^{15}$ While textbooks were being used in 1889, "leading cases are constantly referred to and required to be studied" (that had also been required by Pomeroy) and "comments are made, to such an extent as may be thought necessary, but they are chiefly informal." Slack said that discussions and recitations had become daily practice. Slack's testimony must be understood to refer to a difference of degree rather than of kind. That Slack went a step further than Pomeroy in using dialogue can be accepted; it does not mean that he originated it. The same phenomenon was evident at Harvard. While Langdell did originate a case method there (and published his casebook on contracts to provide the material which in Pomeroy's system had to be gotten from the Reports via the Syllabi), he proved less than successful in applying it in the classroom. It fell to Ames to perfect Langdell's method by a fully Socratic method of teacher-student dialogue. One could conclude that Pomeroy's System was heavily case-oriented, but that in the classroom implementation of it he, like Langdell, fell victim to all of the hazards raised by a pioneer's inexperience.

The measure of any curriculum is not only what it contains and how it is conveyed, but how the acquisition of knowledge gained from it is tested. At Hastings, at the end of the third year, there was a comprehensive final examination, both written and oral (in the early years, some of the Directors sat as oral examiners with Pomeroy). The examination covered the work of all three years, with some weighting towards the "remedial" subjects of the third year, as is apparent from the examination papers Mary McHenry kept. With the exception of a paper set for drafting complaints, etc., none of the examinations required much competence in handling the factual dimension of the law, the questions going to doctrine almost exclusively. A question from the constitutional law paper for 1882 will illustrate: 


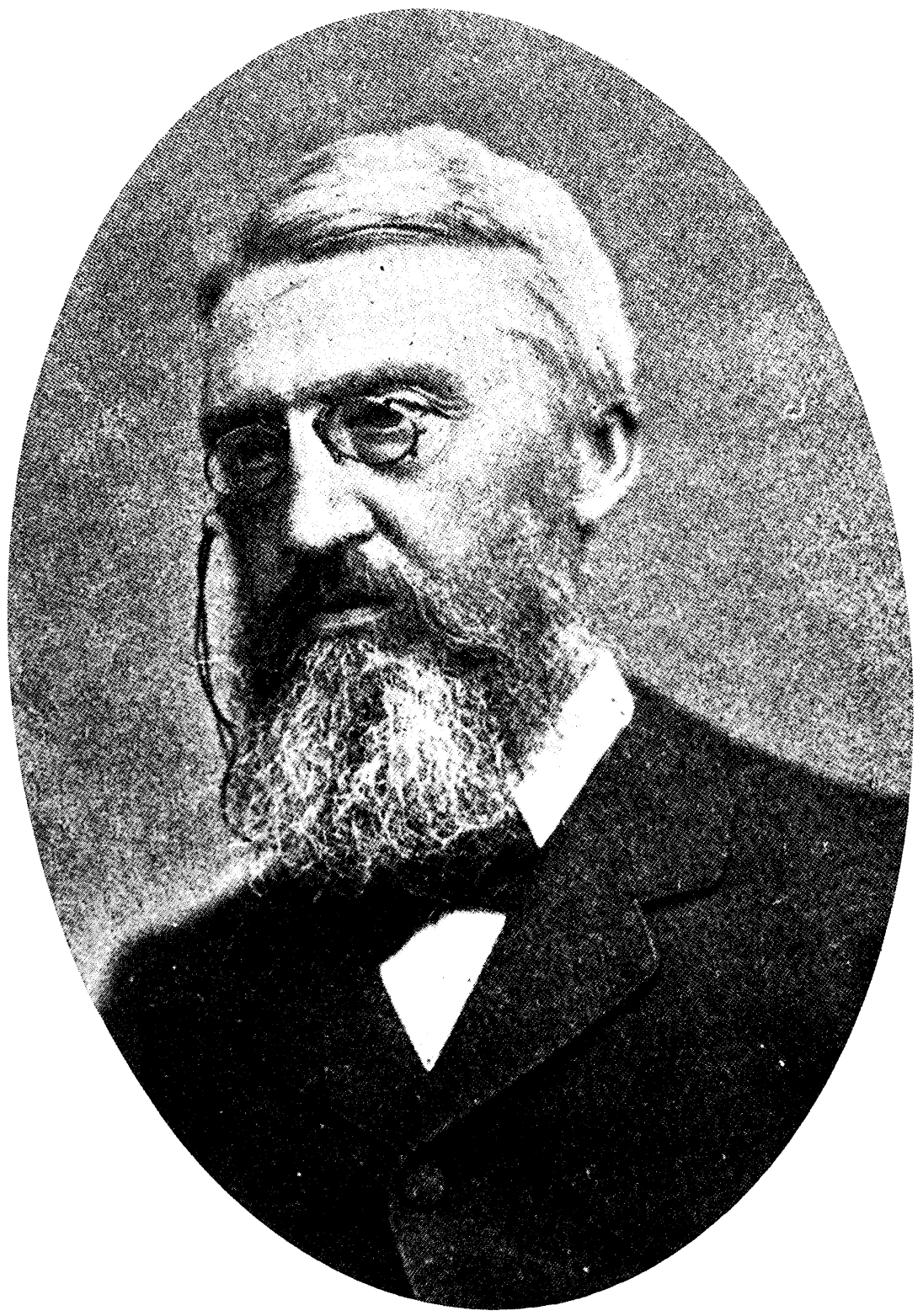

John Norton Pomeroy 


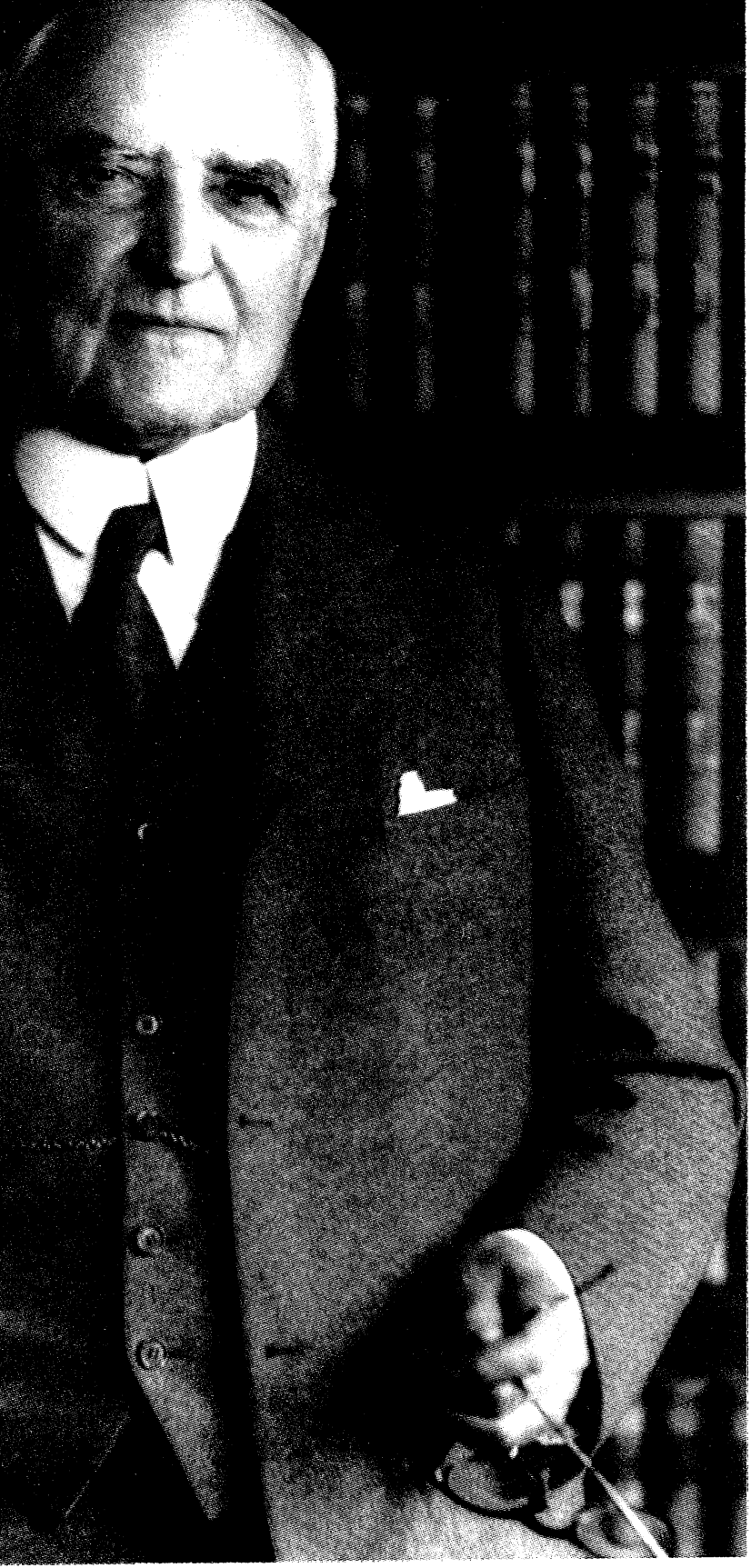

Charles William Slack 
Has the State of California, or any other State, power by statute to prevent Chinese or other foreigners from coming within the State to reside? Give the reasons for your answer. Where does the power of exclusion reside? Assuming that there are no treaties concerning the subject, has or has not the United States Government the power, under the International Law, to prevent the people of any foreign country from coming to and residing within the limits of the United States? ${ }^{16}$

The question was not merely an academic one in 1882 , and it was a good test of the student's detachment as well as of his command of constitutional and international law. Depending on the grade standard (and there are questions as to how high it was in those years), a battery of such examination questions was a good test of knowledge and of the ability to use it.

The Pomeroy System in structure, execution, and examination lived up to its creator's boast that it was truly scientific in classification and arrangement, and practical in its modes of study and the work asked of students. As teacher, Pomeroy inspired universal praise. That he read his lectures, that his voice, while strong and well projected, was monotonic, moved some to wish for a rhetorical flourish or two. But he was in magnificent command of his subject, his material was brilliantly ordered, and for all his dryness (one newsman reporting the Santa Clara Case dubbed him "Pomeroy Sec, Extra Dry" in a play on Pommery Sec, a popular brand of champagne), his intellect inspired the breathless respect that is usually reserved for more charismatic teachers. Rather fragile looking, his pince-nez firm on the bridge of his nose, his outward appearance somewhat severe when he was silent, he broke easily into a stealthy smile. His unfailing courtesy and his felicity of expression had a charm of their own. Elihu Root's image, of Dr. Pomeroy attacking legal questions as if they were tribal enemies, catches the vigor, the infectious enthusiasm, and the power to teach and to move students which is the mark of a great teacher.

John Norton Pomeroy was fifty years old when he 
came to Hastings. The ill-health that had forced his retirement from NYU in 1871 appears to have ameliorated considerably in the climate of California. He loved the outdoors, and explored the Sierras in the summers. Otherwise, he worked twelve hours a day, with enormous mental stamina, giving two one-hour lectures each weekday at the College, spending as much time as he could in his study, with its view of the Golden Gate, turning out the prodigious work of his last years. His family life was idyllic, his vivacious Georgian wife sympathetic and loving, his three boys and a girl successes-two of his sons, Carter Pitkin, LL.B. '81, and John Norton, Jr., LL.B. '91, followed in his footsteps, the former a collaborator and disciple in his father's last years. He was active in cultural societies, founding with others a San Francisco political science society, at which he read a paper on industrial relations, and his house was always open to old students and such eminent visiting busmen as eminent barrister and political scientist Sir James Bryce. But labor took its toll. He succumbed to a virulent pneumonia on February 15, 1885, not quite fifty-eight years old. Elihu Root pronounced the most just epitaph:

Few men with so little desire for display, with so little personal ambition, making so little noise in the world, have accomplished so much. ${ }^{17}$

The Pomeroy System was the creation of a single brilliant mind. To work effectively it required the labor of a single teacher, and to reach its full potential the teacher would have to have the same brilliant mind that fashioned the System. It verged on the idiosyncratic, requiring commitment to its holism and the perfect collation of its parts not likely to be present in any second party. Only the first two Classes, those of 1881 and 1882, received their entire instruction from Pomeroy himself. In 1880-81, Pomeroy had to teach all three classes, junior, middle, and the first senior class; in 1878-79 there was only a junior class; in $1879-80$, junior 
and middle classes. Teaching all three classes necessitated three one-hour lectures each day, five days a week, for thirty-six weeks, dawn to dusk every day. The classes were large, much larger than they had been a decade before at NYU. It was too much for a man of frail health, who was dedicated to scholarship and had in train an enormous work, which was Equity Jurisprudence. For the next two years, 1880-81 and 1881-82, the junior class was taken by Director Oliver Perry Evans as "adjutant" professor at a modest salary. Evans had just been elected to the superior court of San Francisco, but he carried on at Hastings for two years. He was popular with the students, to judge by class testimonials. With Evans' resignation, the Directors hastily established a chair in "common and statute law" to provide assistance to Pomeroy, and appointed Calhoun Benham to it in September 1882. Benham was a "scholarly and accomplished gentleman" who also had been second to former Chief Justice David S. Terry, and helped incite the duel in which Terry killed Senator David C. Broderick in 1859. Benham took the junior class for the next two academic years, but died sometime in early academic 1884-85. Pomeroy, faced with taking on the junior class for the remainder of the year, hit upon a felicitous shift in having the junior class taught by a graduate of 1882-therefore, a person thoroughly familiar with the System: Charles William Slack.

Slack had been brought as an infant from his native Pennsylvania to San Luis Obispo county, where his father farmed. Slack never lost his love of country, and his childhood experience directed him into a practical bent. At the University of California he was a student in the College of Mechanics, taking the Ph.B. in 1879, his senior thesis "A Problem in the Transmission of Power." What urged him into the law is not clear, but he enrolled in the second class (possibly remaining resident at Berkeley and nonmatriculated at Hastings in his first year), graduating LL.B. in ' 82 . He had caught Pomeroy's eye early on, and in his last year Slack worked as a 
"literary assistant" on volume three of Equity Jurisprudence. Slack had two years of practice behind him when he received Pomeroy's summons to fill in for Benham. What seemed temporary was to last considerably longer. When Pomeroy died in February 1885, Slack was left to carry the whole load to the end of the year. In May, Thomas McIntyre Cooley of Michigan refused the chair, and Slack was named acting professor pending the appointment of a suitably eminent successor to Pomeroy. Save for constitutional law and Roman Law for seniors, taught by William Carey Jones from Berkeley as an unpaid professor (1886-88), Slack carried the entire instructional load for three years. And his service did not end then, but continued until 1901 .

Pomeroy's death and Slack's advent coincided with the worst period of the divisions within the College's government. Slack was left to fend for himself, in total command of the College's functioning. He was a match for the task, despite his tender age of twenty-seven. He was one of those rare individuals whose career, as recorded in the written word, never indicates any hesitancy or weakness, but always purposefulness and mastery of every situation. Slack was formidable. He had high standards for himself and he applied the same to others, without respect for excuses; he suffered neither fools nor weaklings. He was a practical and pragmatic man of cool temper and a sharp, analytical mind. He had great will-power and a capacity for delayed gratification which was evidenced by his ability to work steadily to an end, taking adversity and opposition in stride, whether it was raising Hastings' standards for admission and graduation, husbanding and multiplying the trust that John Henry Boalt's widow created to endow the law school at Berkeley that bears Boalt's name, attending to the multifarious details of his clients in the large estates and company practice that he built up after his years at Hastings, or (not least) waiting a Biblical seven years to marry his college sweetheart until he had the financial surety that his Hastings post brought. He was indefatig- 
able, managing in the 1890 s to be a superior court judge in San Francisco, dean and professor at Hastings, and a Regent of the University. Slack was always direct in discourse, and his candor could be wounding. He characterized those who believed law schools were overcrowding the profession as "persons who were never educated in them, knowing nothing about them, and who will not learn anything." 18 His bluntness might explain why, though he commanded respect as a teacher, he was not loved by his students as Pomeroy had been. While Pomeroy seemed severe, Slack had a penetrating eye that made him appear almost fierce.

The first sign that acting professor Slack was a new broom which would sweep very clean came in May 1886. Four students appeared at a Board meeting on behalf of four seniors who had failed the final examinations. After the student-advocates withdrew, "Prof. Slack made a statement in regard to the matter," and the Directors resolved unanimously that hereafter a passing grade was 75 percent. Equally unanimously, the Board upheld Slack's failing the four as having been "exact justice."19 This is the earliest recorded instance of a grade-appeal at Hastings. The circumstances behind it indicated that a tough new standard would be exacted.

Slack was not content with doing "exact justice" on hapless seniors. He saw the problem as a matter of low admissions standards. The original admissions requirements had been: a certificate of good moral character; a ten-dollar matriculation fee; the ability, in the case of juniors, to "satisfy the authorities of the institution that they possess sufficient knowledge and culture to enable them to profit by the course of study"; and a passing grade on an examination in the study of the preceding year or years for admission directly to middle or senior status. ${ }^{20}$ No one had been admitted to senior status directly, though a number, including Slack himself, appear to have been admitted to the middle class directly. Pomeroy seems to have been more exercised by the absence of a certificate of character than by 
a want of proof of capacity. Henry McPike, '81, was admitted on the first matriculation day only because the Founder, being present, vouched for him, to an audible whisper of, "I wonder who will vouch for the Judge?" from Judge Hudson. ${ }^{21}$ During Pomeroy's tenure, students were matriculated by a kind of brief voir dire that was satisfied by exaggerated (sometimes perjured) claims to Classical learning, and the only requirement added under Pomeroy was that a student must be eighteen. But Slack wanted requirements that were both more rigorous and more detailed. At a Board meeting in October 1886, a committee composed of Prof. Slack and Directors Evans (chairman), Bergin, and Harrison, reported a draft of new admissions requirements, which was adopted. The new requirements demanded a command (to the same level as the admissions requirements of the University for the course in Letters) of English, mathematics (arithmetic, algebra, plane geometry), history, geography, and Latin (Caesar, Cicero, Vergil), to be drawn from specific texts in the humanities subjects. Graduates of the University absolutely, and graduates of other institutions of learning at the Board's discretion, would be admitted without examination. Most significantly, the applicants were to sit written examinations in these subjects at the University in Berkeley with other applicants to the University taking the entrance exams. Except for special admissions (advanced class placement, graduates of other institutions), the Hastings Board was out of the business of admissions (for a time). This was the first step taken to get the Board of Directors of the College out of the administration of the College, and as such it is something of a landmark. That the Board was willing indicates considerable confidence in Charles William Slack. These admissions standards, with only a few changes (most of them towards greater rigor), remained in effect until, in 1911 , students admitted were required to have had four years of high school; in 1912, four years of high school and one of college; and in 1913, four years of high 
school and two years (junior standing) of college. The man responsible for the new higher standards of 191113 was Director Charles William Slack.

Three years after the new admissions standards, Slack looked back at the results with considerable and only faintly disguised satisfaction. He noted that the new requirements had cut the student body by about one-half. Of the seventy-seven students enrolled in 1889 , forty-three had college degrees, and the average age of the students was about twenty-two or twentythree. He wrote:

It would be difficult to find in any college a body of young men of equal number who are superior in point of education, ability, earnestness and in all the qualities which go to make up perfect gentlemen. ${ }^{22}$

Slack had cause for satisfaction; his reform had given Hastings very nearly the highest entrance requirements of any law school in the country and higher than most. The new admissions standards began to reduce the rate of senior failures in 1890. McKinstry and Slack forwarded the names of thirteen seniors who had sat the final exams, recommending that all thirteen be awarded the degree, and that two others absent from the exams because of sickness be allowed to receive the degree subject to successful completion of an early makeup exam. The professors reported, "there never has been a class superior to this in general educational attainments and legal scholarship, and ... they have passed the best average examinations ever passed in the Law School." ${ }^{23}$ Failures would occur again, especially in the lower classes, but with a better entrant it was no longer the slaughter of the innocent.

The following graph gives the total college enrollment from the first year of a full three classes (1880-81) to the last year of the Slack regime (1898-99). The early enrollments were very high (the first junior class, 187879, numbered 103); Hastings' foundation had responded to a genuine need. However, once the backlog of aspiring attorneys that peopled the first few classes 


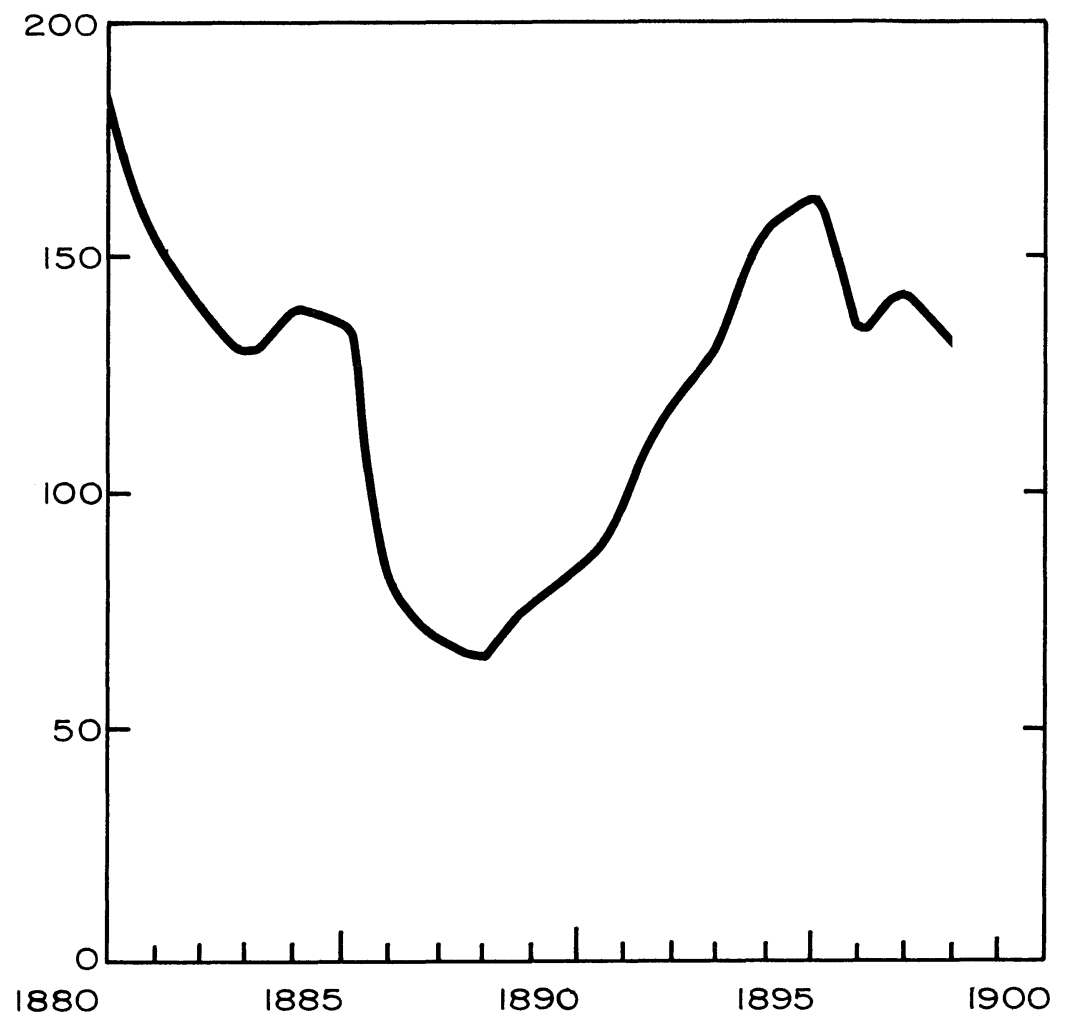

GraPH 1. Enrollments at Hastings, 1880-1898

had passed through, enrollments declined to a steadier flow. Slack's higher standards merely accelerated the decline. The steady increase, beginning in 1889 from the trough of 1887-88 and peaking in 1895 with what turned out to be the highest enrollment until the end of the 1920s, indicates a continuing hunger for legal education in the state, not a falling off of standards resulting in the admission of poorly qualified entrants. The higher admissions standards remained in effect and were even toughened slightly. To some extent the hunger was stimulated by increased enrollments in and graduation from colleges, importantly from the University, but also from other institutions on the Coast, and 
by an increasing tendency to send sons back East to be educated. America was then just beginning its first major takeoff in college education. Hastings, until the last years of the Slack regime, was still the only law school in California, and one of only five west of the Rockies (two in Colorado, two in Oregon). Consequently, it attracted graduates seeking a career in law in somewhat disproportionate numbers. Law-office training was beginning to decline, certainly among the sons of the intellectual elite, the established well-to-do, and lawyers themselves. As Slack put it, perhaps the best proof of the success of the law school "is that judges and lawyers send their sons to it to be educated." 24 The following figures indicate the impact of college education on Hastings enrollments. These are five-year averages of the percentage of LL.B. graduates of Hastings, from the first class of 1881 to the class of 1900, who held an undergraduate degree:

$\begin{array}{ll}1881-1885 & 19 \% \\ 1886-1890 & 31 \% \\ 1891-1895 & 47 \% \\ 1896-1900 & 42 \%\end{array}$

The 1886-90 percentage indicates Slack's reform. In fact, the percentage increase of graduates for the year 1886 alone was 12 percent, and graduate entrants rose to 67 percent with the Class of 1890 (admittedly, of course, the size of the graduating classes diminished, from 25 in 1886 to 15 in 1890). Slack's higher standards merely caught up with a better-prepared entrant, thanks to the increasing college population. The College and the profession were the beneficiaries.

The search for a new professor does not appear to have been prosecuted very vigorously. However, Slack was an ambitious man, desirous of building up a practice, and he was heavily overworked for the $\$ 4000 \mathrm{a}$ year Hastings paid him (which was, incidentally, about $\$ 1000$ more than the average paid a professor at Berkeley). In April 1887, "the founder of this College" was authorized by the Board to engage William Gardiner 
Hammond of Washington University, St. Louis, as principal professor at a salary not to exceed $\$ 5000$. Hammond, who was certainly eminent, turned down the offer. Finally, in 1888, the Board persuaded Elisha W. McKinstry, whose term as a justice of the California Supreme Court was coming to an end, to accept the professorship of municipal law. Slack consented to remain as assistant professor of municipal law at a much reduced salary, and he and McKinstry worked well together until at least 1892, after which the last three years of McKinstry were not so smooth, for reasons that will be made clear. Splitting the work between them, McKinstry took the bulk of the first-year subjects and Slack the bulk of the second-and third-year subjects until 1894-95, when Slack became dean on the resignation of C.F. Dio Hastings (who had succeeded his younger brother, Robert, on the latter's death in 1891). In McKinstry's last year at Hastings, an attempt was made to parcel the work more equitably. Slack was very much the junior partner; he taught more for $\$ 2700$ a year than McKinstry did for $\$ 5000$. Shortly before becoming dean, Slack was promoted to "Professor," but neither this title nor the deanship brought a salary increase or more power. Slack had in fact, if not in theory, run Hastings since Pomeroy's death.

In 1889 Slack reported that "The course of instruction at the college has remained substantially the same as that introduced by Prof. Pomeroy." 25 He was right. While perhaps diminishing lecturing and increasing "recitation" and "discussion," Slack had preserved the Pomeroy System. He continued to use syllabi for the second-year course; the Board authorized the printing of his own syllabi in September 1887. Slack was Pomeroy's disciple. McKinstry, a college graduate (Kenyon College) admitted to the bar in New York in 1847 after reading law in an office, had no strong views on legal education, and was not prepared to be particularly creative in it. McKinstry had a tendency to verbosity (to 
judge from the Reports), but a quick mind and a capacity for seeing to the heart of a legal issue. His opinions were well organized and clear, and he was death on humbug and obfuscation at bar (or on the bench). The Pomeroy System appealed to his orderly and wellhoned mind. The advent of McKinstry necessitated the first significant amendments to the System. Slack and McKinstry had to divide the work between them. In 1889-90, they adopted a system of course rubrics, such as we have today, and although they preserved the names and most of the substance of Pomeroy's subjects, some substantial changes were made. The few headings of torts that Pomeroy taught in the second year were included in the first-year survey under the course, "Persons and Personal Rights." The remaining parts of real property taught in the second year in the System went back to the first year under "Real Property." More significantly, Equity Jurisprudence was made a thirdyear subject and time found for it by simply dropping Roman Law/General Jurisprudence and International Law, since neither professor felt comfortable with these subjects. John Norton Pomeroy must have turned in his grave. On balance, these amendments were just that; save for the casualties of the third year, the structure and the substance of the Pomeroy System were preserved in the rearrangement worked out for the sake of convenience.

The few frills to the Pomeroy System were maintained. Moot court continued, though compulsory participation was restricted to the middle and senior classes in 1886-87, and to the senior class only in 1894-95. Slack and McKinstry dutifully bore with the lectures on legal ethics, the Rev. Dr. William Platt, for all of his reputation, having not been a classroom success. Despite his oratorical skills, his grandiloquence betrayed a shallow and conventional mind, no matter how deep his apparent scholarship might have been. ${ }^{26}$ He resigned in September 1882, and his chair of "ethics of the law and 
rules of morality" was deemed abolished by his resignation. The Founder's insistence, and Pomeroy's own profound belief in the relevance of ethics to the development of law, resulted in the appointment in 1886 of the lawyer-clergyman, J. Harmon C. Bonté, D.D., LL.D., secretary to the Regents of the University, as professor of legal ethics without salary. Bonté was less high-flying and more academically sound and worldly than Platt. He was a success; anyway, the Board enjoined that he should lecture no more than ten times a year. With Bonté's death in 1896, legal ethics as a subject, a feature of the Pomeroy System, died with him.

The next round of changes came in 1894-95, the work of Slack rather than McKinstry. The changes were less substantial than those of $1889-90$, in essence a reordering of the first two years and some cosmetic name-changes that symbolized the abandonment of Pomeroy's Romanist categorization of the first-year course. The Law as to Persons was dropped, and two courses taught by Slack and McKinstry, Domestic Relations and Torts, respectively, were substituted. The new courses, Contracts, Real Property, and Personal Property are clearly evident in Pomeroy's System under his grander headings; the only substantial shift here was more time given to Contracts and less to Real Property. The main change came with a short course on Criminal Law, extending over the whole first year, and taught by Slack. It is not difficult to see why this radical departure took place. Slack had been a superior court judge in San Francisco since August 1891; he was obviously not much impressed with the learning of the criminal law bar. The second-year structure returned to a truer version of the Pomeroy System than it had been with the compacted courses of the 1889-90 amendments. Most of the old subjects were distributed under course titles identifiable with the titles of the System, the only notable addition being Quasi-Contracts (Slack). Probably equal weight was given to each of the nine courses of the second year, a not inconsiderable although subtle 
change from Pomeroy's ornate weighting. The third year remained unchanged from the amendments made in $1889-90$.

McKinstry had recommenced practice in 1890 , sometime afterwards going into partnership with his son. By the summer of 1893 , it was the common bruit that he was not devoting enough time and attention to his teaching. He ignored a letter from the Board for an explanation. In 1893-94, the Board began to assert itself across the entire administration: audited accounts were set up; Edward J. Ryan was forced out as registrar and his place taken by Leonard Stone, '94, who was to be held directly accountable, and that closely, by the Board; and C.F. Dio Hastings (the last of the line to serve in an administrative capacity) found it opportune to resign as dean. On August 2, 1895, McKinstry, who had ignored a final "communication," was fired, and his chair being declared vacant, was immediately conferred on Slack, who became "principal professor" with a $\$ 300$ annual increase in salary. Slack found himself alone again. He could not be a part-time superior court judge, yet the shooting of McKinstry was obviously pour encourager les autres, to "encourage" Slack, and he could not be part-time dean and professor at Hastings. The Board, reluctantly perhaps but of necessity, on August 30, 1885 appointed Warren Olney, Jr., '94 (Harvard A.B. '92) and William Bradford Bosley, Yale, '94, "assistant professors" at a salary of $\$ 1200$ per annum. Both men would long be connected with Hastings, latterly as Directors. With their appointments came the first major expansion in the Hastings faculty: In 1896, Louis $T$. Hengstler, Ph.D., was lured from the department of mathematics in Berkeley to serve as a part-time assistant professor; in 1897-98 Louis deF. Bartlett, '96, served as an instructor for the year, and was succeeded for a year in 1898-99 by Sheffield S. Sanborn.

This expansion in faculty was the death knell of the Pomeroy System. None of the young men had the grasp of the whole that Pomeroy and even Slack had. None of 
them had ever seen John Norton Pomeroy; he was a respected legend only. No matter what his own sentiments were, Slack could not hold his new assistants to the old System. They had already begun to march to a different tune, either to Slack's own variations on the Pomeroy theme, or to their legal training elsewhere, which had taken place to the beat of the ever-mounting crescendo of the Langdell/Ames method. It is significant that the last year in which a Pomeroy book was used as assigned reading at Hastings was 1894-95. Thereafter, the case-books and related texts produced by Langdell's disciples, Ames, Beale, Keener, and Williston predominate. Indeed, it was in these case-books that the Langdell/Ames method stole a march over all others. Pomeroy's System required going from the Syllabi to the Reports; Langdell/Ames served up the cases in a book. Pomeroy never produced a case-book. Sadly, Olney, in third year Equity (no longer Equity Jurisprudence) used William A. Keener's Cases on Equity JuRisdiction (how Pomeroy would have loathed that title) and James Barr Ames' Cases on Trusts. Between 1896 and 1899, the entire curriculum at Hastings was restructured piecemeal, reflecting the reduced perspectives and interests, maybe the diminished capacities, of the bright young men. In 1898-99, Slack's last year as dean and full-time professor, the first-year curriculum was: Elementary Law (Slack, Bosley, Olney, Hengstler); Contracts (Olney); Quasi-Contracts (Olney); Property (Bosley); Torts (Hengstler); Criminal Law (Hengstler); and Bailments, etc. (Hengstler). Elementary Law, a cafeteria course in which four hands were to do the work that once one genius managed, was the last obeisance to the old tradition. Even Slack's earlier Domestic Relations had been shifted from the first year to the second and given the ugly, accurate, and narrowed title, Marriage and Divorce. The second and third years otherwise remained true to the System as earlier modified by Slack. It was the changes in the first year, however, that were the significant ones. The curriculum 
was already manifesting the shift of the beginning of professional courses from the second year, when they had been given under the Pomeroy System, to the first year, as has obtained from that time to this. This was essentially our present-day structure. There is probably no law professor alive who would not remark somewhat ruefully that the Pomeroy System, especially in its introductory first year, provided a panorama of the law that eludes our law schools today.

The Pomeroy System might disappear, but not its emphasis on comprehensiveness. The Hastings curriculum of 1898-99, and for many years after, sought to provide a broad grounding in all practical law. If the horizons were narrower, the program not so well structured to lead naturally from subject to subject with the growth of the student's grasp, Hastings still provided a balanced legal education. To quote an equitable maxim, Arbitramentum aequum tribuit cuique suum, a fair judgment gives each his due, and the Hastings of the twentieth century must render due homage to Pomeroy's System of the nineteenth.

Slack found it increasingly difficult to continue at Hastings to the satisfaction of his students, the Board, and his own high standards. The Board wanted a fulltime dean and principal professor; memories of McKinstry were very fresh. In January 1897, Slack resigned effective the following July. Following a rather formal exchange of letters, Slack agreed to continue at a salary of $\$ 5000$ and indicated he would try to wind up his judicial duties and resign his judgeship. The next year he decided otherwise, resigning from Hastings in May 1898, but agreeing to remain as caretaker dean and professor until a suitable replacement could be found. He continued one more full year as "Dean of the Faculty" before he was replaced as dean and professor. Despite the load upon him, despite some tension between him and the Board, Slack never let his teaching slide. Once he was released from what had become an intolerably heavy burden, Slack and the Board parted 
with mutual respect. His successor and the Board continued to call on his services in the classroom part time until 1901. In 1903 he was named a Director. Only his death in 1945 ended the long association of Charles William Slack with the College that he had come to serve as a teacher for a semester or two and stayed to run for sixteen years. 


\section{$\llbracket \mathbb{V}$ Dr. Taylor's Hastings}

ON MAY 26, 1899, the resignation of Dean Slack was accepted by the Board of Directors. At the same meeting, a very formal resolution was moved that Edward Robeson Taylor, M.D.,

be employed as Professor of the Hastings College of the Law to take charge thereof and conduct the same, subject to the order of the Board of Directors, devoting his whole time and attention thereto and not engaging in any other occupation or pursuit during such employment...1

at a salary of $\$ 4000$, effective July 1, 1899. Five Directors voted aye; two voted no. Thomas I. Bergin (an aye vote) was appointed a committee of one to inform Taylor of his appointment and procure his agreement to the terms. The split vote, even though it was not close, was an inauspicious start to a deanship of two decades which proved to be markedly uncreative and very troubled. On May 29, Taylor wrote a short, correct letter accepting the appointment as professor of the College "to take charge thereof and conduct the same, etc.," and assuring the Board that he appreciated "this mark of your confidence...."2 Taylor was too astute not to suspect undercurrents of doubt on the Board, and his "etc." was a studied bit of equivocation. For the next nine years, he felt no compunction about undertaking time-consuming responsibilities having nothing to do with Hastings College of the Law. In retrospect, 
the College would bask in his reflected glory, but the dean-of-many-parts did not always mind his duties. The vacuum left by his inattention to his office was filled by the Board. The Board's resurgence nearly cost him his job.

Edward Robeson Taylor was sixty-one when he became Dean and Professor of Hastings. He was born in Illinois and schooled in Missouri, and without a trade he migrated to California at the age of twenty-four via Panama and the hellhole of Chagres. He enrolled in Toland Medical College (later the medical school of the University of California) on his arrival in San Francisco, receiving his M.D. in 1865 . He was less interested in practicing medicine than in politics, and two years into his practice he joined Governor Henry H. Haight as his private secretary. Possessed of a quick mind, widely read, an apt pupil, he was called to the bar in 1872, and joined his mentor Haight in his law practice in San Francisco. Taylor was already something of a celebrity in the "instant city," having published four learned papers, between 1869 and 1871 , on what today we call internal medicine; one of these, "On the Chemical Constitution of Bile," was a prize essay of the American Medical Association. A paper on medical training (1872) pointed towards his long career in medical education, which began in 1882, when he became the first vice-president of the newly founded Cooper Medical College (later the medical school of Stanford) and subsequently its president, in the first decade of the twentieth century - all while he was dean and professor at Hastings. He practiced law continuously from 1872, slacking off a bit only after taking the Hastings post. Much involved in the San Francisco pueblo-lands litigation, he wrote a learned paper based on his own firsthand experience in the matter which is still useful. He had a reputation for being an expert on Mexican water-law. He had a good command of languages. Scholars of French literature remember Taylor as the translator of the one-hundred and eighteen sonnets of 
the Cuban-born Hispanic-French contemporary poet José Maria de Hérédia, whose Les Trophées (1893), published in translation by Taylor in 1897, are accounted masterpieces of the sonnet form in French literature. Gem-like, full of nuances, perfectly formed poems, full of Classical lore, Hérédia's poems were magnificently Englished by Taylor. Their appeal to Taylor tells much about the rare qualities of his own brilliance and mastery of language. Unfortunately, Dr. Taylor's own poetry, published in two anthologies just as he became dean at Hastings, verges on the maudlin. ${ }^{3}$

As a politician, Taylor was accounted a reformer, and a pretty radical one at that. He did not seek elective office; when his career in politics reached its zenith, as mayor of San Francisco, the office came to him by election of the supervisors, not at the hustings. Land reform first caught his attention, and his involvement in the pueblo-lands controversy made him well-disposed to radical land reform. In the 1870s he became acquainted with a far less sophisticated but no less brilliant and certainly more creative man than he was himself, who had been a foremast boy on ships, a printer, and latterly a journalist in San Francisco-Henry George. George was an angry man, and his anger was aroused by the land-monopolists, especially the railroad barons, of California. Perhaps the most original of all American economists, one of the really creative economists of the nineteenth century, Henry George postulated the single-tax on land as the device to break economic monopoly. George argued that land values represented the basis of monopoly power, and that by taxing land, rather than its product, industry would be encouraged, economic opportunities would be opened to all, and monopoly would be destroyed. It was Taylor who, in 1878 , suggested to his prickly friend George that what was intended as an article should be expanded into a treatise. Taylor read the manuscript, suggested changes, helped set up the type for printing, and revised the proofs of George's best-selling bombshell of 
1879, Progress and Poverty (still in print in nine languages). George acknowledged that it was Taylor's help, judgment, sympathy, and faith in him that sustained the endeavor. Ironically, Taylor's wife at the time was the niece of none other than one of the greatest railway robber-barons of them all, the land-monopolist who made the Central Pacific Railroad, Leland Stanford.

As political reformer, Taylor took his text from Henry George:

A corrupt democratic government must finally corrupt the people, and when a people become corrupt there is no resurrection. The life is gone, only the carcass remains; and it is left for the plowshares of fate to bury it out of sight. ${ }^{4}$

In the 1880s, Taylor threw himself into San Francisco municipal reform as a sparkplug of the third board of freeholders, the elite citizens' group that pressed for and failed to carry charter reform in 1886 . In 1898, as a member, indeed one of the leaders of the fifth board, Taylor had the satisfaction of seeing charter reform succeed in the new city charter. But he was not long under any illusion that charter reform was enough to prevent the corruption of the people. There was an example of corruption close to home. Taylor knew a young attorney who had entered politics as an idealistic reformer in the ranks of the Republicans: Abraham Ruef, Hastings '86. Ruef had a large practice, was respected as a trial lawyer whose courtroom presentations were "sincere, spirited, and demonstrative" and "always well received." tion outran his idealism and his scruples. He became a ward politician and finally the "boss" of San Francisco politics, leaping onto the bandwagon of the Union Labor Party, managing the election of his handpicked protégé, the orchestra leader and president of the musicians' union, "Handsome Gene" Schmitz, in 1901. Schmitz's reelection in 1903 revealed the existence of corruption; his reelection in 1905 laid bare the extent of a misalliance of corruption and incompetence of ex- 
traordinary proportions. There was nothing left but the carcass of the old reformer in Ruef. Taylor was an early member of the coalition of muckrakers, conservative elite citizens, outraged businessmen, and labor leaders who brought in a private detective and an outside lawyer of questionable reputation but unquestionable ability, and prosecuted Ruef into San Quentin. Taylor was asked by the coalition leaders to take the mayor's office after the prosecution of Schmitz drove him from office, and in July 1907 Taylor was elected mayor by the supervisors. He was faced with having to deal with the disorders of the aftermath of the Great Earthquake of fifteen months before, and with the open grafters capitalizing on the opportunity afforded by the rebuilding of the city. In November 1907, Taylor was reelected by popular vote. He did not choose to run in 1909-had he done so, he might very well have been defeated, for reform was clearly rebuffed at the polls that year, and though Ruef remained at San Quentin, his cronies and counterparts began to come out of the woodwork again. Taylor was fatigued and disillusioned by the firsthand experience of real politics, by his seeming success and profound failure, as mayor. In 1909 he went back to being dean of Hastings, for the first time, full time.

Dr. Taylor came to the deanship suspect because of his zeal for reform, and especially because of his connection with Henry George. He was a bit too much of an activist for the taste of many. He had, however, won the respect of the legal profession by virtue of his success at the bar, and in 1890, 1891, 1894, and 1895 he was elected the fourth president of the San Francisco Bar Association (his predecessors, J.P. Hoge, 1872-79, W.W. Cope, 1880-85, and S.M. Wilson, 1886-89, all having been Directors of Hastings, and Cope still serving). His distinctive intellect and the breadth of his abilities and interests were not likely to endear him to lesser mortals. As his colleague at Hastings, James A. Ballentine, pointed out with entire affection, "Most men with whom he came in contact were his inferiors." 6 Taylor found it 
possible to work with his inferiors only by the exercise of considerable modesty, always forced and perhaps even false. He stooped to conquer. He was affable and a bit playful - a very social man, he was one of the leading lights of the Bohemian Club (the first of an unbroken succession of Hastings deans to be members) when the club was still predominantly literary and intellectual and had the faint aura of restrained naughtiness that its name implied. The club's motto, "Weaving spiders come not here," hardly applied to restless, involved Taylor, who was always spinning webs (albeit honorable ones to catch dirty insects). The club's symbol, the owl, the bird of Athene, the goddess of wisdom, was more applicable. In physical appearance, Taylor was short, somewhat corpulent, with a great wild head of hair (to which he owed his nickname, "Fuzzy"). He had the appearance of a squat, wise old owl. In speech, Taylor affected the oracular when occasion demanded, and his solemnity gave assurance of his wisdom. He could be thoroughly charming. Going with young Ballentine to the latter's house for lunch, he paused in the garden and remarked, "I know I'm going to like your wife. She is so fond of flowers." 7 Witty, he was a good companion in the company of his equals, with Disraeli-like racy self-deprecation. When, in 1908, at age seventy, he made a second marriage, to a young woman of twentyseven, he replied to a friend who had taxed him with not marrying a widow closer to his own age, "I would rather surprise a virgin than disappoint a widow." ${ }^{3} \mathrm{He}$ was not so friendly with those he considered truly beneath him. He was distant and formal with his students at Hastings. When, on his marriage to young Miss Eunice Jeffers, his students gave him an old-fashioned country shivaree (in downtown San Francisco where the couple lived), he sallied forth from the house amid the din of cans and bells wholly unamused and threatened to flunk every student present. He was wont to remark that an effective teacher combined the qualities of scholar and actor. Taylor combined both. But as actor, 
whether in or out of the classroom, Taylor always sought effect. Testy irascibleness and a wounding tongue were closer to Taylor's real personality than his gracious affability when the occasion required it.

As he began his deanship, Taylor had much going for him. Slack had been the first Hastings dean in the style that reached its apex with David Ellington Snodgrass (1940-1963): in command, expansionist, tender of prerogatives, responsible but not subject to the Board, clearly aware of the difference between "running" and "administering" the College, and bent on the former. Slack's relationship with the Board had always been tense; there was the age difference, his former student status, his multifarious activities; but above all, his assertiveness in demanding high admissions standards and in exacting total control over the curriculum was the point of tension. However, he had managed to move the Board out of admissions (although it began to creep back in by "special admissions"), he had kept the Board out of any involvement in curriculum and so managed to justify to it and obtain from it the new appointments that brought the first real expansion in the faculty. The Dean and Professor became perceptibly more and more a dean in the late 1890 s as a faculty gradually formed for him to be dean of. Because until the middle of the first decade of Taylor's deanship the College was not in any financial predicament, Slack was never dependent upon the Board for money-the $\$ 7000$ annuity from the state and the $\$ 10$ per head student registration fees made the modest operation of the $1880 \mathrm{~s}$ and ' 90 s selfsustaining. Slack had living room, and using it he generally enjoyed his own way.

Because the Founder had been the first dean, the deanship was considered essentially honorific in the early years. This honorific quality was reinforced by the breakdown between the Board and the Founder, with a Board-appointed dean, a statutory dean, and finally a dean of reconciliation, J.W. Winans, who didn't serve at 
all, followed by the successive deanships of Hastings' two sons. Slack was the first dean and professor-a relationship between functions that has been maintained from 1894 to the present-so that the Hastings dean of today is involved in the continuous routine of the College at the basic level, instruction. Because of the honorific nature of the early deanship, there was no need to have the dean as a regular attender, ex officio, at Board meetings; with the Founder as dean, it was indeed most desirable never to have him attend if possible. Both of the Hastings sons were Directors as well as deans, and so present at Board meetings. Slack did not attend Board meetings, though on occasion he was invited to appear and report to the Board, which he did. The only nonDirector present was the Registrar, who was secretary to the Board and the Board's formal channel to the dean, who was his superior after all. At least theoretically, this was a poor arrangement, a breeder of ignorance on the Board's part and of distrust on the dean's. In fact, it isolated the Board and insulated the dean. The gulf worked to keep the Board out of the College's functioning and encouraged the dean to exercise the initiative.

The Board that Taylor faced was unchanged from that of the Slack deanship, but only four of the original nine Directors were still serving: T.B. Bishop, O.P. Evans, T.I. Bergin, and W.W. Cope (the latter 1878-85, and from 1893-1903). During Slack's deanship, the most active Directors were three of the grand old men: Evans, Bishop, and Bergin. Of these, Evans, having taught in the 1880s, best appreciated Slack's problems. Bishop and Evans were active on committees, the work of which became increasingly useful and prominent in the Board's functioning. Ad hoc committees were the rule; the only permanent one was the auditing committee, its purpose being to hold the registrar accountable and to keep expenditures down. Bergin was vicepresident of the Board from 1893, and so took the chair in the absence of the Chief Justice, who was ex officio president of the Board. Among the newer Directors, 
Ralph C. Harrison (1885-1917) was a hardworking and balanced man, active on committees. From 1889 until his death in 1914, Chief Justice William H. Beatty was president, remarkably assiduous in his attendance and always a moderating influence. Robert Y. Hayne (1891-1903), one of the original Superior Court judges of San Francisco in 1880 and in active practice after leaving the bench, was a faithful attender and, with Harrison, a good committeeman. Henry S. Foote (1892-1903), a former governor of Mississippi, could be troublesome; Cope stayed in the background; and C.F. Dio Hastings (1890-1907) never attended a Board meeting after his resignation as dean in 1894. By and large, there was no factionalism evident in the Board. From issue to issue the Directors divided in different ways, allied on one issue, splitting on another.

Most striking is how infrequent Board meetings were. From the outset, the Board was to meet monthly; this remained the ideal, but it was never attained. One to three meetings a year was usual; some years there appear to have been none. Occasionally meetings failed for want of a quorum (five Directors). Attendance fell off in the late 1890s and in the first few years of Taylor's deanship. The Directors were aging and over-occupied with other pursuits, and Slack's administration had given them very little to do. Accepting the report of the three-man auditing committee on the quarterly registrar's account constituted the major routine of Board activity. Meddling in admissions began again in earnest in the last years of Slack's deanship. Behind it lay a deep division over how high standards should be-Bergin, Harrison, Hayne, and Foote agreeing with Slack that the higher the better, and Bishop, Evans, and Cope worried about the impact of higher standards on enrollment. What really occupied the Board's time was the ongoing problem of housing the College.

Taylor started with a strike against him in the split vote for his appointment. It was a more parlous situation than the initial 5-2 vote indicated. The two "no" 
votes had been cast by Bishop and Foote, two of the three members of the committee charged with finding a successor to Slack. Evans, the third member so charged, had apparently persuaded the Board to make the selection at large, and he was not present at the meeting that appointed Taylor. Evans' success was nothing short of phenomenal. It was up to Taylor to use the inheritance of the Slack deanship to recover lost personal ground. Instead, he dissipated the inheritance, though not over any great issues. Taylor taught a steady ten hours per week, the single largest teaching load, and by all accounts, he taught well. He was also careful to give the Board an annual report of the College's functioning. What was wanting was any great enthusiasm, the demonstration of real assiduity on his part. He not only continued his association with the Cooper Medical College, but from 1903 on he became increasingly involved in the municipal politics that brought him his finest hour. He continued to practice law. In short, at least superficially, he was neglecting the terms of his employment so explicitly laid down in the resolution of appointment.

If Taylor was doing his job adequately, what he was not doing was exercising the office of dean in the activist manner that Slack had. And there was a growing apprehension that an activist dean at Hastings was a necessity: The law department at Berkeley was beginning to look like a law school. When Louis Hengstler, at his own request, transferred from Berkeley in 1898 to teach full time at Hastings he had been replaced by two young men, and in that same year William Carey Jones' persistence paid off in the creation of the "Department of Jurisprudence" at Berkeley. Students from this department were expected to enter Hastings in the middle class. In 1897, the Hastings Board had rescinded a resolution, passed in the previous year, requiring students to be graduates of the University, other specified California universities, or equivalent institutions of higher learning. This had been a sore blow to Slack, but 
the new higher standard had been wholly unrealistic at the time. The aborting of the new standard, however, gave a spur to the Berkeley department's development, because if Hastings had become entirely postgraduate, the Berkeley department's function would have remained wholly preparatory. As it was, one of the new young Berkeley professors in 1901 could boast that, "With the interest in the new department shown on all sides, the latter is certain to make its influence felt and to aid most materially in raising the scientific standard of the profession throughout the State." 9 These were fighting words!

In 1899, Jones found a captain he could march with: Benjamin Ide Wheeler became president of the University, the first to serve more than a half-dozen years or so. He was the first of the "imperial presidents" of the University, and when he retired in 1919, he had tripled the size of the student body and established the first new campus in the "Southern Branch," in Los Angeles. It was in the middle of Taylor's deanship that Wheeler and Jones founded a "School of Jurisprudence" at Berkeley. Already, in 1899, Wheeler had expressed his conviction that a first-rate legal education was obtainable only in the unity of a law school with a great university. In May 1899, Director Foote had raised the alarm at Hastings over what was going on in Berkeley. The new dean had his work cut out for him. As it was, Taylor did nothing, and it was left to the Board to deal with the growing threat across the Bay.

A still more nagging problem arose with Taylor's expansion of the faculty. Slack had increased the instructional staff to five, and Taylor, in 1903-4, added another instructor. Faculty salaries were not increased (if anything, they were eroded by the replacement of relatively short-term staff with less well-paid successors). But the income was going down. From the time of the first faculty expansion under Slack, the $\$ 7000$ annuity from the state had not been enough alone to pay for the operating expenses of the College, and the ten-dollar 
student registration fee had been depended on to make up the difference. However, from a high in the late 1890 s of an average of 135 students each year, enrollments had plunged to an average of 85 each year in the early 1900 s, and the income from student fees sagged. The Directors faced dipping into their invested fund (about $\$ 35,000$ ) that they had built up over the years by a tight hold on expenditures and astute investment of such surplus money as came in. This they would not do. Neither would the dean cut back on faculty, although an argument could be made for one less assistant professor. At that point the Board, not the dean, came up with the solution. In July 1906, Director Slack moved that the Registrar, Leonard Stone, be let go (after twelve years of very efficient service) to save his $\$ 50$ per month salary. Taylor undertook the Registrar's duties until 1910 without extra compensation. The Board froze faculty salaries, and faculty undertook heavier teaching loads without more pay. James A. Ballentine was most onerously overworked.

On April 18, 1906, the roof literally fell in. The earthquake destroyed City Hall, making Hastings homeless. The College, forced to find other quarters, was also required to pay for them, and the $\$ 50$ per month saved by dismissing the registrar just covered the rental for temporary quarters during the first two years after the earthquake. Not until 1909 did the state again appropriate funds for the College's rent, as it had from 1880 to 1899 , before the City undertook, under the 1878 act, to provide quarters gratis in City Hall. In the midst of this physical and financial crisis, Taylor managed to make do by moving Hastings for two years to his other seat, the Cooper Medical College. He then went off to save the City. The Board might applaud his public spirit, but in 1907 and 1908 it witnessed its dean displaying administrative skills and energetic application on behalf of the City that he had never demonstrated for the College.

As the Board had changed considerably between 
1889 and 1893 , so it went through another round of changes between 1903 and 1907. This was more startling than the first round, because it was more sudden and the new men were markedly a generation younger than those recruited earlier. At one Board meeting, August 28, 1903, three new Directors were appointed by the existing Board. Charles William Slack was appointed in place of Henry S. Foote, who had resigned the previous November, virtually forced out because ill health and his absence from California meant that he could not be relied upon to make up a quorum. William C. Van Fleet, a Republican who had enjoyed a brief tenure on the Supreme Court from 1894 until defeated for reelection in 1898-brought down because his opinion, in a case on appeal in which a laborer's child had been killed by a streetcar in Oakland, appeared to be class-inspired-was made a Director in the place of W.W. Cope, deceased. James M. Allen, another judge of the original Superior Court of San Francisco, was appointed in the place of R.W. Hayne, his colleague on that court, who had recently died. Neither Van Fleet nor Allen had had any intimate relationship with Hastings, but both were men of pronouncedly conservative, even old-fashioned views. In 1906, Walter B. Cope, currently President of the San Francisco Bar Association and son of W.W. Cope, was put in the place of T.B. Bishop, who had died in the previous year. With C.F. Dio Hastings' death in 1907 and his replacement by Hoyt Hastings, who was an active member during his first few years, a majority of the Board was thus constituted of members appointed in the preceding four years. The new members, relatively young, were energetic, committed, and effective. The Board, beginning to chafe at its inactive role, regained from the faculty final approval of graduates, and from 1904, when the books were accountant-audited for the first time in ten years, it established regular outside auditing to reinforce the Board's own auditing committee. The most active Directors, Bergin and two new men, Slack and 
Allen, were prepared to take any steps necessary to keep the College going if the dean was not prepared to do it himself.

From among the five new Directors came three of Dr. Taylor's nemeses. On October 2, 1908, VicePresident Bergin moved the following resolution:

Resolved that the contract now existing between Hastings College of the Law and Edward R. Taylor, the Dean of the College, be terminated, said termination to take effect on December $31,1908 .^{10}$

One Director was absent-O.P. Evans. The ayes were Allen, W.B. Cope, Van Fleet, and Vice-President Bergin. The noes were Chief Justice Beatty, Harrison, Hoyt Hastings, and Slack. The resolution failed to carry only because of even voices. It was a close call for Taylor. Had Evans been present, he would doubtless have voted against the motion. Edward Robeson Taylor was present; as acting registrar he was secretary pro tem of the Board. He had been allowed to defend himself, and he had been able to say, justifiably, that he had not missed classes. But the attack was not upon Taylor as professor; it was directed at him as dean. That Bergin, who was a solid and dedicated Director, had come so far around was a measure of the erosion of confidence in Taylor. Allen and Van Fleet took a high notion of duty, and they found Taylor's radicalism distasteful. W.B. Cope might have had a less noble motive: he had been a classmate of Abe Ruef at Berkeley, was a director and counsel of a realty company which had given Ruef a $\$ 30,000$ bribe to advance a development project, and he had been of counsel with other of the defendants in the graft trials of the Ruef-Schmitz machine. In the event, Taylor got the point. He did not stand for reelection as mayor in 1909. He devoted the rest of his career to Hastings, and only to Hastings. It was a chastened, not quite so arrogant Dr. Taylor who left the Board meeting that day, stooped, not conquering. 
San Francisco burned down, in whole or in part, six times in the 1850s. Conflagration was the greatest hazard of the "instant city." What happened on April 18,1906 , and in the fires that raged for days afterwards, was cataclysmic. When the $\$ 7,000,000$ City Hall disintegrated, leaving only the outer walls and the steel frame and cap of the dome standing, Hastings College of the Law became one of the sorrier victims of the Great Earthquake. Since 1901 the College had occupied three rooms on the third floor, vacated by the move of the district attorney to the Hall of Justice. The Board had grudgingly put $\$ 1200$ into furnishing the rooms, and the City was to provide heat, light, and janitor service. In the middle of winter in 1902 the students complained of no heat in the lecture rooms. The College found it expedient to hire its own janitor from among the students (usually a boy from Southern California for whom the $\$ 20$ monthly salary just paid for his room and board) - the beginning of Hastings' long and honorable tradition of employing students that continues to this day. At the eleventh hour-March 1906-Bergin and Slack were still trying to negotiate the services with the Supervisors. From April 18 to the end of the spring semester, the College had no lecture halls; for the only time in its history, Hastings was shut down. The dean and Registrar also lost most of the College records, which they had kept in City Hall and in their respective offices elsewhere. The worst loss, though, was shattered hope and long expectancy. In 1901, Hastings had finally found a home, not an ideal one, but satisfactory. The move to City Hall had been the exercise of an option, a considered choice between two alternatives which even at the time was the less advantageous one. From the retrospect of the burning buildings of downtown San Francisco, it was calamitous.

From 1878 to 1901 , Hastings' instruction had been carried on in decidedly makeshift quarters. Save for two years (1880-82) when the lectures were held in the se- 
vere and small Academy of Sciences at California and Dupont Streets, the large assembly hall of the Society of California Pioneers at 808 Montgomery Street was Hastings' home. There, beneath the clutter of California curiosities (including a large Arizona meteorite), the maps and portraits redolent of the great events of the already dim recent past, the first class met, and all the other classes heard Pomeroy, McKinstry, or Slack. The Founder had believed such quarters more than ample. For lectures they were adequate until, in Taylor's early years, the amount of time each of the three classes spent in the classroom began to increase. Under Pomeroy and Slack, the student spent one hour per day, five days per week in the classroom. The first-year students met in the morning (beginning at 8 a.m. or 8.30 a.m.), the second-year in mid-afternoon, and the third-year in the late afternoon. Taylor believed that sound educational practice demanded ten hours of classroom time. His expansion of the faculty was intended to provide this doubling of teaching hours. Moreover, the newly recruited, largely part-time faculty composed of active practitioners made it clear that they had to have afternoons free; consequently, all classes were held in the morning, which was also a boon for the large majority of students who worked in law-offices as well as attending Hastings. More than a single lecture hall was needed, however, one lecture hall for each class being a necessity. Slack and Taylor both recognized the real disadvantage in having the dean's office and the Registrar's office separate from the lecture halls, and from each other. From 1895 to the end of his deanship, Slack maintained an office in Pioneer Hall on Montgomery Street, while Registrar Stone remained in the old Emporium Building, a considerable distance away. Slack especially was well disposed to any opportunity that might bring the entire College into one place in San Francisco.

In 1895, Adolph Sutro, then mayor of San Francisco, offered to the Regents of the University thirteen 


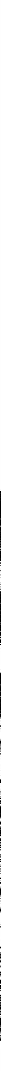

Sutro Heights, "Affiliated Colleges," 1899.

The building on the right was intended for Hastings. 
acres of a twenty-six acre site on the sandy slope of Mount Parnassus, known as Sutro Heights. Sutro was a wizard mining engineer, a real estate speculator in the City, a visionary and self-styled city planner. He was also a bibliophile, and he proposed that one-half of the site house his enormous library. The cranky and near-senile Sutro suggested to the Regents that on the other half be sited the "affiliated colleges" in San Francisco: the (Toland) College of Medicine, the College of Dentistry, the College of Pharmacy, and Hastings College of the Law. A Regents' committee was already working on such a grouping, and Hastings had been invited to send two delegates from its Board to assist the committee in selecting a site. O.P. Evans handled the negotiations, insisting that Hastings was entitled by the 1878 act to have a separate building for its sole use. The Sutro site seemed ideal to the Regents. But Sutro had tied up the offer with near-impossible conditions, and it was some time before the gift was accepted and construction begun. Sutro pointed out that the site was a fifteen-minute ride from City Hall, and that before long a streetcar line would undoubtedly be run to the area. The view of the Golden Gate and the accessibility to Golden Gate Park would relieve the "drudgery of student life" and spur the young scholars to higher achievements. ${ }^{11}$ Though the Hastings Board actively pursued negotiations with the Regents' committee as the construction began, in April 1897 it also opened negotiations with the City to see if space could be had in the new City Hall. By the end of 1899 , the three buildings on the site were finished, the other colleges had already moved in, and the Regents pressed Hastings for a decision as to whether or not the College would move in to the westernmost of the three buildings which had been reserved for its exclusive use. The Board stalled until the San Francisco Supervisors assured them that space would be available in City Hall, at which time it informed the Regents that they would not take up the Sutro space. An anthropology collection was put in the handsome, solid stone, 
Richardson-Romanesque building. The new building was ample enough to have served the College for decades to come, with lecture halls, offices, and library space. But the Hastings Board turned down such munificence principally because of the distance of the location from the law courts and the San Francisco Law Library, preferring to subsist in cramped (and unheated) quarters. On April 18, 1906, City Hall fell in; the massive buildings on the Sutro site survived (the last of them was demolished in 1967 for more medical school facilities).

There was a double price paid for the Board's myopia and Taylor's unwillingness to take the leadership in providing the College with adequate facilities. The number of moves that Hastings made between 1906 and the move to hopelessly inadequate quarters in the new City Hall in 1916 were wearying and harmful to Hastings' competitive stance against the other growing and more adequately housed law schools in the Bay Area. From 1906 to 1908, the College was in the Cooper Medical College, Sacramento and Webster; from 1908 to 1909, in the Grant Building, at Seventh and Market; from 1909 to 1913, in the Whittell Building on Geary; from 1913 to the spring of 1916, in the Underwood Building on Market Street. Each move cost a higher rent, offset from 1909 on by increased state appropriation to cover the rent. If the new City Hall in 1916 looked like the promised land, the College was soon disillusioned. After seven years in that wilderness, the College managed to find somewhat more adequate quarters in the long-bruited, newly constructed State Building in the Civic Center. There it would remain for fifteen years.

The higher price paid was in the perpetuation of the Abe Lincoln Myth of legal training-that a comprehensive modern law library was an unnecessary luxury for law students, who could learn the law from texts, without much reference to the legal sources requisite for legal scholarship. Admittedly, in the first decade of 
the twentieth century and the victory of the Langdell/ Ames method, the Myth was reinforced. After all, Langdellianism managed to reduce all the law to the "right cases," and the mass of the reports could be ignored as long as the "right cases" were in hand. The flood of case-books that the Langdellians produced became the new texts; they were abundant and every student could purchase all that he needed. However, long after other law schools became aware of the fallacy of this notion and emphasized legal research in statutes, reports, treatises, journals, etc., Hastings remained locked into the case-books almost exclusively, in part because it did not have the space necessary to provide real library facilities until 1953. By not having moved to the Sutro site, Hastings remained dependent upon such library facilities as its students could compete for with the bench and bar in the San Francisco Law Library. It was an excellent library; in the 1870 s it already possessed runs of most major legal, political, and economic periodicals. It also had all of the other series, including the reports, that the most fastidious and searching lawyer needed. ${ }^{12}$ But Hastings students were never much welcome in a library where the facilities were always overtaxed. The Founder's parsimoniousness had initially dictated that there be no separate library facilities for the College, though even he, by the end of the first decade, had begun to see the necessity for a College library and for at least a small collection of necessary works. Later, when Slack resigned as dean, he urged the Board to set aside a special fund for "library purposes," but nothing came of his proposal. From 1910, the College did begin fitfully to collect runs of reports and certain journals, always, however, sacrificing acquisitions to more pressing concerns. In the early 1920s, in Maurice Harrison's administration (1919-25), acquisitions increased, and the widow of formerDirector Robert Y. Hayne in 1925 presented some 1000 volumes, which capped a series of generous gifts of books by two attorneys, Charles S. Wheeler, Jr., Frank 
R. Sweasey, and by Lawrence W. Young, '25, and others. But it was Charles William Slack who gave Hastings the real nucleus of its present library; in his will he left a magnificent library of 12,000 volumes, including a complete set of the National Reporter System.

The long-term effects of an inadequate library came to rest only in the interwar period. The short-term effect was serious enough. In 1901, Dean Taylor had carried Hastings into the Association of American Law Schools as a charter member. In 1916 Hastings was dropped from membership in the AALS because its library resources were not up to AALS standards. Taylor's successor, Dean Maurice E. Harrison, managed to get Hastings readmitted in 1920, the AALS accepting that the College's statutory right to use the San Francisco Law Library, located on the same floor as the College, constituted compliance with the library standard. But the College's four years out of the AALS was a portent of much more severe criticism of the College's standards.

The Sutro site negotiations had revived the question of "affiliation." The University Regents' solicitude for Hastings' interests, reflected in the very substantial concession that it would have one of the three buildings to itself (whereas Dentistry and Pharmacy would have to share the other smaller building) indicated that the University still considered Hastings in the fold. It is possible, though there is no evidence for it, that the Regents' open arms contributed to the Board's preference for City Hall. The warmer the Regents' embrace, the cooler the Hastings' Directors became, fearful of being drawn into a closer relationship with the University than then existed under the 1878 act and in the incomplete affiliation that had obtained since the 1880s. Anyway, thirteen years after the last committee-of-one (O.P. Evans) to consider affiliation had been discharged for want of business, the Board on May 9, 1901, appointed a three-man committee, O.P. Evans, T.B. Bishop, and R.Y. Hayne, "to enquire into the Status of the College as 
to its affiliation with the University," and to report at the next meeting. ${ }^{13}$ The absence of President Benjamin Ide Wheeler from Berkeley delayed the discussions, and nothing appears to have been done until, in November 1902, the committee was discharged and a new one appointed. This time, Chief Justice Beatty, T.I. Bergin, and (again) O.P. Evans, were charged to confer with President Wheeler and "agree upon a course of action concerning the relation of the two institutions." 14 Incidentally, this committee appointment marked the emergence of T.I. Bergin as the principal power on the Board. Yet, despite the critical nature of the issue, this was the last to be seen of the committee or of its deliberations in the minutes of the Board. There is no doubt what gave such directness and urgency to its mandate. The Berkeley department of jurisprudence had added four additional lecturers, and would at the May 1903 commencement award Bachelor of Law degrees to three postgraduates who had completed a full threeyear professional program in the department of jurisprudence of the College of Social Sciences. From the bosom of alma mater had appeared the asp of competition. No longer was the Berkeley department merely preparing students to enter Hastings in the middle year. It was now in the business of granting degrees. It did not require prophetic powers to foresee that the granting of three law degrees would soon be followed by many.

The commotions of mid-decade, Taylor's insouciance, and a general sense of helplessness appear to have prevented any appropriate response to the Berkeley challenge. But by 1910, the necessity for defining further Hastings' relationship to the University could no longer be ignored. Elizabeth Boalt's generous gift in memory of her husband, Judge John H. Boalt, had enabled the Regents to begin construction of the small elegant building - the first Boalt Hall-which today is called Durant Hall and is on Campanile Way. It was ready for occupancy in January 1911. The flyer to raise 
money among lawyers for the Boalt Hall building fund was a barb tossed at Hastings, stating that the University's objective was "to create not merely a law department of good standing, but a center of legal education of the highest rank-a Harvard and Columbia of the West. ..."15 More than once, Wheeler had referred to Hastings in terms that would indicate his opinion that it was a "law department of good standing," with the implication that it was nothing more.

In May 1910, the Hastings Board held two important meetings. Both dealt with the challenge of Boalt Hall in two different ways. Charles William Slack, true to form, believed that the way to meet the Berkeley challenge was by making Hastings everything that Boalt could hope to be, and more, and to begin by taking in better prepared and perhaps brighter students. Slack, then both a Hastings Director and a Regent of the University, was also a trustee of the Boalt endowment. Six months before, he had persuaded the Board to appoint a committee under his chairmanship, with T.I. Bergin and R.C. Harrison as members, to review the admissions requirements. The committee was hopelessly split, 2-1, against an ambitious plan of Slack's to raise the admissions standard to that of the Berkeley department of jurisprudence, which the University's Academic Senate had recommended be raised three steps over three years. Slack had the backing of the University's Academic Senate. In a written minority report, Slack pointed out that the College's requirements had not been changed for many years (not since his deanship, in fact, though he was too clever to mention that), "while the requirements for admission to institutions of learning generally have been constantly increased. ..."16 $\mathrm{He}$ was blunt, with a touch of hyperbole: "the entire University has been discredited throughout the country by the low standard of the requirements for admission to the College...." But his proposal that by academic 1913-14 the requirement for admission be raised in three stages to the equivalent of junior standing at 
Berkeley, an aggregate of six years of high school and college, was the right medicine. Beginning with academic 1910-11, his proposal also would put the supervision of admissions at Hastings in the hands of the Berkeley Academic Senate. Put to the vote of the Board on May 31, 1910, Bergin and Harrison voted against it, but Perry Evans, J.M. Allen, W.C. Van Fleet, and Slack-the three Directors appointed on the same day in 1903-voted yes. If Slack's rhetoric was hard to swallow, his reasoning was sound. The higher admissions standards had by 1914 cut back the size of enrollments by about a quarter of what they were in 1909 and 1910 , but to about the same level as they had been in the five years before 1909. Hastings was henceforth in a competitive position with respect to Boalt. When, in 1911, Taylor suggested restricting direct entrance into Hastings' middle and senior classes, Slack and Harrison consulted with eastern universities and then recommended that advanced standing be given for work done at other law schools, provided they were members of the AALS. The Slack reforms of 1910 and 1911 brought Hastings' standards to a par with the best law schools in the country-including the fledgling one across the Bay.

The other response to the Berkeley challenge was a curious one. On the same day that Slack's admissions reform passed the Board, Judge Harrison moved that the Class of 1910 be recommended to the first district court of appeal for admission to practice in all the state courts. Such explicit direction for what had always been a matter of course had point to it. The Board probably intended its ex parte motion for admission of the twenty-three graduating LL.B.s would result in obtaining judicial recognition that Hastings was the law department of the University of California. A judicial opinion of this sort would serve notice on the Berkeley jurisprudentialists that while they might provide legal education, they would not be training lawyers for admission to the bar on the same terms as Hastings under the privilege accorded Hastings graduates by the 1878 
act. On June 1, the day after the Board's resolution for the graduates' admission, Dean Edward R. Taylor appeared as counsel for the twenty-three graduates In Re Students of Hastings College of the Law ${ }^{17}$ before the Court of Appeal, and moved the admission of the twentythree. To Taylor's consternation and the anger of his twenty-three clients, T.I. Bergin also appeared, ostensibly as counsel for the Board. In fact, Bergin represented no one but himself; it was Taylor who was doing the Board's bidding. Bergin spoke against the motion to admit, on the grounds that Hastings was not part of the University and was not affiliated with the University beyond the pious hope expressed in the 1878 act. Bergin's motives might have been of the best, and derived from a sincere wish to avoid a declaration from the bench that affiliation had, as a matter of law, taken place. He might also have been moved by his considerable animus towards Taylor, dating at least from Bergin's unsuccessful attempt to oust the dean two years before. The court rendered judgment, finding that it was its duty to grant the license since each of the graduates had a diploma signed by the President of the University. But it went on to hold:

We must presume that official duty has been regularly performed, and that the faculty of the university has granted the diplomas in pursuance of the law. We must also presume that the said Hastings College of the Law has affiliated with the university of the state; in fact, the Legislature, by its many appropriations for suitable buildings for the law department of said college, has time and time again recognized the Hastings College of the Law as a department of the university. The very title of the act is "To create Hastings College of the Law in the University of California." The questions as to whether or not the said college has, as matter of law, affiliated with the university, and as to whether or not the faculty of the university has granted the diplomas which the said persons hold, cannot be tried collaterally on this application. ${ }^{18}$

The court's judgment both went too far and did not go far enough. It did not establish "as matter of law" 
that affiliation had taken place and that Hastings was the law department of the university. It merely presumed this to be the case. At the same time, it was a presumption that might prove grounds for a dangerous precedent in the future. Bergin's sally had succeeded to the extent that the court was not prepared to provide a definitive determination of the College's status vis-à-vis the University. From the Directors' point of view-and in this, Bergin was as one with Harrison and Slack-it was better that the court's judgment be limited to the admission of that one class of graduates on the basis of the most narrow interpretation of the privilege accorded by the 1878 act. On June 24, the Board "respectfully requested" the court to delete that part of the judgment quoted above. The court refused to amend its opinion. Clearly, the Board's attempt to establish that Hastings was the law department of the university had gone down to resounding defeat in a judgment that carried considerable potential for future mischief. Even if the Court of Appeal had bought the obvious try-on in Taylor's motion, it is questionable whether the judgment would have made much difference. Boalt Hall could not have been so easily strangled so long after birth. The despair of the Directors is understandable. Clark Kerr's "multiversity" was a half-century away, Robert Gordon Sproul's multi-campus empire forty years in the future, and Benjamin Ide Wheeler's "southern branch" still a decade from realization. No one could have conceived of the University as having two law schools, let alone the four (if we include Hastings) which it has today.

At this same 1910 Board meeting, the committee formed in 1902 to confer with Wheeler was discharged. In the next two years, Hastings worked out an understanding with the President of the University for formal certification of graduates by Board action and biennial reports of the College for presentation to the Regents, including the names of Hastings faculty. (From 1913 
on, these reports were annual.) In 1914, the University's Extension Division requested and was granted use of the Hastings lecture halls when the College was not using them for extension courses (not in law). In 1913, the Board went back to worrying affiliation again, appointing Van Fleet, Warren Olney, Jr., and Slack a committee to investigate the legal status of the relationship and report on what they "deemed advisable to bring about a formal affiliation" of the institutions. ${ }^{19}$ In August 1916, the Board discussed affiliation again, and joined a new Director, William B. Bosley, with Olney and Slack on the committee-all three of whom had been faculty members at Hastings before becoming Directors. These committees were exercises in futility. Without affiliation, and without defining what the relationship was, Hastings and the University were once again living together in relative amity and in slightly less isolation from one another than before. But it was still no marriage.

If Taylor became far more involved in Hastings' affairs after his close call of 1908, he did not prove to be any more creative a pedagogue than he had been before. In turning to the much expanded faculty of his deanship and the courses they taught, one is struck by the solidly competent but unexciting teachers and the adequate but unimaginative curriculum for which they were responsible. There were still little touches of the Pomeroy System left, most notably in Taylor's own first-year course in Real Property, in which he lectured (the subject that best lends itself to the lecture treatment, especially in a code jurisdiction). In his third-year Equity course, while he used that most Langdellian casebook of Austin Wakeman Scott of Harvard, Taylor still had "reference to Pomeroy's Equitable Jurisprudence."20 Indeed, Taylor agreed with Pomeroy completely in deploring the perpetuation of the dual system of law and equity, especially in the code system, in which equitable principles were too often submerged. 
Edward Robeson Taylor, however, was the last man left on the faculty who found merit in what Pomeroy had done. The new men were very new. It was with mixed pride and regret that Dean Taylor, in 1901, could recommend the appointment as assistant professor of Robert W. Harrison, LL.B. Harvard 1898, describing him as a man of scholastic attainment who "knows thoroughly the Harvard method of law teaching, which in the main we ourselves follow." ${ }^{21}$ Harrison was the first thoroughgoing and Harvard (Ames)trained exponent of the Langdell/Ames method, and he had considerable influence with his colleagues. He was the son of Director Harrison. Taylor noted his disposition for industry and research, and mentioned his fine mind, the latter a point concurred in by some and disputed by others of his students. He was extremely personable and well-liked, even loved, by his students. He had plenty of time to leave his mark on Hastings, serving longer than any other member of the faculty, from 1901 to 1947. Throughout his career, his courses ranged over the entire spectrum of civil law, though his main interest was property. He was far too occupied with extra-Hastings pursuits to be a great academic, but his students remembered him with fondness and respect. Suitably, a chair was endowed in his honor after his retirement.

Of Slack's recruits, only Louis Hengstler remained by 1901-02 (if Sheffield Sanborn, LL.B. Harvard 1897, who had been an instructor in 1898-99 and served again as an assistant professor, 1901-03, is excluded). Hengstler was a brilliant man, who had been trained as both a mathematician and a lawyer in his native Germany. He had begun at Hastings in 1896, while retaining his Berkeley assistant professorship in mathematics and jurisprudence; by 1898 he had come to Hastings exclusively, though technically part time, and was promoted in 1901 from assistant professor to professor. Over his years at Hastings, he built up a large San Francisco practice that moved him to give up teaching in 1916. He was cold and 
severe in class, brooked no noise, and was called "the Prussian General" by his students. When a future justice of the Court of Appeal and his pal were playfully kicking each other during class in the demonstration theatre at Cooper, Hengstler, who alone could see the commotion, stopped the class until they stopped scuffling. He taught a variety of courses, but his mainstays were third-year Evidence and Constitutional Law. The intricacies of both appealed to him, though he sometimes found it hard to get his students to see through the intricacies as clearly as he did. He was an early and faithful convert to the case method, which he employed with such verve and inquisitorial zeal in the classroom that he made it truly socratic. With his resignation, Taylor's faculty lost its brightest intellect.

Besides young Harrison, Taylor's recruits included men with a wide range of abilities, but all were men of competence. Orrin Kip McMurray, LL.B. '93, taught pleading and practice for two years while also teaching at Boalt, where he had a distinguished future, as professor and from 1923 to 1935 as dean. William Denman, a UC graduate and LL.B. Harvard 1897, was on the faculty for three years contemporaneously with McMurray, teaching first-year Contracts and a third-year course in Admiralty which did not survive his resignation. There was considerable turnover in junior faculty during the years 1903-10, doubtless some of it attributable to Dean Taylor's inattentiveness to the College. Besides McMurray and Denman, four other assistant professors taught for short periods, one of them, Walter S. Brann, '96, being remembered as an exceptionally fine teacher of Contracts, practical in his approach and stimulating. The turnover was highest in Contracts until Golden W. Bell was hired in 1911. A 1910 Harvard LL.B., Bell remained at Hastings until 1930, despite a large admiralty practice, government service, and the associate editorship of American Maritime Cases. When he went to Washington in 1930, his course in Contracts fell to another young Harvard 
LL.B. who had a future at Hastings, David E. Snodgrass. The turnover left the burden of continuity to Hengstler, R.W. Harrison, and James A. Ballentine; the latter, who had no law degree, was hired in 1904. Though Harrison and Ballentine could be counted on to fill in on short notice where needed, Ballentine was treated badly; his salary remained the lowest for the amount of work done of any faculty member throughout most of Taylor's administration. That the College had to purchase the law dictionary which was his sole scholarly achievement (and is still in print) was just retribution. ${ }^{22}$ To Taylor's credit, in 1916 he did move the Board to increase Ballentine's salary from $\$ 600$ to $\$ 780$ a year.

The faculty began to firm up in 1910 with the appointment of Robert W. Harrison's brother, Richard C. Harrison, whose field was pleading and practice; with Golden Bell's appointment in 1911 and that of his brother, George L. Bell, in 1912, the faculty received its finished form that would obtain to the end of Taylor's deanship. Two young men were added in 1916, Thomas A. Thacher, LL.B. Yale, '10, and Alan C. Van Fleet, Director Van Fleet's son. Thacher and George Bell went off to civilian war service on leave, and did not return. By the end of Taylor's deanship, a remarkable continuity in the faculty had set in. This stability was welcome, and it testified to a more stable administration achieved after Taylor settled down.

The faculty was a good faculty, but it was not an outstanding faculty. It was not distinguished by scholarship, though Ballentine had a name known through publication, and Taylor's articles had won him a reputation, already fading, however, in the second decade of the century. The faculty's claim to quality lay in its classroom competence, which in turn was based upon the teachers' professional practice. All of them, even the younger men, were practitioners, and the more senior of them very well practiced. All were recruited from the San Francisco bar, but Hastings LL.B.s did not predom- 
inate, and the Harvard and Yale men were prominent. In 1916, in looking for two instructors to replace Hengstler, the Board's search committee wrote the deans of leading Eastern schools for leads to their recent graduates practicing in the Bay Area; both Thacher and Van Fleet, the men hired for constitutional law and evidence, respectively, were products of Eastern schools. All had LL.B. degrees save Taylor and Ballentine. Only Taylor was full time, with ten hours per week; all the rest were part time. The Board felt compelled to give sporadic but sometimes intense attention to assuring that the faculty did their appointed teaching. It was necessary. Robert W. Harrison and Hengstler (until he reduced his load to four hours per week) came closest to Taylor in amount of teaching time, six hours per week. During Taylor's deanship, Harrison taught his six hours, and concurrently taught either at the Y.M.C.A. Law School (Golden Gate) or San Francisco Law School, practiced law until 1912, and from 1906 was successively chief deputy district attorney of San Francisco, deputy attorney general of California, and chief deputy and first assistant attorney general, until he retired in 1942. Harrison was a very busy man, absolutely assiduous in his teaching, but hardly in a position to bring to it that creative flair that makes a good teacher a great teacher. There was little else that the Board could do about teaching other than make its sporadic checks on time spent in the classroom. The quality of teaching was not something that they were much interested in, save in 1905 when the Board left it up to individual Directors to visit classes if they wished. A strong dean-one more energetic and committed than Dr. Taylor-would have been able to get more out of a faculty. It was a constant refrain during those years that as soon as a class was over, the professor bolted. There was no time for casual contact. The students had to pay a price for the excellence of the practical dimension of their instruction.

It was certainly not high salaries that kept good 
teachers at Hastings; there was no general increase in salaries between 1899 and 1921. Taylor was paid $\$ 4000$ throughout his tenure, and on promotion from assistant to full professor, Hengstler and Robert W. Harrison got very modest increases. Of the rest, only Ballentine had a small upward adjustment in 1916 because he had been so grossly underpaid for so long. The wide variance in the faculty's hours resulted in some marked discrepancies in pay rates. The following table shows the faculty, their instructional load in hours per week, and their annual salaries, monthly salaries, and the rate for each expressed as one hour per week per month, in June 1916.

$\begin{array}{lcrrr}\text { Professor } & \text { hr.lwk. } & \text { per yr. } & \text { per mo. } & \begin{array}{c}w k .-h r . \\ \text { per mo. }\end{array} \\ \text { E.R. Taylor } & 10 & \$ 4000 & \$ 333.33 & \$ 33.33 \\ \text { R.W. Harrison } & 6 & 1500 & 125.00 & 20.83 \\ \text { L.T. Hengstler } & 4 & 1110 & 92.50 & 23.13 \\ \text { Asst. Professor } & & & & \\ \text { R.C. Harrison } & 5 & 1000 & 83.33 & 16.67 \\ \text { J.A. Ballentine } & 4 & 600 & 50.00 & 12.50 \\ \text { G.W. Bell } & 3 & 600 & 50.00 & 16.67 \\ \text { G.L. Bell } & 2 & 390 & 32.50 & 16.25\end{array}$

(This was before the adjustment to Ballentine's salary, and clearly shows his inferior salary position relative to other assistant professors, though he was the longest tenured of the four.) Adjusted to full-time basis (ten hours per week) and compared to average salaries at the University of California in 1916, Taylor was paid virtually the same salary as a Berkeley full professor. Considering R.W. Harrison and Hengstler more as associate professors than full professors, their average annual salary, if full time, would have been about $\$ 2650$, which was $\$ 200$ more than associate professors were paid at Berkeley. The assistant professors were just $\$ 50$ per year lower than their equivalents at Berkeley. Hastings' salaries were not out of step with the University's, but whereas University salaries had risen by about 15 percent between 1899 and 1919, Hastings salaries had 
remained frozen, and the initial salary advantage of the Hastings professoriate was lost by 1919. A solidly frozen salary over two decades is not much of an inducement to academic improvement.

If a certain stability came ultimately to obtain in the faculty, the curriculum showed signs of becoming static. Slack's earlier reforms had been modifications of a system, Pomeroy's System. Within a few years of Taylor's administration, the Slack curriculum was transformed. The shift of the basic subjects in legal education from Pomeroy and Slack's second year to the modern first year was almost accomplished by 1901-02, with four major, basic first-year courses: Contracts, Real Property, Torts, and Criminal Law. During McMurray's two years (1903-05), a fifth course was added, Common Law Pleading; it disappeared with McMurray, but with R.C. Harrison's appointment, Pleading came back to stay in 1912-13. The Big Five first-year courses had arrived. The second-year courses varied considerably in number, but tended to be refinements of subjects that had been taught under a broader rubric during Slack's administration: where there had been Corporations, now there were Private Corporations and Municipal Corporations, the latter giving over to Public Service Corporations by 1915-16; Agency spun off Carriers. Trusts essayed an existence separate from Real Property as a second-year course for ten years, and then became a third-year course. The third year remained truer to Slack's modified Pomeroy System, the heart of it being Equity, Pleading and Practice (until in 1915-16 that was put over entirely to the first year), Evidence, and Constitutional Law. The curriculum had some perceptible omissions. In 1918, eighteen students petitioned the Board for a course in Admiralty in the third year. The Board referred this remarkable instrument (the first indication of formal student input into curriculum at Hastings) to the dean and faculty. Nothing came of it, though in Golden Bell the College had an eminent practioner in admiralty. 
It would be unjust to tax Taylor and his faculty with not having attempted something radically different from what all other law schools in the country were doing. By and large, with few exceptions, and most of these post World War I, American law schools during the first four decades of this century were saddled with the rigidity of a single system that was rapidly losing its capacity to inspire and stir innovation in the men teaching the law. The period was a dismal age in American jurisprudence as a whole. ${ }^{23}$ It required the Depression as the malady and the New Deal as the therapy to open up the law and the law schools to new concerns and new subjects. Hastings under Dr. Taylor was not alone in its increasing ossification in the curriculum. What gives unusual poignancy to the process at Hastings is the contrast between the exciting old system and the dull new structure. A man of Dr. Taylor's catholicity of interests and multifarious abilities ought to have done better. He at least might have tried.

Edward Robeson Taylor's last decade at Hastings was untroubled. There were no complaints; there could not be because the place kept functioning. The First World War was a hard period. Enrollments sank from 99 in $1917-18$ to 34 in 1919-20. We find it difficult to comprehend how big an army this country fielded in the $\mathrm{AEF}$ in a very short time and how war activism and patriotism gripped young men with an almost hysterical embrace. Colleges and universities were literally stripped-and a number of small law schools went under. There was talk of closing Hastings. To his credit, Dr. Taylor held firm and confident. He was failing fast, in his eighty-first year when the war ended. Athene's bird looked more sleepy than wise. And the saddest part of his growing old was that it took the edge off his passion for the good life, companionship and gourmandism, witty conversation, and the bibulous arts. $\mathrm{He}$ knew when to quit, and he knew how. On February 13, 1919 , he wrote his letter of resignation to the Board of 
Hastings College of the Law, to take effect on July 1 next, at the same time informing the Directors that he was presenting to the College a portrait of himself painted by his Bohemian crony, Pitzella. No false modesty in Dr. Edward Robeson Taylor. Slack moved a short but gracious resolution of thanks, naming Taylor emeritus professor of law. Taylor also knew how to retire. He did not haunt the halls of Hastings, but stayed in his comfortable house with his young and adoring wife, reading the French and English classics which one suspects were really his greatest intellectual delights. Hérédia, whom Taylor so much admired and whose sonnets he had translated, said of poetry that it "dwells in nature and in humanity, which are eternal, and not in the heart of the creature of a day, however great." Taylor would have agreed with the poet's high notion of the creative act, and he might have taken some comfort in that thought if he reflected at all on what more he might have managed to create at Hastings. He died on July 5, 1923 . 


\section{Aurea Aetas}

$G_{\text {REEK AND Roman poets praised }}$ Aurea Aetas, the Golden Age, when men lived in arcadian simplicity and idyllic prosperity, happy, undefiled by sophistication, crime, and greed. This blissful vision has never faded. Western man since has not ceased to hope, even when he could not believe, that such an age existed. With a compound of nostalgia and optimism, the children of Classical civilization still drape the time-past in the raiment of golden virtue. Fifty years of reign, or marriage, or even mere existence suffice for a golden jubilee, from the vantage point of which all that went before appears transformed-ill to good, pain to pleasure, misery to joy, poverty to prosperity, and enmity to friendship. In 1928, Hastings College of the Law celebrated its golden jubilee, and its sons and daughters looked back at the fifty years past with unalloyed satisfaction and genuine pleasure. If they looked forward at all, it was without anxiety for the future. Were those first fifty years Aurea Aetas? They had not been simple; prosperity and happiness had not always prevailed, and hurt and disorder had sometimes stalked the College. Greater difficulties were already upon Hastings by 1928 , and worse was to come. There was no reflection of this, only of the sentiment of pride, in the historical essays contributed to the Golden Jubilee Book, 1878$1928,{ }^{1}$ and prepared for the occasion by Orrin Kip McMurray, '93, Chief Justice William H. Waste, '94, 
Chief Justice Frank M. Angellotti, '82, Henry C. McPike, '81, Charles W. Slack, '82, Professors R.W. Harrison and J.A. Ballentine, and ex-Dean Maurice E. Harrison. Yet the contribution of the dean, William M. Simmons, "Ideals and the Future," was sobering. It struck a somewhat apologetic note with respect to the other leading law schools in California, emphasizing too vigorously Hastings' uniqueness as a law school in close proximity to the courts, and its reliance on local students to fill its classrooms. There was a note of isolation-and isolationism-in Simmons' essay. Not least, he was forthright in identifying the growing problem of the inadequacy of the College's physical facilities.

Certainly Hastings would not know again the advantage of preeminence by age. In the next fifty years it would play a different role in California legal education than it had in the half-century of its primacy. It is now time to look at the last years of the Golden Age, the 1920 s, to see a Hastings that had given California formal legal education, some of its greatest judges and lawyers, and a high standard of excellence-a Hastings on the eve of hard challenges. "As wee reade of them which in oulde tyme lyued in the golden age," we can catch something of the pride and the satisfaction that the first half-century engendered.

Hastings' oldest dean was succeeded upon his resignation in 1919 by its youngest dean. Maurice Edward Harrison was not yet thirty-one when the Board appointed him dean and professor of law on June 13, 1919 , at the same annual salary of $\$ 4000$ as Taylor's had been. Slack had chaired the search committee, which had taken three months and some pains to find a new dean, without success. As late as May, still facing the prospect of having no dean for the coming year, the committee was preparing to recommend temporary instructors to take Taylor's courses. It is probable that there were some doubts that the right man had been 
found. Not only was Harrison appointed to hold the appointment "during the pleasure of the Board," but it was well known that he had a sizable practice of nine years' standing in partnership with his father. No pressure was put upon him to devote his whole attention to Hastings; he continued in practice throughout his tenure. Harrison was never entirely satisfied with his post. In 1922 he submitted his resignation, only to be persuaded to stay by an over-generous deal: a salary of $\$ 6500$ for only six hours, rather than ten hours, of teaching per week. The Board set out to search for a successor to take over in 1923, but without success. In March 1924, Harrison again signalled his intention to resign if his teaching load was not further reduced. Though his partnership with his father had ended, he was still in practice, and he was on the verge of joining that soon-to-be prestigious firm of Brobeck, Phleger, and Harrison. The Board reduced his load to four hours per week and reduced his salary to $\$ 5900$ for 1924-25, but in January 1925, Harrison submitted his final resignation, effective June 30, 1925. He joined Brobeck and Phleger and enjoyed both a practice at the bar and eminent public service that brought him to the top of the profession. From 1935 until his death in 1951 he was a Director of Hastings, serving also as a Regent of the University from 1944.

Harrison was a native San Franciscan and a product of the University of California, graduating A.B. in 1908. $\mathrm{He}$ was one of the early graduates in the professional program of the Berkeley Department of Jurisprudence, receiving the degree Juris Doctor in 1910. His thesis, "Constitutionality of the Federal Corporation Tax of 1909," demonstrates some potential for scholarship, having the virtues of clarity and conciseness, if not quite the scent of brilliance, that indicate a lively intellect and the ability to order material, facts, and doctrine, and draw reasonable conclusions from them. Harrison had a genuine academic bent. While beginning and advancing 
his practice, from 1911 until his appointment at Hastings, he was a part-time lecturer in law at Boalt. At Hastings he taught Property and Equity, and taught them well, even if his reputation was not that of a brilliant classroom performer. He was a slim, handsome man with very fine features, blest with boyish good looks, a firm voice, and a pleasing manner, and he dressed well almost to the point of dandiness. He made a favorable impression on his students, and his openness and directness in discourse were universally admired. He was also a scholar. Though he was too busy in practice and too soon out of academic life to produce much written work, his article in the California Law Review (1922), "The First Half-Century of the California Civil Code," history of the implementation of the code by the California courts, weighing its merits and demerits and the advantages and disadvantages of Pomeroy's judicially-accepted rule for its interpretation. The article is still reprinted in anthologies, and alas it has not been improved upon as an essay in legal history.

Harrison took great pride in the Hastings of his day, and in its development of nearly a half-century, almost as if he had himself been an alumnus. Indeed, he was responsible for creating the first permanent alumni association and an alumni following for the College. He noted with satisfaction that the students "during the post-war period included, for instance, Bahrs, Bergerot, Eickhoff, Leicester, Treadwell, and others of the second generation of San Francisco lawyers." 3 Such was his genuine esteem for the College-its standards, faculty, Board, students, and uniqueness-that his enthusiasm was infectious. Hastings' reputation had never stood higher than it did during his tenure. That reputation was on the threshold of a rude shaking, but the blow did not come until the early years of Harrison's successor. It was, however, a reputation deserved, founded upon proven accomplishment represented by the College's product of its first four decades. 
The fortieth class of Hastings, and the first to be graduated by Dean Harrison, the Class of 1920, brought to 988 the total number of students who had received the degree LL.B. from the College. This represented an average graduating class of about 25 students per year between 1881 and 1920, though the last five classes had been small, averaging only 11 degree recipients, the World War having dealt a blow upon the blow already delivered by increasing competition. Hastings' students were considerably less homogeneous than those of most other law schools of the period. Where Clara Shortridge Foltz and Laura De Force Gordon had not feared to tread, 20 other women had stayed the course from Mary McHenry's graduation in 1882 to Helen Garland Siebert-Smith's graduation with the Class of 1919. Two students of Latin-American background had received degrees: of these, only Thomas Francis Lopez of San Luis Obispo (who settled in Fresno), LL.B. 1912, was clearly Mexican-American, the other, Roberto Antonio Jimenez, LL.B. 1920, being of Panamanian parentage. Though he had not graduated from Hastings, Pedro E. Zabala, a native of Monterey, studied there for one year, 1887-88, after taking his B.S. at Santa Clara in 1886. He practiced in Salinas and from 1891 to 1899 was District Attorney of Monterey County, enjoying a very good practice and high reputation. A number of Japanese consular officials and students from Japanese universities had been admitted to Hastings from the $1880 \mathrm{~s}$, though the first JapaneseAmerican to receive the degree was Tom Okawara of San Francisco, LL.B. 1919. No Chinese-American had graduated from Hastings. After the United States' acquisition of the Philippines, a number of Filipino students had attended Hastings for a year or two, but none had taken the degree. Though there were a few prominent Black attorneys in practice in the state by the second decade of the twentieth century, they do not appear to have been Hastings graduates. The first Black student (known to me) to enroll in Hastings was Tabytha 
Anderson of San Francisco. She withdrew after her first year, 1928-29. The reasons for her withdrawal are not clear, but apparently she suffered more than the ordinary roughness accorded a freshman in James A. Ballentine's Torts-Ballentine's noted Southerngentleman manners at best fell short of women students and were certainly not color-blind. One minority long discriminated against in professional education was prominently represented from the earliest graduating classes. There had been a steady increase in the number of Jews receiving the LL.B., and by 1920 some of Hastings' most distinguished alumni were Jews, many of them active in B'nai B'rith and other Jewish social and cultural organizations. The College was well in advance of San Francisco society in banishing the pale antiSemitism that kept an attorney of such distinction as Sidney Myer Ehrman, '98, from membership in the best San Francisco clubs which welcomed his Gentile classmates. There is nothing to indicate that there was any discrimination against minorities in the matter of admissions or instruction. Hastings had the most open admissions policy of any law school in the country, accepting any student who met the none-too-rigorous academic requirements for admission. The underrepresentation of minorities grew from the more subtle form of discrimination inherent in society as a whole, from economic inability and lack of educational opportunity. The increasing numbers of graduates from the "old" minorities-Jews and those of Italian, Irish, and eastern European extraction-reflected the increased economic power and educational opportunity enjoyed by these minorities. Indeed, because the fees at Hastings were lower than those of any other law school (including Boalt) and its curriculum and studies program were organized to permit a student to work at least half time, its record in these early years in the encouragement of minority students, to judge by the roll of its graduates, was better than that of its competitors. It certainly of- 
fered better opportunities than were available to minorities in law-office preparation, where old patterns of prejudice and continuing rampant discrimination effectively closed the door to minorities seeking entry to the profession by that route.

Institutions of higher learning bask in the reflected glory of their eminent alumni. Such pride is perhaps even more marked in the case of law schools. The structure of the legal profession, as bench and bar, provides a simple pecking-order of eminence (with the bench at the top), if not of success. There never has breathed a law school dean who did not regularly note, with considerable satisfaction, the appointment of an alum to the bench, the number of partners in major firms who were old grads, the election to important public office of a graduate, etc. In lean times such notice brings some comfort as the dean reaches for his tin cup; at all times, it is a measure of pedagogic success. In an ethos where merit is supposed to bring praise and demerit opprobrium, colleges are happily immune to blame for their sons' and daughters' sins. No one at Hastings had to blush with shame at the revealed corruption of that scoundrel Abe Ruef, '86. And how many today condemn the famous law schools that produced the infamous lawyers-in and around the Oval Office-of Watergate?

While we still have publications devoted to puffing eminence in the guise of "directories" of notables, the heyday of panegyrical instant apotheosis was the late nineteenth and early twentieth centuries. Oscar $\mathrm{T}$. Shuck's History of the Bench and Bar of California (Los Angeles, 1901) was more informative, largely because it was more anecdotal, than the efforts of his successors, but it is too respectfully breathless, high blown, and eulogistic to be entirely convincing. Still, a crude measure of Hastings' impact on the profession in the state within a bare two decades is afforded by the high proportion of former Hastings students singled out for 
homage in the section on "Junior Rank." Of the 165 young lawyers Shuck noted, 38 had been Hastings students, 29 of them Hastings graduates. This represented 23 percent of all those mentioned in this "Junior Rank" category, and 57 percent of those (67) who had attended a law school. Shuck's omission of Charles William Slack, '82, Frank M. Angellotti, '82, and a number of others who by 1901 were eminent practitioners and judges, is inexplicable, but those included were entirely deserving of recognition. Peter A. Bergerot and William I. Brobeck, both '92, Emanuel S. Heller, '89, Edgar D. Peixotto, '88, and James A. Devoto, x'90-93, already were attaining the height of their powers that would number them among the greatest lawyers of the California bar.

A decade later, J.C. Bates, in a compilation echoing Shuck's title, was both more comprehensive (though Slack and Angellotti were still overlooked) and less adulatory than Shuck. ${ }^{4}$ Bates provided factual and low-key notices of 1384 attorneys prominent in 1912, most of them middle-aged. Nearly half of these had not attended law school even for a year, having prepared in an office or privately (one intrepid counsellor proudly noted that he had learned the law in the San Francisco Law Library). A considerably smaller proportion of lawyers without degrees were admitted to the bar after 1900; some law school training was becoming de rigueur. Exactly 11 percent of the total had attended a law school for at least a year; 3.2 percent had attended Hastings, 7.8 percent some other law school. Of the 1,384 attorneys listed, 581, or 42 percent, had a law degree. Of these, more than one-quarter had received the Hastings LL.B. By 1910, the latest year for which there was the slightest possibility of a graduate finding himself in Bates, Hastings had graduated 815 students. The 158 LL.B.s noted in Bates constituted about 20 percent of the College's graduates - a remarkable figure, even if not very meaningful considering how many eminent graduates of Hastings were not included. Hastings 
LL.B.s clearly led the field, and that by a wide margin, in Bates' hagiography. The only law schools that even approached Hastings were the University of Southern California and the University of Michigan, which together almost equalled the 27.4 percent of Hastings LL.B.s found in Bates. These figures mount in significance as they are viewed later in Chapter VI against the challenge mounted by Hastings' competitors. It must be noted now, though, that to all of Bates' shortcomings must be added the further one of bias, represented by his definite San Francisco Bay Area slant. His book was published in San Francisco, and Bates had not entirely perceived the expanding bar of the rising metropolis to the South. Still, so far as Hastings' children are to be found in Bates, res ipsa loquitur.

The indefatigable William Carey Jones, who had played his part in pressing forward legal education at the University of California both by encouraging President LeConte to look with favor on Serranus Clinton Hastings' original proposal and by going ahead with the Department of Jurisprudence at Berkeley, took stock of the whole university in an Illustrated History of the University of California (San Francisco, 1895). It provides the kind of hard biographical data for all Hastings LL.B.s to 1894 which is otherwise unavailable. We can add to it the Class of 1895, and see what the first fifteen Hastings classes had done with their education by 1895 . There were 399 graduates, 18 of whom were dead. The occupations of the living in 1895 can be broken down in percents as follows:

Judges (serving and former)

Attorneys in practice

Court officers, government officials,

reporters, librarians

Physicians, clergymen, educators

In business, agriculture, journalism, real estate, mixed

Of unknown occupation

The serving judges included three members of the Class of 1882. Frank M. Angellotti, elected to the Superior 
Court of Marin County in 1890, was the first Hastings graduate to take a seat upon the bench. Charles William Slack was elected to the San Francisco Superior court in 1891, and in the same year Charles Edward Davidson became a county judge for Crockett County, Texas. Walter Burton Cope, '86, was on the superior court of Santa Barbara County, Abraham Lincoln Frick, '88, a superior judge of Alameda County, and Joseph Emmet Barry, '91, a justice of the peace in San Francisco. Former judges as of 1895 were John Francis Davis, '84 (superior, Amador), and two graduates of 1886 were former superior court judges: John R. Aitken (San Diego) and William G. Britton (San Francisco). H.J. Stafford, '82, and John Joseph Dunne, '83, had been San Francisco justices of the peace, as had a deceased member of the first class, James I. Boland, '81. The former judges had returned to active practice at the bar.

Graduates in practice included a state senator, Eugene F. Bert, '87 (San Francisco) and two assemblymen, Charles A. Swisler, '83 (El Dorado) and H.H. North, '93 (San Francisco). Others also had sampled political power. Four graduates were former assemblymen, all in the early 1890s: F.G. Finlayson, '85 (Los Angeles), and Bertrand Schlessinger, '85, William Hendrickson, Jr., '88, and A.T. Barnett, '89, all from San Francisco. The practicing attorneys included two former deputy attorneys general for California, La Fayette C. Marshall, '81, and C.H. Jackson, '84, and a former attorney general of the Kingdom of Hawaii, Charles Creighton, ' $83-\mathrm{a}$ harbinger of the future prominence of Hastings graduates at the Hawaii bar. The witty Henry Clay McPike, '81, had been an assistant U.S. attorney for the Northern District of California, and that eminent practitioner and jurist, Charles A. Shurtleff, '82, had also served in that office. By 1895, 16 Hastings graduates had served as district attorneys, and six were currently in that office in California counties, pretty well covering the state geographically. A handful of other 
attorneys either had been or still were police court prosecutors or city attorneys. The practicing attorneys were active in local politics as supervisors, school board members, on public works boards, and the like. Two of them played a distinguished role in public affairs: George Lezinsky, '83, had served as a special attorney in 1889 in the matter of railroad taxes before the legislature and was a member of the Executive Committee of the Citizens' Defense Association of San Francisco, and his classmate, William T. Phipps, was currently the manager of the State Anti-Debris Association. Though Lezinsky, in the matter of railroad taxes, was on the opposite side of the fence from his late master, John Norton Pomeroy, Phipps would have gladdened the heart of the old man. Of the five ladies who had graduated from Hastings between 1881 and 1895, only two were in practice. Josephine Melvina Todman, '83, was listed as "attorney and clerk in the office of James H. Budd" of Stockton, and Alice Ann Clark, '95, was struggling to begin a San Francisco practice.

Hastings LL.B.s who were court officers included former or present clerks of the federal district courts and state superior courts; those in government service spanned the continent at various levels and included $\mathrm{M}$. F. O'Donoghue, '82, who was chief of the contest division, General Land Office, in Washington D.C.; Lidell Baker, '85, secretary of the Oregon Railway Commission; and Charles James Evans, '92, U.S. Customs examiner in San Francisco. Other graduates in more literary pursuits: Edwin Du Bose Smith, '91, was associate editor of the American State Reports published by BancroftWhitney in San Francisco; Carter P. Pomeroy, '81, displaying his father's bent, was editor of the West Coast Reporter, editor of the California Codes, and editor of later editions of well-known and much-used texts. James Henry Deering, Jr., '81, was the first professional librarian of the San Francisco Law Library. He built up its large holdings only to see the collection perish in 
April 1906, and went back to work rebuilding the widely appreciated collection to a 70,000 volume excellence by the time of his retirement in 1928. Deering was remembered with genuine fondness by generations of Hastings students, for whom the library was their principal resource, as a scholarly man of simplicity, gentleness, and courteousness. He was always ready to assist them and to shield them against the annoyance of practitioners who considered the students interlopers. He created and edited the great compilation of California Codes known as Deering's Annotated California Codes, produced a digest of the first 136 volumes of California Supreme Court Reports, and in 1886 published a work on negligence that was at the time a significant contribution to the subject.

Some graduates made only slight use of their legal education, preferring other professional paths. The exceptions were three physicians. José de Sousa Bettencourt, '85 (San Francisco), an Iberian who was an M.D. before entering Hastings, Samuel Tevis, '82 (San Francisco), and William Wenzlick, '85 (Port Townsend, Washington) were able to capitalize on the contemporary vogue for forensic medicine, much emphasized by Edward Robeson Taylor. The clergymen-graduates were two Episcopalian rectors, both of that eminent Class of 1882, the Revs. Henry McCrea, of Philadelphia, and Frank D. Miller of Bakersfield, and the Rev. Henry D. Whittle, '83, a Roman Catholic priest and professor at Santa Clara College. Whittle was the most eminent academic among the graduates, and the only one in higher education, if one excludes Slack, the former registrar, E.J. Ryan, '87, and the serving registrar, Leonard Stone, '94, who were actually practitioners.

The twelve graduates who became businessmen were in a number of lines: banking, customs brokerage, petroleum, lead-smelting, salt, railroads, municipal transit, publishing. The four graduates in agriculture were in what for the 1890s was "agri-business" and included a stockman, John T. Wheeler, '88, a former 
Nevada assemblyman and currently sheriff of Eureka County, Nevada. Leander Shores, '81, with becoming candor, listed himself as a real estate speculator and broker in San Francisco. Journalism was the light of James Thomas O'Keefe, '92, editor of the Redwood City Times-Gazette and of Richard Gibson, '87, of San Francisco, and Mabel Clare Craft, '95, was a reporter on the San Francisco Chronicle. Arthur Inkersley, '90, beggars description. Oxford graduate and former Classics master in Australia and New Zealand, the elegant Mr. Inkersley turned his hand to practice in San Francisco (without notable success), continued to tutor in Classics and law in this country, and free-lanced for magazines. $\mathrm{He}$ and a friend, A. Daw-Kerrell, founded the AngloCalifornian Publishing Co. and produced private-press books, including a very pretty calendar of their own contriving (both prose and art), "The Daies of the Yeare 1898, an Auntiente Kalendar," à la Poor Richard's Almanack, with some playful but poor doggerel. ${ }^{5}$ Two gentlemen of Gallic background, a Quebecois named Joseph Louis Dumontier, '90, and Oscar Adolphe Rouleau, '91, worked at the hard, necessary, and not very remunerative task of record-searching in San Francisco.

For the score of graduates to 1895 about whom William Carey Jones was silent, we can add little. A few appear to have become eminent practicers; most disappeared from view. About one of them, simply listed as resident in Berkeley, Mary McHenry Keith, '82, we do indeed know a great deal, and her career was as fruitful as those of the many graduates who practiced the law. Doubtless some did very little with their training. It is sad that Emily Buckhout, '83, one of the three earliest women graduates, who in her youth had espoused the cause of women's suffrage, suffered from ill-health and despondency, though her marriage to Joseph Baker and her move to Oregon provided some solace, if it did not present much opportunity for public-spirited activity. Even if we assume that the score of LL.B.s of 
"unknown occupation" as of 1895 did not make much use of their legal training, a 6 percent black-sheep or lost-lamb factor would have been judged very respectable by Victorian work-ethic standards.

Hastings graduates of the first thirty classes, to 1911, the eve of the first period of heavy competition from other law schools and the dislocation brought by the First World War, not only furnished a great many members of the bench but also a large proportion of the giants of the profession who dominated California law until the mid-twentieth century. Not all of these were practitioners only. Frank Prentiss Deering, '81, brother and classmate of the San Francisco Law Librarian, published the first annotated edition of the Codes of California, in four volumes, in 1886, and was one of the editors of the first thirty volumes of American Decisions. An active practitioner, he lived into his mid-eighties, a warm supporter of the arts, sciences, and local history, a committed Republican and a devout and active Episcopalian layman. Deering had the further distinction of marrying, in 1902, a Hastings graduate of similar literary interests, the journalist, Mabel Clare Craft, '95. Randolph V. Whiting, '95, was not so eminent as Deering, but in a long career, beginning two years after leaving Hastings and lasting for a half-century, he was the sparkplug of the California Reports and California Appellate Reports, bearing the full redactal responsibility for them from 1917. Through the activities of Carter P. Pomeroy, Edwin Du Bose Smith, the Deering brothers, and Whiting, Hastings law graduates came close to cornering the legal-literature market in California for almost a half-century. Orrin Kip McMurray, '93, was another particularly distinguished alumnus, professor of law at Boalt from 1907 to 1940, and dean there from 1923 to 1935, succeeding its founder, William Carey Jones, and spurring Boalt onward in its first great growth period. McMurray, as chairman of the Berkeley Academic Senate, 1921-23, was prominent in the famous "faculty revolt" that curbed presidential-autocracy 
in the University and gave to the academic senate great powers over budget and appointments, complete control over curriculum, and a major voice in administration-prerequisites for the future excellence and eminence of the University of California. McMurray enjoyed an international reputation as a jurisperitus, respected for his range of interests and his vigorous prose style, his commitment to the proposition that the life of the law is life itself, and his capacity to draw on history and literature for illumination of the law. He was probably the most distinguished academic lawyer that Hastings has produced. It was fitting that Orrin Kip McMurray became the first member of the famous "Sixty-Five Club," that eminent body of erstwhile retired law teachers which has borne the brunt of instruction at Hastings for the last three decades.

The College produced some remarkable characters, known for other attributes than merely success at the bar. Matthew I. Sullivan, who attended Hastings for two years, 1878-80, but did not graduate, enjoyed notable success at the bar. He also presided over the Panama-Pacific International Exposition of 1915, the West Coast's first world fair. He was a special U.S. prosecutor for a time in land-fraud cases in the West, and proved an effective harrier of corruption, both in preparing the cases and prosecuting them in court. Close on the heels of these labors, he was appointed Chief Justice of the California Supreme Court, to serve until the next election; in November 1914 he was elected by a write-in vote to continue until the end of the term, after which he refused to run. He was a firm proponent of city planning in San Francisco and authored the original city planning ordinance, serving as president of the city planning commission for thirteen years. He also found time to serve as dean of the University of San Francisco Law School until 1934, seeing that struggling institution through some of its hardest days. Big, energetic, restless, Matt Sullivan left a large and enduring mark on the City and the State. 
In the prosecution that sent Boss Abe Ruef, '86, to San Quentin, Matt Sullivan was one of the special prosecutors serving under the special deputy district attorney, Francis Joseph Heney, forced upon District Attorney William $\mathrm{H}$. Langdon by the reform coalition to clean out the Ruef-Schmitz gang. ${ }^{6}$ Heney was a restless, hot-tempered, and absolutely fearless man. He was extremely belligerent. He grew up "south of Market," bruised and battered by kids bigger in physique though not in spirit. He toiled at night and without family help to get admitted to the University of California - and was expelled his freshman year for fighting, having challenged another student to a duel, squaring off with him in fisticuffs during which a gun was drawn but not fired. Heney, admitted to the bar in 1883, attended Hastings in 1883-1884. Shortly afterwards he drifted into the Arizona Territory, traded in cattle, and ran an Indian trading-post at Fort Apache. He acquired a reputation as an Apache-fighter. In 1889 he hung out his shingle in Tucson, developing a big practice in land-litigation which confirmed him in his hatred of the Southern Pacific Railroad. In 1891 his career and his life almost came to an abrupt end in a scuffle on the courthouse steps with a Dr. J.C. Handy, who was bigger and tougher than Heney. Heney was representing Mrs. Handy in her husband's divorce and custody suit against her. Handy grabbed at Heney's gun-this time the gun went off and Handy was killed. Heney was exonerated. Active in Democratic politics, in 1893 he was appointed attorney general of the territory by President Cleveland. He lasted one year. He charged the territorial governor with corruption, and when Cleveland delayed in sacking the governor, Heney quit. He returned to San Francisco and went into private practice. His zeal against corruption found an outlet from 1903 to 1905, when he served as a special United States prosecutor in public-land fraud cases in California and Oregon. Teamed with the eminent detective William J. Burns, Heney secured the conviction of a U.S. Senator 
from Oregon who had been the state political boss for years. The Heney-Burns team was no less successful in smashing the Ruef machine. In the process, Heney got another taste of his own violence. On November 13, 1908 , in the courtroom during a recess in the RuefSchmitz trial, a deranged man who some months before had been called as a venireman and subjected to a brutal voir dire by Heney which exposed the man's earlier (and since pardoned) crimes, shot Heney in the head. Heney survived, but the prosecution had to be continued by Hiram Johnson (whose success in it brought enormous political reward), assisted by Matt Sullivan and other attorneys. Heney had been much assisted in the prosecution by his clerk, John H. Riordan, '09, who is one of the last survivors from those halcyon days intimately involved in that episode in the history of San Francisco. Heney was too zealous for even the reform coalition, and when he indicated that he meant to probe behind the corrupted to reach the corrupters, coalition support for him waned rapidly. For three years he served the cause with every ounce of his little frame and big zeal. He had received no compensation, and worse, he had made too many enemies in San Francisco. He moved to Los Angeles, where he practiced law and essayed a political career. He shifted parties, from Democrat to Republican to Progressive to Democrat again in a half-dozen years. He fell out too readily with allies-defeated for the U.S. Senate on the Progressive ticket in 1914, in 1916 he came out for Wilson's pacifist-sounding campaign. ${ }^{7}$ His bid for the governorship in 1918 as the Democratic nominee was dashed by his being prevented from getting his name on the ballot. There was still plenty of fight in the old muckraker: In the mid-'20s he was special counsel to a senate committee investigating Internal Revenue. His private practice suffered from his public forays and his reputation as a scrapper. He ended as a superior court judge in Los Angeles, a tranquil conclusion to an almost theatrical career that began in the Wild West before 
Frederick Jackson Turner's “frontier" disappeared, and finished in the fastest growing urban agglomeration of the twentieth century. On October 31, 1937 he died in bed, his "rusty mail" - or rusty sixshooter-hanging on a nail "quite out of fashion," but not "in monumental mockery."

A less colorful figure, but one no less dedicated to good causes, was William Edward Colby, '98, who wielded pen and ice-ax with equal facility. His practice was in mining law, but his heart was in the Sierras. An active alpinist, he was variously secretary, counsel, and president of the Sierra Club, and brought practice and passion together as counsel for the Save the Redwoods League. He was an unyielding conservationist and John Muir's intimate ally in the struggles to create the national parks system. Muir acknowledged that Colby was the only Sierra Club member "who stood by me in downright effective fighting" to have Yosemite taken back into Federal control so as to stop the railroad interests' exploitation of it for tourist trade; that battle they won in 1906, when Colby was only eight years out of law school. ${ }^{8}$ Colby was chairman of the California State Park Commission at a fortuitous time, 1927 to 1936, when unemployment and public-works projects combined to enable California to create the nucleus of its great state parks network. Bright and vital, for more than a quarter of a century Colby lectured on mining law at Boalt. He was a prolific author of law review articles and of contributions to treatises, and he was associate editor of the standard work on mining law, Lindley on Mines, written by the man with whom he began practice. The law of mines and land-use was the subject, but the message was conservation. His marriage was another Hastings romance, and one from the classroom: He married his classmate, Rachel Vrooman, who later was active in Hastings alumni affairs.

Another Hastings "favorite son" was of the same generation. His contributions to bar, bench, and the College have been major and continuous in the six dec- 
ades since he enrolled at Hastings. Absalom Frank Bray, Jr., '10, was in the class that was admitted ex parte in the Court of Appeal in the case, In Re Students of Hastings College of the Law, 1910. Much of his practice at the bar was in public advocacy, as an assistant district attorney and as city attorney for three Contra Costa county cities. Actively, humanely interested in charitable organizations, he has long given unfailingly of his time to service organizations. After serving on the superior court of Contra Costa county, in 1946 he became a justice of the district court of appeal, First Appellate District, retiring in 1964 at the age of seventy-five. "Retiring" has no meaning in his case; to this day he serves pro tem on the court, deftly, learnedly, and judiciously handling a volume of work that fatigues judges half his age. Since 1951, he has been a Director of Hastings (vice Maurice E. Harrison) and since 1959 vice-president of the Board and chairman in the absence of the chief justice. Frank Bray, one of now less than a dozen graduates who link the Hastings of today with the Hastings of the first generation of its sons and daughters, is honored and beloved by his alma mater, still in her service, in the service of the profession, and in the service of the people. As Voltaire observed, "Honor is the diamond that virtue wears on its finger."

The early Hastings graduates produced some notable philanthropists. Alexander F. Morrison, '81, provided the fortune that enabled his widow to give the University of California at Berkeley one of its most notable large gifts, in their joint names. Sidney M. Ehrman, '98, remembered Hastings: He donated its first professorial chair and remained an active contributor of money and service to the College throughout his long tenure as a Director and until his death in 1975. Russell K. Pitzer, '03, provided the basic endowment for the college that bears his and his wife's name-Pitzer College, one of the Claremont group. Pitzer was a Pomona boy, a graduate of Pomona College, which was also the alma mater of his wife, Flora Anna Sanborn 
Pitzer (A.B. Pomona '01; A.B. University of California, '02), a woman devoted to the education and advancement of women. Russell Pitzer still lives in Pomona, a few miles from his benefaction, the newest and one of the most splendid of the Claremont Colleges.

With the dawn of the new century, the California bar began to undergo a fundamental change: the large modern law firm began to emerge. The development began in San Francisco, peaked in the inter-war period, and still determines the structure of legal practice in the state, with Los Angeles having become its leading exponent. In the first generation of its emergence, the large firm was a long way from being symbolized by the crowded letterhead of defunct eminenti, a score of living partners, and another of "associates," privates each hopeful of having a marshall's baton in his brief case. But in 1900, the big firms were on their way. For the first half-century of the common law in California, two-man partnerships of relatively short duration, largely unspecialized, had been the norm. The modern "associates" " various chores were undertaken by "clerks" who might well not be admitted to practice, although they were usually preparing in the office for the bar. The high incidence of shingle-changing looked like musical chairs as partnerships were formed and dissolved. The emergence of the "firm" (even if it was not quite yet a "big firm") owed a great deal to a wide range of phenomena, internal and external to the law. The most significant factor was the growth of large, national corporations, beginning with the railroads in the last half of the nineteenth century, but extending by the beginning of the twentieth to oil, mining, metals, utilities, and finance. The three railroad defendants (Southern Pacific, Central Pacific, and Northern) in the Railroad Tax Cases in Federal District Court in 1883the notable cases in which Pomeroy distinguished himself-were represented by six counsel, including the professor, who were not in partnership with each other and epitomized the single-practitioner or small-partner- 
ship attorney of great eminence and reputation in advocacy. ${ }^{9}$ A quarter of a century later, such a defense would have been centered in a single large firm. Big corporations demanded the talents of big law firms that would look out for the whole range of the corporate client's interests. And the range was broadening: besides the traditional branches of the law connected with proprietal and commercial concerns, the growth of government involvement in both tax and regulatory functions, and the rapid expansion of injury matters with which a corporation had to deal brought new complexities. Specialization, among and within firms, was inexorable. At the same time, and because of the pressures of complexity and non-litigation business, lawyering shifted increasingly from advocacy to counselling. The role of the corporation-client firm increasingly became a matter of intimate involvement in business policy rather than one of forensic activity. Whole areas (not least the criminal law) in which the partnership lawyer of the early days was expected to have some competence and to be at least occasionally involved in disappeared from the lawyer's function in the large firm. As Hurst put it, citing the career of Paul D. Cravath (LL.B. Columbia, '86, of Cravath, Henderson, and De Gersdorff, New York), the new breed of great lawyer "disciplined a large law office, to produce a professional product of high technical quality, through businesslike organization." ${ }^{10}$ The firm became a cohesive team rather than a stable of brilliant individualists. Expansion in the number of attorneys in the firm grew with coordination, contraction in function, specialization, increased business, and every new major legislative enactment affecting business.

The first generation of Hastings graduates were in on the ground floor of this development. Some of the large firms that now dominate the San Francisco bar were founded by them. Pillsbury, Madison, and Sutro began with the one-man practice of an eminent advocate of the late nineteenth century, Evans S. Pillsbury. 
In 1889, Pillsbury hired Frank Delino Madison as his clerk. Madison received his LL.B. at Hastings in 1892, and in 1896 was taken into partnership by Pillsbury. From 1896 to 1898, Pillsbury's son, Horace Davis Pillsbury, attended Hastings, was admitted to the bar in 1898, married a Boston girl, and entered his father's firm without taking the LL.B. The firm was quick off the mark in appreciating the opportunities afforded by American acquisition of the Philippines, and from 1901 to 1904 young Pillsbury teamed up to practice in Manila with Oscar Sutro, who had been at Hastings with him (and who also did not take the LL.B.). In 1904, the firm in San Francisco became Pillsbury, Madison, and Sutro. It expanded rapidly under Horace Davis Pillsbury, Madison, Oscar Sutro, and his brother Alfred Sutro, '94. Pillsbury was heavily involved in utilities practice, particularly for Pacific Telephone and Telegraph and its subsidiaries.

Out of similar small beginnings evolved the firm of Brobeck, Phleger, and Harrison, which had a largely Hastings origin. Peter Francis Dunne, '81, began alone in the general practice of the law. For awhile he was in partnership with Henry Clay McPike, '81, and by 1904 he was general counsel for the Southern Pacific Railroad. In 1911, Dunne joined Alexander F. Morrison, '81, and William I. Brobeck, '92, who had been in partnership with Judge W.B. Cope (a Hastings Director) until the latter's death in 1909. The new firm, Morrison, Dunne, and Brobeck, lasted until 1924, when Dunne and Brobeck-Morrison having died in 1921took in Herman Phleger, who had gone to Harvard Law School after graduating from the University of California and practiced in the firm from his admission to the bar in 1915. In 1925, Maurice E. Harrison, J.D. Boalt, '07, joined the firm as he left the Hastings deanship. Dunne formed a new partnership which lasted until his death in 1933, and hence from 1925 the firm was Brobeck, Phleger, and Harrison. No less distinguished than these firms was Heller, Ehrman, White, and 
McAuliffe, which began as Heller, Powers, and Ehrman in 1906. Emmanuel Heller, '89, and Frank H. Powers, who had been admitted after private study in 1889 , went into partnership in 1896; Sidney Myer Ehrman, '98, joined them in 1906 after six years with W.S. Goodfellow and Garret W. McEnerney. With the addition of Jerome B. White, '06, and F.M. McAuliffe, who prepared in a law office, the firm has borne its present name since 1921 . Hastings men were behind other firms which have not preserved quite so unbroken a continuity in name as the firms above but which were of similar size and equal standing and importance. McCutchen, Olney, Mannon, and Greene, which was renowned in the 1920s and '30s, was driven by the mainspring of Warren Olney, Jr., '94, who was on the Hastings faculty from 1895 to 1901 , Director from 1910 until his death in 1939, and justice of the California Supreme Court from 1919 to 1921. Olney also was general counsel of the Western Pacific Railroad for a number of years. William H. Orrick, '03, had been secretary to the California Code Commission, 1907-08, and was a founding partner of a major firm of attorneys known today as Orrick, Herrington, Rowley, and Sutcliffe. Orrick died in 1976, but his name and the Hastings tradition are carried on in the firm by his son and surviving partner, Andrew Downey Orrick, '47. Indeed, a measure of how recently the great firms connected with the first generation of Hastings graduates still enjoyed their presence as well as felt their mark is afforded by the reflection that the deaths of William Orrick in 1976 and of Sidney M. Ehrman in 1975 robbed their firms and Hastings of the company of distinguished men, fathers of their firms, sons of Hastings.

From its founding in 1872, there has been a distinctive link between the San Francisco Bar Association and Hastings, for long more intimate and more pronounced than the association's relationship to any other law school. The first three presidents of the association, from 1871 to 1889 , were founding-Directors of Hast- 
ings: Joseph P. Hoge (the prime mover in setting up the association), W.W. Cope, and Samuel M. Wilson. The president of the association, 1890-91 and 1894-95-the only two-term president-was Edward Robeson Taylor. Director Robert Y. Hayne was president, 1896-97. Gaining the laurel of another first, Charles William Slack, '82, was the first Hastings graduate to be president, 1900-01. Characteristically, Slack was for the association as he was for Hastings a shaker and mover. By the turn of the century, the association was an exclusive and very comfortable, in every sense of the word, club of aging lawyers; its denizens were better known for their success, wealth, and paunches than for any hot enthusiasm for professional or civic causes. Slack's immediate predecessor, William H. Fifield, 1898-99, epitomized the membership: fifty-five years of age, well-practiced, and trained in a law office. Judge Slack was in vivid contrast: aged forty-two, recently off the bench and out of the Hastings deanship, and a graduate of a law school (the first president of the association to be so). Slack began the campaign for the reform of the association that bore fruit in the next presidential tenure, that of Warren Olney, a graduate of the University of Michigan Law School who sent his son and namesake to Hastings. Slack was senior vice-president under Olney, and they were aided and abetted by the two junior vicepresidents, Henry Eickhoff, LL.B. Columbia, '75, and August Comte, Jr., an A.B. from Harvard and successful probate lawyer. The reformers increased the number of committees of the association, establishing one on grievances aimed at self-policing of the bar; pressed for more members, and by abolishing the initiation fee and reducing the monthly dues, attracted younger lawyers and doubled the membership in a couple of years; began agitation for more superior court judges in the city and county (accomplished in 1903); appointed a permanent paid secretary to give continuity to program and to administer the quarters and library of the association. The recent historian of the associa- 
tion says that " 1901 and 1902 are probably the two most important years of the Association's existence..." by virtue of these reforms. ${ }^{11}$ The permanent secretary, George J. Martin, from his appointment as registrar of Hastings in 1910, provided a continuing nexus between the association and the College until his death in 1936. Walter B. Cope, a newly-appointed Hastings Director, was president from 1906 to 1908. Between 1913, when Judge Charles A. Shurtleff, '82, became president, and 1941 when the tenure of Harry S. Young, '07, ended, of the association's 13 presidents, eight were Hastings graduates (Shurtleff, Beverly L. Hodghead, '91, Warren Olney, Jr., '94, Randolph V. Whiting, '95, four of them in succession, from 1935 to 1941: Arthur W. Brouillet, '11, John H. Riordan, '09, Hartley F. Peart, '01, and Young) and one more, Maurice E. Harrison, not a graduate, was a former dean. Hastings has not done so well since: Bar Association Presidents Wallace Sheehan, '20 (1951-52), A. Brooks Berlin, '24 (1956-57), Ben K. Lerer, '33 (1963-64), and Charles H. Clifford, '56 (1972-73) were graduates of Hastings, and E. R. Wallach (1975-76) is an adjunct professor of the College, very active in reinvigorating the old Hastings-Bar tie. Another measure of how intimate that tie was in the quarter-century before World War II is indicated by the fact that in 1924, of the officers and members of the association's standing committees, 17 were without a Hastings connection, 10 were Hastings graduates (including the president, Hodghead, the junior vice-president, and treasurer), and three past or present faculty members. When the association again faced a crisis of aging, it was another ex-dean of Hastings, Maurice E. Harrison, who led the way to resolving it by creating the Barrister's Club in 1927, a club within the association to attract younger lawyers. In the 1920s, nearly every member of the Hastings faculty was a member of the association, many were in it in the 1930 s, but very few have been since the onset of the 65 Club. For a number of reasons, perhaps not least the nonmembership of the 
faculty in the association, the relationship between Hastings and the San Francisco Bar Association became very chilly in the 1940s and 1950s.

By Hastings' Golden Jubilee in 1928, hardly a superior judicial bench in California had not borne the weight of a Hastings lawyer. At one time or another, and increasingly, Hastings men were superior court judges in most of the better populated counties of the state. Starting with Slack in 1891, the San Francisco Superior Court was heavily weighted with Hastings alumni: Slack, '82, William R. Daingerfield (no LL.B.), Rhodes Borden, '84, Edmund P. Mogan (no LL.B.), John J. Van Nostrand, '96, George H. Cabaniss, '84, Marcel Cerf, '00, Adolphus E. Graupner, '97, Daniel C. Deasy, '97, Edward P. Shortall, '96, Timothy Fitzpatrick (no LL.B.) - with the heaviest concentration of them first serving between 1908 and 1914. Thomas E. Haven, '90, William H. Waste, '94, John F. Tyler, x'87-88, took seats as justices of the district court of appeal, First Appellate District between 1918 and 1921; Frank G. Finlayson, '85, went from Los Angeles superior court to the presiding justiceship of Division 2 of the Second Appellate District in 1919; Emerson J. Marks, '99, in 1929 became a justice of the Fourth Appellate District. Matthew I. Sullivan, $x 1878-80$, in his brief tenure in 1914 as chief justice of the California Supreme Court, was the first Hastings alumnus to attain that august position, but Alexander Melvin, '92, had become a justice in 1908 and served until 1923. Frank M. Angellotti, '82, succeeded Sullivan as chief justice in January 1915 and served until 1921. Warren Olney, Jr., '94, was a justice, 1919-21, and in the latter year both Charles A. Shurtleff, ' 82 , and Waste became justices, Shurtleff sitting until 1923. Waste became chief justice in 1925. Finlayson moved from the District Court of Appeal to the Supreme Court in 1927. It is fair to say that in the early part of the 1920s, when the California Supreme Court delivered its judgment, the hand that wrote it had probably first begun to grasp the law in a Hastings classroom. 
Within its own walls, Hastings manifested its satisfaction with its graduates. By the golden jubilee year of 1928, six of the nine Directors, including the ex officio president of the Board, the chief justice of California, were Hastings graduates: Chief Justice William $\mathrm{H}$. Waste, '94, three members of the renowned second class who had all held judicial office (Charles William Slack, '82, Charles H. Shurtleff, '82, and Frank M. Angellotti, '82), Warren Olney, Jr., '94, and Sidney M. Ehrman, '98. William B. Bosley was LL.B. Yale, '94, Allen L. Chickering had been at Harvard Law School, 18981900, and the representative of the Hastings line, Joseph Fiske Catherwood, was not a lawyer. Chickering made amends for his youthful transgression in going to Harvard by sending his son, Allen L. Chickering, Jr., to become a Hastings LL.B., '33. With the exception of Catherwood (who took the seat of Hoyt Hastings, deceased, in 1926) and Chief Justice Waste (seated in January 1926), the jubilee year Board was the Board that Maurice E. Harrison had to deal with. Harrison established an excellent working relationship with the Directors. At the outset, the Directors invited him to be present at all their meetings, thereby initiating a practice that obtains to this day. The Directors' common Hastings background and affection for the College, Slack's and Olney's previous experience as faculty, and the high legal competency of the Directors made them well-disposed toward Harrison, who built upon their favor by being a persuasive and assiduous administrator. He was actively involved in the San Francisco and California State Bar Associations and he enjoyed friendly relations with other California law school deans, not least his old teacher and mentor at Boalt, Orrin Kip McMurray. He was imaginative and activist in the deanship; the Board could afford to overlook both his lively practice at the bar and his oft-repeated desire to quit Hastings.

Harrison was a whirlwind compared to Taylor. $\mathrm{He}$ was no sooner in office than he took a hard look at 
faculty and curriculum and persuaded the Board to make some changes. Assistant Professor Thomas A. Thacher, who had not returned from his leave for wartime service, was let go, his course shifted to that workhorse, James A. Ballentine. George L. Bell, in a similar situation, was also let go, and Robert L. McWilliams, a Boalt graduate, was appointed to teach Trusts. William M. Simmons, who succeeded Harrison as dean, was added to the faculty as an instructor in Public Corporations in 1920. Promotion for merit was given Richard C. Harrison, from assistant professor to professor. In 1921 , a 10 percent across the board faculty salary increase was granted, the first general salary raise since 1899. Registrar George Martin was raised from $\$ 27.50$ to $\$ 35.00$ per month for his part-time, but demanding, job. The raises were really insufficient, but they were good for morale. The dean, armed with a resolution of the Board, discouraged Hastings faculty from "giving instruction in law schools of inferior standing. ..."12 This provision was aimed at Robert W. Harrison, who also taught at San Francisco Law School from 1907 to 1929; McWilliams was dean of the same school from 1924, and did not resign from Hastings until 1928. In 1922, Harrison secured the appointment of a special lecturer to give four lectures in legal bibliography. And it was Harrison who first seriously undertook the building up of the College's own library as a matter of policy, securing a number of gifts of books, and with Slack's encouragement undertaking systematic purchase of reports, law reviews, and the Corpus Juris.

With the appointment of Sidney M. Ehrman, '98, to the Board in 1922, a veritable "angel" was found for the College. Ehrman regularly provided the money from his own pocket for the dean to attend the annual meeting of the Association of American Law Schools, until 1927, when Hastings was dropped from membership in the AALS. Ehrman's munificence was aimed at strengthening the College's scholarly reputation. He established a fund to bring a distinguished academic 
lawyer to give an annual lecture series. The first lecturer, in April 1925, was the eminent dean of Northwestern, John W. Wigmore, who gave five lectures on "The World's Legal System." Ehrman crowned his generosity with the establishment of the College's first chair, the Isaias W. Hellman Professorship (in honor of Mrs. Ehrman's father). The $\$ 30,000$ gift was given in 1925 , and the first incumbent was the new dean, William M. Simmons. The professorship has remained attached to the deanship from its creation.

College finance did not present a major problem during Harrison's administration. The registration fee was raised from $\$ 40$ a year to $\$ 50$ in 1922 , and to $\$ 75$ in 1925. The Directors' solid and careful investments of some years brought a modest yearly income. This nestegg was much increased by the investment of the Hellman endowment, the income from which paid about one-third of the dean's salary until the Great Depression. From 1911 to 1935 , the state appropriation remained at $\$ 18,800$ for the biennium, or $\$ 9400$ per annum. The $\$ 2400$ beyond the $\$ 7000$ specified in the 1878 act was for rental of quarters, first in the new City Hall, and from 1923 in the newly-constructed State Building. In 1921-22 a supplemental appropriation of $\$ 3000$ was made for new equipment for the State Building quarters. The steady rise in enrollments-1919 (34), 1920 (89), 1921 (89), 1922 (114), 1923 (117), 1924 (112), 1925 (150) - coupled with the increased registration fee, provided the necessary revenue to allow the College to do better than break even.

The figures above indicate how hard hit the College was by the First World War. With "Normalcy," Hastings shared moderately in the general increase in the number of people going into law. Maurice Harrison suggested to the Class of 1920 that it undertake the foundation of an alumni association. Henry Eickhoff, Jr. and Eugene D. Bennett of that class joined a number of eminent graduates, including William Colby and his wife Rachel Vrooman, Slack, Shurtleff, and Angellotti 
in the enterprise. Eickhoff was very much a leading spirit; in 1924 he gave a generous gift of books and periodicals to the College. The Alumni Association was formally organized at a luncheon meeting in August 1922 during the ABA convention in San Francisco. Sidney Ehrman, the principal speaker, made a strong plea for the creation of an endowment fund for "financially the poorest first-class institution of its kind."13 Though Ehrman by his own munificence blazed a bold trail, none followed him down it. Yet the mere continued existence of the Alumni Association had promise for the future; it served as a source of continuity and a focal point around which the college spirit and college pride that infected Hastings students during the 1920s could express itself.

Hastings could hardly aspire to the traditional halls-of-ivy collegiate tradition of American higher education which predominated in the 1920s, no less in California (where ivy was not encouraged) than in the East where the ideal (and the ivy) had taken root. Bereft of campus, a tenant-at-will at one end of one floor of a badly designed, architecturally pretentious government building set down in an urban viscus surrounded by areas already showing signs of inexorable decay, Hastings was not even a suitcase college-it was a lunch-box college. Its students commuted considerable distances, by trolley from the other parts of the City as far out as the Sunset District, by ferry from the East Bay. Between 8 and 11 in the morning, Monday through Saturday, there was an educational institution in action; as the sun reached its highest altitude, the institution melted away. Faculty went back to their practices. Students went to work in law offices, banks, shipping companies, brokerage houses, and stores where they gained the wherewithal to continue study. There was only one scholarship at Hastings, no loan funds, no means of support other than what the student had or could acquire. Estimates vary, but probably nine out of ten Hastings students in 
the 1920s worked for a living. A constant refrain in student memories of the period was the heavy burden of work on the job, the sandwich grabbed on the run, long hours behind a desk, the tiring trip home at the end of the day. Study was sandwiched in at odd moments; you could always tell a Hastings student on the ferry or the trolley at rush hour because he had his nose in a casebook. There was little free time; Hastings students didn't yet qualify for inclusion in Thorstein Veblen's "leisure class." Saturday afternoon at the ballgame was a major recreation. One lady graduate of the Class of '29 recalls that her "most poignant memory of entering Hastings was the leaving of the swimming pool at UC Berkeley." ${ }^{14}$ The YMCA wasn't too far away from the State Building (and it still s 'rves Hastings students for relaxation), but classes all morning and 1-5 pm at work left little time even for a quick dip.

In this unpromising ambience a social life flourished. Like everything else about Hastings of that day, it was sandwiched in-somewhere-between everything else. Five enterprising, aspiring Chrysostoms (including Edward Mancuso, '29, who would long serve as San Francisco's Public Defender) founded the Eunomathia Debating Society in 1927 to hone forensic skills. This was the latest of six student societies in which the College's social life centered. The four fraternities and one sorority were professional societies, not residential organizations, and with Eunomathia were the principal formal vehicle for student activities and student camaraderie. There was no hazing. The societies were not very exclusive. Some 60 percent of the students belonged to them in the later 1920s. The oldest, the Pomeroy Inn of Phi Delta Phi, was established in 1883. Phi Alpha Delta's Jackson Temple Chapter was set up at Hastings in 1911. Sigma Delta Kappa and Sigma Nu chapters both made their appearance at Hastings in 1926. Because there were so few women students, Kappa Beta Pi sorority (founded 1924) was the 
least exclusive of these student groups. The Greek societies put on "affairs," very formal dinners given at exclusive hotels and country clubs. Since most of the students were single (this was an age when one "got an education and got a job" before embarking on the marital ship), these affairs were well attended and always looked forward to with great pleasure. The Volstead Act notwithstanding, gin usually ended up in almost everyone's water glass before the evening was over. The graduating class had a "stag dinner" to which the women students were welcome, provided they could bear up under being the cynosure of all male eyes. The jokes were never particularly risqué. The one truly male-only affair was the annual graduation "smoker," which was sometimes noisy but not wild, since the dean presided over it with an eagle eye. The Greek societies were also responsible for creating and maintaining a student government, complete with officers, the principal function of which was to advance "school spirit." Grievances were either few or not widely felt. In March 1928, Hazel Utz, '29, was elected the first woman student body president. Hazel Utz Lancaster claims that it was all a joke, and that she turned the office over to Frank Parker, '29, her opponent at the hustings, who had more time and money than she to devote to the office. However, the newspapers' announcement of her election were widely read and brought a congratulatory letter from Clara Shortridge Foltz.

The moot court activity connected with the upper classes and studying for examinations created some camaraderie and a degree of intimacy among students. A certain formality obtained otherwise, and students addressed each other as Mister and Miss. By the third year a class was on first-name terms, and the anticipation of parting gave a special urgency to amity. Strong friendships were forged that lasted for lifetimes. A class was small enough for every member of it to know every classmate. It is amazing how well, a half century later, alumni can recall something about most of their fellow 
students. The recurring theme among students from this period is the sense of common commitment to learning the law and preparing to practice the law. Some saw the Hastings experience as a matter of business, considered Hastings to be a "business organization" (and a good one) directed to a business end. All believed that nothing was lost by the want of social frills and lack of ivy-collegialism. This picture of the professionalism of the students might have gained something over the course of long professional careers, from the vantage of fond retrospect. But a genuine satisfaction was more apparent than dissatisfaction. The students respected their teachers for their professional practitioners' competence. The students were convinced that they were learning the law. They did not feel compelled to voice the trite phrase that they were learning "how to think like lawyers." This notion, a creation of the Langdellians, might once have been a significant conceptual breakthrough in legal education, but it has always eluded analysis and perhaps been pitched too high as a claim to stand the test of reality. Hastings students were convinced that they were learning how to practice the law, and the law-office work that most of the students undertook during their three years at Hastings seemed to them time well spent. There were immediate benefits that derived from their jobs, such as access to the office library, which supplemented the woeful lack of books in the College library and reduced dependence on the overcrowded San Francisco Law Library. But above all, there was the experience of putting into practice almost daily, under the eye (always benevolent in retrospect) of the "boss," what was being learned in the cramped and airless classrooms at Hastings. That experience, with the formal class work, added up to a sound legal education. The subsequent success of most of those young men and young women provided real testimony to the excellence of the total Hastings education.

The students from those "Roaring Twenties" recall 
Hastings with affection and pride. They were soon to taste the bitter, hard years of the Great Depression; it took less than a decade for the 1920s to appear as the Golden Age. Yet who can deny that it was indeed the Golden Age? "Youth, what man's age is like to be doth show/ We may our ends by our beginnings know." 15 Good youths, good ends: Aurea Aetas. 


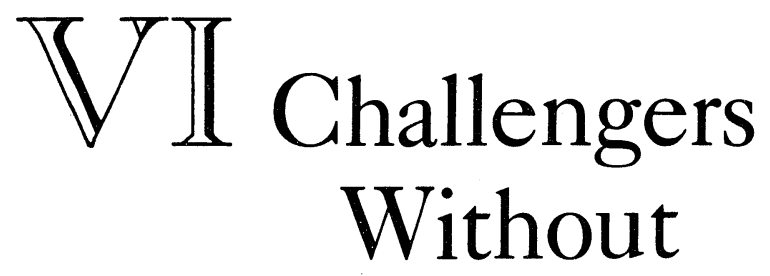

$\mathrm{O}_{\mathrm{N}}$ the whole, the fortunes of higher education in America have followed the country's economy. The 1920s saw a bullish economy and a relative upsurge of prosperity for colleges, universities, and specialized professional educational institutions; the 1930s were bearish, and for institutions of higher education very nearly catastrophic. In this, though, as in other instances, Hastings College of the Law was something of a deviant from the mean. The 1920s brought very little real financial betterment for the College. On the other hand, the 1930s found Hastings in a less parlous position than most other law schools on the West Coast, or for that matter in the country as a whole. This is not to underestimate the threat of the Depression, only to emphasize that Hastings weathered a prolonged tempest that sank a number of law schools and sore hurt others for a long season. It would be satisfying to be able to say that it was the dean's superior administrative skill and the Directors' assiduous and devoted attention to the needs of the College that enabled the College to survive so well. However, this was not entirely the case. Dean William M. Simmons (1925-40) and the Board of Directors were not unmindful of their responsibilities or ineffectual in discharging them, but their efforts were not extraordinary or extraordinarily successful. Rather, Hastings continued in what today's academic adminis- 
trators term a "steady state," that is, no significant growth or palpable erosion took place in faculty numbers or normal expansion of program. Hastings grew in numbers of students only slowly over the 1920s, enjoyed a sudden, even spectacular, increase in the early 1930s, and managed to maintain a good enrollment until the end of the Terrible Thirties. During the period between the wars, the College faced vigorous challenges from other law schools, some its peers and others its inferiors, many of them close to home; it was attacked by outside interests, some national, bent on the reform of legal education in America; it was treated like a stepchild by the University of California. What saved Hastings College of the Law was its clientele, those students who in good times and bad had no other alternative for the acquisition of a legal education. They kept faith with faculty and Board when all others seemed set against the College. No noble motive need be ascribed them; enlightened self-interest and necessity set them on that course. Yet they remained proud of Hastings, and in the College's first bitter taste of adversity the students were supportive and committed. As the Witch in Macbeth prophesied:

Though his bark cannot be lost,

Yet it shall be tempest-tost

[I.iii.25]

Hastings sailed on unsinkable, thanks in greatest part to the loyalty of its students.

On May 1, 1925, the Board of Directors appointed William Marvin Simmons Dean of Hastings College of the Law, and conferred upon him the just-established Isaias W. Hellman Professorship of Law. Simmons, forty years of age, had served on the faculty since September 1920, teaching Public Service Corporations, Conflict of Laws, Mortgages, and Pleading and Practice-all second- and third-year courses, two of them "new" courses that had come into American law school curricula only since the eve of World War I. As 
dean, he taught first-year Property (course II, Real Property), as well as the more specialized upperclass courses.

The appointment of Simmons constituted a break with tradition and proved to be a precedent. The search committee that recommended his appointment consisted of Directors Sidney M. Ehrman and William B. Bosley and Dean Maurice E. Harrison. Never before had a non-Director served in this role, and indeed, never has one since, because Harrison was the last dean who did not die in office. More significantly, Simmons was the first of an unbroken succession of deans who were appointed from within the faculty and virtually handpicked by the preceding dean. A close friendship developed between Harrison and Simmons. They were about the same age, of similar personality, had gotten to know each other in San Francisco practice, and were gentlemen of genuine cultural interests. Simmons, though he had no formal rank other than that of assistant professor, appears to have been Harrison's strong right arm. It was natural for a committee of which Harrison was a member to move for Simmons' appointment as dean. What is most striking about the appointment is that Simmons was to be paid the relatively large salary of $\$ 6000$ (a generosity made possible by the Hellman chair), and while he was to hold it during the Board's pleasure, there was no explicit prohibition against his taking part in outside activities, including practice. In fact, Simmons was also the first in an unbroken succession of deans who really were full time, without significant outside activity save of a temporary or voluntary nature, who devoted their entire waking hours to the operation of the College. This was a departure which has never been deviated from since.

Simmons was an Iowan and a graduate of a small Iowa liberal arts college, Cornell College at Mt. Vernon. He received his LL.B. at Harvard in 1911, was admitted that same year in California, and practiced first in the legal department of the Western Pacific Railroad before 
going into partnership in a private practice in the City. In May 1917 he answered the call to the colors, arrived in France with the AEF, went into action in the early engagements, and was wounded. For Bill Simmons, as for so many other young Americans of his day, the peculiar horrors of the Great War on the Western Front left an indelible impression-rarely did he fail to give a sobering and moving homily to a first-year class at Hastings on the dreadful wastefulness of war. In 1919 he was discharged with the rank of captain. Before returning home, he had, like a number of young American soldiers who were at loose ends after the Armistice was signed, availed himself of the Army's offer to finish out his service in a European university for a few months of study (and good fun) in early 1919. Some preferred the Mediterranean blandishments of the Université de Montpelier, but Bill Simmons went to Oriel College, Oxford, sharing rooms with four other Yanks. With his interest in literature and history, young Simmons found the sojourn enjoyable and broadening. He returned to practice in San Francisco in 1919, and took up the Hastings instructorship shortly afterwards. An extremely diligent and hardworking teacher and administrator, he kept an open door at all times to his faculty and students. He never married, and like many academic bachelors, he found his college a substitute for a household. His very presence provided continuity to the College. Everyone stood in awe of his broad learning and cultivated conversation. He was a dapper dresser, always dignified and soft-spoken, but without a trace of arrogance or side. "Elegant" is the word that is most often used to describe him by those who remember him. He had a piercing eye, a strong, even stern gaze that was sometimes unnerving, especially to one with a guilty conscience. He was eminently fair and just. He was not a particularly inspiring teacher. Always competent, he did not brook any nonsense in class; a student who was one minute late arriving for class found the door locked. Over the course of his fifteen years as dean, Simmons 
became a beloved figure. His successor, who was not given to excessive praise of any other mortal being, delivered a eulogy after Simmons' early death at fifty-five that was genuinely deepfelt and moving.

The relations of Simmons with the Board of Directors were harmonious and even warm. The Board underwent very little change during his tenure, and Simmons managed to obtain what he wished from it. Bosley, Ehrman, and Slack were the commanding Directors, and they held Simmons in high esteem. The Board delegated almost all responsibility to the dean; there is no hint that they ever saw cause to regret it. Adversity, the challenges from without the walls, drew dean and Board closer together.

By temperament, Simmons was not a fighter. $\mathrm{He}$ was almost too academic, cultured, and dignified. The Biblical adage, that the gentle answer turneth away wrath, was invariably followed by Simmons in any controversy in which he found himself (always regretfully) engaged. Perhaps such gentleness, such unstudied civility, was a good form of defense. The College's detractors should, one senses in retrospect, have been made to smart some. That was not Simmons' way. Still, he never gave a handle to the detractors. Never was his personality caught up in battle. Never was his image confused with that of the College. In the process he maintained internal peace, a certain equanimity of routine that allowed the College to function very largely unbuffeted by the waves that were washing against it. He was neither ignorant of nor insensitive to the danger. He was well aware of how seriously the challengers were eroding the College's position and reputation. But he recognized the financial limitations within which the College must function, and believing discretion the best part of valor, he worked steadily from within at least to maintain the College as an institution providing sound training for the practice of the law. It was a fulltime job. It was an onerous and killing task. The repeated blows he took, thereby shielding the College 
from them, led him to an early grave. A week after his sudden death from a massive stroke in July 1940, the Board expressed its

profound regret for his untimely death, its appreciation for the fine service that he has rendered the College and his country, and for the consequent loss to the College.... ${ }^{1}$

The Board rightly mourned the passing of a good and faithful servant.

Between 1878, when Hastings came into existence, and 1920, 99 law schools had been founded that were still in operation in 1920. These law schools virtually covered the country. They ranged from prestigious major university law schools through law schools of smaller universities, individual colleges of law, and some so-called "universities" that were only law schools, to part-time or evening law schools. During the same period, about half as many law schools as still existed in 1920 had come and gone, most of them disappearing without a trace, a very few of them merged with other essentially proprietary schools or else absorbed by a state or private university. One result of the proliferation of law schools was the rapid disappearance of the old method of legal training, "reading law" in the law office, especially in the more urbanized areas of the country. Significantly, by the second decade of the twentieth century, urban bar associations, many state bar associations, and the American Bar Association had come to be dominated by younger lawyers, and the majority of these Young Turks were law school graduates. About 1910, the American Bar Association (which was as old as Hastings) began to manifest considerable uneasiness about the competence of practicing attorneys and the quality of legal education. These were, of course, closely linked, complementary concerns. The disquiet grew less from any real perception of the failings of the legal profession than from recognition of how methodically, effectively, and advantageously, in terms of both professional probity and profits, the American Medical 
Association was organizing doctors and influencing medical education for the better. The Bar Association's response to the problem was vague, and directed toward restructuring the Association, stimulating greater activity in its functions, increasing membership, and exploring means to assure a higher minimum standard of professional competency both in legal education and at the time of admission to the bar. Rather surprisingly, the $\mathrm{ABA}$ was not as concerned with the inadequacy of law-office training as with the shortcomings of law school programs. Part of the explanation for this lay in the general acceptance of the imminent disappearance of law-office training; little was to be gained by flogging a dying horse. Part, probably the larger part, of the explanation lay in the efficacious intervention of that first great private foundation zealous in public causes which was prototypical of all those institutions which have become such a characteristic part of American learning and culture, the Carnegie Foundation for the Advancement of Teaching. To a foundation of such august interests, law-office training was beneath notice.

The Scottish-born Pittsburgh steel-magnate of purposeful eccentricity and enormous wealth, Andrew Carnegie, established the foundation with an endowment of $\$ 10,000,000$, and in 1906 appointed Henry S. Pritchett its first president. Carnegie was a strenuous advocate of technological education; himself deprived of virtually all formal education, he was a self-made capitalist whose philanthropy was consistently devoted to education, in part from the yearning to accord to others what he had been denied, in part because he recognized more clearly than anyone of his generation that education was the foundation of economic growth in the industrial society. In 1900 Carnegie endowed the Carnegie Institute of Technology in his home bailiwick, Pittsburgh, to give practical expression to his conviction. Shortly afterwards, he warmly supported discussions for merger between Harvard and a neighboring undergraduate technical college with a high-sounding name, 
the Massachusetts Institute of Technology. The promerger forces at both institutions envisioned MIT as becoming a graduate school of engineering, part of Harvard. The president of MIT from 1900 to 1906, against an overwhelming negative vote of his faculty, the student body, and the almost violent sentiments of the college's alumni, almost pulled off the merger. Only the judgment of the courts dashed the union by preventing MIT from selling its existing property to pay for new buildings to be constructed on Harvard property. The MIT president had argued that:

Everything points to the fact that we are in a transition stage, and that a new step must soon be taken in this country in technical education: either the courses must be lengthened or some of the strongest schools become graduate schools, or some other means must be taken to meet the changing demands for education and for research in technical schools. ${ }^{2}$

MIT President Henry S. Pritchett may have lost the argument, despite such persuasive perspicacity, but he had won the friendship and admiration of Andrew Carnegie. By appointing Pritchett president of the Carnegie Foundation, Carnegie gave him the position, the support, and the opportunity to attempt to work his educational revolution on a national scale.

Pritchett graduated from a mediocre college in his native Missouri in 1875. But he received a thorough grounding in mathematics and adequate training in astronomy. Early service as a government astronomer, including a great deal of field-observation, brought him a chair and the directorship of the Washington University observatory in St. Louis in 1883. In 1894 he entered the ranks of that new breed of American academics who in his generation dominated American science; in that year he received the Ph.D. from the University of Munich. This was formative of his approach to education. The "new professor" was to be not an autodidact, but a research scholar meticulously trained to the highest technological perfection possible. Dr. Pritchett in 1897 became director of the U.S. Coast and Geodetic 
Survey and reorganized the old Federal Bureau of Weights and Measures into the truly scientific research establishment that still exists, the U.S. Bureau of Standards. As president of the Carnegie Foundation, he recruited his own kind. His chief assistant was a young graduate of Johns Hopkins (the American "German" university) and Harvard, with a year of postgraduate study at Berlin under his belt when he joined the enterprise in 1908: Abraham Flexner. Flexner, too, was a Westerner, a product of that remarkable community of long-established Jewish merchants and intellectuals in Louisville, Kentucky, which also produced Justice Louis Brandeis. Flexner was a Classicist whose uncompromising fidelity to modernistic German educational notions appeared to his fellow Classicists to amount to apostasy. He pioneered the abolition of Classics in American high school education in a New York experimental school established in 1917 under his influence; Greek Furies descended upon him! A further frontier, Colorado, produced Alfred Zantzinger Reed, whose father was a country doctor prepared to finance a Harvard and Columbia education for his son. Reed received his Ph.D. in politics at Columbia in 1911; in 1913, he joined the Carnegie staff with a special interest in legal education. Pritchett, Flexner, and Reed had a great deal in common. None of them had been born into the Eastern intellectual and cultural establishment, but all were products of German higher education or its American imitators, the imitators being confined almost entirely to the Eastern seaboard. None of them had any real classroom experience in implementing German postgraduate educational methods. Pritchett had come closest while at St. Louis, but Washington University was not an adequate forum for innovation in the German mode. Neither Flexner nor Reed had taught at the university level; their teaching experience had been at the high-school level, and Reed spent the eleven years preceding his Carnegie debut as a private tutor in New York City. None of them saw the classroom again after joining Carnegie. 
Flexner delivered the Carnegie Foundation's first great bombshell in 1910 in the renowned Bulletin no. 4, Medical Education in the United States and Canada. ${ }^{3}$ The manifesto, crammed with facts, exposed every weakness in contemporary medical school education. It received great publicity; its effect was considerable. The AMA took it to heart, even though Flexner was not a physician. Encouraged, the foundation decided to turn its pitiless light on the legal profession. Reed, "whose previous training had been acquired in the field of politics or government, rather than in that of its technical subdivision, professional law, "4 was chosen to illuminate the dark recesses of Justitia's untidy house.

Reed's self-description, quoted above, is revealing. Law was merely a "technical subdivision" of government. Therefore, to borrow an old legal maxim, Majus continet minus (The greater contains the less), Reed could consider himself qualified to inform the legal profession what it must do to reform itself. Also, the use of the term "technical"-which has the effect of making the lawyer an engineer of the purer science of government-was quite in keeping with the socialscientific emphasis of the German conception of learning and knowledge. It was a concept the Carnegie savants had imbibed, represented, and intended to implement across the board in American education. Reed was very proud that Flexner had pointed the way in the medical education manifesto for the reform of all professional education. That the lawyers "might profitably learn from physicians how to improve their own system of education"5 was posited on the unquestioned assumption that the role, and therefore the training, of physicians and lawyers differed only in one significant way: there was a "public" dimension to the activities and the aspirations of lawyers that was irrelevant to physicians. The legal profession was the cradle of politicians, and in a democracy it was essential to assure all classes and kinds of people easy access to the profession to prevent the stranglehold of aristocratic monopoly. The 
perceived difference between the professions was understood to be one of degree, not of kind, and one which, with a bit of professional reorganization, could be provided for. It certainly was not so serious as to prevent the application of the perfect method, growing from the perfect education afforded by German scienticism, to the reform of legal education as effectually as it had been applied to medical education. Armed thus with the perfect method, Alfred Zantzinger Reed would be no less the Old Testament Prophet calling the chosen people of the legal profession back to probity.

There was more of Jeremiah than of Elijah in Reed. His fate was to lament the ingratitude and misunderstanding of those whom he had come to save rather than to receive the apotheosis of translation into heaven before the wondering eyes of the people whom he had delivered out of spiritual bondage! The legal profession greeted his crusade with mild interest, some derision, and considerable reluctance to fall in behind his banner. He began his jeremiad for the reform of legal education in the foundation's annual report for 1915, and maintained it in the same vehicle annually to 1925, and thereafter in the annual Review of Legal Education to 1934. His manifesto for reform appeared in 1921 as Training for the Public Profession of the Law, Bulletin no. 15 of the foundation. It was all too much like Flexner's manifesto of a decade earlier for the reform of medical education, though it was less well written, far longer, less decisive. Despite his promises and protests to the contrary, Reed failed to comprehend the force and the extent of the "public" nature of the legal profession; the blueprint was really Flexner's. More significantly, Reed advanced no major thesis for systematic development. In a work that was more a mammoth than a manifesto (420 pages of text, 49 pages of appendices), a great thread of analytical development was essential. Reed intended that the history of American legal education would furnish the line. An historian cannot quarrel with the argument that the "underlying causes that have 
made it [American legal education] what it is to-day determine also the broad lines within which future development is possible." ${ }^{\prime}$ But there was entirely too much history in the book, so much that it deserves the devastating criticism made of history, that it is only one damn thing after another. Congeries of facts and many digressions robbed the manifesto of punch. Admittedly, a subsequent bulletin (which appeared, belatedly, in 1928) was intended to cover the contemporary period in detail. However, there was too much treasure piled up here to warrant such small-change in the conclusions.

Reed argued that there were three types of law schools in existence in 1921: the school "rooted in our colleges and universities which, teaching national law by the case method, is destined to produce a minority of our actual legal practitioners, but textbooks for all"; ${ }^{7}$ the school of part-time teachers teaching full-time students essentially local law, and this without a university context or the higher admissions standards required by the university law school; the school of part-time teachers and part-time students, otherwise hardly distinguishable from the type immediately preceding. A fourth school, with a program of less than the three years full time or four years part time that obtained in the three foregoing types still existed but was, he prophesied correctly, going to disappear. Grudgingly, he accepted the political and social necessities for these three types, albeit his ideal was the first type, reformed to be even more rigorous. Reed saw no way of getting rid of the part-time (evening) school responsive to the individual and community "demand that participation in the making and administration of the law shall be kept accessible to Lincoln's plain people." 8 To solve the problem of how to protect the consumer of legal services from incompetent practitioners, he proffered the sensible suggestion that all three types of schools be encouraged to attain their optimum potentials for training, and added the quixotic suggestion that the legal profession be transformed into a "differentiated profession" of a 


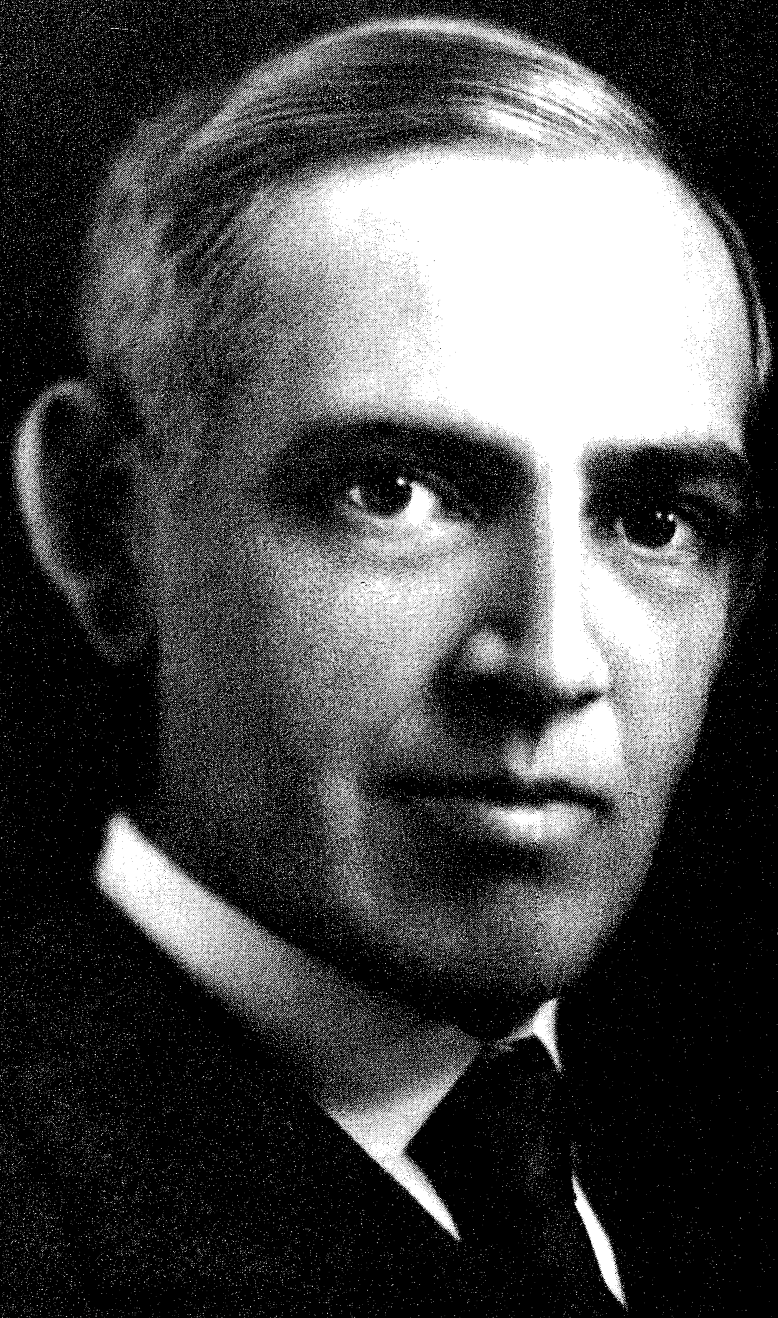

Maurice Edward Harrison

(Courtesy of Mrs. Donald B. Campbell) 


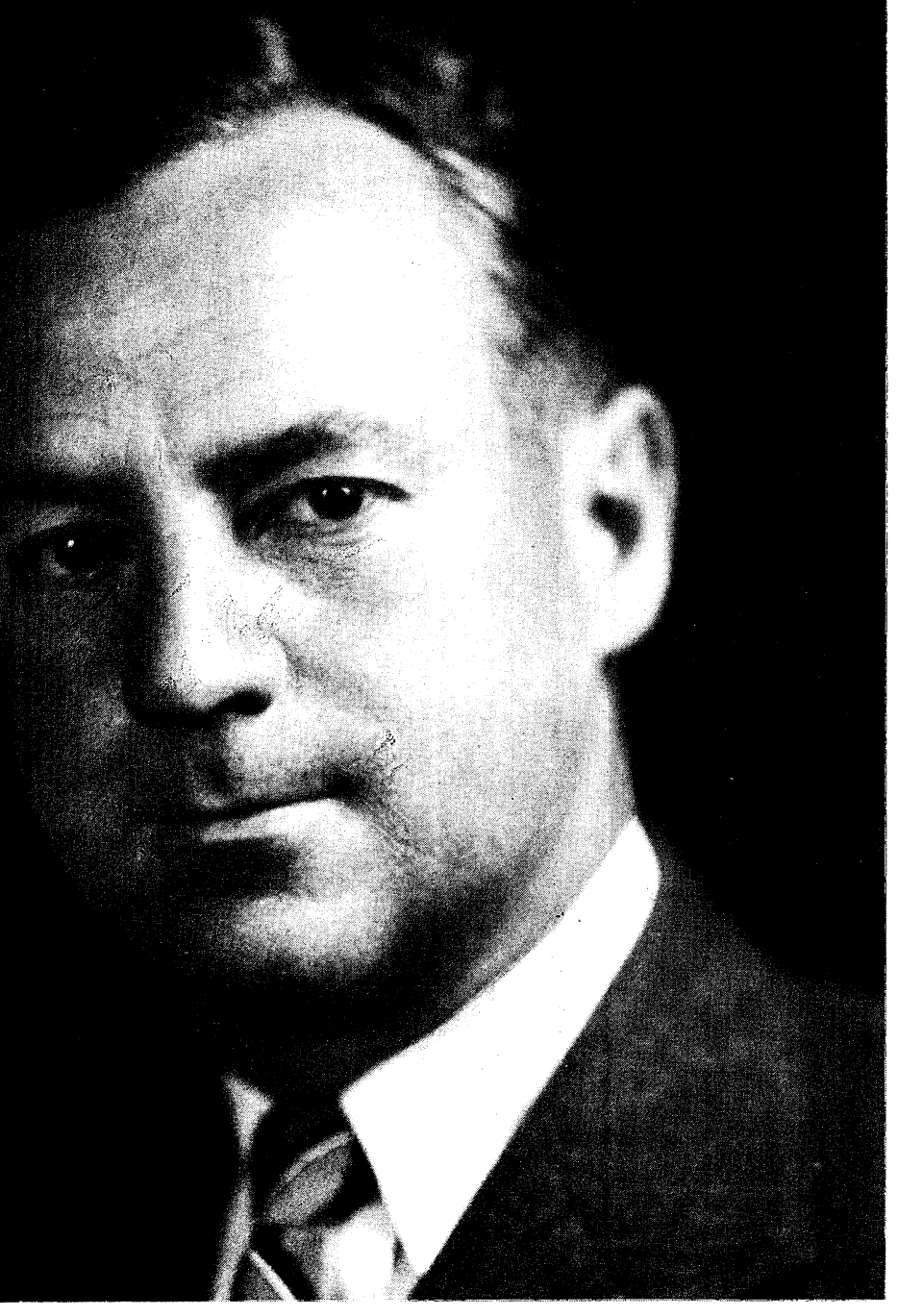

William Marvin Simmons

(Courtesy of Miss Juanita M. Olsson) 
"functionally divided bar," in which differentiation and function would be determined by the type of law school from which the lawyer came. The best law schools, the university law schools, would produce graduates prepared to practice in any aspect of law (there was the hint of specialization in such practice); the products of the "superficial schools" would be fit (and fitted) to trial work, conveyancing, probate matters, and criminal law only. Though he did not say so explicitly, Reed had in mind the English example of a bifurcated profession. The business left to the product of the poorer education would be that of the English solicitor, assuming trial work to mean advocacy in inferior courts. What Reed overlooked was that in England, though professional education for the barrister and the solicitor was different, the standard of legal training required for each was roughly the same; if anything, perhaps more rigorous for the solicitor. Reed's proposed solution was astounding. He meant less to reform legal education than to transform the legal profession. Like Jeremiah, he did not quail before the magnitude of his task.

Though Reed found recruiting difficult, he did not stop beating the drum. He believed the moment was ripe for as revolutionary a change as he suggested. After all, Reed had been hired because in 1913 the ABA's Committee on Legal Education and Admission to the Bar had approached Pritchett for just such a study as Flexner had provided for the AMA. The five able, younger lawyers composing that committee were the stalwarts for the revitalization of the ABA; four of them were academic lawyers. ${ }^{9}$ Unfortunately for the Carnegie reformers, Reed was all too thorough, too concerned with historical foundations, too committed to having all the data in hand, too much the model of German scienticism. The ABA reformers were not ready to tarry for his massive manifesto. By the time it was published, Reed's potential troops, including the committee that had issued the invitation to Pritchett, had enlisted under a less shrill and more professional 
marshall, Pomeroy's old student, Elihu Root. Indeed, the committee, following the strategy suggested by one of its members, William Draper Lewis, dean of the University of Pennsylvania Law School, conspired to offer the aged, illustrious Root his baton. In 1920, the ABA created a special committee to be appointed by and to be under the chairmanship of Root to recommend ways of assuring better candidates for admission to the bar. Root wisely appointed all nonacademic lawyers to it, excepting only Lewis. While the committee had available the draft of Reed's manifesto, it went ahead with its recommendations to the $\mathrm{ABA}$ without waiting for the book's publication. Moreover, it categorically and chillingly rejected Reed's prime and revolutionary proposal, the "differentiated" profession:

With this position we do not agree. In spite of the diversity of human relations with respect to which the work of lawyers is done, the intellectual requisites are substantiaiiy the same. ${ }^{10}$

The Root Committee's reasoning was sound but superfluous; hardly a voice was raised in support of Reed's notion, which was universally condemned as elitist.

What satisfaction Reed found in the committee's report was limited wholly to the considerable-but hardly revolutionary-recommendations for improved education in law schools adopted by the ABA in August 1921. The report deserves our attention. To this day, the standards of our law schools remain founded on it, and any developments, innovations, and improvements of those standards have been merely in degree. The ABA declared that it was "of the opinion that every candidate for admission to the bar shall give evidence of graduation from a law school..." that met four requirements: 1. admission only upon two or more years of college, 2. a three-year curriculum for full-time students or a proportionally longer course equivalent in number of working hours for part-time students, 3. an "adequate library" for student use, 4. a "sufficient 
number" of full-time teachers. ${ }^{11}$ The ABA urged the abolition of the privilege of direct admission to the bar upon graduation from a law school and urged the examination of every candidate by "public authority" to determine fitness for admission. The ABA's recentlyestablished Council on Legal Education and Admissions to the Bar was directed to publish, from time-to-time, a list of law schools complying with the four-point criteria, and to make it available to prospective law students. The president of the ABA and the council were to cooperate with state and local bar associations to urge the states to adopt the requirements specified for admission to the bar. Finally, the council was charged to summon a national conference on legal education, with delegates from state and local bar associations, to attempt to unite the various bodies in support of the adoption of the requirements. The conference, held in 1922, adopted the ABA's standards with only a slight weakening of the admissions requirement by accepting work equivalent to two years of college. In the event, it was a long time before the states accepted the ABA standards in toto. The quality of legal education was not dramatically improved in the wake of the ABA's reform.

Reed took hard the rejection of his notion of a "differentiated" profession. It was bad enough that the ABA, which after all was dominated by practitioners and could be expected to be hidebound, "contemptuously dismissed" the idea; ${ }^{12}$ but Reed had hoped for something better from the academic lawyers' own organization. The Association of American Law Schools had been in advance of the profession as a whole in its concern with legal education. Founded in 1900, it had grown in influence and purposefulness. Though closely linked to the ABA, the AALS was autonomous and, until the second decade of the century, much more active than the professional association. But the academic lawyers did not take any better to Reed's revolutionary suggestion than did the practitioners. In 
1921, the AALS president, Prof. Arthur L. Corbin of Yale, damned the notion of differentiation in his address. ${ }^{13}$ In 1923, almost as if to add insult to injury, the AALS accepted evening schools for membership, a radical departure from the growing exclusivity of the Association that had led to Hastings' expulsion a few years before for inadequate library resources. The AALS, feeling compelled to make common cause with the ABA in the matter of educational standards, accepted the minimalist criteria of the professional association, albeit without much enthusiasm and not for very long.

Reed found himself isolated, a prophet with diminished honor everywhere, a general without a host. He continued the struggle for higher standards in the annual review of legal education until 1935, when it came under the auspices of the ABA and the editorship of a Boalt graduate, Will Shafroth, who was much more temperate than Reed. The annual review provided much usefúl information. It was also a dreary reminder year after year of how little progress was being made towards large scale reform. Still, Reed did not discourage easily; his righteousness remained undiminished. He had one more bolt to hurl, in the form of the study of the contemporary state of law schools, the follow up promised in the volume on historical background published in 1921.

Reed's Carnegie Bulletin no. 21, Present-Day Law Schools in the United States and Canada (1928), implicitly castigated the profession for approaching the "educational and professional problem" of weak legal education "in a spirit of making difficulties" rather than of "scientific enquiry." ${ }^{4}$ It was no call to reform the profession-only the law schools. Reed pinned his hopes on the university law school, both as showing the way to sound education and also as a behemoth that might roll over, crush, and extirpate bad law schools. The 1928 study is not so easily tolerant as the 1921 study had been of the school of part-time teachers and full-time students outside a university context, or of the 
school of part-time teachers and part-time students. Reed was especially critical of the five law schools (out of 111 university-connected schools) which, "although bound to the university connection, possess, either through legislation or by contract, powers or privileges of which they cannot without their own consent be deprived." 15 These anomalous institutions were, of course, in a position to withstand the healthy ministrations of saving grace that the nominally-related university might confer. Cincinnati Law School, Albany Law School, St. Lawrence University (New York), and the law faculty of the University of Denver might well have been considered to have the seeds of redemption in them; at least Reed described them always without censoriousness and occasionally with praise. But Hastings College of the Law seemed beyond salvation, like Jeremiah's kingdom of Judah:

The sin of Judah is written with a pen of iron, and with the point of a diamond: it is graven upon the table of their heart, and upon the horns of your altars; whilst their children remember their altars and their groves by the green trees upon the high hills. [Jeremiah 17:1-2]

Reed's description of Hastings, longer than that of any one of the other five schools, was a diatribe. ${ }^{16}$ Hastings was a "highly anomalous institution" with respect to its organization, established by a "carelessly drawn act" which its founder "lived to regret," a college "lacking the usual attributes of a corporation," over which the University of California "was accorded no control, other than that which it might secure from its power to defeat, or at least to refer to the courts, terms of affiliation of which it might disapprove." Despite this and the rejection of affiliation by the Hastings Board, the school has been "consistently announced in the University catalogues as an affiliated college, and University degrees are conferred upon its graduates...." Whether the 1918 constitutional amendment giving full power to the Regents over the University empowered either the Re- 
gents or the legislature to "dispense with the selfperpetuating Hastings Board of Directors, as a permanent feature of the University organization, only the courts can decide." The whole ended with a barely concealed note of disapproval that "another law school (officially known as the "School of Jurisprudence') is maintained on the University grounds in Berkeley."

Reed's intemperate blast was not the work of a day. In 1918 he had done a first draft of the treatment of Hastings, against the 1921 study; this was not published because the 1921 study was restricted to the historical background. This draft was even more inflammatory against Hastings than the final draft for the 1928 study, which was ready by the summer of 1926 . In 1918 Reed had noted pointedly that the College had been dropped from the AALS in 1916 for want of a library. The 1918 draft also described Boalt as a "rival law school (disguised under the title of Department of Jurisprudence)," 17 and this went forward into the draft for the 1928 book. But the 1918 draft contained a long paragraph that was a call to the Regents of the University to take over Hastings, which Reed omitted from the new, final draft. For reasons that are not clear, Reed, during a meeting at Washington, gave Orrin Kip McMurray, the Boalt dean, a copy of the paragraphs on Hastings. The new draft contained the same disparaging reference to Boalt, but McMurray's outrage went further. $\mathrm{He}$ sent copies of the draft to President W.W. Campbell and Vice-Presidents W.M. Hart and Robert Gordon Sproul of the University, suggesting that it be referred to the Regents' attorney, voicing concern that in such an "intricate" matter it "would be unfortunate if anything that Mr. Reed should say might tend to crystallize opinion in an erroneous way." 18 Campbell sent the file to Regent Garret W. McEnerney (a prominent San Francisco attorney), the Regents' attorney also saw the file, and McEnerney recommended that Dean Simmons of Hastings be given the file. McEnerney agreed with Campbell that there seemed to be "animus on the part of the 
writer [Reed]." ${ }^{19}$ McMurray then showed Simmons the Reed draft. McMurray had already written Reed making specific suggestions of items that should be toned down or omitted altogether. He took strong exception to the reference to Boalt as "disguised" etc.; Reed ultimately dropped it. Further, McMurray urged Reed to reconsider the statement that the state would have to return Hastings' endowment to his heirs if the College should cease to exist (the statement did appear in 1928 anyway). McMurray noted that "there has been no discussion, so far as I know, concerning the possibility of the disincorporation of Hastings College, though in recent years there has been an increasing tendency on the part of legal members of our Board of Regents to raise questions concerning the affiliation." ${ }^{20}$ He loyally noted that Sidney M. Ehrman had recently given a large gift to Hastings and intended to provide further support, indicative of the interest of Hastings' trustees in the College. Dean Simmons, having had an opportunity to digest Reed's diatribe, on June 28, 1926 wrote Reed a civil, but direct letter pointing out inaccuracies in the draft (which were, in fact, few) and objecting strenuously to the "general tone of the article. ..." With justice and correctness, Simmons noted:

I do not believe that any fair minded and intelligent person can read this article as it stands without gaining the impression that it casts a serious reflection upon Hastings and to a certain extent upon the University as well and at least suggests that unharmonious relations exist between the Board of Directors of the College and the Board of Regents. ... Again, it seems inappropriate to suggest unsatisfactory relations between the Board of Directors and the Board of Regents when those Boards themselves have been able to function together harmoniously and without friction. ${ }^{21}$

Simmons sent a blind copy of his letter to Campbell; indeed, Simmons apparently held off sending it until Hart and McEnerney had read it and advised Campbell to tell Simmons to mail it. Hart and McEnerney further advised Campbell to raise the matter with President 
Pritchett of the Carnegie Foundation. Their sensitivity was less to the rough treatment of Hastings than to the implicit condemnation of the University for not taking steps to rid itself of the embarrassment of that "highly anomalous institution," its San Francisco "affiliate."

Campbell's wire to Pritchett respectfully requested reconsideration of the Reed draft. Campbell pointed out that many able and successful attorneys had graduated from Hastings, and that it "is an institution with good faculty and administered successfully in behalf of an excellent student body made up largely of men and women working in San Francisco law offices." 22 The allusion to the law-office work of Hastings students gave Pritchett a handle with which to excoriate Hastings in his reply. ${ }^{23}$ The University offered legal education on "different educational levels"-Boalt at a "higher level," and Hastings at a "lower level." Such a "dual standard" did not fit the "conception of University teaching." If Hastings was a good school, then why a second school at Berkeley? If Boalt "represents the university conception of Law education it is difficult to reconcile the maintenance of a school on a lower level with the ideal of intellectual integrity." That Hastings students worked in law offices and that Hastings had able graduates were considerations that might be equally applicable to medicine, engineering, or any other vocational instruction. Pritchett was alarmed that with so many pressing into law, society could not be sure that those admitted were of ability and high character. Experience showed "that on the whole a high intellectual requirement for admission is the safest method for exclusion of the unfit." Finally, Pritchett noted that the Foundation's interest was only to set forth "as accurate a statement of the facts as can be had..." so that "after these facts have been agreed on we may preach a little sermon concerning them." What is not clear a half-century later is why Hastings was singled out to provide the text for the Prophets' sermon. 
Pritchett had California connections: his wife was the daughter of that legendary early California lawyer, Hall McAllister, and the Pritchetts vacationed in Santa Barbara. Campbell and Pritchett were astronomers and both were members of the Bohemian Club. Apparently they met later in the summer of 1926 at the Grove and smoothed their ruffled hackles, talked about interstellar velocities, and enjoyed some common good cheer. But neither Pritchett nor Reed made any substantial concession to Hastings' position, and the passage appeared in the final work in 1928 largely unaltered.

Pritchett's letter demonstrates the mind-set of the Carnegie reformers. No professional education could be "high quality" unless it was in the full context of the university community. Preferably, the professional school should be on the campus of the university; if it was not (and a great many medical schools, especially, were not) then it must be under strict university control. Pritchett also could not conceive of a university with more than one professional school in any one discipline. The Germanists' conception of educational institutions was of the unitary campus, the neatly arranged "faculties" of the traditional European Continental model. Already the University of California had begun to break the symmetry, with its "Southern Branch" at Los Angeles. Campbell, who had been under pressure to start a law school in the Southern Branch and had resisted successfully, was sympathetic to Pritchett's position on this.

Was Hastings offering a legal education at a "lower level" than Boalt? As far as admissions standards were concerned, not at all. Since 1913, both institutions had required two years of college for admission. There was only the small difference that Hastings had a provision for "special students," those already admitted to the bar who wished to receive more formal education; they did not receive the LL.B., and save for the immediate post World War I years of dislocation, they did not comprise 
more than 10 percent of the student body, and usually about 5 percent. Neither Boalt nor Hastings had any other academic requirements for admission: no tests, or other formal assessments. With respect to curriculum, in the 1920s there was little or nothing to choose between the two schools. The first-year curriculum was virtually identical, and the curriculum of the last two years demonstrated no significant variations. The instructional method, the case method, was the same in both. Grading standards at both institutions were markedly similar, and not rigorous enough, but that was a common failing of all law schools at the time. In only three areas was there marked dissimilarity between Hastings and Boalt. One of these was in the lack of adequate physical facilities at Hastings. The three lecture rooms on the ground floor of the California State Building, where Hastings had been since 1923 and was to remain until 1938, were adequate in capacity until the early 1930s, but bad acoustically, ill-proportioned (being too long and cavernous), arranged so that passage to classes was disturbing, poorly ventilated, and too susceptible to interference from street noise. The library (only about 4000 volumes in 1930) was inadequate and at best a supplement to the City law library; worse, it was located in the corridor to the classrooms and doubled as a cloakroom and the assistant registrar's office. Only the dean had an office; other faculty did not. The cafeteria chairs in the classrooms were apparently made in San Quentin and were inferior to the desk-type seating that had become universal and was considered essential (as it still is) to instruction by the case method. The second area in which Hastings and Boalt differed was in the utilization of faculty. Save for the dean, the Hastings faculty was all part time and engaged in practice, though two Hastings professors taught what was substantially a full load at Boalt. At Boalt, where there was a better ratio of faculty to students than at Hastings, the faculty was largely full time. In terms of quality of faculty based on academic background, there was little to 
distinguish between the two. During Harrison's administration, all Hastings faculty, except for James A. Ballentine and two instructors who taught one or two courses in the $1920 \mathrm{~s}$, had a law degree from one of the "best" law schools, including Harvard and Yale. Finally, all Hastings instruction was given in the morning, and it was accepted that the students could be employed in the afternoon. Boalt classes were not limited to the morning, outside employment was not encouraged, but Boalt students were expected to partake of the collegial pleasures of a most pleasant and lively campus. Hastings students were hardly in a position to be enticed by such extracurricular activities. It is a moot point as to which was the better way for young students to pass the hours outside the classroom and study.

Hastings also deserved better at the hands of the Carnegie reformers by virtue of the role it played, through its dean, faculty, and alumni, in the reform of bar admissions standards in California. The California Bar Association, founded in 1909 by such reformminded lawyers as Warren Olney, Jr., had from its inception a Section "I" on Legal Education and Admission to the Bar. The first report of the new section presented to the first annual convention in 1910 proposed legislation requiring every applicant for the bar to have had at least three years of "actual study of the law" and establishing a state board of law examiners. ${ }^{24}$ Nothing came of this proposal at the time, but Section "I," like its ABA counterpart, was heavily academic in membership and thrust, and not to be easily deterred. Orrin Kip McMurray was the moving spirit behind higher admissions standards. In 1918, the CBA accepted the Section's proposed legislation abolishing admission by privilege of graduation from law school and requiring examination of all candidates by a board of bar examiners appointed by the state supreme court. In 1919, the legislature and governor enacted the proposal. The first board of bar examiners, appointed by the supreme court, consisted of three practicing attorneys (teaching 
lawyers were excluded to avoid the appearance of favoritism), two of whom were Hastings alumni. Charles A. Shurtleff, '82, soon to be a justice of the supreme court and a Director of Hastings, 1915-19 and 1921-41, and Warren Gregory, '90, a stalwart of Section "I," served with Max C. Sloss, Harvard LL.B. '93, a former justice of the California Supreme Court. They were all active reformers.

The first bar exams were set in 1920. By the new system, Hastings lost its statutory privilege of having its graduates admitted ex parte. Henceforth, its graduates would compete on equal footing. There was no opposition from anyone connected with Hastings or acting on Hastings' behalf. On the contrary, the newly-appointed dean of Hastings, Maurice E. Harrison, served on Section "I" in 1919-20, and succeeded McMurray as chairman of the Section in 1922-23. In 1921, McMurray had moved that the $\mathrm{CBA}$ take note of the $\mathrm{ABA}$ resolution growing out of the report of the Root Committee. In 1922, the CBA incorporated the ABA resolution in the form of a legislative proposal, with the intention that it should take effect in 1926. This proposal went nowhere in Sacramento, and it fell to Harrison in 1923 to move reaffirmation of the $\mathrm{ABA}$ resolution and to move further that, as a step in that direction, at least "graduation from high school" be required for admission to the bar. ${ }^{25}$ The convention was deeply split, not over reaffirmation of the ABA resolution (its opponents realized that for the time being the new standards were moot), but over the requirement for a high school diploma. In this argument, W.B. Bosley, Yale LL.B. '94, former instructor and latterly a Director of Hastings, pressed for allowing "equivalent work" as an alternative to "graduation." The section had to accept an amendment that would add to "graduation" the words "or the completion of such preliminary education as will be accepted for entrance to the Department of Letters and Science of the State University." Even thus amended, the resolution passed by only one vote-27-26. The Abe 
Lincoln Myth was not yet dead. At least Dean Harrison was on the side of the angels-and of better educational standards for candidates for the bar.

The ramifications of Reed's blast out of Zion were considerable. Strangely, the Hastings Board of Directors took no official notice of the blast. Slack was certainly fully informed by Simmons before Simmons replied to Reed, but Slack's reaction is unknown. The University administration, particularly President William Wallace Campbell, was not prepared to put up much of a fight once the draft had been toned down so as not to reflect disparagingly upon the University and its Berkeley constituents. Boalt's Dean McMurray had done his best for alma mater, but he was not in the strongest position from which to launch a counterattack. The Reed attack came at an unfortunate moment. In 1922, the Hastings Board had made an overture to the University for the granting of the A.B. to Berkeley students who transferred to Hastings after their third year and completed the first year of law school there. A Berkeley undergraduate who did the same with respect to Boalt would be granted the A.B. There was no academic reason against it; the first-year work at both law schools was identical. The proposal knocked around the corridors of Berkeley for over a year. Campbell finally vetoed it, fearful that any closer tie between the University and Hastings would be taken as encouragement of "duplication" of programs within the University structure: "There would probably be the encouragement to legal interests in other parts of the State to hope for even a third Department of Law within the University." ${ }^{26}$ The Reed attack went some way towards confirming Campbell's instinctive reluctance to have much to do with Hastings. In his principal lieutenant, Vice-President Robert Gordon Sproul, the sentiment induced by Reed was that of a deep suspicion that Hastings was not up to the University's standards of scholarship. In 1930, Sproul became president of the University of California, to serve for 28 years, the 
longest tenure in its history, and to become the single most powerful figure in its history. As president of the University, he would prove to be no friend of Hastings.

Beyond the playingfield of university politics, Reed's attack contributed to Hastings' exclusion from the Association of American Law Schools in 1927. Having lost its membership in the AALS in 1916 and regained it in 1920, the College was in a weakened condition vis-à-vis its sister institutions in the professional association of law schools. Reed's criticisms of legal education as a whole had made the AALS more sensitive to standards and it had moved the association to higher standards for its members in the mid-1920s. Though Reed's final trumpet was not publicly blown until 1928, the contents of Carnegie Bulletin no. 21 were well known a year before publication. Reed's particularly scathing criticism of Hastings made the College exceptionally vulnerable to peer pressure and subject to rather closer scrutiny than would have been the case otherwise. In the summer of 1927, Professor Richard R. B. Powell of Columbia was dispatched to San Francisco to make an official inspection of Hastings on behalf of the AALS executive committee. He found that it had admitted students without the requisite prior two years of college work from an accredited college (though its admissions requirements called for this standard), that it did not have three full-time instructors as the new AALS criteria required, and that it did not keep adequate records of student performance. ${ }^{27}$ Of these findings, the latter two were incontrovertible; the first turned on what constituted an accredited undergraduate college, and the College was not much of a sinner. At the AALS annual meeting in December 1927, Hastings was dropped from the association. It would be two decades before it again enjoyed the company of its sister law schools in academic association.

While Hastings might brave its loss of membership in the institutional association, Reed's polemic tarnished its reputation at large just as the College was feeling the 
full force of competitors in California legal education. It required more skepticism than most academics, practitioners, and prospective law students possessed to put Reed in perspective, to ask the question: How correct was Reed's singleminded-perhaps simplemindedproposition that only one kind of university-level legal education was valid and satisfactory?

Hastings had no California competition in formal legal education for the first two decades of its existence. Its most strenuous competitor then was the University of Michigan, and it lost a few of its potential students to other Midwestern law schools and the major Eastern schools. With the turn of the century, out-of-state schools beckoned fewer Californians. The reason was the rapid, almost sudden appearance of three new schools in California. Between 1898 and 1901, Hastings' three great rivals, Boalt, and the law schools at USC and Stanford, came into being. The Law School Association of Los Angeles, formed in 1896, had been incorporated as the Los Angeles Law School in 1898. In 1901 it affiliated with a Methodist college, the University of Southern California, that was from the outset ambitious and expansionist, even aspiring to be the southern surrogate of the northern-based state university. ${ }^{28}$ In 1904 the law school was integrated with USC. Leland M. Stanford Jr. University was the foundation of a single donor in 1885 . It rapidly developed a law program which became a fully developed degree program in 1899. Stanford, well-situated on the peninsula below San Francisco, rapidly acquired a devoted clientele and a reputation for academic excellence. The developed degree program at Berkeley began in 1901. Boalt, Stanford, and USC, all full-time day schools, like Hastings, constituted Hastings' peers in the California spectrum of legal education before 1940. Until the later 1920s, USC's standards and program left a great deal to be desired. Located in downtown Los Angeles, the USC law school had low admissions standards, a poor 
faculty-student ratio, a program which at best provided the essentials, and a strident student recruitment policy. ${ }^{29}$ But increasingly, its graduates were filling the judiciary of the rapidly expanding California southland, and it was already establishing a persistent reputation for being the law school to attend for those aspiring to practice south of the Tehachapis.

Below the august level of Boalt, Stanford, and USC, Hastings was being challenged by a plethora of new law schools. By the end of the 1920s, Hastings was literally surrounded by competitors in its own metropolitan bailiwick. San Francisco Law School was in business in 1907, Oakland College of Law secured a charter in 1912 (later it would absorb the St. Mary's College law program), in 1910 the YMCA Law School began to offer degrees (it became Golden Gate), and two Jesuit colleges, Santa Clara and St. Ignatius (afterwards the University of San Francisco), were in full operation in 1910 and 1912, respectively. San Francisco Law School and Oakland College of Law were strictly proprietary schools-six of the seven stockholders of the latter were its instructors in the early 1930s-and both were evening schools. San Francisco Law School was almost a stepdaughter of Hastings; its first dean was James A. Ballentine, one of its earliest and longest-tenured teachers was Robert W. Harrison, its second dean was Robert L. McWilliams, and David E. Snodgrass began his teaching career there in 1925 as a part-time instructor. YMCA-Golden Gate was a nonprofit evening school. The two Jesuit institutions were, of course, nonprofit and church-related, and both were evening schools only until about 1930. In 1919, an enterprising former salesman for the La Salle correspondence law course founded Lincoln University College of Law in downtown San Francisco, secured its incorporation in 1926, started a Los Angeles branch, and operating it primarily as an evening school turned a roaring profit with more than 500 students in 1927. Somewhat further afield, in 1927 a nonprofit evening school was founded 
in Sacramento by a local lawyer named Verne A. McGeorge. Even Fresno boasted a law school of sorts, a profit-making, hand-to-mouth operation that failed after a few years because it did not make enough profit for its entrepreneur. The same phenomenon of proliferation was apparent in the southern part of the state where, by the end of the 1920s, a number of evening schools had come into existence, most of them centered in Los Angeles, but some along the southern littoral to San Diego. USC felt the competition of these schools most keenly.

Of all these lesser competitors two things can be said insofar as Hastings was affected: they were all urban-centered, and they tended to draw students from the same milieu as Hastings. While there was some variation in standards (the two Jesuit colleges were credited with good standards of instruction and testing), all of these schools were markedly inferior to Hastings in admissions requirements and program. They challenged Hastings for the part-time student in the urban environment, but the competitive sting was somewhat ameliorated by their clientele being strictly evening students. The evening schools had a bad reputation with all academics, the leaders of the bar, and many of the general public. The worst of them deserved it; the best of them should have been accorded a bit more tolerance because they did offer an honest path to the bar. All of these schools posed a problem for Hastings that went beyond mere competition for students. Despite the evident superiority of Hastings in every way, that most Hastings students worked in the afternoons tended to blur the distinction between Hastings and the evening schools. The uninformed-even those who were informed, but only by Alfred Zantzinger Reed-were easily persuaded that Hastings was closer to the evening schools than it was to Stanford and Boalt with respect to standards and program.

How serious was the competition for students mounted against Hastings by all of its challengers? 
Ranged against Boalt and Stanford, competition appears to have cost Hastings something in the formal, paper qualifications of its entrants. Increasingly in the 1920 s, during the second great "boom" period of American higher education, it was the aspiration of every professional school to become a wholly graduate institution. The Carnegie reformers found substantial agreement among academics with this dearly held proposition of theirs. The assumption was that a full four-year college course produced a student better able to undertake professional study than one who had had only two or three years of college. Between 1913 and 1927, Hastings, Boalt, and Stanford required only "junior standing" (two years of college) for law work. In fact, in 1925-26, of Stanford's 314 law students, 115 (37 percent) had a bachelor's degree. In 1926-27, of Boalt's 195 students, 181 (93 percent) had a first degree, a remarkably high percentage, made more impressive by the fact that none of the 14 without the degree were merely of junior standing when admitted. In the last year for which we have complete degree data for Hastings in this period (1924-25), of 112 students, 21 (only 19 percent) had a first degree. Until well into the first decade of the century, the entering class at Hastings had between 30 and 45 percent bachelors, save for the first five entering classes, when the proportion was about 20 percent. The peak of degree entrants until after World War II was during the years of Slack's administration (40-45 percent), a direct result of his emphasis on high admissions standards. Considering how little emphasis was then placed on a first degree preparatory to entering professional study, this was a remarkable showing for Hastings during the first three decades of its existence. Beginning in the second decade of this century, the percentage of degree entrants at Hastings declined from about 25 percent to 15 percent in the late 1920s. Clearly, those with the money and the time to complete an undergraduate education (even at the relatively inexpensive state university) were under less pressure to find a job 
while attending law school, and preferred to remain in the campus community amidst the pleasurable charms and engrossing extracurricular activities of Berkeley or the Farm in Palo Alto. The son of a Sicilian immigrant shoemaker found three years as an undergraduate at Berkeley expensive, even though he lived at home in San Francisco, whereas enrollment at Hastings afforded him a chance to get to the bar by the most direct route, and with a sound legal training, during which he could also work to support himself. This Hastings graduate's subsequent career at the bar and on the bench should serve to put in perspective how little the formal, paper qualification of the first degree counted in practice. The decline of degree entrants at Hastings was undoubtedly caused by Boalt's and Stanford's attraction of students with the bachelor's degree. But the decline had little ultimate significance with respect either to the true quality of Hastings entrants or to the professional competency and career potential of its graduates. This would remain the case long after Stanford and Boalt became entirely graduate institutions, requiring the bachelor's degree for admission, about 1930 .

The real impact of the challengers' competition came in the matter of numbers. The graph below tells the tale. It displays the average size of a graduating class at Hastings by five-year periods, from 1881 to the end of Simmons' administration in 1940. The darkened bases indicate graduates with a first degree, save for the years 1906-10, for which the data are insufficient. The early peak periods were 1881-85 and 1896-1900. The lows between them represented the fewer graduates that resulted from Slack's tough admissions broom sweeping fine. Beginning with the turn of the century and rising competition from new law schools in California (especially from the lesser schools, which were generally inferior to Hastings), there was a steady decline of graduates broken only by a modest upturn in 1911-15. The deep trough in 1916-20 was occasioned largely by the impact of the First World War. The post- 


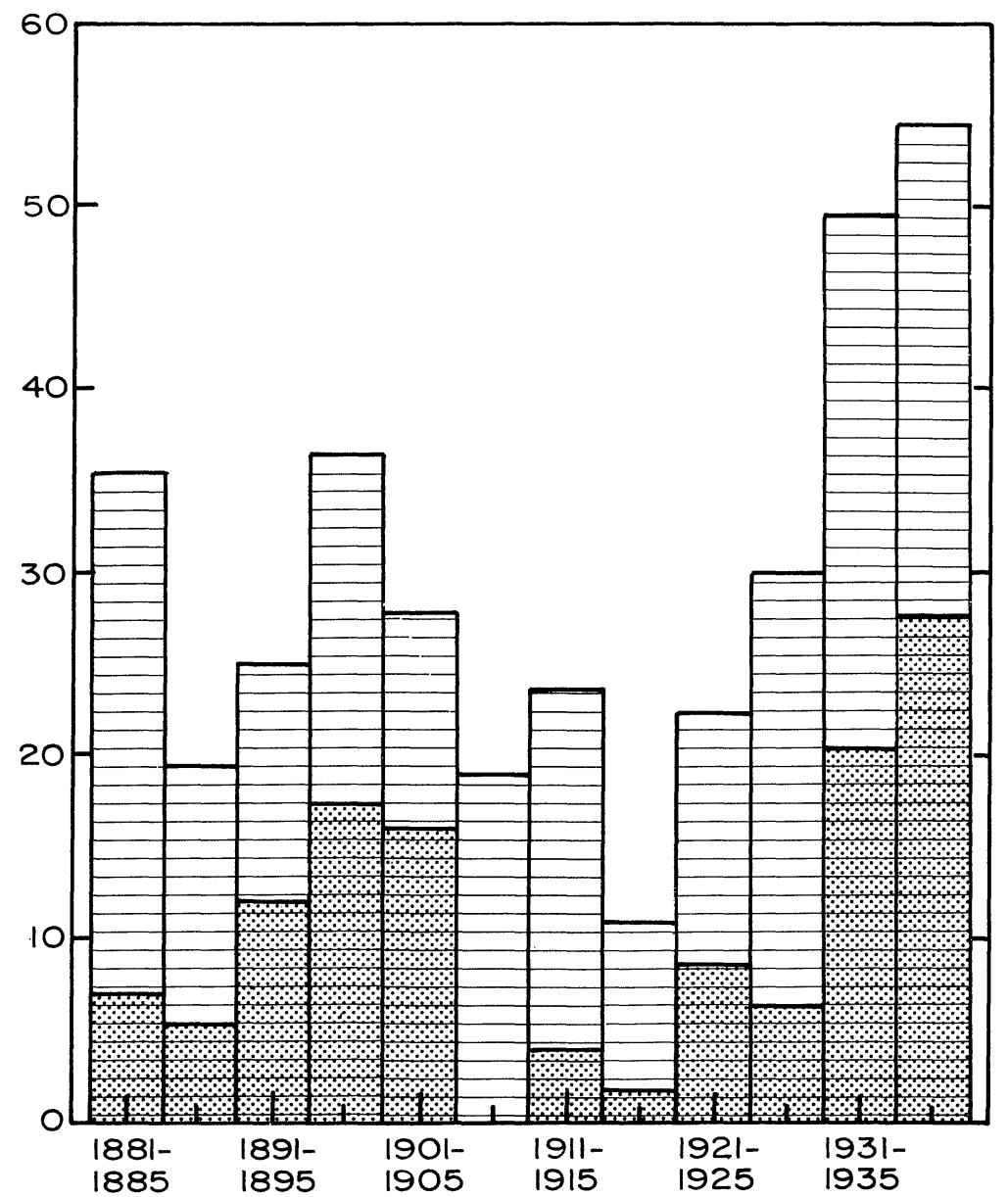

Graph 2. Average Size of Graduating Class and of Graduates with a First Degree, 1881-1940

war educational boom worked a reversal of the trend, but the 1921-25 pickup was really slight, and the 192630 increase brought a graduating class back only to about the level of the first decade of the century. The significance of the great jump in the 1930s is discussed more fully below.

Another way of looking at the competition posed by the new law schools, including Hastings' peers (Boalt, Stanford, and USC), as well as the lesser schools, is to 
note the geographic origins of Hastings recruits. At the outset, around half of the College's entrants came from San Francisco, 80 percent from San Francisco and the Bay Area as a whole. There was not much fluctuation in this proportion of City and Bay Area entrants to entrants from other parts of the state (out-of-state entrants were negligible) until about 1910 , when there was a sharp upswing (from 15 to 30 percent) in students from other parts of California, excluding southern California. In 1915-19, the proportions returned to the earlier levels and remained there until 1930. USC's challenge to Hastings was already being felt in the much reduced number of students coming to Hastings from southern California; by 1915, Hastings' draw of southern Californians had become negligible, down from about 10 percent of entrants in its early years to about 3 percent. In the early period, the high percentage of City and Bay Area entrants was accounted for by the relatively high proportion of the population of the state in that region. Reasonably, it could have been expected that as the population of California increased, not only south of the Tehachapis, but also in the Central Valley, the mix at Hastings would begin to reflect a wider geographical base of recruitment. However, what USC did in the south, Boalt and Stanford accomplished on a broader plane in the north. Hastings became increasingly confined to being a northern-metropolitan law school, confirming the tendency for the College to find its students among those who lived and had to work in close proximity to the City while attending law school. Consequently, the rapid proliferation of City and Bay Area evening schools, drawing from roughly the same pool of potential students as Hastings, sharpened the competition.

Competition for students was not merely a matter of prestige. The student registration fee was the only elastic source of revenue that Hastings enjoyed. During the 1920s the numbers of students did not rise rapidly enough to provide the increased funds requisite for 
maintaining the program. Only by increasing fees, which threatened the College's economic competitiveness with its evening-school challengers, could revenue be increased. The general round of faculty salary increases in 1925 was provided for by increasing the registration fee from $\$ 50$ to $\$ 75$ a year. The 20 percent salary increase of 1928 required the fee to be increased to $\$ 100$ a year, a sizable jump. In 1936 , the addition of another full-time professorship was funded by increasing the fee to $\$ 110$ a year. Thanks to the sudden jump in Hastings enrollments in the early 1930s, the 17 percent faculty salary increase of 1933 required no increase in the registration fee.

The impact of the Great Depression on the six major California law schools in terms of enrollments is vividly displayed in the graph below, which plots fall semester enrollments for the years 1928 to 1937. Only two institutions evidenced increased enrollments in the early 1930s: Hastings and Boalt. The reason is not difficult to determine; these two state institutions were much gentler on the student's pocketbook than virtually any other law school in California. In 1928 Hastings, Boalt, and Golden Gate had a \$100 annual fee. Over the period, Hastings and Boalt increased their annual fees to $\$ 110$ and $\$ 106$ respectively; the fees for the other law schools went up sharply (only Balboa Law College, San Diego, an unincorporated evening school loosely affiliated with the school system of the city, and with an enrollment that hovered around 50, never went above $\$ 100$ ). Stanford's fee was $\$ 285$ in 1928 ; in 1937 , it was $\$ 360$. USC's fee in 1928 was $\$ 249$, and in 1937 was $\$ 300$. The fees of the three Jesuit schools, St. Ignatius (University of San Francisco), Santa Clara, and Loyola in Los Angeles, began at the $\$ 100-\$ 200$ level in 1928, and by 1937 had risen to a range of from $\$ 186$ to $\$ 280$. To the low fees at Hastings and Boalt was added the advantage of getting a degree from a "better" school in hard times, there being no point in getting a degree from an inferior institution, especially if it cost more. 


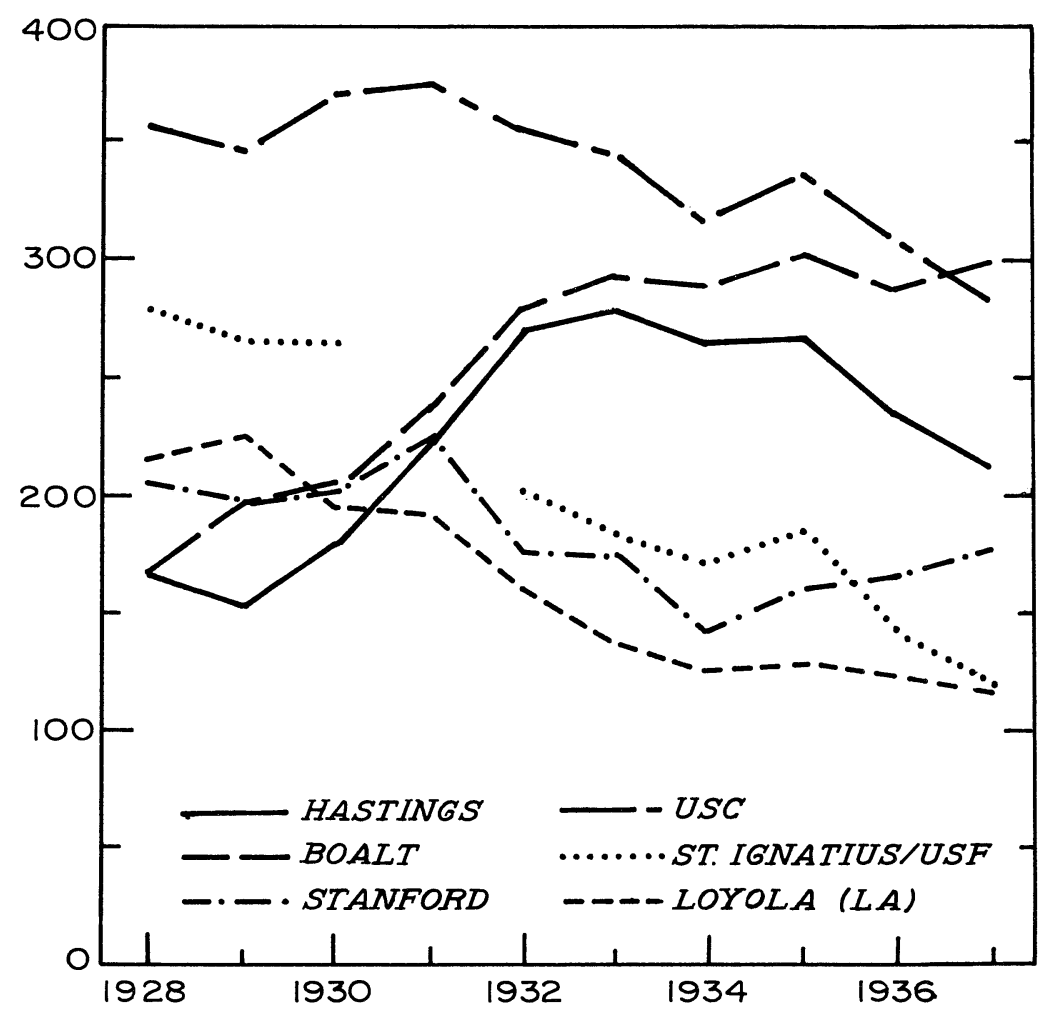

Graph 3. Fall Enrollments,

Six California Law Schools, 1928-1937

Boalt's growth was the most phenomenal and the most steady: by 1937 it was at 179 percent of its 1928 enrollment. Hastings did well, with a net increase by 1937 to 127 percent; though the later 1930s witnessed a steady decline, probably accelerated by Hastings' not yet having achieved accreditation, and by its limited enrollment, beginning in 1933-34. Stanford, of the private schools, did best. It entered a situation of financial "steady state" in the early 1930s, but its enrollments did not plummet, and its net loss over the period was only 14 percent. Stanford's alumni were loyal and possibly less severely wounded by the Depression than were humbler folk. As the Depression lightened somewhat in 
mid-decade, the old Stanford clientele began to come back, and a new clientele that was prepared to put its money on prestige also emerged. USC was harder hit. Its net loss between 1928 and 1937 was 21 percent. However, it still enjoyed its regional preeminence, and if its clientele was less moneyed than Stanford's, it was no less loyal. The three Catholic schools were in dire straits. The graph shows how beset were USF and Loyola, and Santa Clara, always a small school, was in danger of failing entirely. Only the devotion of the Society of Jesus and the Church's generous and committed laity managed to keep open these schools which were monuments both to the educational ideals of late nineteenth century American Catholicism and the aspirations of immigrants, especially those from Ireland and Italy, to have their children enter the mainstream of American professionalism and play the political role commensurate with their numbers. The schools which exhibited the highest mortality rate were the part-time schools, especially the proprietary schools run for profit. All of the San Francisco Bay Area part-time schools (proprietary and nonprofit) survived, albeit with much reduced enrollments. McGeorge in Sacramento managed very creditably with a 7 percent net loss in enrollments. The Los Angeles Area schools were shattered. Of the nine law schools founded there between 1924 and 1932, four did not make it through the Depression, and their lives were in fact very short indeed. The five that survived suffered enrollment losses that reduced them to shadows of their former size.

Financially, the Great Depression brought no real hardship to Hastings. The increased fees coupled with the increased numbers of students in the early 1930s gave the College a taste of prosperity such as it had not enjoyed before. The College's library was a major beneficiary; Slack, who as vice-president headed the Board and as chairman of the finance committee had the major say in College economics, saw to that. The library's growth was modest, but it was significant, espe- 
cially in building up the reports. The 1933 faculty salary increase made Hastings' salaries about 20 percent higher than the average of University of California salaries for the lower ranks, and only slightly lower in the case of the three professors (R.W. Harrison, J.A. Ballentine, and Perry Evans), adjunct to Dean Simmons, whose salary of $\$ 8400$ was higher than that of Dean McMurray at Boalt. Indeed, since the average of UC salaries eroded for the professorial rank and remained almost steady for the lower ranks from 1933 until post World War II, Hastings' salaries, which were not lowered in the 1930s, were better than competitive. It is hard to say how well the College did with its endowments, particularly the Hellman chair funds, but the finance committee was actively selling and buying stocks in the early 1930s. In academic 1932-33, a six-week summer session of two courses was instituted, bringing in $\$ 35$ per course per student. The summer school continued throughout the decade, giving to the faculty who taught in it $\$ 600$ extra and a nice surplus to the College's general funds. The College was not in the lap of luxury, but it did not suffer want.

The greatest problem faced by the College was the inadequacy of its physical plant to deal with increased enrollments. In academic 1933-34 Hastings for the first time in its history limited enrollment; it continued to do so until the end of the decade. This eased the problem somewhat. Though the choice of students was made on the basis of academic record at the undergraduate level, there were some complaints from unsuccessful candidates and some instances of pressure placed on the dean to admit favored students. ${ }^{30} \mathrm{~A}$ fourth, smaller classroom was secured in the State Building, but the overcrowding remained severe, and a search was begun in earnest to find new quarters. The search reached fruition in Simmons' last years, raising the acute problem of securing a larger state appropriation for the larger, commercially let new quarters. The state had already expanded its largesse to Hastings to cover the additional 
space in the State Building and to provide additional equipment. With biennium $1933-34$, the $\$ 9400$ per annum appropriation which had obtained since 191112 was increased to $\$ 14,200$, in 1935 -36 to $\$ 15,312$, where it remained until biennium 1939-40, when it was raised to $\$ 20,661$ per annum, principally to cover the higher rent and new equipment needed for the new and somewhat larger quarters which the College occupied in May 1938 in the California Building at 515 Van Ness Avenue. ${ }^{31}$ The University had been approached by the state to make up the required sum, but disclaimed all responsibility for housing its "affiliate," making the additional legislative appropriation necessary.

Hastings' relatively benign financial condition during the Great Depression was too modest to stimulate curriculum change or faculty expansion, to expand significantly the College's instructional program. At the outset of Simmons' tenure, 38 hours of instruction per week was offered; by the end, this had risen to 47 hours. The first year was largely unchanged: rather less emphasis on Real Property at the end of the period than at the beginning, which redounded to Contracts ( 6 semester-hours increased to 7); Equity was reduced from 2 semester-hours to 1, and Agency correspondingly increased from 2 semester-hours to 3. A course in Legal Ethics (1 semester-hour) was introduced in the 1930s, less from any outside stimulus, such as has led to reemphasis on the subject in the last few years, than from a commendable desire to introduce fledgling attorneys to the subject. At this distance, it is impossible to say whether or not it was any better taught or any more effectual in its aim to heighten the moral sensitivities of lawyers than are our efforts today. Between 1925 and 1940, the second-year curriculum was altered, largely by rearrangement with the third-year curriculum. The core of the second year remained Sales of Private Property, Negotiable Instruments, Private Corporations, Wills-Titles-Administration, and Equity (jurisdictions). But by 1940, Trusts had been shifted to third year, 
Mortgages combined with the third-year Suretyship, and Public Service Corporations dropped. Constitutional Law was moved from third year to second, and a course in Legal Bibliography (1 semester-hour) was added. The third-year curriculum remained centered on Conflict of Laws, Evidence, Code Pleading (and Practice), Suretyship (and Mortgages). Robert W. Harrison's peripheral course on California Government was dropped when his load was reduced in 1936-37 to accommodate a second full-time professor. Admiralty was given as an elective throughout the period, and new electives in Taxation, Bankruptcy, Accounting, and Administrative Law were added. The increased number of instructional hours (9) were the modest consequence of the additional third-year electives.

The most notable curriculum advance was the creation of a Legal Aid Clinic course in 1931-32, taught by Alex Sherriffs, '23, a first semester ten-week course comprising a weekly two-hour seminar and a half-day in the office of the San Francisco Legal Aid Society. The chief proponent of clinical training was John S. Bradway, who had moved from private practice in Philadelphia (where he had sparked the successful Legal Aid Society of Philadelphia) into academia via political science at Haverford and two years at USC's Law School before joining the law faculty at Duke in 1931. Bradway was a prolific writer on clinical work, active in the ABA and the AALS in promotion of the program that he believed would supply the practical dimension of legal education that was lost when lawoffice training gave over to the law school. ${ }^{32}$ Hastings was an early convert to Bradway's crusade, and Sherriffs' thoughtful, well-structured, and academically sound clinical seminar was a major addition to a law school whose avowed purpose was "to offer systematic and thorough instruction in those branches of jurisprudence which will prepare the student for the practice of the profession of the law." 33

Over all, however, Hastings' curriculum in the 
Simmons years was not so imaginative as the clinical seminar, and the College fell behind its peer competitors in the number and range of electives available to third-year students. For all of its practical emphasis, Hastings should have made at least a faint obeisance to the philosophy of law, legal history, international law, and comparative law. And the failure to offer courses of a most practical nature, such as Domestic Relations (tried, but soon dropped at Hastings), Insurance, Government Regulation, and Industrial Law was a serious defect in its curriculum; it was unduly restrictive of the training its students ought to have received in the age of the New Deal if they were to hold their own against Boalt and Stanford graduates in practice at the bar.

The faculty continued to be a good one, though some of its stars of former years were not replaced by men of equal capacity. Robert W. Harrison remained a steady performer, but he was spread too thin among the attorney general's office, San Francisco Law School, and Hastings, and he was aging. The loss of Golden W. Bell to government service in 1930 was a sore blow. His course in Admiralty was in due course restarted. His course in Contracts fell to David E. Snodgrass. Snodgrass had the reputation of being one of the best teachers at Hastings-quick, always prepared, maintaining a rigorous standard, and manifesting a flair for teaching Contracts that is rare at any time, anywhere. William H. Bryan (Equity and Trusts) was learned, but always had trouble getting the best work out of his students, tended to lecture too much, and so failed to attain the full potential of the case method in his courses. James A. Ballentine became increasingly cranky and appears to have slipped as a teacher; in 1935-36, he had, to be relieved of Constitutional Law, though in his defense it must be stressed that Criminal Law and Torts were his specialty. Two former San Francisco superior court judges, Marcel E. Cerf, '00, and Adolphus E. Graupner, '97, gave good service teaching Code Pleading and Practice and Taxation, respectively. Dean Sim- 
mons, whose specialities were Property and Conflicts, and (under duress) Constitutional Law, and David Snodgrass were the best that Hastings had in the classroom. The College could have used more teachers of that caliber. Because its faculty was almost entirely part time, Hastings did not have to keep pace with the academic labor market as did the peer schools manned by full-time, wholly academic, teachers. At the same time, it could not recruit from a national talent pool, having to find its teachers from the profession in San Francisco. During the Depression, the College's monetary incentives suffered in proportion to what the ablest lawyers could still make in practice, and consequently the faculty became increasingly composed of younger lawyers with small practices and older lawyers, such as Cerf and Graupner, who could afford semi-retirement. During the same period, the peer schools were in an even stronger position to recruit and retain eminent academic lawyers because such nonpracticing teachers had no alternative employment. In the matter of quality of faculty, as in the case of curriculum and program, Hastings began to slip behind its peer competitors.

It was the Board of Directors' growing appreciation of how rapidly the College was falling behind its peer institutions that moved Hastings out of its somewhat self-satisfied reverie and into a more competitive stance. The Board had taken with apparent equanimity Alfred Z. Reed's jeremiad; it took no official notice of the College's expulsion from the AALS in 1927. An astute, knowledgeable, and friendly outsider observed in the mid-1930s that the Directors had long been more concerned with substance than with form, that so long as the work done by Hastings was of good quality, they were not particularly interested in outside opinion of the College. ${ }^{34}$ Such indifference to image was commendable, provided it did not constitute a myopic disregard for changing-mounting-standards of legal education. In fact, the Board's studied indifference was fast becoming untenable. It might well have been enjoy- 
ing the boom of so many students that it had to exclude applicants, feeling the warmth of greater revenues from students and state, but the Board could no longer ignore Hastings' loss of preeminence in California legal education, and the speed with which it was being outdistanced by its younger rivals. By the mid-1930s, Hastings was sensitive to the need for change. Another clarion call from without the walls moved the College to a positive response.

This time, the outside stimulus was more muted than Reed had been, and it represented not a private foundation, not even the academic association, but the practitioner's professional body, the American Bar Association. Since the Root Committee's report, the ABA had moved into the business of accrediting law schools. In 1933, of 199 law schools only 85 were approved by the ABA as meeting the rather minimal standards of two years of college for admission, a three-year program (for full-time schools), a library of 7500 "usable volumes," at least three full-time teachers, a teacher to student ratio of 1 to 100 , adequate facilities, and operation on a non-commercial basis. There were six full-time institutions connected with a university or college which came very close to meeting these requirements. Hastings was the largest, and the most eminent, of these six. In the August 1934 issue of the American Bar Association Journal, the secretary to the Section of Legal Education of the ABA, Alexander B. Andrews, called attention to the problem of law school standards, and pointed out that it "would appear that immediate further improvement of the [law] schools is most likely to be found ..." among such schools as approached so closely the ABA approved schools. ${ }^{35}$ In January 1935, Andrews wrote Chief Justice William H. Waste, '94, and the rest of the Hastings Board, with copies to Dean Simmons and President Robert Gordon Sproul of the University, calling their attention to Hastings' status and also noting that the regional accrediting association of universities and colleges required that the professional schools of a uni- 
versity be accredited by the relevant professional organization-the ABA in the case of law schools. ${ }^{36}$ Implicit was the threat (not very present and clear) of disaccreditation of the University because Hastings was not approved by the ABA. However, the University took the matter seriously, and Vice-President Monroe E. Deutsch (who was a good deal better disposed towards Hastings than Sproul was) conferred with Simmons about the matter. Simmons, understandably, was cautious, pointing out the problems of expense, the difficulties of getting two additional full-time faculty-the only step that would be required for ABA accreditation-of sufficient experience and standing, the delicate matter of having to let go part-time teachers of proven worth and long devotion in order to hire the full-timers, and the fact that Hastings had a "special obligation to turn out men for the actual practice of the law, not for teaching or research in it."37 But Simmons did admit that the success of Hastings graduates on the bar examinations had not in general been as high as that of Boalt graduates. This was the key to Simmons' willingness to broach the whole matter to the Board. In February, a special committee of the Board (Directors Ehrman, Bosley, and Olney) was appointed to confer with Simmons about the "desirability of the appointment of one or two additional full-time instructors. ..."38 The committee's report to the April meeting was deferred to a future meeting. Again in July action was deferred-but Simmons was authorized to attend the ABA Convention in Los Angeles the following month. Finally, in February 1936, the Board took the first step towards accreditation. Effective July 1, 1936, Assistant Professor David E. Snodgrass was to become a full-time instructor ( 8 hours per week) with the rank of professor. Professor Robert W. Harrison was to be reduced in load and salary to effect the conversion, and the student registration fee was raised from $\$ 100$ to $\$ 110$ per annum to cover the increased salary commitment. Simmons reported to Deutsch, with considerable 
satisfaction, that Hastings was now two down and one to go, and that the third full-timer would be added probably in the "near future." 39

It was a long time before the other shoe dropped. The Board backed off from further action. The conversion had not gone down well with Harrison; moreover, an old grad and part-time instructor had had to be dropped. Once more, external pressure was required to support Simmons' request for further change. This time, it came from the AALS via Dean Edwin D. Dickinson of Boalt (who had succeeded McMurray in January 1936). In October 1937, the secretary of the AALS wrote Dickinson that Boalt was in danger of losing AALS membership if it accepted work towards its degree taken by a student from a non-AALS or non-ABA approved law school-to wit, Hastings. Moreover, Boalt's AALS membership was in jeopardy because Hastings, ostensibly an institution of the University preparing students for the bar, was not accredited by the ABA, and the AALS rules prohibited membership to a school if some other agency of the parent university provided substandard legal education. ${ }^{40}$ Dickinson was scared. Simmons was sympathetic-with a purpose. After considerable preparation of his ground, Simmons persuaded the Hastings Board of Directors to invite Dickinson to explain to the Board how Hastings' nonaccreditation threatened Boalt's AALS membership. The historic meeting-historic because never before had an outsider addressed a meeting of the Hastings' Board of Directors-took place on December 20, 1938. ${ }^{41}$ After Dickinson delivered his plea, the Board went into executive session. Simmons' proposal for the addition of a third full-time instructor was referred to the Finance Committee, whose chairman, Charles William Slack, none of his zeal lost for high standards, was ready to act favorably. Yet, what swung the Board's decision in February 1939 to appoint a third full-timer was Simmons' point that 21 states and Hawaii required applicants for the bar to be graduates of ABA-approved law schools. 
On the motion of Slack, Duncan Douglas Low, LL.B. Stanford, '33, associated with Dunne \& Dunne, was hired as a full-time assistant professor effective July 1, 1939 , at a salary of $\$ 3000$. No one was displaced, fees were not increased, and indeed the College was so flush it even hired an additional stenographer.

At the August 1939 ABA convention, Hastings College of the Law was granted provisional approval by the association, bringing the number of approved law schools to 102. William M. Simmons had less than a year to live, one more academic year to direct the College. The ABA approval was a monument to his persistence, his quiet and unspectacular devotion to what he saw as the best interests of Hastings, and to his realization that Hastings could no longer exist in not-so-splendid isolation from the new currents in legal education. The College was prepared for the greatest crisis that would face it. It had achieved professional recognition of its contribution to legal education; it had given pledges to future improvement; and in the first appointment of a second full-time professor since its inception it had in effect chosen the man who would direct it during the coming crisis. Within a month after the ABA convention in San Francisco accredited Hastings, Hitler's panzers crushed Poland and a war of global dimensions began that would ultimately engulf the United States. To William Marvin Simmons' successor fell the task of meeting the strains and stresses of war and peace, a decade of swords and ploughshares. 


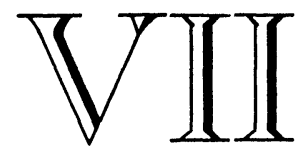

\section{Swords and Ploughshares}

$W_{\text {ith simmons' sudden death less }}$ than a month before the beginning of the new academic year, the Hastings Board made a series of quick decisions which were the most momentous in the College's history. The first was to appoint David Ellington Snodgrass acting dean, at a hastily summoned special meeting with six Directors present on July 31, 1940. Snodgrass, as senior full-time professor, was the only possible choice at such a late date. His salary was increased by $\$ 70$ per month. To find a permanent dean, the Board appointed a search committee composed of the three most active and powerful Directors, Slack, Bosley, and Ehrman. The same Directors were named an executive committee, by Chief Justice Phil S. Gibson, to hire enough instructors to take Simmons' courses. On August 7, this committee met in Slack's offices, and Slack moved the appointment of two men, both with the rank of professor, at $\$ 100$ per month: Orrin Kip McMurray, '93, recently retired as professor of law at Boalt, to teach Conflicts, and Arthur Martin Cathcart, Harvard x1896-97, professor of law emeritus at Stanford, to teach Constitutional Law. Simmons' other courses were apportioned among existing part-time faculty, and a San Francisco attorney, Francis P. Walsh, '26, was hired to teach Bankruptcy. The executive 
committee met again with Snodgrass present on August 12 , to tidy up loose ends. With Snodgrass' acting appointment, Hastings had in fact found the dean that would lead it for almost a quarter of a century; with the appointment of McMurray and Cathcart, the "65 Club" came into existence. Thus were met man and institution which would give to Hastings a unique distinction in American legal education.

If necessity is the mother of invention, accident is the stepfather. Had Simmons' upperclass courses not been Conflicts and Constitutional Law, courses on still rather arcane subjects (from the practitioner's perspective), a couple of practitioners might have been pressed into service at the eleventh hour. As it was, these courses could not be gotten up at the last moment, and they required teaching by a specialist. It was also too late to canvass the law schools for younger teachers. Perforce, retired faculty were the answer: McMurray and Cathcart had specialized in Conflicts and Constitutional Law, respectively, both were available, and both lived in the area. Snodgrass knew them well, had great respect for them, and in hiring them made no long-range commitment. Slack also knew them intimately-McMurray had been a student, and there was a genuine bond of affection between the two. Hastings had no rule requiring mandatory retirement because it had no pension plan. One member of the faculty, Robert W. Harrison, had reached sixty-five in 1937, and was still going strong in 1940; Dean Taylor had quit in his eighty-first year. Indeed, the hiring of McMurray might have foundered, since the University of California had a pension plan and mandatory retirement. However, the University held that Hastings was not part of the University and so was not bound by its retirement rules. McMurray was free to accept employment without jeopardizing his University pension. The shift would work. As yet, though, there was no bold concept in Snodgrass' mind of creating a faculty made up in large part of retired greats from other law schools. Once more necessity (and 
accident) would have to intervene before the architectonic structure of the 65 Club emerged. The intervening graces were not far off, however.

Though the late dean's regard for Snodgrass was evidenced by Simmons' choice of him as the second full-time professor, it was not a foregone conclusion that Snodgrass would be appointed as regular dean. The search committee under Vice-President Slack undertook a thorough search outside Hastings to find the right man. It appears to have considered it advisable to get as dean someone of national standing. A leading contender was Charles Herman Kinnane (LL.B. Illinois, '24, J.S.D. Yale '26), formerly dean at Wyoming and latterly at the University of San Francisco, currently a professor at De Paul. He had, apparently, left USF because of its low academic standards. Kinnane had the "drive and ambition which Dean Simmons did not have, but on the other hand he does not have the charm and culture which he had." 1 Kinnane made the mistake of setting on foot a campaign soliciting telegrams from friends urging his appointment; he was too anxious. The campaign also elicited a particularly crude and vicious poison-pen attack by an anonymous detractor who called into question-without any evidence - the candidate's manliness. This probably had no effect on the search committee's deliberations, but since one of the screeds was directed to President Robert Gordon Sproul it brought his active interest and that of Dean Dickinson of Boalt to the outcome of the search. Certainly more distinguished than Snodgrass, Kinnane maintained his reputation until his untimely death in the mid-1950s. But Snodgrass had taken firm hold of the College's administration, had already demonstrated that executive decisiveness and purposefulness with a touch of panache that would be his hallmark for almost a quartercentury, and he was a thoroughly known quantity. On May 7, 1941, the committee recommended Snodgrass' appointment as dean with a salary of $\$ 7200$; because there was not a quorum of the Board present, the ap- 
pointment had to be ratified at another special meeting of the Board five days later. It was probably never really a close thing, but Snodgrass doubtless breathed easier on May 12. He had no time to savor his triumph. The United States had a year's expansion of its armed forces and rapidly increasing arms production behind it by the time Snodgrass was confirmed in office, Lend-Lease was already a reality, and Pearl Harbor was just seven months away.

The impact on Hastings of the National Emergency and the country's entry into war was immediate and brutal. Nineteen percent of each of the Classes of ' 41 and ' 42 disappeared between their second and third years; in the immediately preceding years, the withdrawal-flunk rate between second and third years had been about 7 or 8 percent. The Class of ' 42 felt the attrition even as the academic year 1941-42 progressed. It began the academic year with 55 students; 15 (27 percent) left at the end of the first semester, in the days immediately following the "day of infamy." Of the 38 in their last semester, only 30 graduated in May 1942; some failed to get the degree for academic reasons, but a few appear to have been called to service even at that late date. The classbook gave the names of 28 classmates already at war, either in the armed forces or in civilian war work, and the editor, Andy Anderson, noted that not many of those graduating would be able to take the 1942 bar examinations, "but there'll come a time when we'll meet again before the bar of justice." 2 More of that class than an historian can record with dispassion would never be met with again. In academic 1941-42, the lower classes suffered proportionate losses. The Class of ' 43 was reduced by 34 percent in the days following Pearl Harbor; the Class of ' 44 , by 39 percent. In all, of the 188 students who began the year in September 1941, 62 left between the first and second semesters, some of them on Monday, December 8, the very morning that President Roosevelt asked Congress for a decla- 
ration of war. If the swords took time to forge, the swordsmen were made in a day.

Worse was yet to come. The table below indicates the withering of the College over the war years. The table gives the enrollment each semester (save the spring semester of 1940-41, for which data are not available), the size of the entering first-year class, and the number graduated at the end of the year (which included some members of earlier classes who had not graduated with their classes because they had had to retake work to make up deficiencies).

$\begin{array}{rrrrc} & \text { Fall } & \text { Spring } & \text { 1st year } & \text { Graduating } \\ 1940-41 & 272 & & 134 & 54 \\ 1941-42 & 188 & 126 & 64 & 32 \\ 1942-43 & 67 & 55 & 15 & 22 \\ 1943-44 & 40 & 37 & 11 & 13 \\ 1944-45 & 44 & 37 & 18 & 8\end{array}$

The Class of ' 45 , comprising 5 women and 3 men, was the second smallest in the College's history-only the Class of '18, with 6 graduates, was smaller. The Class of ' 45 fulfilled the grim prophecy of Dean Albert J. Harno of the University of Illinois to the August 1943 ABA Convention, that with law school enrollments already at about one-sixth what they were in 1938, by fall 1943:

the indications are that this company will have dwindled yet further-indeed, almost to the vanishing point-for we can anticipate that it will then be restricted, with few exceptions, to men classified IV-F and women. ${ }^{3}$

Harno was particularly concerned that standards for admission to the bar might not be maintained because of sentiment for men about to enter the armed forces. Some states had already lowered requirements for admission; California did not. Yet Harno was equally concerned about the need and demand for lawyers, even in-perhaps especially in-wartime, and the fact that because of diminished enrollments, there would be an insufficient supply of young, beginning lawyers. Government service had drawn away many active prac- 
titioners. A genuine shortage of young lawyers existed. As the case of Hastings made clear, the Selective Service System - the draft - hit the law schools more severely than any other professional school. Hastings was grouped with the University of California for Selective Service purposes; the deferment umpire for Berkeley also handled deferment matters for Hastings. The University's archives indicate how relatively poorly Hastings (and Boalt, for that matter) fared in deferments. ${ }^{4}$ The Selective Training and Service Act of 1940, as amended in December 1941, provided for generous deferments for pre-med undergraduates and medical students. Even pre-divinity undergraduates and seminarians did relatively well by the formula that seminaries were entirely postgraduate, requiring a bachelor's degree, and that because of a shortage of ordained ministers, deferment would be given until the divinity degree was obtained. The shortage of lawyers did not weigh heavily in the system. The most that a law student could hope for was completion of a year in progress; usually, he was fortunate to be permitted to complete the semester.

The human dimension was both heartrending and onerous. A state senator (and Hastings alumnus) wrote President Sproul of the University in March 1943 with a plea that a third-year man at Hastings who had just been called into the Air Force be allowed to graduate on the basis of work done to date. Senator Clair Engle, '33, urged that the College "adopt a policy which will give degrees to those young men whose scholastic standings are good and who have completed their courses except for a few months." 5 Sproul referred the matter to Snodgrass. While Snodgrass was sympathetic and acknowledged that allowances had been made in some cases, he held that the problem was so universal he needed ABA clarification. The ABA's wartime rules for approved law schools permitted a senior to graduate short of completion provided he lacked no more than half-a-term of residence and his average to date was that required for graduation. Unhappily, the young man in 
question met neither criterion, and he went to war without receiving his degree. He returned, unscathed, received the LL.B. in 1947, was called to the bar and enjoyed a successful practice, capped by a judgeship, in his native Glenn County.

Despite the fact that the College was desperate for students, fewer women enrolled than might have been expected in light of the opportunity afforded by reduced male competition and the increased demand for lawyers. Certainly, the proportion of women to men students was much increased (the Class of ' 45 was the only one in Hastings' history in which the women graduates outnumbered the men). But in absolute numbers, the 11 women who graduated between 1941 and 1945 were close to the average of 3 women graduates per year that obtained from 1930 to 1945 . The women who did go to Hastings would have gone anyway, being committed for a galaxy of reasons to being lawyers. The war was a liberating experience for women, but the tendency was for women to go into war work, into the women's auxiliaries of the armed forces, into government civilian service, into war industry. Women responded to the same patriotic urge as men, perhaps even more strongly. Rosie the Riveter was legendary but not mythical; Confederate General Longstreet's widow worked in a Los Angeles war plant. Law school seemed tame, even irrelevant, to a great many women, the majority of whom were not particularly careerist and many of whom meant only to make their contribution to the War Effort while awaiting the return of their men and the re-creation of the more tranquil family life which was still the social norm.

The war was also liberating for Hastings. The plummet in student enrollments broke the College's dependence upon the registration fee as the principal source of its income, and forced it to turn to a much higher level of state support. During the late 1930s the annual fee was $\$ 110$; in $1945-46$ it had risen to only $\$ 120$. Because of its specialized nature, indeed its 
"uselessness" to the War Effort, Hastings, unlike universities and even colleges, did not enjoy sudden munificence in the form of government contracts, or in the form of the Army Specialized Training Program (ASTP) and the Navy's famous "V" program, that took students off campus, put them in uniform, and put them back on campus again. Hastings did not have any physical facilities that the government might need; it could not, like the UC agricultural facility at Davis which was taken over by the Signal Corps, be "drafted." It had to go on being a law school, or it had to shut down. The decision ultimately rested with the State of California. Hastings stayed open. The state appropriation of $\$ 41,322$ for biennium 1939-40 was maintained for 1941-42, but was sharply increased for 1943-44 to $\$ 65,072$, and slightly increased for $1945-46$ to $\$ 69,403$. Though the ploughshare years of the GI Bill, 1947-53, saw the annual appropriation return to the statutory $\$ 7000$, the state had taken the decisive step in wartime of providing the College with virtually its entire sustenance. As it was, sustenance was really subsistence, enough to maintain the bare functioning of an institution with only a fraction of its normal student complement, though the fewer students required as much instruction as did the more numerous students pre-war. Three California law schools, Loyola, Santa Clara, and McGeorge, were forced to suspend operation during the war. Hastings did not have to, thanks to the state's assumption of full responsibility for maintaining its program, though on a drastically reduced scale.

The College economized with mounting stringency. The Board considered moving into smaller quarters as enrollments dropped, decided against it, but did save on rent by releasing some space to the state. The main reduction in costs came in progressively reducing course offerings and so reducing payroll. Staffing presented a problem anyway, since war service resulted in some faculty leaving for the duration, including one who was full time. The principal concern was to main- 
tain three full-time faculty to meet the ABA requirement. Academic 1940-41 was a normal year, and with Snodgrass, Low, and the two 65ers, McMurray and Cathcart, there were four full-timers. McMurray left after one year, but Cathcart continued, and 1941-42 presented no staffing problems. Fourteen faculty gave 92 semester units covering the entire curriculum. The need to economize and major staffing problems both arrived in 1942-43. The fall enrollment was only onethird what it had been the previous year. The staffing problem provided the economy. Duncan Low and Francis Walsh went into government service, leaving uncovered first-year Property, second-year Equity, and third-year Code Pleading and Practice (Low's courses), and Walsh's first-year Legal Bibliography and thirdyear Bankruptcy. A retired federal judge in the Virgin Islands and former law professor, Albert Levitt, took Property; a practitioner, Lawrence Baker, was hired part time for Equity; another part-timer, Alden Ames, was brought in for Code Pleading; Legal Bibliography was shifted to an existing part-timer, Edward G. Benard; and Bankruptcy was foregone for the duration. Lyman Henry's second-year Admiralty was also not given, and it remained a casualty until peace. Ira Rowell's second-year Administrative Law disappeared. While Low's absence on leave threatened the continuation of three full-time professors, Levitt supplied the need for the moment. But the entire program was reduced to 88 semester hours.

The radical reduction of both courses and staff came in academic 1943-44. The first-year program was left intact, to serve an entering class of 11 students. There were only 12 students in the second-year class, and 12 in the third. The two upper-classes were combined into a single curriculum of third-year courses, and the second-year courses were cancelled entirely for that year. The result was that only 71 semester hours were offered. Staff adjustments had to be made to gain the benefit of such economy. Things were eased consid- 
erably by the forced retirement of James A. Ballentine, who had long since been reduced to teaching only firstyear courses, but was no longer competent to teach at all. His 11 semester hours, including first-year Agency, Common Law Pleading, and Criminal Law, were parcelled out among others, the bulk going to the indefatigable Robert W. Harrison, who was now teaching 14 hours, and Judge C.J. Goodell (who had joined the faculty the year before). Levitt had quit, along with Rowell; Low and Walsh were still on leave; Benard, Henry, and the stalwart part-timer, Perry Evans, were temporarily laid off. Cathcart's load was reduced from 10 to 6 hours. To maintain the ABA requirement of a third full-time faculty member, the eminent Edward S. Thurston, author of the standard casebook on Restitution and recently retired after a distinguished career, latterly at Harvard, was hired to teach a third-year course in Restitution. Thurston was the third member of the 65 Club. The temporary layoffs of part-time staff were necessary to pay for Thurston's services.

In 1944-45, the third-year curriculum was given, and the second-year curriculum omitted. The thirdyear class of that year took the second-year courses with the new second-year class. Alternating the second-and third-year programs was a brilliant expedient for economizing and making the best use of available staff. In 1944-45, only 58 semester units were given; in 1945-46, the second-year program was put in escrow, and a total of 59 semester hours were given. In each of these latter two years the services of 6 part-time faculty were not used, at considerable savings to the College. Such an expedient, justified though it was by necessity, would have been difficult if not impossible in a more conventional university law school because of tenure restrictions and the hardship that a layoff would work on full-time faculty. Hastings' reliance on part-time faculty who made a good living in practice was a distinct advantage in a time of unusual circumstances. The faculty laid off remained on the College roster, their feelings and 
self-esteem left intact, and they were available for future service.

No essential part of the full curriculum was lost to the students by the system of alternation of the upperclass curricula. The Class of ' 45 graduated with 87 semester units, 2 more than the required number, though there were slightly fewer required units than there had been pre-war. The only courses the students did not have which normally they would have had were all 2-units each: Admiralty, Bankruptcy, and Taxation. Admiralty and Bankruptcy were electives anyway, the former expendable and the latter of understandably limited appeal. Taxation was a significant want, but part of the problem with continuing it was the difficulty of finding someone truly competent to teach it. In retrospect, the graduates of 1945 do not find the experience to have been at all damaging, preferring to tally the gain rather than count the loss. One of the Class of ' 45 recalls that in a course where there were as few as 13 and no more than 25 students, in one hour every student was called upon at least four times. Though unnerving, such over-attention kept the students at a high level of involvement and demanded much more thorough preparation than a larger class would have required. The happy breed, the wartime band of brothers and sisters, are convinced that they received the best education of any students in the College's history. They probably did; certainly they received the most personalized education. The benefits were immediate, for the success rate on the first try of Hastings students taking the Bar Examination was never higher than during these years; the Class of ' 45 (all 8 of them) made it with 100 percent success. It is also worth remarking upon that these students' experience in the system of curricula alternation mocked the conventional wisdom that saw the law school program as one of progressively more difficult courses. Under Hastings' original curriculum-the Pomeroy System - this was doubtless true. But with the triumph of the Langdell/Ames case method and its ap- 
plication to the entire curriculum, at best a distinction could be made between the first-year courses and the whole body of upper-class courses, and that distinction stemmed more from the unfamiliarity of the freshman with the method and the law than from the subject matter itself. By the use of the case method, inherently difficult, even intractable categories of substantive law can be reduced to the same degree of manageableness as simpler categories. The amount of case material used in a course can be adjusted to the degree of difficulty posed by the subject matter of the course. Put crudely, one case is like another; the case method is a great equalizer of subject matter because it is a great simplifier of difficulties. The convention by which the better law schools no longer make any distinction between secondand third-year courses, and each upper-class year is no longer a curriculum in itself, has been a long time coming. Despite its experience of the war years, Hastings did not abolish the distinction until 1971-72.

To David Ellington Snodgrass must go the credit for maintaining a sound curriculum under trying circumstances of indefinite duration. He taught a heavier load (11-12 hours) during these years than any dean in the College's history, while energetically coping with more administrative matters than had his predecessors. Snodgrass even undertook some part-time work for the War Department in 1942-45 (reducing his College salary by $\$ 90$ per month) without sacrificing his teaching. Except for the addition of a stenographer, there was no expansion of administrative staff. Though the Board was always supportive of the dean's efforts, the creativity to conceive of solutions to problems and the initiative to act in confronting them was Snodgrass' own contribution. In this he was ably and devotedly served by the Registrar. Since George Martin's death in 1936, Miss Juanita M. Olsson held that office, the only non-lawyer registrar in Hastings' history. She had been Simmons' secretary from 1925 until her promotion (with precious little salary increase) to Registrar. "Ole," for so she was 
known to a generation of adoring Hastings students and admiring Hastings faculty, was the daughter and stepdaughter of Swedish master-mariners. During the war she found time to take night-courses in navigation, which lent a theoretical dimension to an already accomplished sailor, and had there been a bit more women's liberation then she would have had her ticket. The Registrar handled all routine administrative matters, was the recorder of Directors' meetings, and exercised responsibility for the College's general records and student files. She was librarian besides. During the war years, though Snodgrass' energy never flagged and he gathered more administrative reins into his hands than he could manage to handle, it was "Ole" who provided day-to-day continuity in the College's life. The confusion brought by a constantly shifting student body, curriculum, and staffing pattern was her particular foe; she triumphed over it. She was also the vital, cheerful, kindly, and caring confidante of hundreds of students in these years. For many a young man who received "Greetings" from the President of the United States, "Ole" was the last-always cheery-soul he saw at Hastings when he dropped by to take care of his College affairs. Her memory for student names and faces was famous. And it still is. "Ole" is just as lively and active as ever, albeit on the beach in landlocked Santa Rosa.

January 1944 was as bleak a month for the College's fortunes as the war years produced. There were only 37 students beginning the new semester. The Committee of Bar Examiners, insensitive to the problems raised by war, seemed bent on requiring a higher percentage of success on the bar examination for a law school to remain accredited by the Examiners-with fewer graduates, a few failures multiplied the peril of disaccreditation. It was universally believed that the new year would see the mounting of the grand offensive against Hitler's Fortress Europe-bloody Anzio presaged D-Day six months later-and the massive attack on Japanese con- 
trol of the Central Pacific was well underway, with the Marines suffering 3,000 casualties on Tarawa in three November days. Everyone knew how long losing had taken; no one could be sure how long it would take to win. There was only one ray of sunshine. The Veterans' Administration was beginning to consider seriously what the nation owed those who had served it beyond widows' and childrens' benefits and hospital beds for broken bodies. "Rehabilitation" began to mean also educational assistance, and six months before June 22, 1944, when Roosevelt signed into law the "GI Bill of Rights," the local Veterans Administration office made enquiries of educational institutions as to whether or not they were prepared to contract with the VA for educational rehabilitation. On January 17, 1944, the Board authorized the dean to negotiate a contract with the VA for education of returning veterans, at $\$ 85$ to $\$ 90$ per month per veteran, by which Hastings would accept them, furnish them "with books, fountain pens, pencils, paper, etc. (title to such property to be vested in the College)"6_-Professor Snodgrass had taught Contracts for too many years not to know how to drive a hard bargain.

Dean Snodgrass appreciated the financial bonanza that the GI Bill would prove once it became fully operational. But his enthusiasm for the Bill went beyond motives of gain. During World War I Snodgrass had served on a destroyer as an ensign. He was active in the American Legion, and was the founding father and guiding spirit of the appropriately named Blackstone Post No. 143 of the Legion's Department of California. Returning GIs quipped that though it was not compulsory for a Hastings student-veteran to join the Legion, it was obligatory. During World War II, Snodgrass served as a government appeal agent for Selective Service (1942) and as a member of the state board of the Selective Service System from 1944 to 1947, and he continued to serve the System with the revived postwar draft, receiving a ten-year certificate of appreciation 
from the System in 1962. He was consultant to the chief of the legal branch of the Army's San Francisco Ordnance District, 1943-45, the income from which moved him to reduce voluntarily his Hastings salary, and he contributed further to the war effort as a public panel member of the regional War Labor Board from 1944 to 1946 . The war was no less a personal crusade for him than if he had donned a uniform again. He had enormous sympathy for the plight of servicemen whose education and careers had been interrupted, and he would always take pride in having made available the opportunity for a legal education to as many GIs as could meet admissions qualifications and for whom there were chairs in a classroom.

The challenge of the GIs was formidable. In common with all American educational institutions, Hastings had never experienced either a deluge of students of such proportions or the administrative problems posed by wholesale public support channeled through individual students. In the aftermath of World War I, Hastings had contracted for "vocational education" of disabled veterans with the Federal Board for Vocational Education, but the number of these veterans was small. During the Great Depression, Hastings had participated in the federal Emergency Relief Administration's parttime employment program for needy students. ${ }^{7}$ This program was small (about a score of students were involved at any one time), it was limited to the darkest years of the early part of Roosevelt's administration, and it was administered by the University of California. The College had been slow to develop any form of student assistance. At the outbreak of the second war it shared with Boalt in three scholarship endowments that provided Hastings with three modest grants per year, and the College's first exclusive scholarship (value, $\$ 150$ ) was established in 1939 in honor of the late Warren Olney, Jr., former professor and Board member. Three memorial loan funds had provided some assistance in the 1930s to hardpressed students; such sparse 
student aid had afforded little or no experience in that dimension of administration. The dribble of returning vets that began in August 1945 was too small to do more than familiarize dean and registrar with the myriad VA forms. The deluge of January 1946 exceeded anything that anyone could have expected in terms of numbers and headaches.

The College had prepared as well as it could, but the sudden collapse of Japan and V-J Day, August 15, 1945, took the College, like everyone else, by surprise. Assuming a rapid demobilization, a rush of veterans could be expected at the beginning of the next year. A special session of the College was planned for January 2 to April 27, 1946, the only time in Hastings' history that a new class began other than in the fall. On the day after New Year's, 151 students registered, 86 percent of them veterans. With 60 continuing regular second-semester students, place had to be found for 211 , the same number as in the fall of 1937, and about a score more than in the last "pre-war" fall of 1941. Most of the new students were first-year; the few who were upperclassmen were integrated into the regular secondsemester courses of the second and third years. Dave Snodgrass, who had taught the first half of Contracts in the fall with 29 students, faced a new first-semester Contracts class four times as large. The second semester for the special session students began the day after the end of the first semester, April 28, and ended on August 22. Ten percent of the students did not return, leaving an enrollment of 136, comprising 118 veterans (one of them a woman) and 18 civilians (6 of whom were women). After an exhausting first year, the students who returned in fall 1946 for their second year had the luxury of beginning on September 16, following a summer vacation of a little more than three weeks.

The graph below of fall enrollments, 1940-1953, provides a vivid still-life of swords and ploughshares. It is not difficult to feel the dynamism of the upward curve that characterized the years 1946 to 1949 . And it 


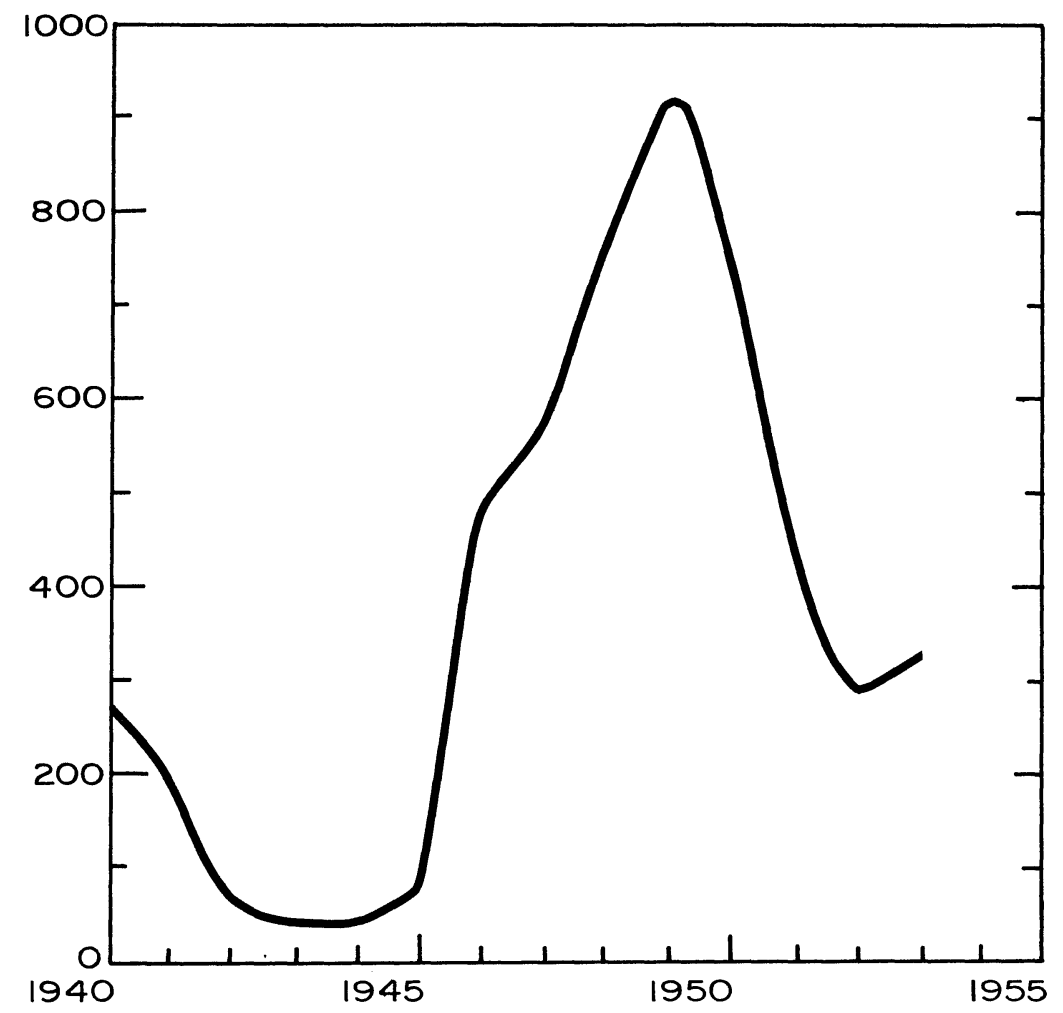

GraPH 4. Fall Enrollments at Hastings, 1940-1953

takes little imagination to recapture the cattlecar conditions of Hastings' classrooms, where no fewer than 483 and as many as 915 students were to learn the law each fall. The California Building at 515 Van Ness had seemed like the Promised Land in 1938 when Hastings moved in. The old State Building had provided Hastings with some 4000 sq. ft. of floorspace; the California Building had 11,160 sq. ft., quite adequate for the largest pre-war enrollments of about 270 students. With a student population of 915, the California Building provided an average of $12 \mathrm{sq}$. ft. per student. The famous Ventilation Ukase of Dean Snodgrass that went out over the Registrar's signature in November 1950 
appears highly amusing today, but it was serious at the time, considering the inadequate ventilation of overcrowded classrooms. Windows had to be kept closed because of Van Ness' heavy traffic noise, but with the huge whirring exhaust fans in each room packed tight with shuffling feet and sniffling noses one strained to hear. Students turned off the fans, "in complete disregard of the welfare of their classmates," and faculty were directed by the Ukase to keep the fans running and to report the name of any student "observed turning off a fan." 8 The fate of the miscreant is not indicated, but the dean's wrath is patent. The terribly crowded conditions during the GI years are remembered with no fondness by anyone.

To accommodate the deluge and to provide at least a passable learning situation, a year's class was divided into two or more sections for instruction in the same courses. By doing this, Hastings stole a march on Boalt (and Stanford too), much to the delight of Snodgrass; during the GI bulge, Boalt's fall enrollment stayed steadily in the upper 200s while Hastings' soared to almost four times that number. In 1946-47, only the first year was divided into two sections. There were two sections thereafter in the first year until in 1949-50, to accommodate the maximum bulge, three sections were established. In 1948-49 and again in 1949-50, the second and third years were given in two sections. The contraction in numbers of GIs in 1950-51 resulted in only two sections being given in all three years, and with a further drop in enrollments, no double sections were required in 1951-52. Another singular break with tradition, or rather a return to Pomeroy's years, when a lone professor had made it necessary, was that classes were given all day long, Monday through Friday, and Saturday classes were extended into the early afternoon. This scheduling began in 1947-48 and continued until double-sections were abolished. The first year was instructed in the afternoon, upper classmen in the morning, enabling them to work, as Hastings students always 
had. In such tight quarters, such shifts were unavoidable if the College was to fulfill Snodgrass' pledge that every qualified veteran would have a chance.

The special sessions of 1946 had been taught by assigning some existing faculty double duty, the hiring of a raft of part-time practitioners, and the addition of two 65ers, Oliver L. McCaskill, who had retired after two decades at Illinois, and Chester G. Vernier, who had spent thirty years at Stanford. Their appointment signalled Snodgrass' commitment to hiring as many retired professors as he could find, and filling in the interstices of faculty needs with part-time staff. In 1947, Augustin Derby of NYU joined the club. Eight 65ers were aboard in 1948-49, though only three, Lawrence Vold (Nebraska and Boston University), Ernest G. Lorenzen (Yale), and George G. Bogert (Chicago) continued over the next year. Bogert was technically a onesemester visitor in spring 1949. The luminous Max Radin of Boalt fell out with Snodgrass after the fall semester 1948 and his resignation was demanded; another Boalt emeritus, Dudley O. McGovney, filled the gap for the second semester. In the last year of the bulge, 1949-1950, William G. Hale of USC and Everett Fraser of Minnesota joined the faculty. Losses of 65ers were few. Discounting McMurray, Radin, and McGovney (who stayed a year or less), the 13 emeriti hired between 1940 and 1949 had given up two to retirement-Thurston in 1948 and Cathcart in 1949and Vernier to death, in 1949. The rest saw the College through the GI bulge and most well beyond. A faculty which in 1939-40 had numbered three full-time, 11 part-time teachers, in 1949-50 comprised 10 full-time ( 7 of them 65ers) and 20 part-time. What had begun in August 1940 as a last minute solution to a desperate situation had grown a decade later to provide the backbone of the faculty and the core of the curriculum. The ramifications of this development were determinative of the next quarter of a century of the College's existence. 
The strain imposed by the deluge (which came more and more to resemble a tidal wave) was considerable. It took its toll on Juanita Olsson's health, and in 1946 she resigned as Registrar. David Ellington Snodgrass, who resembled a great little tower of strength, was clearly overworked. In the fall of 1946, after 14 months of unbroken toil, he was discouraged. He had apparently "given up hope for Hastings," according to an old friend, Warren Seavey at Harvard, to whom he had written about the possibility of finding a job at another law school. ${ }^{9}$ In the event, nothing came of his overture. Some relief came in 1947, when the Board authorized some expansion in administrative staff. A graduate of the College, Arthur M. Sammis, '39, joined the faculty as a part-time instructor to teach Legal Bibliography and first-year Property in 1944-45. In 1947 he was made a full-time professor and Registrar. Sammis had a natural penchant for administration. He remained outwardly cool under pressure, and his sense of order made him a much steadier administrator than Snodgrass. He was a superb lieutenant to the dean at a time when a large part of the routine burden had to be executed by someone in whom the mercurial Snodgrass had complete confidence. Added secretarial help made for a more efficient operation. A librarian-faculty member assumed a burden too long carried by the Registrar. Finally, a coordinator of veterans' affairs was appointed to take over the paperwork involved in the GI program. Yet even with these additions, to the practiced eye of three outside experts who visited in 1948, the school remained "badly understaffed," and they recommended the appointment of an associate dean and an executive secretary. ${ }^{10}$

In dealing with the Veterans' Administration nothing ever proved routine. The VA was the first massive federal bureaucracy with which American higher educational institutions had to deal. For Hastings, the original contract negotiations went smoothly enough. But Public Law 16 and Public Law 346 of 1944 were com- 
plex acts, and the VA was slow to evolve a sound administrative structure to implement them. The local administrators were helpful and easy to work with. Col. Thomas J. Cross was deputy administrator of the local branch of the VA, and Snodgrass had established a close, even warm working relationship with him in 1946. The trouble came in dealing with Washingtonand Washington made the important decisions.

A major problem with the VA arose almost at once after Hastings entered the first contract in 1944. The "GI Bill of Rights," P.L. 346 of 1944, provided for compensation to the host institution on the basis of fees as of June 22, 1944, when it was signed into law. Hastings had always had only one registration fee, charged alike to residents and non-residents of the state of California. In 1941, the Board had rejected the idea of charging a higher fee to non-residents. At the time, the matter was of only academic interest, since the College had very few out-of-state students. The University, however, converted to higher fees for non-resident students as a form of tuition. In 1944, the VA ruled that Boalt would receive $\$ 210$ per semester in compensation for each veteran, resident of the state or not, because it already had its (raised) non-resident fee charge of $\$ 210$. Hastings, however, would receive only $\$ 60$ per semester compensation because that was its highest fee. Snodgrass argued that Hastings was the "law department" of the University by virtue of the act of 1878 and the Supreme Court's decision in Foltz v. Hoge et al.; that the cost of the College's wartime operation amounted to more than $\$ 210$ per student per semester; that even in peacetime student fees had never covered the cost of operation; and that equity demanded that Hastings be reimbursed for veteran training at the same rate as Boalt, to wit, $\$ 210$ per student per semester whether resident or non-resident. While Washington pondered the dean's demand for equal treatment with Boalt and for reversal of the original ruling (and President Sproul puzzled how to deal with Snodgrass' request for the 
University's assistance), the Hastings Board increased the fee for non-resident students to $\$ 210$ per semester effective January 1, 1945. Sproul appears to have delivered the assistance requested; at least Snodgrass thought so. The Veterans Administration ruled that Hastings could establish a non-resident fee comparable to Boalt's, and that if it was applicable to all classes of students, then it would be allowed for compensation of veterans' education. Snodgrass interpreted this to mean that the higher fee was chargeable to a veteran whether resident or non-resident. His interpretation held, though the University in March 1945 put a ceiling on VA fees of $\$ 150$ per semester, thus reducing Hastings' compensation (thanks to the doctrine of parity) to the same sum. ${ }^{11}$ What appears to have been settled in 1945 blew up again in 1949. This time it was the local office that ruled that whether or not Hastings was part of the University was irrelevant, that it did not have the higher fee on June 22, 1944, and therefore it could claim higher compensation only by justifying actual cost of operation. Washington supported the local office. Despite the intervention of Senator William Knowland, in early 1950 Hastings had to capitulate. It could not justify the $\$ 150$ compensation on the basis of cost. Snodgrass agreed in March 1950 to reduce the non-resident fee to $\$ 84.15$ per semester for the current academic year, with a further reduction in 1950-51. In the event, the compensation paid by the VA in 1949-50 was reduced by only about $\$ 25$ per semester. Still, with some bitterness and considerable justice Snodgrass observed that Boalt and even the new law school at UCLA (which was not even in existence in 1944) would continue to be paid the $\$ 150$, without having to justify it by cost, and only because the Regents had had the good luck to adopt a higher non-resident fee before June 22, $1944 .{ }^{12}$

Insofar as cost of operation was concerned, the VA's case was incontrovertible. For the academic years 1946-47 through 1948-49, the College's incomealmost 90 percent of which came from VA 
compensation-was $\$ 740,000$, and its expenditures were $\$ 343,000$, a net surplus of $\$ 397,000$, for a "profit" of 116 percent. In this period, of the 15 state barrecognized law schools in California, Hastings had the second highest income and the fourth highest expenditure (only Stanford, with a total income for these three years of $\$ 776,000$, had a higher income). Tuition paid for veterans comprised only about 60 percent of the total compensation. In terms of actual tuition, the surplus from VA compensation was not excessive: It cost the College $\$ 196$ to educate a student in 1947-48, $\$ 212$ in $1948-49$, and $\$ 201$ in $1949-50$, for which it received from the VA $\$ 300$ per student in the first two academic years, and about $\$ 250$ in the last. The wind fall came from the application fees for veterans, which amounted to about 35 percent of the total VA compensation to the College (summer school fees and handling charges comprised 5 percent). In 1947-48, veterans constituted 88 percent of the student body and brought in 93 percent of the revenue. The next triennium was not such a bonanza time. The reduction of tuition compensation paid by the VA and a decline in the number of new veteran enrollees both arrived in 1950-51, and the decline became a plunge in the next year. But Hastings had made hay while the sun shone. Between 1947 and 1951 , the Board invested about $\$ 390,000$ in securities, many of them safe, low interest bonds. That sum constituted the GI Bill bonanza. In acquiring and banking such a surplus Hastings was not unique; while Hastings cut back its request for state money to the statutory $\$ 7000$ for the period, the University of California received a steadily increasing flow of state money along with the GI Bill bonanza and used its surplus to undertake its enormous postwar expansion.

Did Hastings give good value for money received? It took in more veterans than any other law school in California. In the first four years of the GI deluge, about 18 percent of the state's law school students were enrolled at Hastings. In 1949, Hastings had grown to 
become the tenth largest law school in the country in terms of enrollments. Though it slipped to fourteenth largest in 1950, and to twenty-first in 1951, in every year since 1946 it had more students than any other California law school. It had given more returning servicemen a chance for a legal education than any of its competitors. What its record was in terms of giving an education, not merely a chance for an education, indeed bears scrutiny. If it had taken in more veterans than any other law school in the state from 1949 to 1954 , when the bulk of the veterans completed their studies, it graduated only about 600 of them. In the years 1946 to 1949 , despite its large enrollments, only 106 of its graduates took the bar examination. USC (with 292), USF (142), Boalt (119), and Stanford (112) produced more candidates. More disturbing was the fact that, except for USF, all of these schools had a better pass rate than Hastings; a little over 70 percent from Hastings passed, whereas USC's success rate stood at over 80 percent and Stanford's and Boalt's at over 90 percent. (At just under 70 percent, USF's rate was only slightly worse than Hastings'.) Worse yet, Hastings graduates were on a downward slope on the bar examination results.

The problem was not primarily a matter of quality of instruction. A special survey board of three eminent out-of-state investigators, who scrutinized the entire legal educational and admissions structure of California in 1948-49, visited classes of every full-time teacher and most of the part-time teachers at Hastings and found that "all classroom teaching thus observed was of acceptable quality, and much of it was superior," though handicapped by overcrowding. ${ }^{13}$ It could not have been entirely a matter of examinations and grading standards, because the same panel found that "the questions used meet acceptable standards for examinations in first-rate American law schools," and rated Hastings' standards as "excellent," along with those at Boalt, Santa Clara, Loyola (Los Angeles), and USC; Stanford's were considered only "good" because examination readers 
were used. ${ }^{14}$ Moreover, Hastings excluded a greater number of students at the end of each class-year than any other law school except the night school, San Francisco Law School, and Balboa in San Diego: 23.6 percent at the end of the first year, 16.9 percent at the end of the second, and a big 9.1 at the end of the third. Its percentage of voluntary withdrawals at the end of the first year was lower than most, but still stood at 6.5 percent, bringing the total first-year attrition to over 30 percent. Dean Snodgrass was not joking when he told a first-year class, "Look to the right of you, look to the left of you; the gentleman on your right and the gentleman on your left will not be here next year." 15 The same grim comment could have been made to a second- or a third-year class also. By the beginning of its last semester, the Class of ' 48 had lost 40 percent of its comrades, the Class of '49, 42 percent, and the Class of ' 50,38 percent. There is irrefutable evidence that the faculty was rigorous enough in the classroom, but too lenient at the year-end grade-review session. Too many students (who were, incidentally, anonymous in the review, being identified only by a code number) were upgraded to avoid exclusion. The longstanding Hastings practice of permitting readmission so that a below average grade might be raised to passing level, was used too freely, was even extended to first-year students. Dean Prosser of Boalt accused Hastings of allowing such liberal readmission "for the sole purpose of getting their [the students'] tuition." 16 That was both uncharitable and unprovable.

The root of the problem was that Hastings' admissions standards were too low to afford its marginal students much hope of success on the bar examination. Hastings required less college work than any of the schools whose students did better on the examination, and those same schools excluded fewer students in the course of their program. The bar examination results analyzed by the 1948-49 special survey board established a direct correlation between number of years in 
undergraduate college-and especially in the acquisition of an undergraduate degree-and success on the bar examination. ${ }^{17}$ Hastings and its dean prided themselves on giving a veteran a chance that other schools would not. But the opportunity was not a guarantee of success, and inevitably failure brought misery.

For some, misery appeared to be injustice. Men who had hit the beach at Iwo Jima, thrown back Rundstedt in the "Bulge," dodged flak over Polesti in a B-24, stood fast on the deck of a flat-top as a kamikaze came in, or suffered through winters in Greenland and monsoons in Burma, would not abide injustice. The Class of ' 50 began its last semester with only 62 percent of its starting complement in 1948 surviving. A few days before graduation 47 , or 32 percent of the survivors, were failed and barred from graduating. Most of them were veterans, one of whom was about to fight again as a captain, USMC, in Korea. This academic "slaughter" touched off the sorriest episode in the era of the ploughshares. And it demonstrated beyond doubt that the College, from a commendable desire to give veterans the opportunity to acquire a legal education, had been grossly derelict in not demanding a higher standard for admission and-hard though it might have been-in not excluding more students on the basis of weak records at the end of the first year. Early in July, the 47 formed a committee and requested the Board of Directors to review the examinations of the third-year courses. ${ }^{18}$ The students released their petition to the press. The Board made no reply to the petition. Shortly afterwards, the president of the Hastings Alumni Association called for Snodgrass' resignation! The Board met August 9; it had before it a lengthy "report" with much supporting documentation prepared by the committee for the 47 . The committee requested that the 47 be given the degree so that they would be eligible to take the bar examination in October. The report alleged that the 47 had been failed to assure a better pass-rate 
on the bar examination, the College being in danger of losing its accreditation by the state Bar Examiners because of its low pass-rate (this was a very real peril at the time). In support of this contention, they cited: Dean Snodgrass' current crusade against the Bar Examiners over the accreditation rule; a speech Snodgrass had given to the Class of ' 50 in the previous February pointing out the College's peril and the only remedy, which would be to fail about one-third of the Class of ' 50 ; and a newspaper clipping, reporting his dispute with the Committee, that was mailed out to every one of the 47 failing students with the notice of their failure. Their report gave instances of arbitrary grading practices, of grades changed by the dean after certification of a higher grade by professors, and of direct orders from the administration to professors to reduce grades. The Board did not even open the envelope containing the request and report. The president of the Board, Chief Justice Phil S. Gibson, did, and told one of the leaders of the group to petition the faculty. By this time, the matter was notorious. President Sproul of the University received letters urging him to intervene, and state legislators threatened legislation to correct the "situation" at Hastings. The Bar Examiners Committee had already met with the students and the administration in the attempt to work out a compromise: the "best" of the 47 would be graduated and allowed to take the examinations in October, and the College would retain its accreditation even if there was less than a 60 percent pass-rate. The dean rejected this solution; the 47 would be allowed to retake the third year as the rules allowed-period.

The Directors could no longer wrap themselves in their togas and leave the matter to the faculty, although grades were the latter's responsibility. The Board met again a few days after the August 9 meeting, and called in the dean, who categorically denied the accusations. Rebuking him "violently" for enclosing the clipping with the letters to the failed students, the Board ap- 
pointed a special investigating committee, under the chairmanship of Director Edgar T. Zook, a former judge and son-in-law and partner of Charles William Slack. Zook had the directness and energy of his fatherin-law. His investigation was apparently thorough. He found that the 47 had deserved to fail, that the grades were honest grades by faculty members of integrity, that Snodgrass had not tampered with them, and that what had happened was that the faculty had stopped being lenient in passing students who should fail. Most of the 47 had failed in previous years and been upgraded by the faculty at their annual grade-review meeting or readmitted on examination. On the basis of Zook's report, the Board backed Snodgrass, none dissenting, and directed the chief justice to send a letter to each student indicating that he had failed on his merits and had no justifiable grounds of complaint.

At this remove it cannot be determined which if any of the allegations of arbitrary grade practices instanced in the students' report were true. It is hard to credit that some of them were not, especially those attested to by persons either reporting what they saw and heard, or otherwise in a position to know what occurred. However, the further away the allegations were from 1950 , the more credible they seem-the weightiest evidence was of practices and actions of some years before, not connected with the current dispute, but included for aggravation. Snodgrass' denial of arbitrariness was borne out by Hale and McCaskill, 65ers on the faculty, who admitted that they had been taken by surprise by the large number of failing seniors. The faculty had earlier decided to stop the upgrading of students and to cease allowing a student with a failure to continue. But that new policy was aimed immediately at first- and second-year students. Perhaps with the new policy in mind, the professors had unconsciously tightened standards for the third year as well. It was too late by the June meeting to do much about it, save to upgrade some marginal cases. Snodgrass was responsible for including 
the clipping, but only to indicate that leniency would no longer be accorded failing students. ${ }^{19}$

Snodgrass acted badly in the entire affair. The clipping was a particularly thoughtless act, and appeared to indicate that decimation was undertaken pour encourager les autres. His rigidity in rejecting out of hand the Bar Examiners' compromise solution was perhaps the act of a just man, but it bespoke a lack of equitableness that rests ill in an administrator. And upon Snodgrass' shoulders falls the blame for some of the wellfounded reproaches the students' report directed to the College. At no time, they asserted, had they received any counselling or guidance with respect to their studies, and especially none in regard to their examination papers. Further, they said, the College had neglected to warn them of potential failure at an early stage.

Despite the pressures upon them, the dean, faculty, and Directors held fast. Approximately one-third of the 47 disappeared, a few of them to do a fourth year elsewhere and then try the bar examination. Another third retook the third year at Hastings; 2 failed, but 12 received the LL.B. in 1951. The saddest fate befell the 15 who were eligible to take the bar examination, even though they had not graduated, because they had had four years of legal study (most of them had already retaken the third year once before). Only 2 of these 15 passed the bar examination in October 1950. Of the 84 graduates, most of them Class of ' 50 , who took that same examination for the first time, 57 passed, giving Hastings a respectable success rate of 67.9 percent. The dean and faculty were correct in their assessment of the abilities of the 47 . Thus ended the sad business of the Great Failure Crisis of 1950: Standards were maintained, the College vindicated, but a number of students suffered greatly in the process.

In myriad ways and for eight continuous years the veterans made an impact on Hastings that moved it 
away from its traditional placidity. Sheer bulk was, of course, one of the ways. Never had the College suddenly acquired so many students after having so fewindeed, never had it had so many at all. But more significant was the erosion of old manners and mores by a new breed of students, different in style and tone from their predecessors of previous decades. With the advent of the GIs, for the first time Hastings perceived that students were something more than the young gentlemen in a class who had sat respectfully even when savoring Professor Bryan's startled reaction to a mechanical frog on his podium. Social life ceased to be centered in the nearly-inclusive professional fraternities and the eagerly awaited annual men's smoker, when the dean dealt a mean hand of five-card draw but always remained "the Dean." No money ever changed hands at cards in the presence of William Marvin Simmons, who detested gambling because it was ungentlemanly. Some of the GIs had built up their nest-eggs for "rehabilitation" at cards and craps, and Public Law 346 maintenance was supplemented by some heavy nights of gaming. As a sign of the times, beer gave way to booze when the GIs got down to serious partying. More to the point, faculty found it increasingly inappropriate to allow Socratic interrogation in class to slip over into bullyragging. "Gentlemen" began to give way to "men," and chino pants, if not exactly de rigueur, no longer evoked the stony professorial stare of disapprobation that a few years before had greeted a student not attired in suit and vest. Faculty found that they were not, apparently, as unapproachable as they once had been, and some of them found it difficult to adjust to an easy informality that stopped just short of familiarity with a casually terminal "sir." There was something awesome about so many young men who seemed so mature, battalion commanders before they were of graduate-student age, and flyboys still too young to be served in a Kentish pub.

Unlike their predecessors, these students were cosmopolites. They had not exactly been on the grand 
tour, but they had covered a lot of terrain. The more sensitive of them had acquired a respect for diversity in cultures that gave them a peculiar cast of mind, a certain easiness in dealing with the unfamiliar and even the totally strange. The crudest of them had experienced a great deal and had learned something. None of them were still what they had been when they went off to basic training. Their self-identity had been formed in bizarre places under trying conditions. They did not have to "find" themselves; they knew what they wanted, and they knew what they were going to become. If it could be sung of the Doughboys of 1918, "How can you keep them down on the farm, after they've seen Gay Paree?", it could be said of the GIs that they had seen both more and less than "Gay Paree" (it had disappeared in 1940 when the Wehrmacht goosestepped over the tomb of Le Soldat Inconnu under the Arc de Triomphe). For Americans had tasted for the first time during World War II the whole horror of war and the incivility of barbarism. The GIs always seemed to be in a rush to get started in a "real" life, and their no-nonsense professionalism probably did stem from that impatience. Maybe, though, they were also in a rush to get away from something. Most of them succeeded in rushing into what they wanted in "real" life; none of them managed entirely to get away from the surreal life of so much experience packed into so few years. If in 1941 the swordsman had been made in a day, in 1946 it took a good deal longer to make him into a ploughman.

The GIs were a remarkably stable lot even though they were not stolid. They enjoyed the advantage that the veterans of two wars since have not; they returned as heroes from a victorious struggle for right. They were not so much reintegrated into society; they became society. Here numbers were with them, no GI feeling that he was odd-man-out (that sense was more acute in those who were not GIs). Public Laws 16 and 346 helped enormously, not just financially, but by giving the veteran the assurance that as he had served his country at 

the side of Mars, he would serve it now hand in hand with Athene, goddess both of victory and of wisdom. A grateful nation bid them serve in peace and prosper, and it extended to them the beneficence to make that possible. Purposefulness was not only a matter of idealism, it was also a necessity. The GIs were other than merely men-over half of them were married men. Stability came from stable family lives. The girl married on a 48-hour pass, the girl swooped up after demobilization, proved a rock of loving support. Some of the marriages have not survived the wrack of time, but they were remarkably durable for that season. For the first time in Hastings' history there were wives around in ample number. They were grateful and happy women of high expectation, for their husbands and for themselves as mothers and "helpmates," and if a Hastings model is needed they more closely resembled Mary McHenry Keith than Clara Shortridge Foltz (like both, some of them were law students and proceeded Bachelor of Laws). Married life also served to make the GIs socially and emotionally a good deal more selfsufficient. Their impatience with traditional student life-little though there was of it at Hastings-grew from their own lack of need for it. They were desirous of activity and involvement in real, big issues not confined to or even focussed within the walls of the College. Despite a matchless capacity for delayed gratification and a singleness of purpose that was almost furious, they were politically involved in a way that their predecessors had eschewed.

For all their cosmopolitanism, most of them preserved a measure of provincialism that took the form of a satisfaction at being back where they sprang from. Hastings veterans contained virtually the same proportion of local boys as had their predecessors. First-year entrants averaged 65 percent Bay Area residents for 1945-1949 and 57 percent for 1950-1954; the interwar years saw an average of 68 percent Bay Area residents. The proportion of San Francisco residents was down 
significantly, by about 15 percent of the total entrants, but that reflected the results of two new bridges, some good trains, and a mounting number of cars. The continuation of the dominance of the local constituency in the Hastings student body also had a stabilizing effect. The GIs were home in every sense of the word, and this probably dampened excesses in behavior and reinforced purposefulness.

The veterans comprised a student body which, for the first time in Hastings history, did not include an overwhelming number of students who worked to finance study. The "GI Bill" saw to that. By making possible afternoon classes, this development eased scheduling problems. More significantly, it afforded a priceless opportunity to serious students to devote full time to study. Since there was no way in which the three-year program could be accelerated (because of the strictures of ABA approval and the State Bar accreditation rules), a GI was almost constrained to study at a less tiring pace than his predecessors, successors, and those of his contemporaries who were not veterans. In fact, not as many appear to have taken advantage of this opportunity as one would have expected. There is no hard data to indicate how much employment there was of veterans, but there is indication that many GIs followed the old Hastings practice of working in law offices-if upper-classmen in the afternoon, if first-year students in the morning, when there were no first-year courses given. Why a veteran would work is no mystery. The GI Bill was generous, but it did not provide a luxurious living standard. There was a concern, overall unjustified but in particular cases warranted, that the glut of law students would rapidly saturate the market for lawyers, making it difficult to get a job. A desperation fund brought some ease of mind. Also, by working in a law office, the veteran increased his chances of getting a job immediately upon admission to the bar, if not in the office he had served, then in another office in town on the recommendation of his employer. There 
was no placement office at Hastings (that came only in the 1950s). Before 1946, the widely-known and much trusted "Ole" had been the effectual agent for a great many students in helping them find employment. Snodgrass had gathered that function into his own hands, but was far too busy to handle it well. In the later 1940s, the Alumni Association stirred itself and tried to help with employment, but there was no effectual onsite contact organization at the College to coordinate the alumni's placement activities. Consequently, the veterans' apprehension about jobs, which persuaded them to work though they apparently did not have to, was real enough. Once again, the College was derelict. How many of the less-strong, less well-prepared studentsthe gentlemen who sat on the right or on the left in the first-year courses, and who failed-did so because they worked to earn money, feeling they dare not devote all the needed time to their studies, thus running an unacceptable and too often fatal academic risk?

The veterans at Hastings represented a tidal-wave in more than mass. For the first time in its history, the College found itself following in the train of student initiative. In the 1920s, Dean Harrison had approached the University about the possibility of awarding the A.B. to former undergraduates who had entered Hastings after three years at Berkeley and successfully completed their first year in law school. Nothing had come of it. On March 29, 1947, 77 Hastings veterans wrote Robert Gordon Sproul requesting the same thing. ${ }^{20}$ Their petition was a masterpiece of draftsmanship. They contended that Hastings was "the law department" of the University and that by virtue of that affiliation the privilege extended to Boalt students should be extended to them. They chided Boalt's reluctance to expand to accommodate the GIs; many of them would have gone to Boalt save for this. They pointed out that they had to have the A.B. to do graduate law work, LL.M. and J.S.D. programs requiring an undergraduate degree as well as the LL.B., and that without such 
graduate work they would not be able to use all of their GI benefits. The petition had the approval of Snodgrass, but he was a cockboat in the wake of a dreadnought. Sproul, indifferent to the petition and desirous of burying it, started it into the Berkeley administrative and Academic Senate mazes. The petitioners went back to study, but appointed Raymond Levy, '49, their ramrod. Two years of door knocking and corridorpounding in Berkeley, and a weighty, balanced, and persuasive brief to the University accomplished nothing. In January 1949, the petitioners and their dean opened a second front on a battlefield the University never cares to fight upon. A Hastings alumnusassemblyman introduced a bill in the legislature that would confer the A.B. by act. The imperial curia at Berkeley recognized it was beaten and capitulated. Regents' counsel was quite correct in arguing that the bill was unconstitutional, per Article 9, sect. 9 of the State Constitution-but Jno. U. Calkins, Jr., didn't relish having to take that case to court. ${ }^{21}$ When the University adjudged the matter "closed" in July 1949, 32 Hastings students either had received the undergraduate degree or were in process of receiving it-among them, exramrod Raymond Herbert Levy. Snodgrass enjoyed immensely assuring Sproul that the assembly bill would be withdrawn from the Military Affairs Committee, and his self-satisfaction in acknowledging Sproul's surrender (the only time he signed a letter to Sproul "Cordially yours") was uncontainable. ${ }^{22}$ But the dean had been more an agent than an actor; to the students must go the credit for a brilliant, tenacious, victorious campaign.

With the same kind of verve and determination, students moved Hastings into one part of the law school major leagues. The first number of The Hastings Journal, An Intramural Law Review was issued under date December 1, 1949, with a handsomely printed title page, but a typewritten text. As the dean pointed out in a foreword:

The College officers, burdened with administrative detail resulting from a record enrollment of 915 students, have lacked 
the time in which to encourage such a venture. Due, however, to the industry and initiative of our Associated Students, the preliminary work has been done, and the first issue of the Hastings Journal is a reality. ${ }^{23}$

Subsequent issues were all printed, with the second number the journal assumed its present name, The Hastings Law Journal, and with the fall 1951 issue reference to "intramural" was dropped. The Journal would have been pretty thin, however, without the sterling contributions of a brand new 65er, William Green Hale, formerly of USC, who provided an article in each of the first three issues on his specialty, evidence.

Student initiative also found an outlet in a flowering of new-style student organizations, some of which survive, but most of which bloomed only for a season. The Thurston Society, founded in 1948 in honor of the third 65er to be appointed, Edward S. Thurston, was the College's first honor society, and is still flourishing. Thurston died in February 1948, and his passing was genuinely mourned. After a career at Harvard, he taught his specialty, Torts, at Hastings, using the casebook he had edited with Warren Seavey. The principal student organization, the Associated Students of the Hastings College of the Law, patterned on the one at the University at Berkeley, was the students' most significant development. The Journal was the Associated Students' first achievement, but the organization gave structure to student initiative and endeavor in the whole range of College life. Out of small beginnings, it grew into a formidable institution in the College, so successful that in later years it showed alarming-but impressive-signs of ossification. In its first years it did yeoman service with its housing bureau, though its job placement bureau was not equal to the magnitude of its task. The fraternities continued active, though there had been some attrition (Sigma Delta Kappa, the sorority Kappa Beta Pi, and the Eunomathia Debating Society were gone); a new fraternity was founded in 1948, the Traynor Senate of Delta Theta Phi, named for a former 
Boalt professor, then justice of the California Supreme Court, latterly chief justice and presently Roger B. Traynor Professor of Law at Hastings, that eminent gentleman himself.

The ephemeral but numerous special interest clubs, most of them addressed principally to topics of current concern, were yeasty. One is hard put to find a radical of any hue in pre-war Hastings. One stalwart counsel for unpopular causes, who came to a lively awareness of the plight of the under-represented illhoused and ill-fed of the Depression era via involvement with the labor movement of the 1930s, was Ben Margolis, '31. There were two or three other students who were much exercised by the plight of labor in the age of its classical struggle for full recognition. But they were very much a few lone voices crying in the wilderness of a very staid Hastings. All of them were too busy studying and working to support themselves to find much time for causes, and the underdeveloped student life of the lunch-box college made the formation of political clubs almost impossible. Clair Engle, '33, parlayed an active political involvement as an undergraduate at Berkeley into a long career in California politics, but at Hastings his nose was to the grindstone. ${ }^{24}$ Some, like Myer C. Symonds, '33, found it possible in later years in practice to fight for liberal causes. Only with the GIs came the opportunity for political and ideological diversity to find an outlet in student political activity. Besides the usual polarities of Democrats and Republicans, both of which found warm supporters among the GIs in the hotly contested election of 1948 , Henry Wallace's breakaway Progressives could claim some adherents in the California Building. To Snodgrass' dismay, the National Lawyers Guild formed a small but active chapter at Hastings. In the mounting McCarthyism of the late 1940s, the NLG was looked upon with increasing suspicion and was on its way to a place on the Attorney General's list of subversive organizations. Snodgrass could not bring himself to join 
even the American Civil Liberties Union, despite the blandishments of a member of the Class of '51, Lawrence Speiser, who entered the ACLU's San Francisco office as a staff counsel shortly after graduation. ${ }^{25}$ The phenomenon of political organizations and professional organizations with political purposes appearing in educational institutions was a universal one in the late 1940 s, and a contribution of the veterans. The proliferation had a great deal to do with the organizational sophistication of young men who at an impressionable age went almost directly from family to a very well structured architectonic society called the army. It took a period for the GIs to de-organize themselves. That there was a definite political cast to so many student organizations might have had less to do with ideology, or even profound dissatisfaction, than with an understandable desire to create a brave new world in the shortest possible time.

That brave new world had to have, by common agreement of the GIs and others who were not but were sensitive to their aspirations, a place in it for all Americans. The war created a rare patriotism, one that was sentimentally inclusive rather than exclusive. Even in the tragic and strange aberration of the internment of the Japanese-Americans, the inclusive quality of the patriotic fervor served first to mollify and then to shame occidental Americans for the way they had treated these oriental fellow countrymen. In Nazi Germany especially, Americans were offered a vision of the dreadful fruits of hate, especially of racial hatred. It is easily overlooked that what we today call "affirmative action" was first essayed, and across the board of national economic life, by an executive order of May 27, 1943. Aimed at safeguarding the rights of Blacks to partake of the full employment that war industry provided, the order required mandatory incorporation of nondiscrimination clauses in contracts for war materials. Despite race riots and strikes against hiring Black labor, despite Congressional and legislative reactionaries attempting to block 
civil rights legislation (and succeeding all too well), the temper of youth-the temper of GIs-had turned against racial discrimination. Hastings' first Black graduate, Thomas Lucius Berkley, '43, was a pioneer in more ways than one. He dealt with residual and not even faintly disguised discrimination on the part of some of his professors, but he enjoyed the tangible support of his classmates in his forthright, firm, and polite rejection of second-class status. For the first time, in the ploughshare era a significant number of Blacks found it economically feasible and wholly appropriate to get a legal education at Hastings. Terry Francois, '49, Horace LeRoy Cannon, '52, Carl B. Metoyer, '52, George G. Walker, '52, and Hiawatha T. Roberts, '53, have all risen to professional, and some to political, eminence. Lionel J. Wilson, '49, recently gave up a superior court judgeship to win election as Oakland's first Black mayor. Wiley W. Manuel, '53, became California's first Black supreme court justice in 1977. He believes that three attorneys made decisive breakthroughs in the Bay Area for the practice of the law by Blacks: Thomas Berkley, whose thorough preparation for practice signalled a new professionalism; Carl Metoyer, whose intellectual distinction went beyond mere learnedness; and Clinton W. White, Boalt '48, whose reputation as an advocate made him one of California's major criminal lawyers. Hastings' score, 2; Boalt, 1! Justice Manuel's own contribution is evident.

The GIs set the standards, provided the objectives, and dictated the direction of student life between 1946 and 1954. Those of their fellow students who were not veterans, including those too young to fight who came to Hastings in the ploughshare years, accepted the GIs' leadership, and often consciously, always at least subconsciously, imitated them. The graduates of the generation of the ploughshares are today a bit paunchy, perhaps somewhat less enthusiastic than they were then, but they are now at the height of their powers and their power. At last count, there were about 180 Hastings graduates on the bench in California and elsewhere; 40 
percent of them were of the Classes '46-'54. Graduates of the era are leaders at the bar. Yet their generation was not condemned to serve a long apprenticeship before they had a chance to do something significant in their society. They made their mark, a remarkably indelible one, while they were still fledglings. Hastings was the beneficiary then, society is today.

The legacy of bricks and stones, the immediate substantial legacy of the GIs, was the first home for Hastings College of the Law that it could call its own. Though most of the veterans, those who sweated and strained to hear in the overcrowded classrooms in the California Building on Van Ness were not able to appreciate it, the new building that the College occupied in the spring of 1953 was made possible because of their sufferings. Their mass moved the state to provide, three-quarters of a century after Serranus Clinton Hastings' gift, truly adequate facilities for the teaching of the law in the oldest law school in the West.

It is probable that from the outset of his tenure David Snodgrass intended to build a permanent home for the College. He was a builder by instinct, with a sense of space and an eye for decoration. As a student at Harvard Law School in the early 1920s, he might well have shared in both the admiration for Langdell Hall's imposing Classical portico with its severe, unfluted columns of the Ionic Order, and the prevailing distaste for a building that was curiously bobtailed because the entire structure had not been continued far enough to provide symmetry, and the facade looked uncompleted. Langdell received its present finished state only in 1928. Snodgrass had travelled in Europe in 1921 just after his graduation, and he was not too old to feel that awe reserved for the American when he first sees the great monuments of the culture, not Richardson Romanesque (like Dana Hall at Harvard Law School) but real Romanesque, A.D. 1100. The development of Snodgrass' architectural sensibilities might have stopped short of real aesthetics, but he had acquired the taste for 
imposing buildings and a good notion of what makes a building imposing. That proved to be relevant. The present Hastings College of the Law at 198 McAllister Street owed more to him in utilization of site, space arrangement, and the appearance of the front, or facade, than it did to the architect responsible for it.

Again in the dreary year 1944, Snodgrass had sought to realize a dream. On August 23, he proposed to the Directors that "serious consideration" be given to acquiring "a building of its own for Hastings College after the war," and Slack, Ehrman, and Maurice Harrison were appointed a committee to decide "ways and means" to provide such a building. ${ }^{26}$ There was no question raised as to whether or not to build, only how it was to be done.

With peace and the deluge of GIs, the College began serious planning. In late 1946, Hastings requested of the Department of Finance a $\$ 900,000$ appropriation for building. The Department put a hard question to the University: Why shouldn't the Regents request the construction as part of the University's building program ${ }^{27}$ Sproul, reluctant to raise the wholly thorny question of affiliation and the relationship between the two institutions, disclaimed all responsibility for such a building on the grounds that Hastings had not presented a request to the Regents. Snodgrass decided to move by a more direct route. He informed the Director of Finance that because of VA revenue, the College would make no extraordinary budget request for the biennium, requiring only the statutory $\$ 7000$. This made the legislature well-disposed to two bills introduced in early 1947 by friends of Hastings for an appropriation of $\$ 1,200,000$ for the building. ${ }^{28}$ The University, fearful that it could not stop the bandwagon, decided to try to drive it. It did not have much choice, since the bills called for the money to be appropriated to the Regents. The Regents had their own interests to protect: The University had a special appropriation bill in the hopper to provide $\$ 1,000,000$ for the proposed 
law school at UCLA. James H. Corley, the University comptroller, was directed to cooperate with Hastings, and the University architect's office entered into discussions with Snodgrass as to the proposed building's size and requirements. It soon became clear that $\$ 1,450,000$ was necessary, and the bills (one in the senate, the other in the assembly) were amended accordingly. On July 18,1947 , the governor signed the appropriation of $\$ 1,450,000$ for Hastings and another of $\$ 1,000,000$ for UCLA. ${ }^{29}$

For the first time in the "common law" marriage of Hastings and the University, the somewhat reluctant and always guarded "partners" had to work together. The Regents had responsibility for the disbursement of the appropriation; moreover, the College needed the assistance of the University's office of architects and engineers in planning and executing a project of a kind and size that was beyond the capacity of anyone at Hastings. By and large the collaboration went smoothly. The only sticking point with the Regents came over whether or not the interest accruing over the years on the unspent appropriation should go into the Regents' building fund or be applied to the Hastings project. The University administration recommended the latter, and though this was resisted by the Regents, it was finally approved (thanks in part to Directors Ehrman and Harrison, who were also Regents, coming to the College's aid). The Regents were surprised and grateful at the Board's willingness to provide a $\$ 50,000$ guarantee out of the GI bonanza against overrun costs. The collaboration with the president's office was particularly remarkable, thanks to unusual forebearance on Snodgrass' part and the fact that he dealt with the comptroller, Jim Corley, who won the dean's undying respect and in turn came to have a real affection for Snodgrass and Hastings. The University architect, Louis DeMonte, a man of strong views but considerable flexibility in negotiation, found Snodgrass cooperative. It is just possible that Snodgrass has the distinction of being the only academic 
who ever persuaded DeMonte to accept major architectural revisions that ran counter to the architect's wellinformed judgment. The two worked well together and with the outside project-architect.

Almost six years elapsed before the new building was occupied. Snodgrass took time to choose the right site, and he was reluctant to jump into an inflated building market. He also wanted to make sure that the structure would be adequate to the College's longterm needs, and he was prepared to wait to see how enrollments progressed. His caution proved to be correct. His first impulse was to build downtown in the MontgomerySacramento-Clay area for easier accessibility for parttime faculty and students working in the business and legal district. That would have been a mistake, as the College's reliance on part-time teachers was rapidly disappearing and, though he could not have foreseen it, traffic congestion would become worse there than in the Civic Center. The original estimate called for 30,500 sq. ft. of usable area, accommodating 500 students; the experience of the late 1940 s persuaded him that 48,500 sq. ft. with a capacity of up to 1000 students was better. Time has proven him correct.

By the end of 1948, it was decided that the College should remain in the Civic Center, and negotiations were begun to purchase the $24,000 \mathrm{sq}$. $\mathrm{ft}$. lot at the northeast corner of McAllister and Hyde. ${ }^{30}$ Opposition to the move from organizations that saw the tax revenues that would be lost by conversion of this commercial property to educational use came too late to prevent the purchase; the alternative sites suggested were not suitable anyway. The outside architect was selected in 1949; largely at the urging of the University architect, Masten and Hurd was chosen rather than Wurster, Bernardi, and Emmons. Masten and Hurd had designed a great many public buildings: Letterman Hospital, Kezar Stadium, Children's Hospital (San Francisco), Merritt Hospital in Oakland, the University Press Building in Berkeley, and the Shasta County Jail were among their 
works. None of these buildings soar with inspiration, but they are solid, perhaps a touch too New-DealFederal in spirit. Indeed, the Hastings building proved to be rather more pleasing to the eye than the others; it is certainly more impressive than the squat boxyfacaded new Boalt Hall (completed in 1951) that has been mercifully screened by the trees that have also hidden brave words of Holmes and Cardozo. Yet Bill Wurster and his associates might well have produced a more imaginative structure and one that would not have become dated quite so quickly as the design that was built.

Though there was a building committee throughout the planning of the edifice which included some of the 65ers, Registrar Sammis, latterly two Directors, and DeMonte in an advisory capacity, the man responsible for the plan was Snodgrass. At the first meeting, after a brief presentation by Oliver McCaskill of what, from his long experience at Illinois, he believed a law school building must contain, Snodgrass presented his ideas. ${ }^{31}$ Except in one respect, the building that we see today conforms to his presentation. He proposed that there be one floor below ground and three above-the basement level as the service area for the students, the ground floor for the major classrooms, administrative offices on the second floor, and faculty offices and library on the third floor. The space on the third floor proved to be inadequate to house both the faculty offices and a 100,000-volume library; consequently, the faculty offices were moved to the second floor (along with smaller classrooms) and the administrative offices were put on a mezzanine, which is architecturally very neatly executed and aesthetically very pleasing. At every stage, as the plan underwent minor modification and the design developed, Snodgrass had the last word. It was at his insistence that the classrooms were put in the interior of the building without windows-he had suffered from street noise too long in the State Building and the California Building to abide ever hearing another backfire, revving engine, squeal of brakes, or sound 
truck in first-year Contracts. The infinite pains taken with acoustics, including bringing in a UCLA physicist to design very nearly perfect acoustics, was his idea. No one would have to talk louder than in a conversational voice even in a classroom with 200 students, sound amplification would be unnecessary, and no one would dare whisper during class because it could be heard across the room. The ventilating system was as sophisticated as it could be without air-conditioning, and there would be no way a student could turn it off, or would there be any reason to do so. Finally, the terrace stemmed from a country-boy's desire to have at least a bit of open space, some "campus" even if it had no grass, in the middle of the city. The students of a quartercentury who have lounged in the sun on the terrace have the dean from Selma to thank for providing what might easily have been considered unnecessary and wasteful of space.

Groundbreaking took place on November 30, 1950. The construction went slowly, but Snodgrass took infinite pains in matters of detailed space utilization and even in decoration, and the slow pace enabled him to keep "on site" supervision under his own eye. Strikes delayed the work. Cost overruns proved troublesome, but not insuperable. Finally, in late winter of 1952-53, the dream was a reality and ready for occupancy. It was a handsome building. The facade was imposing-no Ionic Order, indeed, but the louvred lights gave a bold appearance, avoiding an impression of fragility but also preventing the massive heaviness that would have resulted if the louvres had not broken the box-like lines of the great square windows. The interior was thoroughly functional and almost luxuriously elegant. The classrooms and moot courtroom were perfectly furnished. There was finally room for Charles William Slack's library, and the reading room was named in his honor. Open stacks for the first time seemed to invite Hastings students into the world of books. And there were offices for all the faculty, a common room for 
them to meet in, and ample space for student activities. All in all a splendid achievement.

The new building came on the wave of new law school building everywhere. Within three years all of the state-funded law schools in California-Boalt, UCLA, and Hastings-acquired new quarters. Other big city law schools like NYU and Temple built anew. The University of Illinois, the University of Texas, and smaller schools such as the University of New Mexico and the University of Richmond found new housing. Hastings had waited three-quarters of a century for the day when it would have a home. There was an added element of satisfaction that it was part of a nationwide renewal.

On March 26, 1953, the 75th anniversary of the Act of 1878 establishing Hastings, the new edifice that had hardly yet been occupied was dedicated. The same chief justice and president of the Board, Phil S. Gibson, who had been present at the meeting that appointed David Ellington Snodgrass acting dean thirteen years before, was in the chair. The terrace was packed with dignitaries, the faculty and Directors, representatives of other law schools, legislators, and judges. Governor Earl Warren (soon to be named Chief Justice of the United States) bulked large on the platform. Clark Kerr, provost of the University, represented it in the absence of Robert Gordon Sproul. ${ }^{32}$ The speeches were appropriate to the occasion, laudatory and solemn, pleasing to the ear. The principal address was given by the president of the Association of American Law Schools, Charles B. Nutting, vice-chancellor and dean of the law school at the University of Pittsburgh. His presence was itself testimony to new-found recognition-Hastings had been readmitted to the AALS in 1949. Earnest, evoking the past, assessing the present, even essaying a prophecy for the future, he spoke about the training of lawyers for the future. Nutting concluded on a rising note:

Through the years you have prospered and grown strong. 
You are now in the full vigor of maturity. You have the enthusiasm which comes from the recognition which has been given you by those who have supplied you with this beautiful building. All these things speak well for the future. Perhaps, with the long look of prophecy, I can see the day when we gather to celebrate the one hundredth anniversary of the Hastings College of Law and to congratulate it for pioneering in yet another field..$^{33}$

Prophecy is always dangerous. Much of the direction that legal education took since his words were spoken fell short of his prediction, much came long that he did not foresee. Many there that day will not be here for the one-hundredth anniversary. But there is a very good chance that Professor Charles B. Nutting, a member of the 65 Club at Hastings since 1972, will be.

David Ellington Snodgrass will not be present. Those who are might, as they sit on the terrace of 198 McAllister, reflect on the aptness of a borrowed epitaph applied to its builder: Si monumentum requiris, circumspice, If you seek his monument, look about you. 


\section{VIIII David and the Goliaths}

David Ellington Snodgrass resembled his Old Testament namesake in more ways than one. He was short, bright eyed, swift in movement, active, a countryman, and he rose from humble station to a position of power-all of which was said of David. Granted he was not a musician and poet to the measure of the Psalmist, but he was clothed in the armor of righteousness, he feared not the lion or the bear, and he would slay more than one Goliath, one Philistine, in his life,

And all this assembly shall know that the Lord saveth not with sword and spear: for the battle is the Lord's, and he will give you into our hands. [I Samuel 17: 47]

Like David, he enjoyed the power of imperium and he built a "city of David" in Hastings. Passion, tenderness, generosity, fierceness were his attributes, and in psyche he was no less complex.

David Snodgrass was born in Selma, Fresno County, in 1894. His father came to California from Tennessee in the 1880 s, scion of a solid family that had produced a judge. The only work the elder Snodgrass could find was digging potatoes in San Joaquin County at a half-dollar a day for a 12-hour day. He had taught school in Tennessee and one day, disgusted with his present work and the wages, he threw down his hoe and 
went back to the blackboard. When he died he was president of five small banks; David's younger brother went into the same line. A college friend remembered David's mother as being "a lovely, intelligent, and towards David, indulgent woman." In 1912, David went to the University of California, Berkeley, where he spent three years and earned the reputation of being a bookworm. Rather than be forced to take compulsory military training at the University, which he found intolerable, he quit for a year and then went to Harvard as a senior. He took his A.B. there in 1917, finishing with a creditable record and an enviable reputation as a pinochle player. After war service in the Navy, he entered Harvard Law School, and graduated LL.B. in 1921.

The two men Snodgrass most admired at Harvard were Dean Roscoe Pound and Professor Samuel Williston. From Pound, he acquired an abiding respect for the common law as a tradition and a system. Pound was a Westerner, too, from Nebraska, and the Californian found it easy to identify with him. At Hastings, Snodgrass sported the same green eyeshade that was Pound's coronet-not entirely from respect or affectation, but because bright light really did bother Snodgrass (a sensitivity that resulted in the well-designed soft lighting at 198 McAllister). ${ }^{2}$ He kept up correspondence with Pound, and he dearly wished that Pound might have come to Hastings as a 65er; instead, UCLA claimed him for a summer session. His affection for Pound was requited, for while Snodgrass' relations with Pound's successor as dean at Harvard, Erwin Griswold, were sometimes stormy, Pound always took pride in his old student in San Francisco. From Williston, Snodgrass learned Contracts. Williston was not only a poised and polished classroom performer, a dialectician without peer, but he had had considerable experience in practice. Snodgrass admired Williston's combination of academic brilliance and practitioner's good sense. Williston stood for the proposition that a lawyer must develop real profundity in command of the law, and 
that profundity began in the first year where comprehension of ideas rather than a kaleidoscopic grasp of the law was the object of study. Snodgrass followed Williston closely, both in teaching Contracts, and in practicing the master's oft-repeated precept: Non multa sed multum, Not many things, but much. ${ }^{3}$

Snodgrass practiced for awhile in Illinois, but returned to San Francisco in 1924. He began teaching as a part-time instructor at Hastings' night school "step daughter," San Francisco Law School, in 1925. He served a year as secretary to Federal District Judge Frank H. Kerrigan. Kerrigan was a shrewd and learned man, with wide-ranging political connections and a sense of how to get things done in government. It was a useful apprenticeship for young Snodgrass. He began teaching at Hastings in 1928, giving upper-class courses in Trusts and Future Interests. His chance to teach Contracts came in 1930, and from then until his death he taught it regularly; Williston long remained his casebook. In 1927 he had become a house counsel with the Tidewater Associated Oil Company, specializing in sales work, and remained with the company until he became a full-time professor at Hastings in 1936. He never practiced again, though he was unstinting of his time in giving an opinion gratis to old students and old friends who asked for his expertise. Though specializing in Contracts and Sales, he taught Suretyship, Trusts, Mortgages, Common Law Pleading, and (reluctantly) Domestic Relations. He knew his limitations: Some years after he had last taught Suretyship, he refused to review a case book in the subject on the grounds that he was both too busy and too rusty in the subject.

Snodgrass was not a scholar in the sense that term had come to be understood by the time he entered academia. He authored no casebook, his contributions to journals were limited to book reviews, and he would never have considered writing a treatise or monograph. Yet he was scholarly, in that he knew when scholarship was good (and praised it), and when it was bad (ex- 
coriated it). He kept thoroughly abreast of developments in Contracts, and though his own notion of the way to teach the subject tended to be conservative, he accepted the value of others' attempts to teach it differently. He liked practicality. Reviewing a new handbook on the law of contracts, he neatly sidestepped a couple of very hot current issues - the dispute between Langdellianism and Realism, and whether a handbook becomes a crutch for weak students by serving as a substitute for close case analysis-and gave the handbook a benediction that revealed his own pragmatism and experience:

The new text is richly endowed with the common sense and class room judgment which were to be expected of an author who has taught in a "city" law school for more than a quarter of a century. ${ }^{4}$

Snodgrass enjoyed teaching, finding it stimulating and in turn making it stimulating for his students. But the law always remained for him personally a matter of practice, not theory. Long after he had had to give up practice, he recalled with pleasure a leading case before the state supreme court in which he was co-counsel for Tidewater, and there was a note of envy in his words to an old student, "You are a lucky man, to be engaged in the practice of the law." 5

Snodgrass was famous for his wit. Some who knew him call it "trenchant"; others, "caustic." It was both, and the distinction was one of degree, not of kind. Directed at a slow student in first-year Contracts, "caustic" became "sarcastic," and many old students still smart under a destructive quip delivered years ago. By and large, the faculty appreciated his skill with a bon mot, but since they were nearly his equals in role and generally his seniors in age, they were seldom on the receiving end of his wit. His peers in the world of law school deans sometimes smarted under it. Dean Griswold of Harvard was not amused. Dean Prosser of Boalt could give as good as he got, and had the distinction of being one of 
the very few who often managed to win an exchange. Dean Coffman of UCLA never took offense, and Snodgrass in full cry was a source of considerable amusement to him. Snodgrass could be devastating: addressing an old student by his first name who had written Snodgrass crowing about a case he had won for an electric company, the dean commented that to a

Professor of Contracts, Sales and Trusts, a case in which the electrocution of a small child has resulted in the enlargement of a law office is not a pretty thing. In devoting more than 100 pages of type to the facts, you excluded the possibility that an artistic treatment of legal principles should be made. ${ }^{6}$

His wit was generally appreciated by audiences who heard him speak. He seldom used a prepared text and his speech was never available in writing after it was given. He was at his best after dinner, and fortified by Old Bushmills he was incautious, naughty-and very funny.

A tender side to Snodgrass shone through, especially in correspondence with old students. A letter to a Mexican-American alumnus aspiring to political office was full of encouragement, sound advice, and genuine affection. An alumnus who had been disciplined for misconduct wrote Snodgrass of his reinstatement and acknowledged with gratitude "the friendship and the guidance of certain men like yourself. ..."7 A letter of apology from an old friend and fraternity brother for apparently uncomplimentary remarks directed at Snodgrass at a meeting where they were both present elicited from Snodgrass a demurrer to the apology "for remarks which, from my point of view, were intended to be humorous, rather than offensive,... Please give the matter no further thought. You will never hear of it again, from me." 8 A newly-appointed superior court judge wrote the dean thanking him for his letter of congratulations, and volunteered a compliment that summed up the way a generation of students remembered Snodgrass: 
I have always thought of and remembered you, since I was one of your brood at Hastings, as a learned man, an excellent instructor, and last, but by no means least, a "darn good fellow." Being of a sympathetic nature, I regret to see disappointment come into the lives of those who try. At times I felt that some of the instructors at Hastings were rather heartless in their attitude toward the students. This attitude may or may not be necessary or advisable in view of the great number aspiring to become members of our profession. But be that as it may, I always felt that there was in your heart a wealth of sympathy for those who just couldn't make the grade. ${ }^{9}$

These words ought to be remembered in reflecting upon the Great Failure Crisis of 1950.

Politics held infinite fascination for David Snodgrass. Though he never sought office, he liked the company of politicians, he was wise enough to realize that he would need their assistance almost continuously, and he never shrank from delivering himself on a political matter when he felt the occasion appropriate. His political loyalties were complicated and mixed. A registered Republican, he maintained warm relations with Democratic congressmen and state legislators (many of them Hastings graduates). When he campaigned publicly for Republican Goodwin Knight in his gubernatorial race in 1954, Snodgrass' support grew from Knight's advocacy of veterans' benefits rather than from his party. Snodgrass did not admire Earl Warren either as governor or Chief Justice of the United States; Warren was too liberal for Snodgrass. He detested "leftwingers," and he drew the line between left and center and right a good deal further to the right than most of his contemporaries in academia in the late 1940s and early 1950 s. Circumstances spared him the necessity of having to deal with the disruptive issue that stalked the universities at this time-whether a past or present member of the Communist Party was fit to teach. Because Hastings was not subject to the Regents of the University of California, the loyalty oath imposed by the Regents on the University in March 1949 did not extend to Hastings. The Hastings faculty included no young, hot liber- 
als, and it is unlikely that any would have refused such an oath; there was no opposition to the statewide oath required by the Levering Act of 1950. Only Max Radin might have been prone to take a libertarian stance on the oath matter, but his falling out with Snodgrass caused him to leave before the Levering Act. Had an oath controversy arisen at Hastings, there can be little doubt about the outcome. Directors Ehrman and Harrison, as Regents of the University, were hard-liners in the oath crisis, and with Snodgrass' rightward leanings at one with the Board's conservatism, a faculty member refusing the oath would have been fired instantly. Snodgrass would not lend his name to a spectrum of causes ranging from the National Lawyers Guild (which was well on the left) to the American Civil Liberties Union. Moreover, he played a leading role, through the local American Legion, in initiating the unsuccessful disbarment proceedings brought against Richard Gladstein, Boalt ' 31 , in the aftermath of Gladstein's strenuous and strident defense of the Party members in the 1948 Smith Act trial in New York.

For all of his conservatism, there was a touch of old-fashioned populism in Snodgrass. He preserved the small-farmer mistrust of big money and big property that colored the San Joaquin Valley in his youth. He recalled the hard times of Valley farmers in the first three decades of this century. He was much agitated by the possibility that the United Nations Declaration on Human Rights might abrogate American control over immigration into the United States. Snodgrass didn't like the John Foster Dulles variety of executive agreements, even if they were used as a means of assuring allies in the Cold War; his detestation for the Soviet Union did not extend so far as to accept a threat to the integrity of the "supremacy of our Federal Constitution." 10 As a lawyer, Snodgrass could be expected to favor the campaign of Senator Thomas C. Hennings, $\mathrm{Jr}$., in 1960, against excessive secrecy in Federal civil litigation. But Snodgrass was also concerned by the per- 
nicious side to Congressional investigations that the McCarthy era demonstrated, and he was in favor of legislative review to avoid the worst features of the current system. Finally, despite his service in the First World War and his patriotic civilian activity in the Second, despite his vehement opposition to Communism and his adherence to the American Legion's brand of patriotism, Snodgrass disliked the Korean War intensely, not because it was "Truman's War," but because it was unnecessarily disruptive of America's life so soon after the unremitting effort of World War II.

There are some features of Snodgrass that can easily be overlooked, but which are revealing. He was genuinely gregarious. He was an avid attender of AALS annual meetings, American Law Institute meetings, and when he could find the time, ABA conventions. He travelled a great deal in the state talking to local bar associations, service clubs, professional groups, and Hastings alumni organizations. He entertained prodigally at the Bohemian Club every visiting firemanwhether "useful" to him or not-who came to town. He enjoyed good company; dull people bored him, but he was generally civil to everyone. He also had an authentic concern with making equal protection of the law available to everyone. At Harvard he had been active in the legal aid clinic. In San Francisco, he was a strong supporter of legal aid to the poor, and to that work he gave a great deal of time that he did not have to spare. Snodgrass possessed a real sensitivity to the needs of those who could not afford to purchase legal assistance. Finally, Snodgrass liked animals. He was a devoted contributor of effort and money to the SPCA. The finest piece of writing he ever did was "Old Dog Tray Goes to Court," a witty, light, touching essay in the law governing canines. ${ }^{11}$ It has been said that a man who likes animals can't be all bad. More correctly, it can be observed that a man who likes animals has a capacity for compassion, a predilection to take the part of the underdog. 
To contemporaries, Snodgrass appeared to have too strong a penchant for publicity and self-advertisement. $\mathrm{He}$ is the first and the last Hastings figure who can almost be chronicled from back-issues of national magazines and local papers. There is no doubt that Snodgrass liked to see his name in print, and he never shrank from publicity, good or bad, turning all to advantage. However, his recourse to the press was generally part of his current crusade, and publicity was simply an aspect of strategy. His ferocity and bluntness, his willingness to charge his enemies frontally, and his witty sallies made good copy. While not exactly cultivating the gentlemen of the press, he would dash off a quick note to columnists such as Arthur Caylor or Herb Caen and hope for an assist the next morning. Snodgrass' press sallies outraged the more conservative members of bar and academia. They also made him many enemies and caused most of his friends to conclude that Dave Snodgrass' worst foe was Dave Snodgrass. In retrospect, while a bit of distaste for his excesses lingers, it is apparent that he used publicity with enormous effectiveness. Indeed, it was most often his success that brought opprobrium. There remain those who are convinced that the Snodgrass campaign against compulsory retirement, in press, magazines, and on the after-dinner circuit, was merely a means to boom Hastings' uniqueness in having the 65 Club. In fact, Snodgrass had become convinced of the wrongness and wastefulness of compulsory retirement, and the number 65 writ large in industry and government was just one more Goliath that David meant to smite.

The personal crusades of Snodgrass were newsworthy and they remain fascinating, but they were not the stuff of which history is made save when they were fought in defense of Hastings. As he aspired to strengthen the College, build it a permanent home, and advance its reputation among law schools, so Snodgrass feared that there were persons in positions of power hostile to the College and to him personally. Perhaps 
there was a touch of paranoia in his fear, but that he and Hastings had enemies is not in question. Unfortunately, because of his fierceness, those who might merely have been Snodgrass' enemies soon became Hastings' enemies. He was incapable of distinguishing between his personal foes and institutional foes. Unlike Simmons, Snodgrass' personality was always caught up in battle, his image continually confused with that of the College. For Snodgrass, criticism constituted an attack and an affront, and it did not matter at whom or at what the attack was aimed, the defense was necessarily his.

He inspired loyalty as he stood on the ramparts. The Directors never failed to support him when battle royal was joined, though they tried manfully to quieten him down as he moved into position. ${ }^{12}$ He was fortunate in having a Board that underwent less change than at any other time in Hastings' history. During the 23 years that he directed the College's fortunes, there were only six new Directors. Two were appointed at the outset of his regular tenure in 1941: E. Clinton La Montagne (a Hastings descendant) and Eugene M. Prince. In 1946, Edgar T. Zook took the place of his deceased father-inlaw and law partner, Charles William Slack, and he was a worthy successor to Slack's devoted affection for Hastings. Justice A. Frank Bray, '10, took Maurice E. Harrison's place in 1951 - and still serves. Late in Snodgrass' tenure, Judge Daniel R. Shoemaker, '28, and Leonard A. Worthington, '32 (vice William Bradford Bosley) were appointed in 1959, and both are still Directors.

Throughout the most perilous struggles of dean and College, the Board was led by Bosley and Sidney M. Ehrman, with Chief Justice Phil S. Gibson playing a low-key but steadying role. Bosley succeeded Charles William Slack as vice-president on the latter's death, December 20, 1945. The death of Slack was deeply felt. Though almost 88 , his intellect was undimmed and his vigor undiminished when he presided over his last Board meeting just 10 days before his death. He stood for high academic standards, he was committed to the 
College's responsibility to serve the profession and the community, and he was a staunch defender of Hastings' integrity and independence. He had been the first dean of the type that Snodgrass personified. It was appropriate that when Slack died, having made his last contribution in support of the dean during the grim days of the War, the College was in the hands of a man who, though of a different epoch and opposite personality, represented Slack's aspirations for Hastings. Bosley proved worthy of Slack's presidial mantle, though he was more hot-tempered and testy. Bosley, Ehrman, and Gibson, along with Eugene Prince, who became influential especially in representing the College to the profession, admired Snodgrass. He merited and won their allegiance in the struggles to come.

The two other pillars of Snodgrass' support were his faculty and the College's alumni in positions of power. Snodgrass held his faculty with him in the face of adversity. The part-time practitioners who still undertook a large part of the College's instruction were loyal to a man, and carried weight with bar and capitol. The 65ers, many of them former deans of eminent law schools, would not suffer any derogation of an institution to which they lent their name and talents. With the $\mathrm{ABA}$ and the AALS - on the national stage - these men were veritable powers. Except for one important figure in the Alumni Association, the president who called for Snodgrass' resignation at the time of the Great Failure Crisis of 1950, the alumni remained solidly behind dean and College. Above all, the state legislature contained Hastings alumni ready to take up cudgels almost on demand for their old school: State Senator Gerald O'Gara, '26, and Assemblyman Gordon A. Fleury, '39, never failed to act when called into righteous battle, and the same might be said for a half-dozen other legislators who were only less prominent, not less loyal.

The two great struggles were with the California state Bar Examiners and with the University of California. The former was a war in which Snodgrass was as 
much a champion of others as a defender of his own interests. The latter struggle saw issue joined touching the very survival of the College, and while the din of arms was muted-unlike the war with the Bar Examiners which was fought out in public-the cost of defeat would have been unbearably high.

While California had required a written bar examination of all candidates since 1920, it was not among the 42 states which by 1949 were complying substantially with the ABA's standards for legal education for admission to the bar. California did not require two years of formal prelegal training for candidates for the bar examination over 25 years of age, and it still permitted law-office, private-study, and correspondence-course preparation for the bar examination without any other form of legal education. Indeed, its requirements for admission to the bar were lower than those of every other state save Arkansas and Georgia, and that almost three decades after the ABA's brave start on higher standards for professional preparation. The formal educational requirements for chiropodists, barbers, and even manicurists in California were higher than those for attorneys. Of course, this horror story took no account of the actual situation: Between 1932 and 1948, 95 percent of the 6531 who took the California bar examination had prepared in a law school, only 3 percent by correspondence course, and 2 percent in a law office or by private study.

California relied on a tough bar examination to banish incompetence in the profession. The examination lasted three days and was set on 20 subjects. The questions originated with law professors outside California, were thoroughly reviewed and analyzed by the Examiners and examination-readers before the examination, and were then assessed by California law professors after the examination. The readers' work was subject to appraisal by a panel. The candidates' anonymity was preserved, and no prejudice could come 
to them. Grading was fair, but strict. Between 1934 and 1949 , only 55 percent of those taking the examination passed. No more than 62.6 percent had passed (fall 1948 ), and the pass-rate had dropped as low as 34.3 percent (fall 1943). But the California Committee of Bar Examiners was likened to a football team "holding defensively on the one-yard line" against a multitude of poorly-trained postulants to the profession of attorney. ${ }^{13}$

In 1949 there were 16 law schools in California, one of them (UCLA) just starting in the fall of that year. Seven of the schools were ABA-approved, that is, they met the minimal requirements that had remained substantially the same since the Root Committee's reform in 1921: Boalt, Stanford, USC, Hastings, Santa Clara, Loyola (Los Angeles), and the University of San Francisco. ${ }^{14}$ They had enjoyed uniform success on the bar examination given by the State Bar's Committee since it had undertaken examination in 1927, succeeding the supreme court-appointed examiners. The other eight schools in existence by 1949 that presented candidates for the examination had had a mixed to abominable record on the examination. Admission to the bar was governed by Business and Professions Code sects. 6060-6068 (1939), which besides making provision for the bar examination established three paths to bar eligibility: by a law school "accredited" by the Bar Examiners; by a law school not so accredited; and by study in a law office, by correspondence course, or privately. In 1937, the State Bar had adopted the Bar Examiners' "accreditation rule" that was aimed at strengthening the good schools, improving the better of the poor schools, and eliminating the worst schools. The rule was not really an accreditation rule because it did not close off admission to an applicant who had not graduated from an accredited school; it merely made it more difficult and time-consuming for him to gain admission. The advantage derived by a student in an accredited school (besides a better education and a better chance on the 
examination) was that upon graduation after three years of full-time or four years of part-time schooling, he was eligible to take the examination. If a candidate had merely "diligently and in good faith studied law for at least four years"15_in an unaccredited school, law office, correspondence course, or privately-he was eligible for the examination upon proof of study and provided he had taken at the end of the first year's study a mini-bar examination of indifferent strictness. If the student had done his first-year work in an accredited school and subsequently did not graduate, he was still eligible to take the examination after his fourth year of study - the situation in which a number of the 47 of the Great Failure Crisis of 1950 found themselves.

An "accredited" law school was one which maintained, over three consecutive years, a certain cumulative average success rate on the bar examination taken for the first time by its students, whether they had graduated or not. In 1937, the required success rate was 30 percent, and it had been increased progressively to 60 percent in 1949. If a school failed to maintain the required success rate over the three preceding years, it lost its accredited status; henceforth its students would have to take the first-year mini-bar examination and would not be eligible to take the bar examination until they had completed four years of study (whether full time or part time made no difference). As soon as a school managed to climb back over the required success-rate line, it was once again accredited. Some California schools had drifted in and out of accreditation in this way.

By 1949 there was general dissatisfaction with the standards for admission in California, shared by the profession and by most of the law schools in the state. The reasons for the dissatisfaction varied considerably. Some practitioners feared that the profession was reaching saturation; law schools packed to overflowing with GIs seemed to give point to their apprehension. Tougher standards seemed the way to protect the inter- 
ests of those already admitted, although understandably the rhetoric used was that the public must be protected from incompetent lawyers. Many practitioners were seriously concerned that the bar examination defensive action on the one-yard line was already pushed back past the goal posts, that too many insufficiently learned lawyers were being let through. Practitioners and academics alike thought California's low admissions standards brought California lawyers into obloquy elsewhere in the country. The law schools were virtually uniformly dissatisfied with one aspect of the current situation: with the exception of only one school, they were against the accreditation rule. The dean of one of the strongest schools, in no danger of falling into unaccredited status, summed up the objections: The rule had not eliminated the weakest schools; it was based upon an arbitrary standard, subject to unpredictable variations especially perilous to small schools; it reflected not a school's merits, but whom the school had accepted and whom it failed; it was inequitable, since it charged against a school the failures on the bar examination even of those the school had not graduated; it induced "rat-race" competition among schools for a success measured solely by bar examination results, to which everything else was sacrificed-sometimes students, perhaps even the dean, always the curriculum. ${ }^{\mathbf{1 6}}$ The closer a school was to the dreaded "60 percent" stipulated success-rate, the stronger became the dean's objections to the rule.

The Bar Examiners' and the State Bar Governors' dissatisfaction with California's standards of admission and education led in 1947 to a bold plan to have an ad hoc board of outside experts survey the state of the subject. The board chosen comprised Joseph A. McClain, Jr., a leading practitioner in St. Louis with academic experience, Thomas F. McDonald, also of the St. Louis bar, and Sidney Post Simpson, a New York practitioner and professor at NYU with a decade of teaching at Harvard in the 1930s. Their credentials 
were impeccable and their disinterestedness beyond reproach. They were also thorough-Simpson won the sobriquet (which he sported with great pride) of "Sidney Pest" for the whirlwind force of his fine-toothed-comb investigative forays into California law schools. The investigation took a year of intensive effort, and the report was given to the State Bar in the fall of 1949 and released in published form in January 1950. The report, over 300 pages with 35 statistical charts, was a comprehensive general overview of California legal education and bar admission, and a detailed study of each law school in the state. ${ }^{17}$ The survey board made a series of recommendations that were specific and courageous, since there was considerable goring of sacred cows.

The report quietened some apprehensions and quickened others. It demonstrated that California was in no longterm danger of professional saturation: of the 10 most populous states, six had more lawyers per 100,000 than California, none of these states was growing at the rate California was, and in fact, since 1936 the proportion of lawyers per 100,000 had been in steady decline with only some indication of levelling off beginning about 1945. Neither was the picture of legal education as dismal as was popularly assumed: the seven ABAapproved schools were doing a good job, two unapproved schools (San Francisco Law School and Golden Gate) were comparable in terms of success with the lower ranking of the approved schools, and three of the six weakest schools at least had potential for adequate standards. However, the report was gloomy about the immediate prospects for beginning attorneys, noting the prediction of the U.S. Bureau of Labor Statistics of overcrowding in the next few years. It also asserted that California had too many law schools, badly distributed; that there were inadequate facilities for legal education in southern California, even taking into account UCLA's development, especially in the San Diego area; 


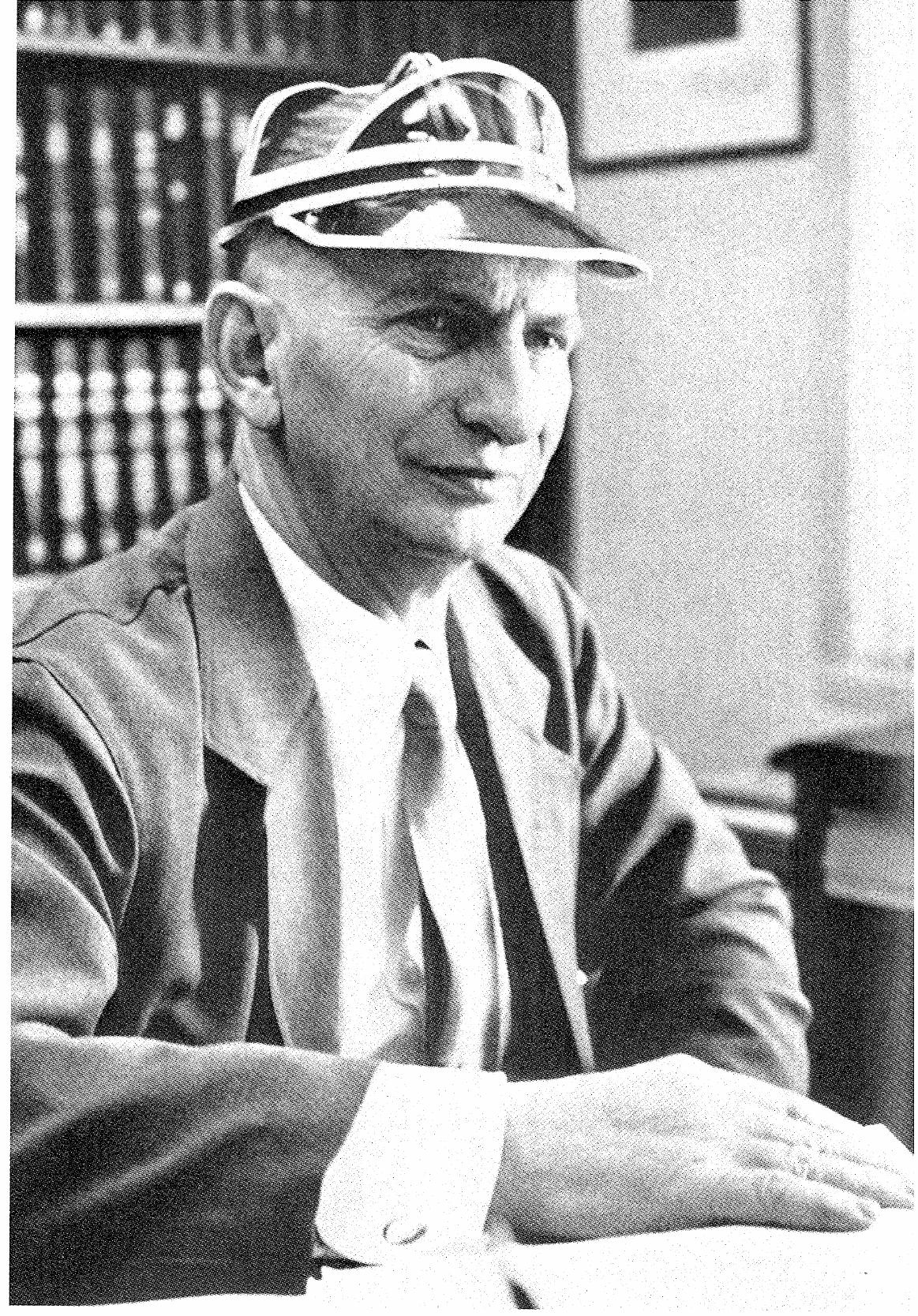

David Ellington Snodgrass 


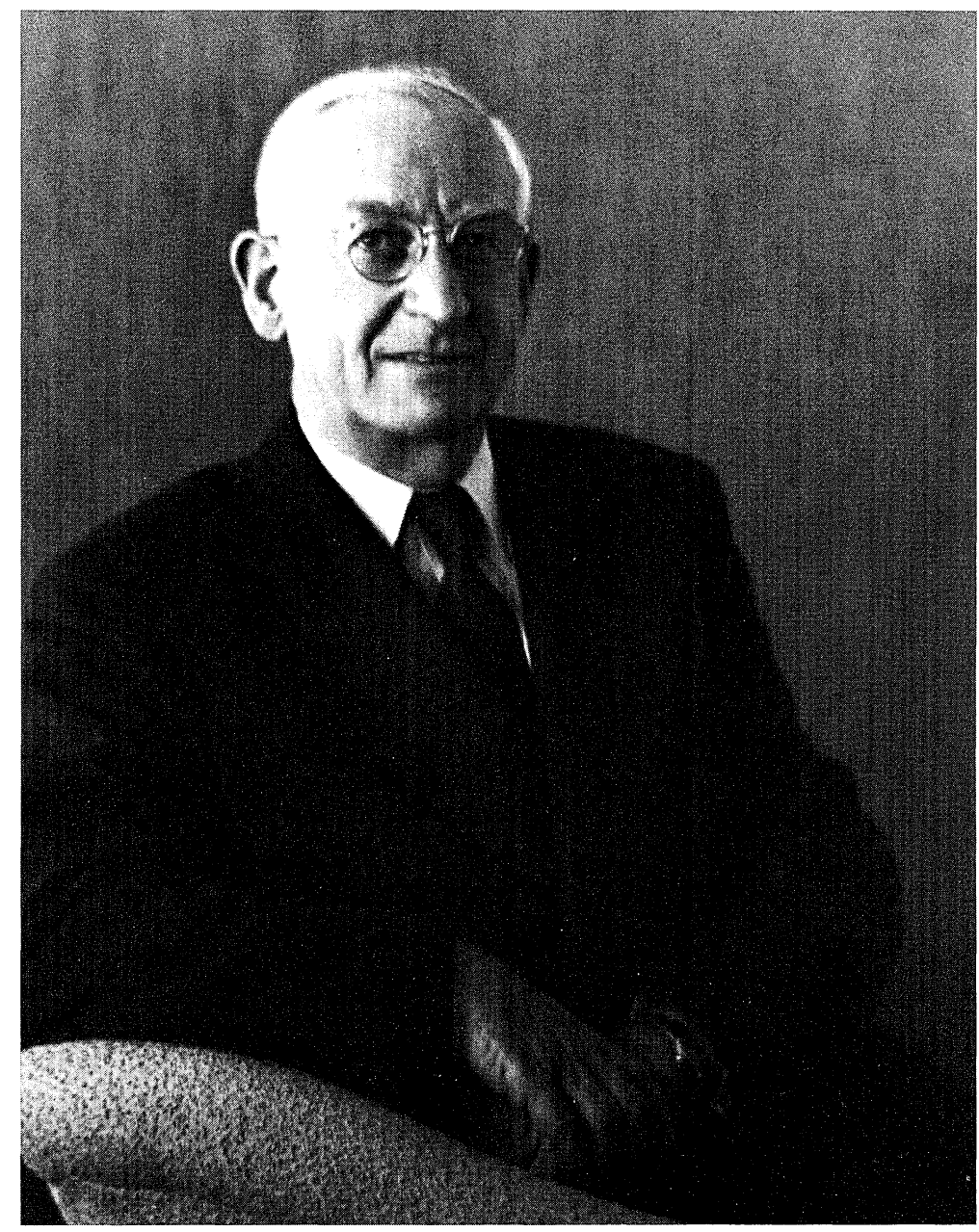

Robert Gordon Sproul

To my friend, Mavid E. Snodgrass in apporeciation of hie costributions to legal education, and expecially to the integration of Stastinge College of the hew with the Univeristy of Effomia Teent Rspoul. 
and that Sacramento was in desperate need of better educational opportunities. It castigated the University of California for not fulfilling its responsibilities for providing more low-cost legal education, especially in areas where facilities were inadequate. The report made clear that California had no excuse for not requiring every candidate for admission to the bar to have had at least two years of college; with eight state colleges and 55 junior colleges well-distributed over the state, educational opportunity was provided in abundance. What was most desperately needed, argued the report, was adequate, even generous funding of legal education in California directed at better pay to attract better faculty. Yet the clearest message was that the present system of admission to the bar was in need of wholesale reform. Here, apprehensions were more than quickened; they were inflamed.

The survey board called for abolition of the Bar Examiners' present accreditation rule, suggesting that there should be a new accreditation rule by which: 1. all schools presently ABA-approved would be accredited by the Examiners, 2. five of the unapproved schools would be given reasonable time to come up to essentially ABA standards or else achieve accreditation by merging with an ABA-approved school, and 3. the three weakest schools would not be accredited at all. In essence, the proposed rule would require graduation from an ABA-approved school or at least one closely approaching ABA standards. The survey board also invited the supreme court to reacquire control over bar admission quality, albeit by working through the existing State Bar machinery. The minimal statutory provisions would remain, but higher standards would be exacted by virtue of the court's power to determine the qualifications of those who were technically its officers and privileged to plead before it. There was authority for this in a case decided some years before. ${ }^{18}$ Though the survey board rightly feared that higher standạrds would 
be stubbornly resisted in the legislature, it was overly sanguine in expecting the court to do what the legislature would not.

In focussing on the accreditation rule, the report was roundly cheered by the law schools. But the law schools were not universally happy with the recommended new rule that approached ABA standards. Moreover, the report suggested a number of mergers of law schools to bring the weakest under the control of the strongest. These suggestions were the gorings that provoked the loudest shrieks. The University of California did not fancy taking over Balboa in San Diego, and it was desirous neither of absorbing McGeorge in Sacramento nor of seeing Hastings do so. The recommendation that Southwestern in Los Angeles merge with USC or else become both a full-time and part-time metropolitan school under the University of California pleased no one. The amalgamation of San Francisco Law School and Golden Gate with Hastings-by which the two former would become part-time divisions of the latter-was condemned by all three as a shotgun marriage not in the interests of any of them. All the law schools were at least agreed that legal education in California needed more money, and that the organized bar should see that it got it, provided always, of course, that the individual school's interests were not adversely affected.

The Bar Examiners rejected virtually every recommendation that affected them, particularly the idea that the supreme court assume responsibility for control of admissions standards. They took pains to assure everyone that they were open-minded on the subject of accreditation, but that until "a rule is suggested which in the judgement of the Committee [of Bar Examiners] is workable and better than the present rule, the present rule should be adhered to." ${ }^{19}$ In their report dated June 30, 1950, the Examiners promised full discussion of accreditation on the basis of questionnaires sent to the law schools. Within 10 days, the law schools had put enough 
pressure on the Examiners that they decided to call an open meeting with all interested parties to take place July 21 .

Before the open meeting all parties, including the law schools, had copies of the answers to the questionnaire, and of a number of comments and proposals that had been submitted to the Examiners. ${ }^{20}$ Only Pacific Coast (slated for oblivion by the survey report) favored the present rule; the rest of the schools were against it. Three schools, Loyola, Balboa, and UCLA, were unqualifiedly in favor of the survey board's recommended accreditation rule. Stanford wanted a tougher rule than the board's: no law schools accredited that were not ABA-approved, and these to maintain an acceptable pass-rate on the bar examination or their students would have to take a first-year mini-bar examination. Of five alternative plans suggested by the Examiners' questionnaire, two were combined in the replies of a majority of the schools as constituting the best solution to the accreditation problem: ABA approval would be automatic accreditation, and other schools would be accredited if they attained a watered-down ABA standard. The dilution of the standard would be in lowered library requirements, no requirement for full-time teachers, and a higher proportion of special students than was allowed for in ABA standards. This was the position of Hastings, USF, USC, Boalt, and Santa Clara, and with variations that of San Francisco Law School, Golden Gate, Southwestern, and (reluctantly) Lincoln.

Each position had its champion. Eustace Cullinan, a San Francisco attorney who had been a Bar Examiner in 1937, stalwartly defended the rule he had helped fashion. His basic proposition was that it had strengthened the good schools, improved the better of the poor schools, and eliminated the worst schools. Perhaps the middle proposition was sound-the rule had put salutary pressure on borderline schools to improve ${ }^{21}$ It had not eliminated bad schools, for the six which disappeared in the 1930s were victims of the Depression. The 
good schools had strengthened themselves because they were committed to educational improvement as a matter of principle and pride. Undoubtedly, Cullinan's position was favored by a majority of Bar Examiners in 1950, who wanted no change, notably Eugene Glenn of San Diego and three Los Angeles members.

The champion of the survey board's proposed rule and therefore of the three southern schools that opted for it was Homer D. Crotty. ${ }^{22}$ Crotty, a senior partner in the large Los Angeles firm of Gibson, Dunn, and Crutcher was a brilliant man, successful lawyer, genuinely learned, Boalt- and Harvard-trained, and a Brahmin by instinct, breeding, and experience. He had a national reputation through his activeness in the $\mathrm{ABA}$, had been chairman of the California Examiners, and was about to become president of the California Bar. He had played a role in establishing the survey board and long advocated the ABA standards for accreditation. However, on the eve of the July 1950 meeting, in seeking what he hoped would be an acceptable compromise, he proposed a new rule that combined the best of the survey board's recommendation and the worst of the present rule: All ABA-approved schools would be accredited, and all other accredited schools would have to adhere rigidly to ABA standards; the California Examiners would police the adherence of both the ABAapproved schools and the other schools, rather than rely on the imperfect review procedures of the ABA. So far, so good. But a graduate from a school not so accredited, or an office-trained, private-study, or correspondencecourse student, would still be eligible to take the bar examination after studying four years and passing mini-bar examinations at the end of the first and second years of study. Standards for the better law schools would be uniformly higher, but the backdoor to the bar represented by grossly substandard schools and by no formal schooling at all would remain open.

The champion of those schools which favored the combined alternatives of outright accreditation of 
ABA-approved schools and accreditation of schools not quite meeting full ABA standards was David Ellington Snodgrass. His position was hardly an advance over Crotty's, for though schools accredited by watereddown ABA criteria might be better than schools not accredited under the present rule, they would still be second-rate. However, there would be no lower road to the bar than such schools-which was an improvement over Crotty's compromise. The merit of this proposition was that the pass-rate peril would be abolished, marginal schools would be preserved but required to meet minimal criteria of academic soundness, and the strictly exploitative schools without standards would be eliminated.

Snodgrass was self-proclaimed champion of what he called the "democratic law schools." Crotty was the enemy par excellence. Besides a certain measure of temperamental incompatibility between them, Snodgrass detested Crotty's Brahminism and Crotty loathed Snodgrass' public combativeness. But was there a substantial difference in their positions on the issue of accreditation? On balance, both positions fell short of what the survey board recommended; neither was much of an improvement over the present rule save in getting rid of the obnoxious pass-rate threat, and neither would contribute much to improving legal education in California. But there was one essential difference between the two proposals. Crotty's plan would immediately force the eight non-ABA approved law schools to become four-year schools because of their wholly part-time faculties or inadequate libraries. Perhaps two, or as many as four of these might be able to improve themselves to ABA standards. Reasonably, those that did not and had to operate on a four-year basis would be so disadvantaged in attracting students that they would fail. Snodgrass' plan would remove that impediment from six of these eight. That was a difference substantial enough to polarize the two plans and their two champions. 
Dean Snodgrass came by his mantle of champion honestly. Of the ABA-approved schools, his remained the most democratic and least elitist, with the longest tradition of making a legal education available to the less prosperous and to those whose paper record indicated questionable potential for success. With USF and Santa Clara, Hastings stood in greatest threat of the 60 percent pass-rate stigma; this was not, in 1950, a matter of merely academic concern to the dean of Hastings. He had a solid reputation for helping veterans to an education, having sponsored the 1946 act allowing men whose legal education had been interrupted by military service to take the bar examination even though they had completed only two years of study in an accredited law school. In 1950, that was again a hot issue, the same legislation being proposed for Korea veterans, and once again being vehemently opposed by the State Bar. ${ }^{23}$ In 1944, Snodgrass, with the backing of the Hastings Board and especially the good offices of Chief Justice Gibson, had made a strong representation to the Examiners against raising the accreditation pass-rate percentage from 45 (set in 1942) to 50. That the increase did not take place until 1947 owed much to Snodgrass' intervention. In 1948 he had been the most forthright of all the deans in condemning the current accreditation rule. Explaining to the survey board why the College did not offer electives in new subjects such as Labor Law and Public Utilities, Snodgrass said:

The relation between the curriculum and methods of the Law School and the present California bar examinations is automatic. Instruction can be given in only those courses on which graduates of the school are likely to be examined by the bar examiners. ${ }^{24}$

What recommended Snodgrass most to his fellow deans of like mind was his combative fierceness and his unflagging enthusiasm for a fight. Deans Edwin J. Owens of Santa Clara, Edward A. Hogan, Jr., of USF, and Paul S. Jordan of Golden Gate were corresponded with, persuaded to fall into line, and urged to maintain 
a united front by Snodgrass. Even Prosser, sharing honestly in Snodgrass' dislike for the accreditation rule and on substantially the same grounds, found that he could but follow. Moreover, in Kenneth G. McGilvray, '33, of Sacramento, Snodgrass had an old student and staunch ally on the Examiners Committee itself, and in Eugene Prince, Director, a powerful figure on the Bar's Board of Governors. To cap all, Snodgrass enjoyed a legislative advantage, by virtue of Hastings alumni and friends with seats in senate and assembly, such as no other dean possessed. No one doubted that sooner or later, the battle would see a new front open in Sacramento.

It is hard to see what the Bar Examiners hoped to do by the open meeting in San Francisco on July 21, 1950. If they meant to witness their open-mindedness, the majority had already made it clear that they were unwilling to accept any change. If they thought that the opposition to the present rule would talk itself out, they underrated the seriousness of the outcry against the rule and the vehement commitment of its opponents. Perhaps they hoped that David Ellington Snodgrass would cause such a commotion that the opposition would go some way towards discrediting itself through its mouthpiece. It was common knowledge that 47 seniors had been failed at Hastings and that some of them would attend the meeting to demand justice. There would be present plenty of Snodgrass' opponents, including Homer Crotty, Eustace Cullinan, and Herbert W. Clark, a San Francisco attorney who was chairman of the ABA's Section of Legal Education and Admissions to the Bar. Later, Registrar Sammis voiced his personal conviction that Cullinan and Clark knew beforehand of a vituperative attack that the president of the Hastings Alumni Association meant to launch against Snodgrass at the meeting. The dean of Hastings could not get through the meeting unscathed. If such was the expectation of the Examiners, it was confounded by Snodgrass' absence; whether fortuitously or deliberately, he was away from San Francisco on Friday, July 21. Sam- 
mis, Director Prince, and Professor William G. Hale, former dean of USC, were Hastings' representatives.

The meeting proved to be a donnybrook. At the outset, it had to be moved to a larger room than the one planned because of the concourse of people, including a great many Hastings seniors. The Examiners favoring the present rule alone spoke in initiating the discussion, and they made a poor presentation. When the call went out for an indication of those who wished to speak for and against the rule, only six responded. The first to speak was Hale, who castigated the rule because of the unreliability of the pass-rate percentage growing from the wide fluctuations in bar examination results from year to year. Prince called Hale's speech "one of the best bits of advocacy I have ever heard." 25 Those speaking in favor of Crotty's proposal, including Crotty himself, were not very effectual. The apparent defection of Dean Shelden Elliott of USC from the Snodgrass camp to Crotty's proposal was no boon to Crotty-Elliott would not accept the first- and second-year mini-bar examinations proposed for students in unaccredited schools, and he made clear that he was really more against the pass-rate requirement than for Crotty's rule. The dean of USC was obviously very confused. Dean Carl Spaeth of Stanford was far too elitist in his approach, holding out for a higher standard than even the Examiners could accept or the present rule demanded; his more-royalist-than-the-king stance gave no comfort to Crotty's compromise proposal, and Spaeth ended up substantially in Cullinan's camp, arguing for no change. Prosser of Boalt and Owens of Santa Clara were absent, and it fell to Hogan of USF to put forward the position of the allies, which he did very effectively. As the debate progressed-rather aimlessly-it became apparent that without Snodgrass present those who had come to shoot at him did not quite know what to do with their guns. That did not prevent one of them from shooting wildly anyway. Arthur W. Brouillet, '11, an implacable foe of Snodgrass and president of the Hast- 
ings Alumni Association, rose to make a choleric personal attack on Snodgrass. His eye was on the legislators present, his heart was with "Fuzzy" Taylor, whom he obviously considered the last great dean of Hastings, and his spleen was vented on behalf of the 47 failed students. He accused Snodgrass of inattention to his job (a strange charge coming from an admirer of Dean Taylor), and of spending more time attacking the Bar Examiners and giving press interviews than in working to improve the school's record on the examination. The failure of the 47 he called an act of "academic blackmail." Hale and Sammis replied, and Brouillet was badly mauled by their defense of Snodgrass and the presentation of the facts in the case of the 47. In fact, Brouillet had shot only himself. Imputations he directed at Hale as dean of USC only made the wound worse. After Brouillet's wild sortie, the meeting evaporated. The first battle had gone to the presence that was absent, the absence that was present, David Ellington Snodgrass.

The rest of the battles were not so spectacular, neither were they so significant. Snodgrass and his allies, whatever the merits or demerits of their position, won the initiative on July 21, 1950, and they never lost it. The Bar Examiners and the State Bar were forced to fight a rearguard action that in the next three years barely prevented a continuous retreat from becoming an utter rout. The first concession came in November 1950 when the 60 percent pass-rate requirement was amended to allow for a school that had fallen below it to remain accredited pending a complete investigation of its academic soundness by the Examiners. This had been suggested before the open meeting by one of the Examiners; it became an urgent matter when Golden Gate, San Francisco Law School, and worst of all, Santa Clara, fell below 60 percent in the October 1950 examination. In January 1951, the Examiners recommended that accreditation be frozen until January 1, 1954, and they proposed to the State Bar that it sponsor legislation 
abolishing accreditation and requiring a candidate for admission to complete at least two years of prelegal college study, graduate from a law school requiring classroom attendance, and pass a mini-bar examination. The State Bar accepted the proposal, but deleted the last provision. The Bar's bills in the senate and the assembly, in competition with pending bills promoted by the opponents of the accreditation rule, were chewed to pieces in committee, and the Bar Governors found themselves in a hopeless situation unless they accepted the strongest bill of their opponents. This was Senator Gerald O'Gara's bill, SB 386, which might as well have been called Snodgrass' bill. SB 386 would lower the 60 percent pass-rate to 50 percent, no longer charge students who had not been graduated against the college that had failed them, and give a two-year grace period to schools that had fallen below the 50 percent pass-rate and were threatened with disaccreditation. The Bar joined forces with O'Gara, who accepted the Bar's provision requiring graduation from a law school demanding classroom attendance. The O'Gara bill passed the senate, but was amended in the assembly to eliminate the graduation requirement; in this form it passed both houses. Only the governor's veto prevented California from having a weaker admissions standard than it had before the accreditation rule came under attack.

The handwriting was on the wall; if the Bar did not change the accreditation rule, the legislature would. After much consultation and fervent breast-beating by the Examiners (the membership of which had become more favorable to the position of Snodgrass and his allies), a new rule went into effect in 1952. It was just in the nick of time. The October 1951 bar examination results were a disaster, producing the lowest percentage of passing candidates since the war. Though the Examiners explained it as a return to "normal," the best of the GIs having passed through law school, the senate judiciary committee (of which O'Gara was a member) took up the cause of the failed candidates. After a thor- 
ough investigation, including public hearings, the senate committee requested the state supreme court to review the matter and called for the Bar Examiners to be made responsible henceforth only to the supreme court. $^{26}$

The Bar's new accreditation rule abolished the pass-rate requirement. It approached the ABA standard in making the primary test for accreditation by the California Bar Examiners the maintenance of a sound educational policy by a school which admitted students with two years of prelegal college-level work. However, the school was allowed a higher percentage of special students than the ABA stipulated for approval, the library of an accredited school was held to a standard inferior to that of the ABA, and the school was not required to have three full-time professors. In short, the new rule was substantially that suggested by the schools championed by Snodgrass in 1950. The only concession to Crotty's proposal was that the Examiners would police quality and be responsible for the accrediting investigation-there was no choice, since a school with such standards could not obtain ABA approval.

The accreditation matter settled, the State Bar felt strong enough to tackle the legislature for amendment of the code provisions: that by 1960 graduation from an accredited law school alone would provide admission eligibility; that in the meantime all candidates for the bar would be required to have two years of college work or its equivalent; and that by 1954 eligibility by law office, correspondence course, and private study would be abolished. The Bar's bill was mangled in the capitol. Two years of college work as a requisite survived, but graduation from an accredited law school as the sole means to eligibility failed, and only private study was damned. What the Bar Examiners hailed rather pathetically in 1953 as "the first step in raising the standards of prelegal and legal education for admission to practice law that has been taken in California since 1937" 27 was more a little sideways shuffle than a full pace. The State 
Bar had only itself to blame. Its intransigent adherence to an accreditation rule that was both inadequate and inequitable raised a furor in the legislature that did not abate and which poisoned the chance for rational reform. Had the Bar Examiners in 1950 taken up the survey board's recommendations for accreditation, there would have been much less opposition to change, less intervention by the legislature, and some substantial reform in the standards of legal education and admission in California. In the event, the opportunity was lost. The new code provisions of 1953, hardly an improvement over those in effect since 1939, still stand and still determine the educational requirements for bar eligibility. That is the main reason why today, of the 65 law schools in this country not approved by the $\mathrm{ABA}$ or accepted as members of the AALS, 48 are in California.

No one had smarted more under Snodgrass' attack on the old accreditation rule than Eugene Glenn of San Diego, LL.B. Stanford, member of the Committee of Bar Examiners and its vice-chairman, 1950-51. Glenn had been roundly scored by Snodgrass in the press, and Prosser concluded that Glenn manifested an attitude towards Snodgrass "tending toward vindictiveness." 28 In the heat of the battle in 1950, Glenn gave a speech before the National Committee on State Bar Examiners calling upon the ABA to reinspect law schools of questionable standards, and instanced Hastings as an example. He charged particularly that Hastings students were so heavily engaged in outside employment that Hastings was really a part-time law school, and its students should be required to study for four years, per the ABA standards. The ABA took up the call, and an Oklahoma lawyer, John G. Hervey, who undertook a great many inspections for the $\mathrm{ABA}$, was ordered to inspect Hastings. Hervey arrived in early winter 1950 . He conferred first of all with Glenn, Herbert W. Clark (whom Sammis suspected had had foreknowledge of Brouillet's philippic at the open meeting in July), and Prof. James 
Brenner of Stanford-all three personal enemies of Snodgrass and ill-disposed towards Hastings. Hervey's inspection of the college was so slipshod and narrow in focus as to leave no other conclusion than that it was intended only to garner incriminating evidence. The inspector talked to no faculty except Snodgrass, Sammis, and two 65ers (these latter only briefly and by chance), visited no classes, and talked to no students. He then went around San Francisco law offices, to find out what he could about the employment of Hastings students. He did not make a return call on Snodgrass, but went home, drew up his report, and submitted it to the ABA's Section on Legal Education and Admissions to the Bar. $^{29}$ In February 1951, the Section found that Hastings failed to comply with the ABA standards for an approved school because it did not enforce the full time requirement, its library accommodations and classrooms were inadequate for the heavy enrollment (although the Section recognized that the new building would take care of this), it enjoyed such an extraordinary excess of income over expenditures as to savor of a commercial operation, and its educational policy was unsound in not providing for study breaks between classes, placing undue emphasis in the curriculum on bar examination subjects, and readmitting too many failed students. A new inspection was to take place in fall $1951 .^{30}$

Hastings rose up in arms. Director Eugene Prince threatened to defy the ABA if the College was dropped from approval. The refusal of the Section to give the dean a copy of Hervey's report (despite the fact that the report of the inspector in 1943, Russell N. Sullivan of the University of Illinois, had been supplied then), made it difficult to respond to the charges. After wheedling more details out of the chairman of the Section, the entire full-time faculty replied to the charges: Snodgrass, Sammis, Vice-Dean Edward A. Hogan, Jr.- - who had just come aboard after having been dean at USF - and six 65ers. ${ }^{31}$ Four of the faculty 
had been deans of other law schools (Cornell, Minnesota, USC, and USF), two were past presidents of the AALS, and one had participated in the establishment of the ABA's standards. They demolished the allegations. The results of a questionnaire circulated to the students indicated that about 60 percent of them were not regularly employed, and the remainder not so heavily engaged as to prevent them from devoting full time to their studies. The physical facilities charge was a make-weight and was easily dealt with. As for surplus revenue, the faculty pointed out that since it went to the College's program and benefit there was no commercial operation, and the school was in strict conformity with the ABA's strictures preventing profitmaking legal instruction. The school's educational policy was defended on the grounds that concentrated classroom work was preferable to a more languid program and gave as much time for study, that the school had no choice in the matter of course offerings because of the restrictiveness of the state bar examination, and that even before the inspection, the College had tightened up on readmission in particular and standards in general. Earlier, Snodgrass had pointed out to the Section that the survey board in 1949 had given a favorable report on Hastings and had concluded that it was "the keystone of legal education in Northern California so far as the mass of prospective students is concerned" and that with improvement "this school may well become one of the great metropolitan law schools of the United States." 32

The local press took up Hastings' fight. The 65ers, led by Everett Fraser, formerly dean at Minnesota, asserted the faculty's responsibility for student matters. Readmission was tightened further and effective steps were taken to cut back excessive outside work by students. Fraser and George G. Bogert went after Hervey and the $\mathrm{ABA}$ with a vigorous counterattack that was carried to the December 1951 meeting of the AALS. So effective was Fraser before the AALS's committee on 
relations with the ABA, that it appointed a subcommittee to remonstrate with the ABA. This signalled the effective end of the locally inspired counterattack against Snodgrass and Hastings carried out at the national level. Hastings did not lose its ABA approval.

With the opening of the new building in 1953, the April bar examination of that year was held in it, and the State Bar's lectures in the continuing education program it sponsored were given in the new classrooms. Snodgrass was even made an honorary member of the San Francisco Bar Association. The final accolade came from the president of the State Bar in his message of congratulations on the opening of 198 McAllister:

No message on Hastings would be complete without a bow in the direction of its inimitable Dean David E. Snodgrass. True, he and the State Bar-particularly its Bar Examiners-in the past have often failed to see eye-to-eye. Yet without his devotion to the college, his persistence and determination, I wonder whether the Hastings dream of a grand new home would have been realized for many years to come? Kudos to you, then, Dean "Dave" Snodgrass! 33

That was quite a compliment coming from a Stanford graduate, but he might have mentioned that if Snodgrass and the Bar had not always seen eye-to-eye, they were certainly eyeball-to-eyeball for a long time. "Dave" had the better stare.

Robert Gordon Sproul, as W.W. Campbell's provost at the time of the Reed affair in the 1920s, had formed an early and unfavorable opinion of Hastings. From 1930, when he became president of the University of California, to his retirement in June 1958, Sproul never felt impelled to change that opinion. His was not an active animus, merely a fundamental conviction that Hastings was not and never could be an institution to the measure of the University of California; that it was and must remain inferior to the Berkeley School of Jurisprudence. Hastings had no place in Sproul's ambitious scheme for the greatest state university in the 
country. Unless he could control it, he could not transform it-and Sproul was not sure Hastings was worth transforming into anything other than a night school, a glorified university extension program. He was too astute a politician not to realize how difficult it would be to get rid of Hastings entirely, protected as it was by statute and venerableness. Routinely, Sproul preferred to ignore Hastings, to keep it as far distant from himself, the Regents, and the rest of the University as he could. He was not averse to basking in its reflected glory; he added its GIs to the University's rolls to demonstrate how heavy were the pressures of numbers on the University, and how necessary, therefore, that the legislature respond more generously to enable the University to do its job. But he was quick to disown any authority over or responsibility for Hastings when it became involved in controversy. He was annoyed repeatedly by those who did not understand the nature of Hastings' autonomy, and he sometimes found it impossible to avoid involvement under such circumstances. When heavily pressed over some apparent outrage, Sproul was moved to contemplate how Hastings might be neutralized or even brought into the University fold and so effectively repressed. He was always somewhat at the mercy of his own troops, particularly the dean of Boalt, those who were embarrassed by Hastings and its prickly dean after 1940 .

Sproul was a thoroughgoing imperialist and a grand egotist. It was he who did indeed build the University of California into the greatest state university in this country; it fell to Clark Kerr to complete Sproul's work, articulate its philosophy in the notion of the "multiversity," and carry the whole one step further so that it became one of the two or three most eminent universities of any sort in the United States, and among the most renowned in the world. Sproul was a great imposing figure of a man, a superb speaker, with a booming voice that moved one of his aides to chide him for using the phone to call Sacramento when all he had to do was 
open the window. He administered as a caesar, his directions were imperial rescripts, his memoranda obelisks recording bold acts. He was justifiably loaded with honors, he took an active part in partisan politics-he nominated Earl Warren for President at the Republican National Convention in 1948-and he had the distinction of receiving an assembly concurrent resolution of the legislature in 1947 imploring him to resist blandishments from other universities and remain at the helm of the University. This was all very heady stuff. Sproul knew only one great reverse in his tenure: the loyalty oath crisis of the late 1940 s and early 1950 s, that both tarnished his reputation in academia and irreparably eroded his command of the Regents. Sproul never quite recovered either his former glory or his previous authority in governance over the University. ${ }^{34}$ That did not prevent him from trying, and he did not cease to rule as well as reign until he stood down amid panegyrics, becoming President Emeritus, and occupying his old office, in the building from which he had directed the University's fortunes since its construction in 1941, which was promptly named for him upon his retirement.

David Ellington Snodgrass was no less an imperialist and egotist; only his fief was smaller. The relationship existing for two decades between Sproul and Snodgrass was complex. Each respected the other's remarkable capacity for self-advertisement and selfaggrandisement. Each admired the other's courage and cunning. They met easily on the neutral ground of the Bohemian Club and enjoyed each other's company at the Bohemian Grove. Their duels never degenerated into a blood-feud: towards Mrs. Sproul, whose brother had been professionally close to Snodgrass, the dean always exhibited great gallantry, and Sproul's son (of the same name), briefly a student at Hastings upon leaving the Navy in 1946, remembers Snodgrass' kindness towards him. With Sproul's retirement, there crept into the combatants' correspondence, which before had 
been at least wary, and usually acrimonious, the affectionate tone of nostalgic souvenir of old warriors resting on the hilts of their swords, points downward.

So long as Orrin Kip McMurray was dean of Boalt, there was no internal pressure on Sproul to deal in any way with Hastings. That changed when Edwin D. Dickinson became dean in 1936. Dickinson's concern with Hastings' nonapproval by the ABA had moved Simmons and the Board to the changes necessary to gain that recognition. A month after Simmons' death in 1940, Dickinson wrote Sproul (obviously at Sproul's invitation) with respect to what policy the University should follow in the light of the imminent appointment of a new dean at Hastings. All that Dickinson would suggest was "care and discrimination" in the choice of a competent dean whose academic standards would be as high as Simmons' had been. Though Hastings was not "in step with modern developments in legal education," it did render a real service in training lawyers who could not afford Stanford or Boalt or did not meet their admissions level. He was against merging Hastings and Boalt, against moving Boalt to the City and Hastings, and against moving Hastings to the Westwood campus in Los Angeles. He concluded:

With mixed emotions and with some regret, I return to my conclusion as previously stated. Hastings College of the Law should carry on. The time may come later for a merger or transfer. It seems clear that this is not the time. ${ }^{35}$

Of course, the University had nothing to do with selecting the new dean, and it was in no position to say whether Hastings could or could not "carry on."

Relations between the University and Hastings worsened rapidly in the later 1940s, as the two imperial potentates clashed. Even Dickinson, who was fairly even-minded, was moved to write Sproul that the University should rid itself entirely of the "dubious and somewhat embarrassing relationship" with Hastings by taking it over. ${ }^{36}$ Sproul had been appalled to discover in 1945 that Hastings intended to open a branch in Sac- 
ramento which would, according to Regents' counsel, be "a branch of a department of the University of California." ${ }^{37}$ Hastings had not discussed the move with the University, and by the time the University reacted, Education Code sect. 20154 was already law: "All courses conducted by the college at Sacramento shall be deemed to be given at the site of the college [Hastings] in San Francisco." 38 Hastings did not open a Sacramento branch because the GI deluge kept Snodgrass and his administration too well occupied to divert attention elsewhere. But the survey board in 1949 picked up the notion in suggesting the arrangement between McGeorge and the University, either directly or through Hastings, and when the University entered into negotiations with McGeorge for University Extension to give law courses in Sacramento, Snodgrass reacted like a jilted suitor. The controversy was still echoing in the early 1960s when the Directors expressed their concern with the proposed law school at UG Davis. In 1947, University Extension, with the backing of Dickinson and Sproul, and in cooperation with the State Bar, moved to give law courses in San Francisco for continuing education of attorneys. Overtures of cooperation made to Snodgrass were rejected, and the dean let loose a counterattack in the press and through the San Francisco Bar Association, as well as directly upon Sproul, that raised a great furor. University Extension was not to be stopped, however, and in 1948 the first courses were given in San Francisco; they were an unqualified success. To Snodgrass, the courses were an invasion by the University of the "last refuge of Hastings College of the Law," and the product of a conspiracy between Boalt, University Extension, and the State Bar to set up a night school in law in the City. ${ }^{39}$ Dickinson left Boalt for Penn in 1948; Boalt's new dean, William L. Prosser, was made of sterner stuff. Convinced that Snodgrass was paranoid, Prosser argued that the time had come "when something must be done" about Snodgrass. ${ }^{40}$

Sproul had sought in the fall of 1947 to discuss the 
Extension matter at a joint meeting of Hastings Directors and University Regents. ${ }^{41}$ Clearly, though, amalgamation of Hastings and the University was in Sproul's and Dickinson's minds. The meeting came to nothing; Directors Bosley, Ehrman, Chickering, and Zook apparently would not deal with the bigger issue, and rightly insisted that the Extension affair was Snodgrass' business. The meeting was not really relevant to Sproul's grand strategy, which had occurred to him when Hastings had had to approach the state for its new building through the Regents and by the good offices of the University administration. At that time Sproul was not ready to take up the suggestion of Comptroller James H. Corley (an officer of the Regents) that now was the time "to take over the entire administration and complete jurisdiction of the college as well as the responsibility for the construction of the physical plant." 42 That was too much, too soon. Sproul's strategy was to stifle Hastings by kindness. The entire structure of budgeting and accounting required for state appropriation had become increasingly complex in the course of the 1940s. Hastings did not have the administrative staff to cope with the forms and the careful calculations demanded; even to obtain the statutory annual appropriation of $\$ 7000$, a formal presentation supported by documentation had to be made to the state department of finance. The University had a staff much practiced in the procedures, and Sproul offered the services of Corley and the finance staff of the University to assist Sammis in preparing the 1949-50 budget. In the next year, this assistance was expanded, and Corley undertook to submit the Hastings budget in person at the Sacramento budget session, acting for the College, not the Regents. In December 1949, as Sammis struggled manfully to lay out an entire preliminary budget in justification of a $\$ 7000$ appropriation that was due by right, Corley advised his assistants that their participation in Hastings' budgetmaking was a "matter of policy, not accommodation." 43 As Hastings became increasingly dependent 
upon the University for budgetary assistance, a general administrative dependency might evolve. Sproul believed that the day could not be far off when Hastings would gladly accept an "affiliation" tantamount to subordination.

There was a fatal flaw in Sproul's grand strategy. He meant to effect by administrative means what could only be worked at the highest policy level. The Regents were not a party to his scheme. Doubtless, he hoped that as the College's dependency increased, and Snodgrass reached the point of capitulation, he could present the Regents, and Snodgrass could present the Directors, with a fait accompli. With Maurice Harrison and Sidney Ehrman on the Regents, Sproul had to be circumspect; and as the loyalty oath controversy deepened, Sproul found himself increasingly on the opposite side on that issue from Harrison and Ehrman, who took a hard line in favoring the oath. Corley was technically an officer of the Regents (and remained so even after the 1949 reorganization that made him vice-president-business affairs), but his working relationship in finance was with the president, and he managed to play his part in the scheme without compromising his duty to the Regents. Jno. U. Calkins, Jr., the Regents' attorney, was told no more than he needed to know in the matter, and he accepted that Sproul sought to bring the University and Hastings together at a high level of consensus for affiliation. Sproul did not exact any conditions for helping Hastings, not because he did not want to, but because to have done so would have required Regental action and direct negotiation with Hastings' Board. This Sproul was not prepared to risk. The failure to exact conditions by formal agreement with the Hastings Board defeated the grand strategy. Snodgrass might be grateful, but he was not about to give anything away.

In fact, Snodgrass did very well by Sproul's kindness. He received a great deal of help when neither he nor Sammis could take time to prepare budget. And Snodgrass was never shy about asking for more. He 
badgered Corley for even greater assistance, and in 1951 Corley complained to Sproul of the thin line he had to walk:

I find myself in an embarrassing situation in trying to follow your instructions to work more closely with the Hastings administration and also, in this particular case [budget], to remain on the outside as far as the budget is concerned. ${ }^{44}$

All that Sproul could tell Corley was not to accept any responsibilities for Hastings, "custodial, protective, or otherwise," until the relationship of the College to the Regents had been reduced to formal terms, but to carry on with such assistance to Hastings as had been extended in the previous couple of years. ${ }^{45}$ Two years later, Corley was still trying to find out how far he should go. The issue then turned on whether Hastings had to accept filing cabinets of the type supplied to all University departments by the purchasing department, or could buy its own from the $\$ 1600$ gained by sale of its old furniture (Snodgrass had to battle to keep that money). ${ }^{46}$ Snodgrass wanted a better quality filing cabinet! The provocation might be risible, but the profound import of the dispute was not. While the Regents had title to 198 McAllister-by virtue of the act appropriating the money for its construction-the building's furnishings were the property of the Directors if they were purchased with the College's own funds, over which it could claim control by virtue of the 1878 act. In the event, Snodgrass got the file cabinets he wanted, with Hastings money, and Corley and Sproul decided not to press the matter to Regental level. Without a clear Regental policy, only Snodgrass could win.

With the help of Sproul's kindness, Snodgrass and Sammis soon learned the ropes of state financing. Moreover, Hastings began to acquire the extră administrative personnel necessary in a bigger and more complex operation. The acquisition of Dean Edward A. Hogan, Jr., from USF in February 1951 was the key development. Hogan became vice-dean with general responsibility for administration in curriculum and student 
matters. Besides providing new services the College had not enjoyed before (such as a regularly operated placement service), Hogan freed Sammis to undertake budgetary and finance operations almost full time. Instead of resulting in the creation of dependence upon the University, the University's help educated a newand independent-administrative machine at Hastings.

Below the august level of president and vicepresident, the University's troops champed at the bit. When Hastings was under fire from the ABA in 1951, Prosser wrote Sproul that the ABA's attack "seems to me to be one more indication that sooner or later the University will have to take over Hastings . .." and operate it as a "good part-time law school..." meeting ABA standards. ${ }^{47}$ Prosser's attitude towards Hastings (and its dean) was ambivalent. In the March 1949 issue of the alumni magazine, which featured the glorious imminent prospect of three University law schools, each in its own new building, Prosser had called for a healthy competition among the new Boalt, the new Hastings, and the truly new UCLA Law School. ${ }^{48} \mathrm{He}$ also argued that rivalry that would set them at cross purposes would be disastrous. Though he did not say so in the article, Prosser saw Hastings' role as being that of a night school. Since Hastings and the two City night schools refused to merge at the urging of the 1949 survey board, Prosser believed that Hastings should fill that need in the system.

While Hastings had no intention of becoming merely a night school, in 1951 it seriously considered adding a night-school program. A faculty committee (Fraser and Vold, 65ers, and Hogan) weighed the advantages and disadvantages, and concluded on academic grounds that the night school should not be tried. ${ }^{49}$ What moved the consideration was that in 1951 enrollments at Hastings began to drop alarmingly. From the high in fall enrollments of 915 in 1949, the decline was to 724 in 1950, 485 in 1951, and a low of 293 in 1952. The GI bulge was ending, and to com- 
pound the problem, the faculty's new high standards cut off marginal students already in the College and discouraged others from applying. Beginning in 1951, a graduating class was reduced to about 40 percent of its beginning size-an increase in the drop rate of some 20 percent over 1950, when 62 percent of that class graduated. Anticipating that the ABA would require three years of college for admission to an approved law school, Hastings required the same beginning in 1950 . This cut off at a blow an indeterminate but probably sizable portion of Hastings' constituency. The AALS interpreted the new standard to allow a student with two years of college to enter a four-year law school program; the ABA found this acceptable. Hastings, in common with a number of law schools faced with the famine after the feast, instituted the four-year program in 1951-52 to cater to students with only two years of college. The four-year program was never a success (it was discontinued in 1961) because it did not bring in enough students to make up the loss occasioned by higher admissions standards. The California junior colleges produced plenty of students in two years, but few of them were so sanguine as to believe they were ready for law school. In 1951, Hastings faced the grim prospect of much reduced income from the loss of student fees, the end of the extraordinarily profitable GI bonan$\mathrm{za}$, the necessity to consume its nest egg, and the need to resort once again to substantial state funding. The new building alone would require a level of maintenance that would have demanded extra funding even at the height of the GI deluge.

Sproul, in a confidential memo to Prosser dated February 6, 1952, reminded him of his remark a year earlier, that "sooner or later the University will have to take over Hastings," and concluded, "Do you believe that the time has come for us to move in, or should we continue to wait, at least until Bosley is gathered to his Fathers?"50 Allowing for much forced bravado (Sproul never told Prosser that the grand strategy was a bit more 
modest than "moving in"), it was a reasonable question in the light of Prosser's answer. Prosser reported that he had discussed Hastings' financial situation with Snodgrass, and that Snodgrass said the College was exploring state financing-financing independent of the University-but that he had been told in Sacramento that Hastings had no hope of getting state money except through the University. ${ }^{51}$ Snodgrass had admitted that the College would be in the red in the current year, and indicated he was very reluctant to consume the nest egg from the GI years. According to Prosser, Snodgrass told him that he had discussed with the Directors the possibility of "getting together with the University," and that while a majority of them favored it, Bosley and one or two of the older generation were violently against it, and the rest of the Board would not vote it over their opposition. Allowing for Prosser's wonted predilection for exaggeration, this was a startling admission even if it was only partially correct. Prosser's advice was to wait a year, when financial extremity would go far towards changing the Board's ideas.

The situation was parlous. Quite aside from the worsening financial predicament of Hastings, Sacramento had become accustomed to Jim Corley presenting the Hastings budget request; it was not unreasonable for the director of finance and the legislators to conceive of the Regents as the proper funnel for money to Hastings. So far had Sproul's grand strategy worked. If Hastings was not going to become dependent upon the University for the appropriation requisite to its continuation, it was going to have to assert its autonomy by acting directly on its own behalf with the finance department, and use every ounce of its political clout to persuade the legislature to support it. Snodgrass was equal to the task. When the assistant director of finance asked the dean's advice on law schools for his son, who had shown an interest in Hastings, Snodgrass' reply was most warm. ${ }^{52}$ When Clark Bradley, '31, was elected to the assembly in 1953, Snodgrass' letter of congratula- 
tion ended by urging him to support the College's future budget request. ${ }^{53}$ In 1954, the College made its appeal. Assemblyman Gordon A. Fleury, '39, and Senator Edwin J. Regan, '31, were joined by other legislators and ex-legislators-including Oliver Carter, '35, Arthur H. Connolly, Jr., '35, and Gerald O'Gara, '26and a number of prominent California lawyers to urge the legislature to save the College. The response was gratifying; $\$ 49,080$ was appropriated, and the department of finance, the legislative auditor, the governor, and the legislature went on record as favoring state support for Hastings in subsequent years. ${ }^{54}$ The Hastings appropriation appeared in the budget act as separate from that for the University of California, as in all previous years.

Only once more before Snodgrass' administration ended was "affiliation" or a closer relationship between Hastings and the University seriously broached. In the budget act of 1958, Hastings was entered as a lineitemed budget for the appropriation, and therefore its revenues made subject to being taken into the state treasury. The University's regular budget had always been (and is yet) exempt from line-itemization, that is, from division under categories of need. The budget was voted as a single lump sum, with its revenues exempted from payment into the treasury. The Regents were scared ${ }^{55}$ If Hastings was part of the University, then line-itemization of its budget threatened the University's exemption from the same practice. In September 1958, the Regents' committee on finance directed the new president, Clark Kerr, to arrive at a mutually satisfactory arrangement for "a closer integration and affiliation" of Hastings with the University, and to notify the department of finance that Hastings "is a part of the University of California and as such its budget should be administered in the same manner as other University budgets." ${ }^{56}$ Kerr sought to play a cool and steady game. He kept the Regents out of direct contact with Hastings. $\mathrm{He}$ strove to placate Snodgrass: Snodgrass alone, at 
Kerr's inaugural luncheon, was singled out for personal recognition from among the "University's" law professors (much to the wounded pride of the Boalt professoriate). Snodgrass disingenuously assured Kerr that he had made a personal contribution to the formulation of such an agreement, but that the matter was in the hands of the Board and its vice-president, William Bradford Bosley. Bosley would have joined the Communist Party before allowing Hastings to affiliate with the University of California. By November 17, 1958 (an English historian notes it was the four-hundredth anniversary of the accession of Elizabeth I), the last round of courtship to make the common-law marriage of Hastings and the University a legitimate union was dead. "Dear Clark," wrote Snodgrass, "Do you suppose that we'll get together by 1978, in time for the one-hundredth anniversary? With internecine regards, Dave." ${ }^{57}$ So far, the answer is no.

Neither was line-itemization for Hastings recinded-Hastings still appears that way in the budget act each year, though the University has not suffered by that. Indeed, line-itemization is the talisman for Hastings' autonomy.

What Sproul had not accomplished, Kerr could not really care about less. But the old warrior never gave up hope. In March 1961, Robert Gordon Sproul, president emeritus for almost three years, had dinner at the Bohemian Club with William L. Prosser, who would retire at Boalt three months later. They talked about the possibilities of the merger of Hastings and Boalt. Prosser was convinced that with Bosley having retired, the Hastings Board would be more friendly to the idea, and that Snodgrass would still be willing to back it. Sproul suggested that Prosser talk to Snodgrass, and that if the opportunity arose he would too, but that he was unwilling to take the initiative in view of his retired status. Prosser suggested that Sproul read Capt. Joshua Slocum's epic account of circumnavigation in the sloop Spray. ${ }^{58}$ The nautical theme was a good one: for here 
were two old pirates, both on the beach, watching the Hastings under full sail and still plotting how to board and take her. One of them finally made it aboard-but in the crew. William L. Prosser became a member of the 65 Club in 1963 and taught his specialty, Torts, there for nine years.

Prosser died in 1972. Robert Gordon Sproul lived until 1975. David Ellington Snodgrass was vouchsafed less life than his old adversaries, though he too made it into the 65 Club in 1959. On July 10, 1963, after heart surgery, he failed to regain consciousness. It was at least a quiet (and merciful) end to a marvellously turbulent career. 
IN MANy a law school over the past two decades those bitter-sweet affairs called retirement dinners, at which younger (sometimes not by much) colleagues bid goodbye to an eminent professor about to become emeritus, are enlivened by a little ditty. All join in lustily, some in tune, to the air of "Over the Hills to the Poorhouse":

I'm approaching the date of retirement,

Next year on July twenty-nine;

A statutory requirement,

For few die, and none will resign.

I'm tired, and weary of teaching,

Worn down by the ultimate straw;

I'm hopeful I soon will be reaching

The Hastings College of Law,

Where nobody reads any cases,

And nobody does any chore, And life is all lovely and lazy,

And nobody works any more.

There days go by without number

Like lilies afloat on a stream,

And no one's disturbing your slumber,

Or interrupting your dream.

No problems are ever suggested,

In quandaries no one is mired,

And quiet is requested

For those who have retired. 
There nobody reads any cases,

And nobody does any chore;

It's over the hill to Hastings

Where nobody works any more.

The process of daily digestion

Goes on without any surcease,

And no one proposes a question

Infringing that infinite peace.

In offices tasteful and cozy,

The faculty all take their rest;

And everything's golden and rosy

In that paradise out in the west,

Where nobody reads any cases,

And nobody does any chore;

It's over the hill to Hastings,

Where nobody works any more. ${ }^{1}$

The Greeks said that one could not be a poet without some foolishness; the same can be said of the dean of a major law school. The poet here qualified on both counts: William L. Prosser, who went over the hill to Hastings in 1963.

Paradise Hastings might be, but a retirement home it was not. That unique institution, Hastings' 65 Club, has been constituted of superannuated but not retired professors. For over three decades, the 65 Club has provided Hastings with one of the most distinguished faculties in any American law school. For two decades these professors, ranging in age from 65 to 86, bore the brunt of the teaching in the College. They revolutionized the program and curriculum. They brought almost instant fame to the College. Though for the past six years the instructional role of the 65 Club has been reduced, these seniors of the profession still provide Hastings with eminence by age.

The six 65ers hired between 1940 and 1947-Orrin Kip McMurray and Arthur M. Cathcart in 1940, Edward S. Thurston in 1943, Oliver Le Roy McCaskill and Chester G. Vernier in 1946, and Augustin Derby in 1947-did not constitute a "club." They were heralds of a new departure, but they were not the departure itself. 
In May 1942, Snodgrass attended the American Law Institute meeting in Philadelphia specifically to talk to the deans of Harvard, Yale, Pennsylvania, and Columbia about future staff for Hastings; the implication was that he was looking for younger, recent graduates of these institutions. In itself, Snodgrass' mission was significant. He was desirous of increasing the full-time faculty at Hastings and he wanted lawyers of a more academic type than the available pool of San Francisco practitioners provided. There had been some discussion in the Board about limiting part-time faculty to two courses each, and this was an indication of the dean's predilection for full-time instructors in the core of the program. The exigencies of wartime prevented any action from being taken-the College was lucky to get any instructors it could find. In the fall of 1945, in expectation of the GI bulge, the issue of limiting part-time instructors (to three semester hours) arose again. But of equal interest, the dean and the Board discussed compulsory retirement of faculty at age 75 . In December 1945 , the Board voted retirement at age 75 as "a rule of general application." In fact, while the rule remained on the books, it was never enforced. The GI deluge beginning in 1946, coupled with a general shortage of law teachers and the hot competition for them by all the rapidly expanding law schools, persuaded Snodgrass that the College's full-time faculty should be recruited almost exclusively from 65ers. By 1948, with the hiring of four 65ers (the largest number to date at one time), Lawrence Vold, Max Radin, Dudley O. McGovney, and Ernest G. Lorenzen; an article in Reader's Digest on the 65ers; and Snodgrass' almost automatic reply to jobseekers that the College was hiring no full-time faculty under age 65, it was clear that the "club" was in existence. In 1949, when Everett Fraser, William G. Hale, and George G. Bogert were hired, there was no question about Hastings' staffing policy.

Throughout the heaviest GI years, 1947 to 1951 , the 65ers provided about 40 percent of the College's 
instruction; 10 percent was undertaken by the three full-time professors under 65 (Snodgrass, Sammis, and the librarian), and 50 percent by the part-time faculty. In academic 1951-52, the 65ers accounted for almost 70 percent of instruction (an increase of 25 percent in one year). The number of 65ers did not increase-there were seven in that and the two preceding academic years. The increased percentage of instructional responsibility falling to the 65ers resulted from the rapid diminution of part-time instructors, from 20 in 1949-50 to 12 in $1950-51$ to 4 in 1951-52. With the GI bulge over, reduction was necessary, but it was the part-time faculty that was reduced, not the 65 Club.

The two decades' ascendency of the 65 Club began in 1951-52. From then until academic 1972-73, never less than 50 percent and as much as 90 percent (in 1963-64) of instruction was provided by 65ers. From seven in 1951-52, their numbers dropped to six for the next two academic years, but jumped in 1954-55 to ten and began a steady increase to a peak of 25 in 1970-71. The part-time faculty expanded and contracted only slightly, to never less than three or more than ten, between 1951-52 and 1968-69. During the same period, the full-time non-65 faculty numbered between three and five, and their instructional contribution in terms of total load was negligible from 1957-58 to 1971-72; they were, of course, primarily administrators. During the two decades of 65 Club ascendency, the average teaching load of a 65er was 7.7 hours per week; it was never less than 6.4, and in 1954-55 it went as high as 10.4 hours. During the same period, the average teaching load of part-time instructors was four hours per week. Taking into account that at the beginning of the period the average teaching load at a major law school was about 12 hours per week, and that this declined rapidly over the 1960s to about 9 hours, the Hastings 65er's 7.7 hours perhaps left time for "daily digestion," but didn't quite come up to Bill Prosser's wishful "nobody works any more." 
All of the Club continued teaching because they champed at the bit of enforced retirement. In many academic disciplines, retirement is often welcomed as an opportunity to continue research, to finish off the last big work of a career and a lifetime, unhampered by the daily routine of classes. In American academic law, scholarship is closely linked with teaching. Where in the humanities or the social sciences the major scholarly output of the researcher is to be found in the monograph or super-monograph, the law professor has three principal vehicles for scholarly activity of roughly equal importance: learned articles in law reviews; scholarly contributions to restatements of the law, to drafting of model codes and similar legislation, and to governmental commissions dealing with legal problems; and texts and casebooks. Of these, the latter two almost demand activity as a teacher. Texts and casebooks are often important contributions to scholarship, but they begin as teaching tools, and rarely has an academic lawyer involved in restatement of the law or codedrafting not found the thrust and parry of the classroom a valuable means for defining ideas and even for refining language used in the work. This is not to argue that the humanities or social sciences professor does not need teaching to undertake research (he does, rather more than he is likely to be aware of). It is to indicate that the law professor's scholarship relies less on the massive acquisition of data than on constant stimulation of ideas and remaining wholly up-to-date with-even ahead of-rapidly changing legal developments, and that the best way to maintain this grasp is to be bent to the discipline of conveying the law to students. With such an intimate link between teaching and scholarship in the law, forcing retirement at an arbitrary age not only can cost the classroom an experienced teacher, but also can cost legal scholarship a savant at the height of his powers.

However, something more was required than sunshine in "that paradise out in the west" to attract and 
keep scholars of the character and capacity of the 65 Club. The servant is worth his hire, and the 65ers could not be expected to continue laboring in the classroom for mere love of teaching. At first, there was wide variation in the salaries paid them. Some of the early 65ers, notably Augustin Derby, Ernest Lorenzen, and Lawrence Vold (all hired in 1948) were badly underpaid in comparison with others in the Club not one whit more distinguished. In 1948-49, for example, Derby was paid \$666 per semester unit-and taught 12 units-while Max Radin (also hired in 1948) was paid $\$ 2300$ per unit, and taught only four units. This inequity was less a matter of exploitation than a failure to establish a uniform pay scale. It grew in part, too, from star-catching; Snodgrass desperately wanted the luminous Radin's services, and Radin knew it and was prepared to profit by it. ${ }^{2}$ Indeed, the falling out in less than a semester between Snodgrass and Radin-for reasons that are still not clear-might have owed something to Snodgrass' regret that Radin had gotten out of him more than Snodgrass wanted to give, and more than he thought Radin was worth. Not long afterwards, a fixed unit scale was established for 65ers, the principle of which has obtained to this day. The scale has always been competitive with the highest salary step at Boalt. Sometimes it has been better than Boalt's. In 1954-55, Boalt's highest salary step was $\$ 10,596$; Hastings' for full time nonadministrative faculty (that is, 65ers) teaching a full load of 12 hours was $\$ 12,000$. Though from 1957 the state Department of Finance was committed to funding Hastings salaries at parity with Boalt, in the 1960s there was some slippage. In the 1970s, Hastings caught up with Boalt, which might be only cold comfort, since the University's scales have steadily eroded in comparison with those of universities of comparable standing.

The 65 Club would not have been possible if Hastings had had a retirement system or if the retirement systems of American universities made provision for forfeiture or reduction of pension for continuing em- 
ployment. The part-time nature of Hastings' faculty from its inception was determinative on the first count. As for the second, academic pensions were not under Social Security, and they were so mean anyway that forfeiture provisions were seldom seriously considered. One snag that would have cost Hastings the services of eight of its 65ers (three of them presently serving) would have been a decision by Sproul that Hastings was so integral a part of the University of California that the Regents' rules against continuing employment by retired University professors applied to the College. Sproul decided otherwise in 1940 in McMurray's case. This covered all cases of Boalt professors because the University had its own retirement system. However, Jno. U. Calkins, Jr. was prevented from joining the Club after his retirement as counsel to the Regents because he was pensioned under the State Employees' Retirement System, which imposed restrictions on continuing employment. ${ }^{3}$ At Snodgrass' insistence as early as 1945, the state attorney general had ruled that Hastings was exempt from the SERS, its professors excluded from membership in the system. He solicited and received the same opinion from two later attorneys general, including Edmund G. Brown in 1957, thus effectively keeping the College out of the grasp of the SERS and its mandatory retirement rule, which would have prevented hiring 65ers under any circumstances. How well the merely common-law marriage of Hastings and the University worked to Hastings' advantage is illustrated by the Hastings faculty's ineligibility for the University's own retirement system because they were not employees of the University, and their equal ineligibility for the SERS because by the act and the subsequent court decisions from Foltz v. Hoge to In re Students of Hastings College of the Law, Hastings was an "integral part" of the University. ${ }^{4}$

The basic structure of the 65 Club was determined by Snodgrass, and it has remained unchanged. In 1963, he articulated its philosophy: 
1. There is only one reason why retired professors cannot be recalled to active duty. That is the unwillingness of the local administration to receive them....

2. The physical condition of each member of an over-age faculty should determine the amount of teaching which he should be required to do....

3 . The salary scale for emeritus professors [continuing teaching] should be exactly the same as that which is applicable to professors who are teaching in their sixties. No deduction should be made because of the right to receive retirement benefits, which have been fully earned. ${ }^{5}$

For Snodgrass, the expedient of the 1940s became his crusade for the 1950s. Always a popular speaker and much in demand, by the mid-1950s he could not be persuaded to talk on any other subject than the iniquity of compulsory retirement. He did not lack an enthusiastic audience in the Golden State that was growing in population geometrically in large part by attracting retirees, in which the elderly were becoming a political force of considerable proportions, and which gave our language that infelicitous euphemism, "senior citizen." The 65 Club and its creator received national publicity, in Coronet, Look, Newsweek, on radio and television. In a San Francisco election for a superior court judge in 1960, Snodgrass roasted a candidate, aged 56, whose strategy it was to convince the electorate that his opponent, a 70-year-old lady municipal court judge, was too old for the job. That Lenore Underwood was a Hastings graduate, '32, merely added fuel to Snodgrass' torch, and though she lost the election, thereafter such a political strategy became less frequent. Snodgrass received numerous awards for his advocacy of the right of older people to work. He also enjoyed the kudos of the great and the small who congratulated him both on his cause and on the excellence of the faculty he had brought to Hastings. At the dedication luncheon for the new building, in March 1953, Director Sidney M. Ehrman, '98, a few months away from being an octogenarian, owned that if he were to present to the 65 Club a regimental standard (how apt a flag), it would be emblazoned with 
the words, "We declare we will never retire/ Until we lose our pep and fire." ${ }^{6}$ Those were Dean Snodgrass' sentiments exactly, and when he qualified for the 65 Club on September 11, 1959, his delight was downright boyish.

Snodgrass' active recruiting for the Club was very direct-a no answer was never gladly received, and the fierce little dean might have lured more than one great man to Hastings by engendering fear of his displeasure should his suit be spurned. Cornered, drink in hand, in a leather chair in the Cartoon Room at the Bohemian Club, even the most distinguished scholar was no match for Snodgrass' persuasive pleading. The nonagenarian Master, Roscoe Pound-who said no-felt compelled to go into considerable explanation (new furniture in Langdell, excellent working conditions, adequate extra income) for his refusal, softening the blow by saying that Snodgrass had "a wonderful faculty at Hastings College of the Law, and if I had the urge to resume law teaching I should certainly jump at the opportunity you offer." presented hazards. At one point, Snodgrass complained that most of the applicants for Hastings posts were superannuated practitioners rather than experienced teachers of law. His correspondence was full of ardent applications and his gentle discouragement. What Snodgrass sought were the best academics he could find. He well realized that he had a large pool of excellent local practitioners from which to draw part-time instructors for practice-oriented courses. For Snodgrass, the Club presented the opportunity to gain a scholarly faculty that the College could not acquire otherwise. He made the best of it. In the men he recruited and the institution he created he gave Hastings its richest legacy since the original gift of Serranus Clinton Hastings.

If imitation is the sincerest flattery, Hastings was much flattered by a number of law schools which by the end of the 1950s began to hire professors considered to be superannuated. Most of the schools were either as yet 
unaccredited or just recently approved, but all were aspiring to become better. California Western and the University of San Diego law schools took up the idea. Even the old and well-established University of Oregon law school enquired about the way to go about creating a 65 Club. Moreover, law schools with a mandatory retirement age began to agitate (and with some success) to "recall" retired professors to active service to teach a course. Indeed, Hastings stood in some danger of losing by its pathfinding. A few 65ers left to go to sunnier climes. But there were plenty to take their place. It is a true mark of distinction that today, as mandatory retirement begins to crumble, it was Hastings that first showed the way three decades ago.

To date, there have been 76 members of the 65 Club. Five of them in effect spent their teaching careers at Hastings. The indefatigable Robert W. Harrison might well be called the first 65er because he reached that age in 1937 and continued to teach until 1947. Brooks Cox, a practitioner, taught part time from 1946 to 1951 , and joined the Club and became full time in the latter year, continuing active until 1972. Harold G. Pickering, who was in practice in San Francisco from 1918 to 1953 , joined the Club in 1954 and remained until his retirement in 1963. Paul Basye taught part time from 1948 to 1966, then joined the Club and is still going strong, affectionately nicknamed the "Count," with obvious reference to a certain musician, but also to his aristocratic bearing. David Ellington Snodgrass was the fifth. Two other members had no previous teaching experience in a law school. Chauncey D. Leake, M.D., who founded the school of pharmacology at the University of California in San Francisco, taught medical jurisprudence at Hastings from 1963 to $1966 .{ }^{8}$ Arthur J. Goldberg, formerly associate justice of the United States Supreme Court (1962-65) and U.S. Ambassador to the United Nations in the Johnson administration, has been Distinguished Professor of Law at Hastings since 1975. 
The other 65ers who have come to Hastings from practice or the bench had previous law school teaching experience, full time or part time: Calvert Magruder (1959-60, taught at Harvard before becoming a justice of the U.S. Court of Appeals, First Circuit), Warren Madden (1961-71, taught at the University of Pittsburgh before taking a seat on the U.S. Court of Claims), Roger B. Traynor, who has held the chair endowed in his honor since 1970, after 30 years on the California Supreme Court, latterly as chief justice, had taught at Boalt for a decade, and Laurence Eldredge, a member of the Club since 1970, came from active practice in Philadelphia, where he also taught part time at Temple and earlier full time at Penn. All the rest of the 65 Club came to Hastings from regular full-time careers at other law schools.

The academic preparation of the 76 club members was of the highest order. Only two did not have the LL.B.: Dr. Leake and Arthur M. Cathcart. Cathcart spent a year at Harvard Law School in 1896-97, but prepared for the bar in a Colorado smalltown law office, a career pattern that was not unusual outside a large metropolitan area at that time. He practiced for one year, then went to Stanford in 1904, where in a thirtyfour year career he became one of the school's ornaments, teaching Pleading and making a major scholarly contribution as co-editor of a casebook on code pleading. Cathcart, with McMurray, was a charter member of the Club. Two were foreign-trained: Julius Stone, who read jurisprudence for the B.A. at Oxford and took the degree Bachelor of Civil Law there in 1929, and Moffatt Hancock, who received the S.J.D. at Osgoode Hall, Toronto, in 1940. Of the 72 graduates of American law schools, 49 (64.5 percent) received the LL.B. from seven major schools: Harvard (with 15 the highest number), Yale, Columbia, Chicago, Michigan, Stanford, and Boalt. Wisconsin and Iowa each produced three; Pennsylvania, Cornell, Illinois, Missouri, and the University of Washington each produced two; NYU (the closest Eastern cognate of Hastings), Northwestern, 
Minnesota, Texas, Nebraska, Montana, and Hastings each produced one. At the time that these men received their degrees, during the first three decades of this century (only McMurray from Hastings '93 and Robert W. Harrison from Harvard '98 are the exceptions), the "national" law schools were Harvard, Yale, Columbia, possibly Penn, Michigan, and Chicago. They produced then, and continue to produce now, a large proportion of academic lawyers, in great part because they have always enjoyed entree into major law firms in the Eastern and Midwestern metropolises, an inside track to Federal legal posts in Washington, and a preferential advantage in placing brand-new LL.B.s in clerkships to important appellate judges. Since the 1920s, such firms, posts, and clerkships, singly or in combination, have been the principal avenues to teaching positions for aspiring academics. But already by this time, most of the other law schools which produced many of the Club were excellent institutions with solid regional reputations. Most of these have since acquired "national" status, not only because they have grown steadily in size and quality, but because the Eastern dominance in law practice and in Washington has diminished. Conceivably, Harvard still affords a nose's length advantage, but not since New Deal days has the road to Washington required a left turn at Harvard Square.

Where the 76 taught before is even more significant. Excluding the seven who had either no prior teaching experience in law schools or had taught principally at Hastings, the remaining 69 had taught in 36 different law schools. Almost half of the Club's total membership came from seven of these schools:

$\begin{array}{lll}\text { Boalt } & 9 \text { professors } & 11.8 \text { percent of the total } \\ \text { Stanford } & 6 & 7.9 \\ \text { NYU } & 5 & 6.6 \\ \text { Illinois } & 5 & 6.6 \\ \text { Harvard } & 4 & 5.3 \\ \text { Michigan } & 4 & 5.3 \\ \text { Chicago } & 3 & 3.9\end{array}$


The fifteen (20 percent of the total) who merely moved their base of operation up the Peninsula or across the Bay provided the largest contingent. This should occasion no surprise; indeed is gratifying, because they did not labor under the Eastern suspicion of the Wild West, and they did not feel that Hastings was a comedown. The Boalt 65ers came in two major groups: McMurray (1940), McGovney and Radin (1948), and James P. McBaine (1952) in the early years, and Roger B. Traynor (from the state supreme court in 1970), Adrian Kragen and Stefan A. Riesenfeld (1974), and Arthur Sherry (1975) latterly, with Prosser sandwiched between (1963). Stanford provided a fairly steady stream early on, with Cathcart (1940), Chester G. Vernier (1946), William B. Owens (1953), and George E. Osborne (1958), followed by a break until John B. Hurlbut (1970) and Moffatt Hancock (1976). The NYU contingent was composed of Augustin Derby in 1947, Judson F. Falknor and Milton Green in 1966, Russell Niles in 1972, and Miguel de Capriles in 1974, all of whom followed in the trail of the first professor, John Norton Pomeroy, who remains a respected figure in the history of NYU. The train from Illinois began with Oliver LeRoy McCaskill in 1946, and in the later 1950s Hastings looked like an outpost of Champaign-Urbana, with the arrival of the "Illinois Gang": William E. Britton (1954), Albert J. Harno (1956), and George Goble (1958). This was in truth an affinity-group. Harno and Goble were old friends from Yale Law School student days, and the three had been the Illinois powerhouse of the 1930s and 1940s. Russell N. Sullivan, who arrived in 1967, had been a student of all three of them at Illinois, had succeeded Harno to the Illinois deanship, and like Harno played a prominent role in the reform of legal education in this country. The five from Illinois have given a total of 39 years of service to Hastings, the most of any law school (Boalt with 35.5 years and Stanford with 35 are the runners-up). Harvard's four include the third member of the Club, Edward S. 
Thurston (1943-48), much loved by his students, who created the College's first honor society to memorialize his name; James A. MacLachlan (1960-71); and Judge Calvert Magruder (1959-60) and Snodgrass' old friend Warren A. Seavey (1962-63) - the latter two staying only one year. The Chicago men, though only three, have been long-lived, and have provided a Chicago presence at Hastings for the past three decades: George G. Bogert (1949-59), Roscoe T. Steffen (1961-73), and Sheldon Tefft (1968 to the present). The three Chicago men shared a similarity in scholarly focus, on civil law subjects with origins in equity. Perhaps more significantly, Bogert and Tefft, both of whom joined the Chicago faculty in the late 1920s, manifested a concern with the jurisprudential foundations of the law, which flowered at Chicago from the 1930s through the 1950s.

The University of Washington produced three 65ers, Rudolph H. Nottelmann and John W. Richards, both of whom came in the $1960 \mathrm{~s}$, better known as teachers than as scholars, and Warren Shattuck, who came in 1974 after almost four decades at Washington, and is one of the most prolific and wideranging of the Club's scholars. Two 65ers each have come from Columbia, Cornell, Minnesota, North Carolina, Pennsylvania, Pittsburgh, and UCLA. The UCLA men have had remarkable associations with Hastings. Harold E. Verrall (1970 to the present) was a close friend of Arthur M. Sammis, registrar and dean from 1963 to 1971, and collaborated with him on a text on California community property law. Rollin Perkins was the third longest-tenured 65er, teaching for sixteen years from 1957 to 1973 , and though technically "retired," as a 65 er taught first-year Criminal Law until 1976, finally quitting the classroom at age 87 after almost six decades at the podium. Sixteen other law schools, including such notable institutions as Duke, Indiana, Iowa, Texas, USC, and Yale, and the Australian University of Sydney, provided one 65er each. 
All of the American law schools from which 65 Club members have been drawn were at least ABAapproved at the time of the 65er's recruitment, and with the exception of William Mitchell College of the Law, St. Paul (from which Stephen R. Curtis came in 1964), all were also AALS member institutions. This has been a matter of policy since the creation of the Club. Dean Snodgrass took seriously the notion that the $\mathrm{ABA}$ and AALS cachets were the mark of minimal standards of excellence for law schools. It is not to denigrate Stephen Curtis' ability as a teacher to voice a suspicion that his appointment as the only 65er from a non-AALS member school owed something to other considerations. Before becoming dean at William Mitchell in 1958, Curtis had been dean of Ohio Northern in Ada, Ohio, from 1955. There he had fought manfully and successfully to get $\mathrm{ONU}$ approved by the $\mathrm{ABA}$ despite the staunch opposition of Homer D. Crotty. No more than David Snodgrass would Arthur Sammis forget an old ally and fellow-sufferer at the hands of Crotty. Curtis' appointment was justifiable by the necessity of adding another section of Agency in the first year, and he was a distinguished teacher until his retirement in 1971.

As of the end of the present academic year, the Club's 76 members will have given Hastings 490 years of service. This is an average of just under six years and one semester of service per man. If we exclude the nine who stayed no longer than a year, the average length of service has been just over seven years. Among the past members of the Club, 14 served ten years or more. Brooks Cox is the laureate, with 21 years (1951-72), teaching Municipal Corporations and Civil Procedure. Cox, in practice in the City, taught part time from 1946 to 1951 , and joined the Club on reaching 65 . A man remembered for his modesty, Cox was a much-loved figure at Hastings; kind though never indulgent in the classroom, he was an almost perfect blend of academic 
lawyer and practitioner. Lawrence Vold, one of the early recruits, taught from 1948 to 1965 , a total of 17 years, after a career of almost a quarter of a century at Nebraska and Boston University. Perkins, with 16 years, holds third place. Two of the Club's most eminent members taught 15 years: Everett Fraser (1949-64), after 32 years at Minnesota (28 of them as dean), Snodgrass' stalwart lieutenant in the battle with the Bar Examiners and the ABA in the early 1950s; George Osborne, classmate of Snodgrass at Berkeley and Harvard, intimate friend during his years at Stanford and fellow Bohemian, a leading authority on mortgages and property security, remained actively teaching after his "retirement" in 1973. Lewis Simes, who came from Michigan, collaborated with Basye on a problembook on probate, and served 13 years (1959-72). Roscoe Steffen, for a dozen years, 1961 to 1973, made the dull stuff of Agency and Commercial Paper come alive, and his reputation as "challenging" in class meant not only "stimulating" but "probing." William Britton from Illinois and Norman Lattin from Ohio State served eleven years at Hastings (1963-74). The five who taught for ten years in the Club include Robert W. Harrison, who part time and full time from 1901 to 1947 taught at Hastings longer than any other faculty member in the College's history, Bogert from Chicago (1949-59), Judson Crane from Pittsburgh (1954-64), Judge Warren Madden (1961-71)—who had been a Pitt professor before going to the U.S. Court of Claims - and Richard R.B. Powell from Columbia (1963-73). Powell, whose first contact with Hastings had been under the somewhat strained circumstances of his 1927 visit on behalf of the AALS, latterly embraced the College and its program with fervor, bringing to Real Property the historical perspective that is too often missing when taught by younger professors. And with the publication in 1977 of his study of early California legal development, $1760-1860,{ }^{9}$ Powell both brought credit to Hastings and confirmed the 
widespread suspicion that he had become an adopted son of the Golden State.

Among the serving members of the Club, four have already served ten or more years. Milton Green from NYU has been at Hastings since 1966, teaching Civil Procedure, Conflicts, Federal Jurisdiction, and Practice. Paul Basye, with 12 years in the Club built upon 18 previous years part time, is the "dean" of the present faculty by virtue of his total tenure. Property and Probate are his subjects, but he taught physics and meteorology during World War II, and still gazes at clouds and stars. He has put his technical training to use in the ABA-sponsored project for computerization of land titles; as author of a treatise and editor of another on Titles, Basye is not about to allow Justitia to be gagged (she is already blindfolded) by the electronic marvel. Russell Sullivan, the last of the Illinois men, is still going strong after 11 years of teaching Constitutional Law. Sheldon Tefft, who came from Chicago in 1968, remains a firm advocate of the importance of equity as a branch of the law, and manages in Remedies to evoke the ghost of Pomeroy. As a student in jurisprudence at Oxford in the 1920s, Tefft found its program "at once more professional and less professional" than that at the University of Nebraska Law School from whence he had come. ${ }^{10}$ The longstanding English respect for equity was perhaps "less professional," but it made its mark on him.

Besides the teaching abilities and scholarly distinction of the 65ers, they brought to Hastings an inimitable quality of experience. The four judges, Goldberg, Madden, Magruder, and Traynor, had national, even international reputations as jurists. Dr. Leake was one of the nation's top half-dozen medical scientists in the 1960s. Laurence Eldredge, who established his reputation not only in published scholarship, but by an enviable career as an advocate, enjoyed a nationwide renown as a legal scholar in the field of torts and law and 
medicine of the sort seldom accorded a practitioner. Of the 65 members of the Club who came from other law schools, most had, of course, spent about 40 years in teaching. What is arresting is that on an average these 65 men had spent almost exactly a quarter of a century at the law school from which they went to Hastings. For an academic, long continuation at one place is a twoedged sword. It is easy to become too firmly set in the environment, overly involved in in-house politics and rivalries, smugly self-satisfied in having found a comfortable niche affording local recognition, and slowly seduced into increased inactivity because the competitive challenge of new surroundings, new people, and the need to prove oneself has evaporated. This is the pernicious edge of the sword. The salutary edge is caught in the old saw about the rolling stone gathering no moss. Frequent institutional change requires long periods of adjustment during which serious scholarship is impossible. Institutional loyalty, which makes for wholehearted professional involvement, takes time to grow, and frequent change nips it in the bud. Nothing erodes selfconfidence in the academic's sense of his powers more than rootlessness. Therefore, for most of the 65 Club members, their previous long tenure elsewhere afforded them the continuity to reach the peak of their powers, to make their professional marks, and to develop as accomplished teachers and productive scholars.

Another aspect of the 65ers experience was their administrative involvement in legal education. Twenty-nine of them (just under 40 percent of the 76) had been regular-not acting-deans of American law schools. One other, Julius Stone, was dean of the law faculty of the University of Sydney. The 29 deans of American schools had a combined experience of 386 years, an average of just under 14 years each, in that administrative office. The most experienced dean was Albert J. Harno, with 35 years at Illinois after two years at Washburn, and the year before he came to Hastings he was acting dean at UCLA. Harno was succeeded at 
Illinois by Russell Sullivan, whose ten years added to Harno's 35 provided 45 years of continuous Illinois deanship represented in the Club. Three successive deans of Boalt-McMurray, Edwin Dickinson, and Prosser-brought 38 years of continuous deanship at the same institution to Hastings. In Judson Crane and Charles B. Nutting, the University of Pittsburgh provided two deans, who served continuously from 1942 to 1952 , and Nutting later served another six years as dean of George Washington. George Washington had three very young deans between 1910 and 1923, all of whom ultimately became 65ers: Ernest G. Lorenzen, Everett Fraser, and Merton Ferson. Fraser was dean at Minnesota from 1920 to 1948; after an eight-year interlude, William Lockhart assumed the office and remained in it for 16 years. Ferson, after leaving George Washington, was dean at North Carolina for two years and then at Cincinnati for 20 years, 1926-46. William G. Hale had 27 years of deanship at Oregon, Washington (St. Louis), and USC. Benjamin Boyer was dean of Temple from 1947 to 1965 . Leon Green also held a deanship for 18 years, at Northwestern-where Arthur J. Goldberg was one of his students-before Green went to Texas. NYU gave Hastings Russell Niles and Miguel de Caprilles, who were successive deans there from 1948 to 1967. Cornell had been under the hand of both George G. Bogert (before he went to Chicago) for four years and William Ray Forrester for ten. In all, 25 law schools (not including Hastings, which provided 65er Snodgrass) had at one time or another been under the direction of a man who would later take to Hastings the memories of toil and glory, the knowledgeableness and sagacity gained from the decanal experience.

The deanship of an accredited law school has been a great deal more executive than administrative since 1920. It has only one cognate, the deanship of a medical school. All other types of deans pale into something only slightly better than insignificant in terms of extramural importance compared to these two. In major 
universities, where of late rotation of department chairmen usually takes place every four or five years, and rotation of deans every six or seven, the dean of the law school generally remains lashed to the rudder for a longer stint. In great part, such long tenure has less to do with internal administrative concerns than with the activity of the dean outside the university. The dean must exert weight directly proportionate to the eminence of his school in the dual professional constituency of the law school: the bar and the legal academic world. The annual convention of the ABA in August and the annual meeting of the AALS in December are the rock and the hard place (that Welshman William Lloyd Prosser might have said the hell and the ironworks) between which the dean is caught, the poles between which he gyrates. He must always at least show the flag. If he is to do his job properly, he must become a power in the councils of the AALS and at least an influential voice in the ABA. If he has the inclination, can find the time, and has something to contribute, active participation in the American Law Institute and its model-code work magnifies the dean's importance and redounds to his school's reputation. All of the 65ers who had been deans of AALS-member law schools brought with them a national reputation derived from their leadership in legal education, and as well the abundant contacts with bench and bar derived from such eminence.

A special luster attaches to those law school professors (usually but not invariably deans) who serve the one-year term of president of the AALS. Ten of the 65 ers over the years were former presidents of the AALS. McMurray was president in 1924 while dean of Boalt; two were presidents during the 1930s, three in the 1940s, two in the 1950s, and two in the 1960s. Those members of the Club not presidents of the AALS were active in other offices and in its sections. Similarly, most of the 65ers have been participants in sections of the $\mathrm{ABA}$; today, three of the Club are on the councils of 
ABA sections, and a fourth is on the governing council of the American Law Institute.

Perhaps such eminence comes as no surpriseinvolvement and honors are the expected lot of professional leaders. There are other dimensions to the 65ers, however, which are just as appreciated within the walls of the College as their extramural eminence. Miguel de Capriles, an Olympic medalist in fencing, who came to Hastings from NYU in 1974, received a special Olympic Order Medal in 1976 for his long contributions to the sport. George Osborne was an avid football fan, his loyalties in the Big Game torn between Cal where he had been a student and Stanford where he had taught for 35 years. Fittingly, the Hastings rugby team has been named in his honor. In a college where for many years student support assistance was negligible, 65ers, their old students and friends in their honor, have made notable contributions to scholarship and loan funds for Hastings students. Two of the three endowed chairs were given in honor of 65ers Robert W. Harrison and Roger B. Traynor. The video tape library center was given by E. Robert Wallach in honor of William L. Prosser, who had taught Wallach at Boalt. The Thurston Society, the College's first honor society, and the David E. Snodgrass Moot Court Competition commemorate two 65ers. The College community's appreciation of the work and the persons of the 65ers over the past three decades is caught up in such memorials, but the true measure of Hastings' affection and respect for the 65ers is apparent in the admiration of its students for vigorous professors a half-century older than they are.

It is amazing to an outsider how easy the relationship is between students and teachers so markedly older than they. This appears always to have been the case, judging by the recollections of old alumni who remember the early 65ers and those of the 1960s. In a society that has made a cult of youth, an aged professor is generally considered unable to "relate" to "young 
people," a figure to be treated with indifference, perhaps his fearsomeness to be feared, but not to be taken entirely seriously. This has not been the case at Hastings. Until the last few years there were no regular and only a few part-time teachers young enough to match society's image of the kind of teacher likely to be effective in teaching young people. For some 30 years, Hastings students have had to get used to men older than their fathers and even their grandfathers providing them with the bulk of their instruction in the law. Doubtless, in individual cases this took some getting used to. Some 65ers were crotchety and short-tempered-but they probably had been when they were younger. A few continued teaching too long; yet the overall record is one of men no less intellectually and physically vigorous than teachers elsewhere half their ages. The students responded with a special kind of respect that was compounded as much of love as of recognition of a fine intellect. When "Mac," for everyone at Hastings called Oliver Le Roy McCaskill that, reached his 75th birthday in December 1952, student after student presented him with a shiny red apple. This affectionate salute to a skillful teacher and kindly man was the last-and probably the highest-honor that that much-honored professor received, because he died just a few weeks later. The grand old men of the 65 Club, the sweet and the irritable, the loquacious and the taciturn, the bold and the diffident, made an impression on the minds of their young charges that has proven indelible and vital long after the professors have gone and the students themselves have drawn close to 65 . These alumni recall that they had been taught by great men, known the encouragement and the reproof of great men, been touched by great men. This remains a badge of pride, a mark of difference creating a particularly fond memory of times-and of great men-past. Memories of times past are not memories of times lost when greatness though aged has been verdant, and when the verdancy lives on. 
Put in the crudest actuarial terms, the 65ers have been a remarkably sound investment. To date, only four appear to have died during the academic term, thus necessitating emergency rearrangements of courses. Very few appear to have had to quit in midsemester because of failing health. Perhaps the saddest case was that of William Britton, one of the "Illinois Gang," who could not complete the spring semester in 1963 because of failing eyesight. Britton, with incredible determination, carried on as long as he could, but God doth not exact day labor light denied. Thirteen of the Club retired as octogenarians-Brooks Cox, at 86, claims that record, too. Seventeen ceased teaching between age 75 and 79. A faculty of comparable size composed of men less than 65 can hardly boast a better record in terms of death or disability during the academic year.

In 1972, the Board decided that henceforth a professor would retire at the end of the academic year in which he reached his 78th birthday. If he wishes to continue to teach a course on a semester-by-semester basis, he may be permitted to do so. The Board's intention was to reduce the amount of instruction carried by the 65 ers to 60 percent of the non-theory practice courses, which has worked out to be about 40 percent of the entire curriculum offering. This goal was attained within a couple of years after the retirement of a number of 65ers in 1973, and implementation of the policy since then. There was no general dissatisfaction with the work of the Club. On the contrary, the members of the 1970s have maintained as high an instructional standard and retained as much vigor as their predecessors. In part, the move was made because of increasing difficulty in recruiting as many 65ers as would be required to staff a first year with upwards of four sections in any one course in a school with 1500 students. Certainly, longevity has not decreased, but for the first time, in the $1970 \mathrm{~s}$ professors have begun to retire with at least adequate pensions, and economic 
necessity has had less influence on the decision to continue teaching than it had at the Club's inception and during its first three decades. Moreover, a balanced age-pattern in the faculty creates more flexibility in programming and makes the curriculum less dependent upon part-time, adjunct faculty for suppleness.

The most important consideration in seeking an age-spread has stemmed from necessary changes in the curriculum. The staple subjects of the older curriculum have virtually disappeared in the upper-class program, and new subjects have been created in a disorderly but stimulating manner, appearing with a suddenness that is both disconcerting and reassuring. The changes have been towards increasing specialization in the second and third years, reflecting the increasing specialization in the practice of the law. Specialization also testifies to the unhappy circumstance of the decreasing ability of the courts and the profession to deal with the increase in litigation and the growing mass of case-law produced by that litigation. The old categories of law have eroded irreparably. To a large extent those categories were determined by the nineteenth century arrangement still reflective of the Common Law's ancient forms of action. Torts was nearly all-inclusive of the actions involving wrongs to persons and property. Contract became in the nineteenth century a distinctive branch of the law governing formal relationships principally to a commercial end derived from certain of the old personal actions at common law. The distinctions between torts and contracts have steadily become smudged, particularly in terms of remedies. Specialization has further erased the features of the two branches of the law. Now, courses in Employment Discrimination, Environmental Quality Law, Intellectual Property Law-the last incorporating patent, trademark, copyright, trade secrets, and unfair competition law-and Suing the Government are necessary to provide narrowly focussed treatment of particular aspects of what were once torts and contracts, but which now are becoming a general law of 
"obligations" which begs categorization by the ghosts of the ancient forms of action. The new categorization is that of subject matter, by problem orientation. Problem-oriented law must find a place in the curriculum: Consumer Protection, Education Policy in the Law, Land Use Planning, Oil and Gas Law, Aviation Law, law of Broadcasting and Cable Communications Systems, Indian Tribes and Treaty Federalism are all new courses that echo the issues facing our society in the headlines of the daily paper. Problem-oriented law requires a command of up-to-date social science of the sort that the Legal Realists argued for in the early 1930s and which is difficult to acquire, and a technical grasp of the hard sciences which eludes most law professors. The "new-style" courses are not readily taught by professors trained 40 years ago; they are hard enough for bright, young academics trained yesterday. This consideration has also influenced the College to create a better agemix in the faculty.

Eminence by age in the full vigor of its youth not only served the College well, but served it better than any other manner of faculty staffing could have. Not only did it provide instant national recognition of the name, "Hastings," it brought together in a short space of time men who were in the forefront of the major changes in legal curriculum that changed the face of law school education in post World War II America. This was the long-term impact of the 65ers, and one which demands special attention. The short-term impact was no less important for the time. The ex-deans who rallied to the College's defense under the captaincy of Snodgrass in the face of attack from the Bar Examiners and the ABA were the best of the College's troops. They exerted an influence that could not be withstood without the walls, and their allegiance was the key to beating back the attackers. But they were not merely soldiersthe 65ers of the Snodgrass era were few enough in number and eminent enough in stature to be a kind of "general staff." With the 65ers, for the first time there 
emerged at Hastings a distinctive body, or even institution, that was something more than the sum of its parts, a real faculty in the sense of a group of professors having a direct say in the operation of the College. Where before the dean covered himself with the Directors and then made a decision determinative in almost every matter, great or small, that affected the College, after the advent of Everett Fraser, George Bogert, and William Green Hale in 1949, Snodgrass could not act with the same imperious directness as was his wont and in the College's tradition. Faculty meetings became frequent, and by the end of the 1950s faculty committees had evolved, providing continuous faculty participation in running the College. The faculty assumed almost total responsibility for curriculum and standards, although not for personnel and recruitment. If Snodgrass was the mightiest of the imperial deans who had begun with Slack, he was also going to prove to be the last. It was the 65 Club that brought to Hastings for the first time a measure of that collegial faculty responsibility, admittedly falling far short of control, that has become in this century a feature of higher education in America. This constituted a kind of greening, bringing the College into the mainstream of educational institutions-greening, through graying.

The arrival of the 65 Club to primacy and permanence about 1949 coincided with a general wave of reformist sentiment in American legal education. The country experienced again, as it had in the early $1920 \mathrm{~s}$, the exhilaration of release from wartime restrictions, the end of foregoing change "for the duration," and the enhanced sensitivity to the importance of change that accompanies war, especially great wars of national effort involving the entire citizenry. The yearning for change was fed by the World-Fit-For-Heroes syndrome which moved the victors (and particularly the Englishspeaking victors) of both great wars of this century. If the universalized yearning for change was novel, the 
changes sought were not. The aftermath of war primarily brought conversions to old causes that had struggled along for a decade or more without noticeable success. This was as true of law school reform as it was of a great many other reform movements in society-at-large.

There were many manifestations of the yearning. One, dealt with at some length in the last chapter, was California's particular concern that issued in the 1949 special survey board report. California in fact led the way-the 1949 report was the most comprehensive study of legal education undertaken in those postwar years. In 1948, legal educational reform found an organ in the first issue of the Journal of Legal Education, published by the AALS. Besides longer articles that brought virtually every aspect of law school activity under critical review, its section on "Law School Developments" provided a forum for essaying any new idea, good, bad, or indifferent, from any law professor, mighty, middling, or measly. The new journal was avidly read, and it enjoyed a greater influence during the first half-dozen years of its existence than it has since (though it remains useful). The monthly American Bar Association Journal had been in existence since the second decade of the century. Principally a professional journal, even a "trade magazine," as its critics outside the profession called it, the Journal in the late 1940s and early 1950s provided more space for legal academics than it had before. Of much less importance, the various law school reviews by 1950 were catching the note of reform; their readership was always limited and reformist articles were less noticed than the solid, scholarly pieces that gave the reviews currency among jurists and practitioners as well as academics. Still, the law reviews' impact was significant as a reflection of a more general concern.

A single volume of the Journal of Legal Education, Vol. 4 (1951-52), will illustrate the ferment. Russell N. Sullivan of Illinois surveyed the reforms already worked by the ABA and AALS on legal education and found that while the progress made was encouraging, "further 
emphasis should be placed in the future on the quality of legal education and somewhat less emphasis on the purely quantitative rules" for ABA approval and AALS membership. ${ }^{11}$ Edward S. Bade of Minnesota castigated 20 AALS-member law schools for having library holdings sufficient to meet the minimum standard for membership but wholly inadequate to provide a good legal training. ${ }^{12}$ A young professor at Florida, James R. Richardson, advocated greater emphasis on the moot court in the curriculum, not only for trial but also appelate experience, and provided a great many sensible guidelines for a sound moot-court program. ${ }^{13}$ Another article was the report of the AALS's committee on prelegal education. In 1950, the ABA had adopted a new rule for approved schools, requiring that they only accept students with at least three years of college training. The AALS was less determined about pre-legal training than the ABA, and the AALS committee was to determine whether or not the AALS should take a firm stand on the content of pre-legal education. The report was an all too typical committee effort. The committee's policy statement concluded that content could not be prescribed by requiring particular courses in college, but that "quality of training" for pre-law students should be education for language comprehension, for "critical understanding of the human institutions and values with which the law deals," and for "creative power in thinking." 14 This fell short of what Arthur T. Vanderbilt, chief justice of New Jersey, advocated in his 1944 report to the $\mathrm{ABA}$ on pre-legal education, ${ }^{15}$ and shorter still of the hopes of those who sought to make the law more reflective of social and economic realities by requiring thorough grounding in the social sciences for future lawyers. Perhaps the most significant contribution was that by a renowned teacher of Contracts, Edwin W. Patterson of Columbia. Weighing the merits and demerits of the case-method in law teaching, he concluded that the method remained the best instructional device possible, but that cases had to be supplemented by legisla- 
tion and non-legal materials that set the law in a broader social and economic context. ${ }^{16}$ Finally, a Black professor at the segregated Texas Southern University School of Law, Houston, William Beasley Harris, reminded the profession that there were new members of the law teaching profession in such state-supported Black schools, reported a survey of non-Black schools as to whether they would accept a Black professor (the replies were discouraging in the extreme), and voiced the hope that all would "join forces and insist that education be in a way of life that knows no color, race, or creed that will deny to any man equality before God and man." 17 If these articles are cited as illustration, they were in fact something more. They pretty well cover the principal areas of concern for law school reform that were surging through the academies and at least washing against the profession outside. If any concern was missing, it was supplied in a speech given by Dean Erwin N. Griswold of Harvard at the dedication of the Southwestern Legal Center at Dallas, and printed in the $A B A$ Journal for November $1951 .{ }^{18}$ Griswold emphasized the statutory nature of most new fields of law and the necessity to gain a better understanding of social and economic forces at work on the law. He called for law schools to become centers of research, especially collaborative research, on the model of contemporary medical schools, for the solution of legal problems through massive scholarly effort as adequately funded as scientific research. This was not the first time that legal social-engineering was advocated; what was unusual was the implicit call, from a Harvard dean, for government money to do it.

In 1945, the ABA's section on legal education and admissions to the bar set on foot a project called the Survey of the Legal Profession. The task was entrusted to Albert J. Harno, dean at Illinois. Harno consulted a wide spectrum of academic and practicing lawyers, and was "advised" by nine learned gentlemen, including Will Shafroth, who had carried on A.Z. Reed's annual 
survey of legal education, Shafroth's successor in that venture and Harno's colleague at Illinois, Russell N. Sullivan, Elliott Cheatham of Columbia, and, incidentally, two of Snodgrass' "enemies," James E. Brenner of Stanford and Herbert W. Clark. Harno and Cheatham both joined the 65 Club in the later 1950s; Sullivan came aboard in 1967. More interestingly, and more unusual, Harno took the advice of six non-lawyers, a Chicago businessman, an expert in medical economics, a businessman who had become president of Temple University, a Methodist college president with a business background, an MIT scientist, and the dean of Minnesota's school of business administration. Harno hoped that the survey would gain in value to the law schools by its having received both the critical evaluation of non-lawyers and their substantive contribution on how legal education might serve the wider community. After almost eight years of part-time research, Harno's report was published in 1953. Its faults were more apparent than its strengths. Too much attention was devoted to longpast historical background (Reed's work was better and more complete) and to the origins of professional involvement in legal education. Only two chapters, about one-fifth of the entire, relatively short work, were devoted to contemporary education in the law school. Worse yet, Harno was far too judicious; every proffered criticism was countered by its reply, and the impression is left that Harno not only carried briefs for both parties, but was equally effective in pleading on behalf of both. If Reed had been Jeremiah, Harno proved to be Job-he could suffer patiently. Yet Harno's effort is useful for its descriptive value, and sometimes by close analysis of the descriptive one can divine where Harno's heart was. The most striking passage dealt with diversity in legal education. Remarking that there was heavy emphasis on practice courses, Harno also noted:

There is a marked stress on the broader and more cultural areas-on a synthesis of the law and a fusion of legal and non-legal materials. This movement finds expression in var- 
ious ways. One is through changes in the content of casebooks. The modern casebook, as I have heretofore noted, bears little resemblance to the casebook of an earlier era. It no longer is a work made up exclusively of cases. Instead its content consists of cases interspersed with relevant readings and text materials from the area of the social sciences. ${ }^{19}$

There was nothing galvanic about Harno's observation, but it was accurate and reflected what had become the consensus among legal academics as to how law should be taught, and what law so taught was.

Harno, like most of his contemporaries, was both too polite and too timorous to make direct reference to the hottest debate that has ever raged in the halls of legal academe. In the aftermath of the First World War, when reformist sentiment had risen considerably, two men of commanding learning and remarkable intellect questioned the philosophical foundations of the Langdell/Ames case method of instruction. One was Jerome Frank, not an academic, but a New York lawyer who in the New Deal became an important figure on the legal side of FDR's alphabet agencies and finished his career as a Federal Appeals Court judge. In 1930, he published a stunning book ${ }^{20}$ on the judicial process which gave wide currency to the already perceived fact that judicial decisions are not always solely the result of logical deduction from the law as revealed in cases, but also in part the result of the mind-set of the judge, conditioned by his emotions as well as his non-legal learning and his experience. Given such circumstances, law could not be "pure," and therefore the jurist must among all his other skills and knowledge command disciplines that reflect the working of the law and that in turn ought to affect the direction of the law.

The other formidably intellectual figure was Karl Nickerson Llewellyn, a professor of Contracts and Sales at Columbia. Llewellyn came to the law by a circuitous route that involved a good deal more foreign study than most American academic lawyers of his generation enjoyed. He took his LL.B. at Yale in 1918, a J.D. in 1920, and taught there (with some New York practice) until 
he moved to Columbia in 1925. At Yale, Llewellyn was mightily influenced by his Contracts professor, Arthur L. Corbin. Corbin had long been dissatisfied with the assumption of the Langdell/Ames approach that study of the "right" cases, or the "good" cases, would yield a unity of doctrine that revealed a "pure" law. Corbin argued that all the cases must be studied and that the study begin with a close analysis of the factual situation giving rise to the case. Where the Langdellians sawand if they did not see it, they made it-consistency in doctrine, Corbin found inconsistency. Corbin was prepared to live with the inconsistency, to seek still for general principles of legal doctrine by virtue of similarity of cases raised by the factual situations of the cases. Llewellyn was not. For him, the law had to be broken down into as many discrete particles as the factual situations gave rise to. Like French politics, where there are as many parties as there are Frenchmen, in the law there are as many doctrines as there are cases. Such atomization eroded beyond retrieval the unitary doctrinal theory of Langdellianism. Corbin drew back from the abyss; Llewellyn dove in. In the process, he became a center of controversy (from which Corbin stood apart) and coined an infelicitous label for himself and likeminded academics-Realists - that became one pole in the contention with the Langdellians, who were the other. ${ }^{21}$

In 1930, the same year that Frank startled the legal world with his book, Karl Llewellyn published a teaching book on Sales, entitled Cases and Materials on Sales. The operative word is Materials. The usual principal cases were heavily supplemented by non-legal, historical, and economic analysis and even data, and to the principal cases were added digests of an enormous number of secondary cases. The book has been characterized as "unteachable," but Llewellyn had many other arrows to loose. ${ }^{22}$ A spate of law review articles over the 1930s were directed at the repeal of the Uniform Sales Act (drafted by Samuel Williston of Harvard) and the 
substitution for it of a uniform code incorporating actual business practices and where practicable giving them the force of law. The code was precisely the task Llewellyn himself undertook, under the auspices of the National Conference of Commissioners on Uniform State Laws and the American Law Institute, in creating the Uniform Commercial Code. By 1954, when the staff of bright young academics Llewellyn dragooned into service on the project had disbanded, an incalculable number of manhours had been expended in an heroic and successful effort to provide a thoroughly precise model code covering sales, commercial paper, letters of credit, foreign banking, title documents, secured transactions, and investment securities. Subsequently, the UCC has been adopted in every United States jurisdiction save Louisiana. The same atomization that Llewellyn brought to case law in Sales is built into the UCC. That has not impeded its usefulness-but it has encouraged a voluminous new case law that might seem the very antithesis of what a code is supposed to do. ${ }^{23}$ The great Coke said, De similibus idem est judicium, In like cases the judgment is the same $;^{24}$ the Realists came close to denying anything is the same, because all facts are different.

Llewellyn came in for more than his fair share of obloquy at the time, and not all of it as good natured as Prosser's doggerel:

Oh my darling U[niform] S[ales] A[ct], you're completely shot to hell,

And I'll never know my darling any more,

For thanks to Karl Llewellyn, now no mortal man can tell

What the law is, or will be evermore. ${ }^{25}$

The nihilism of some of his followers was laid at Llewellyn's door, but he was too creative and too learned to tumble into utter negation. He was a man possessed, one-tracked, never in repose, always quick to except to any criticism, quick to draw the sword in defense of his idée fixe of that jealous mistress, Justitia. During one of 
the seemingly interminable debates at the ALI meetings where the work of Llewellyn (as chief reporter) and his staff was criticized, amended, and ultimately passed, Grant Gilmore of Yale reported out a section to Article 6 of the proposed UCC dealing with travelers checks. A lawyer present, who represented a firm issuing travelers checks, made the tactical error of suggesting the search for a principle in the matter of liability for a forged check. Llewellyn rose as if Justitia was about to be ravished, and replied to the lawyer:

You see, I don't like to argue principle at any time, Mr. Johnson, in a Commercial Code. We heard the results of that, if you were here, and I fully sympathize with the results that you are reaching for.

Now, the line along which I should be talking if I were arguing principle-which I am not-would be that it is extremely bad for either an economic or academic community to have the choice of when people get their rights and when they don't get their rights, left in the uncontrolled discretion of the person who is about to give them their rights. And that is what I am not going to urge. ${ }^{26}$

Here were all the terrible old demons of Langdellianism about to rush back in again in an unguarded moment: purist (if not "pure") principle in doctrine allowing full play to the prejudices of the bench in judicial discretion, to the destruction of the real economic interests it is the law's task to serve.

The UCC might be considered the Realists' only victory. Perhaps even that must be denied them, because a great deal of the work done on the UCC was by those who would (and do) deny that they were ever Realists. Moreover, there are doubts that there were ever any Realists at all, beyond Karl Llewellyn's selfdescription. Even he came to deny that the Realists were a jurisprudential "school." The Realist vs. Langdellian controversy was tiresome; it was also very intense and consequently relatively shortlived. By the end of the 1930 s, everything to be said for either side had been, many times over. In fact, Langdellianism was already a dying, possibly dead horse, not least in its old stable, 
Langdell Hall. Of course, it is nearly impossible to stop floggers of dead horses when passions run high. What killed Langdellianism was the realization that there are no "right" cases, just many cases, from each of which one can derive comfort-new law, confirmation of old law, or simply more of the same law. Nothing quite fails like an idea that succeeds because almost everyone accepts its functional usefulness while denying its moral worth. By the end of the 1930s, of a decade of great depression, of social unrest, and of massive governmental activity directed at doing something about both economic feebleness and social reaction to it, there were few left who could accept the high-flying purity of doctrine that had been the very substance-and power-of Langdellianism. Rather like the Victorian minister who told the Commons that "we are all socialists now," there were few American academic lawyers who might not have admitted in candor that by 1940 they were all Realists. The extra-legal dimension of legal education, no matter how imperfectly practiced, how insufficiently learned, could not be banished from the law school.

There were, though, pockets of nonacceptancenot pockets of resistance, because that connotes more active hostility than was the case. The pockets of nonacceptance existed where the instruction in the law school was carried on principally by active practitioners who remained tightly bound to the law as they had learned it and wedded to the books from which they had learned it. Even as they had in their practice learned to deal with the new dimension (professional survival required no less), they had not in their teaching been able to shake off the limitations of the old ways. Until about 1950, Hastings was largely such a pocket of nonacceptance. Nowhere was this more apparent than in the teaching of one of the most lively academic lawyers at Hastings, David Ellington Snodgrass. Snodgrass taught Contracts, the very subject which was central to the Realist vs. Langdellian controversy. 
Recent scholarship has established beyond serious question how shallow were the historical roots of classical American contract law and how much Langdellian doctrinalism fashioned that branch of the law. ${ }^{27}$ The first Langdellian casebook was published in 1871: Christopher Columbus Langdell's Selection of Cases on the Law of Contracts. It was exactly what the title indicates, a "selection" of cases, of the "right" cases. Langdell was used by Pomeroy and Slack (Slack's own copy of the second edition, 1879, is in Boalt). The preface contained Langdell's famous assertion that "Law, considered as a science, consists of certain principles or doctrines." There were three chapters on mutual consent (the shortest), consideration (the next longest), and conditional contracts (the longest). The heart of the work - and the heart of the Langdellian construct of contracts-was the chapter on consideration. English cases predominate; that fitted Langdell's assumption that "Each of these doctrines has arrived at its present state by slow degrees; in other words, it is a growth, extending in many cases through centuries." It also testified less to the continuity of English common law in the United States than to how slight the real body of contract doctrine was; Langdell managed to create in a few years at Harvard what the English and American courts had not managed in the two and one-half centuries since Slade's Case! Two of Langdell's disciples also produced books for Contracts courses. William A. Keener, the Langdellian apostle to Columbia, published in 1891 a text containing selections from two English texts on Contracts supplemented by about half as many leading cases as Langdell's book contained. ${ }^{28}$ In 1894 , Samuel Williston, a young disciple at Harvard, published a casebook on Contracts by the same title as Langdell's, which was indeed seen by Williston as a continuation of Langdell's work. ${ }^{29}$ There were a great many more cases (and more American cases, especially), and the arrangement was very close to that of Keener's text. The doctrine that loomed largest was, of course, 
consideration. By 1894, there was no longer any doubt that consideration was the central stuff of contract law: not only had Langdell said so, but the courts had dutifully followed suit.

Williston was the prime target of Arthur L. Corbin's revisionism. There was nothing personal in it; they remained fast friends throughout their long lives. But to Corbin, Williston's treatment of consideration was the epitome of doctrinal blindness:

In the courts, the doctrine of consideration has gone its accustomed course. This course has involved an assumption that the term consideration has a simple and uniformly applied definition, that such a consideration is indispensable to the enforcement of any informal promise, and that the court's only function is one of deductive reasoning. The assumption has always been false; . . ${ }^{30}$

In 1921, Corbin published his own Cases on the Law of Contracts, based on both English and American decisions, but with "extensive critical notes" (as the subtitle put it). The doctrine of consideration was cut down considerably, to a fraction of the attention devoted to it by Williston. Such drastic surgery was possible because the courts already, under the pressures of changed economic circumstances, were applying other criteria to the validity of a contractual relationship than consideration. It was also possible because anti-Langdellians could play the Langdellian game, and by including all the cases find "better" cases to substitute for the Langdellians' "good" cases.

From the beginning of his teaching career at Hastings (at least) until 1950, Snodgrass used Williston's casebook. There were good, sentimental reasons why. Snodgrass admired Williston almost as much as he admired Roscoe Pound. In practice for Tidewater Associated Oil Co. in the early 1930s, Snodgrass found that Williston and the courts appeared to see eye-to-eye. By the later 1930s, that had certainly begun to change. Indeed, in 1942, Judge C. Goodell, in teaching Contracts (Snodgrass did not teach the course that year) used the 
first edition of Harold Shepherd's Cases and Materials on the Law of Contracts (1939). This was much influenced by the Realist position, evident in the inclusion of non-case materials and in attention given to such a remedial novelty as specific performance. Goodell gives point to the observation that the bench is usually in advance of the academy in accepting legal change. The same proved true in the case of at least one practitioner: part-time professor Brooks Cox, in teaching a second section of Contracts during the GI years, used Patterson and Goble, a casebook by Edwin W. Patterson of Columbia and George Goble of Illinois (a 65er from 1956), which was even more advanced than Shepherd in featuring non-case materials. ${ }^{31}$ In 1950, Snodgrass switched to Corbin. He stuck with it, apparently not without reservations, for another year, and then went back to Williston's fifth edition (1949). Williston had changed none at all. Though consideration had shrunk, there was still a marked devotion to other increasingly obsolete contract doctrines, and nothing on specific performance. The next year, 1953, Snodgrass returned to Corbin, and having made a final break with Langdellianism, went the rest of the way in 1954 with the adoption of the third edition of Shepherd. ${ }^{32}$ He continued to use Corbin occasionally, but in any event, he never backslid to Williston. David Ellington Snodgrass had taken the road to Damascus, and so he fought the good fight, kept the (new) faith, and finished the course.

It is impossible to say whether the conversion of Snodgrass would not have taken place but for the presence of the new old men of the 65 Club at Hastings. None of the 65ers can be tagged as Realists in the sense that they were disciples of Llewellyn and Frank. All of them, however, demonstrated the increased consciousness of the relevance and importance of non-doctrinal elements in the law that was current post World War II. They taught the old, classical courses of the curriculum in a non-classical way, with increasingly non-classical content. 
The 65ers were also ready and able to introduce at upper-class level new courses concentrating on more specialized aspects of the law taught in existing upperclass courses (still heavily directed at the bar examination) or courses on subjects not hitherto given at Hastings. It took a long time to get these talents fully used. In 1959, an $\mathrm{ABA}$ visiting committee found that the "curriculum is satisfactory, but lacks imagination and is too restrictive with respect to its elective program." ${ }_{33}$ This was just criticism. Snodgrass could not shake his fixation with the bar examination results, and he was unwilling to give much rein to innovation, though by then he had a faculty capable of creating anew. Some small, halting expansion came in the later 1960s, with a marked increase in the number of third-year electives; Dean Sammis did not share Snodgrass' fears. However, 65 ers continued to be hired for their primary subject, relevant to the bar examination. With the 1970 s and commitment to curriculum change, to broadening the upper-class program, and to abolishing the obsolete and meaningless distinction between second and third year courses, the 65ers were given their chance. All of them were versatile scholars, and a number of them were widely published in fields not represented on the bar examination. Their skills were utilized to bring into the curriculum Jurisprudence, International Law, Comparative Law, and a number of other subjects of which Hastings had been too long innocent. ${ }^{34}$

The curriculum reforms worked by the members of the 65 Club during their primacy were solidly founded on their scholarship. Not only had they passed careers in the classrooms of major law schools, but they had also written the texts and casebooks used at a great many other law schools. Only a half-dozen of the 76 were not leading, published scholars in their respective fields of academic law. Four of them have published texts or casebooks in Torts; three have been authorities on Contracts, and two have done casebooks in the subject. Eight have published extensively in Crimes and Criminal Pro- 
cedure, among them two authors of texts and casebooks, two of texts, and two of casebooks. Civil Procedure in one or another of its myriad forms claims nine authors. Property has been represented by eight authors, for a total of six casebooks and three texts. To turn to what are now upper-class courses, four Domestic Relations professors in the Club have published three casebooks and two texts. Constitutional Law has been the field of scholarly work of seven 65ers, who produced three casebooks, a book of readings, a text, and a number of monographs. Trusts occupied the major attention of four men, who published six casebooks and three texts; two of the same four have written on Future Interests and Estates in two casebooks and two texts. Probate constitutes two texts. Three 65ers produced six casebooks on mortgages and related fields (some with a local jurisdictional emphasis of the sort much favored by the Realists), and two texts. Sales, Negotiable Paper and Banking and Bills and Notes, Business Law and Corporations, Partnerships, Agency, Bankruptcy, and Labor Law have been represented by three to five scholars in each field, who produced texts and casebooks in profusion. Creditors' Rights and Remedies, Damages, Restitution, Federal Antitrust, Tax Law, Regulation of Public Utilities, Insurance, Patent Law, Press Law, Legislation, and Land Registration and Titles have all produced scholarly work including a number of texts and a few casebooks by one or two men in each. Conflicts and Comparative Law have each had three scholars publishing a wide range of scholarly and teaching books. International Law and Jurisprudence have been graced by some of the College's most eminent scholars, who have also not neglected teaching materials. This soulless library catalog deserves to be fleshed out by a more critical appreciation of their contributions than can be undertaken here. Yet, put briefly, everyone of these authors has made a major contribution to knowledge and the dissemination of knowledge of the law, and it has been up-to-date in its time. As the 65ers con- 
stitute half a millennium of teaching service to the College, so their scholarly publications would come close to being enough to stock a major teaching library for the law.

Only a much fuller treatment could do justice to the men, their scholarship, or their important contributions to Restatement, ${ }^{35}$ model codes, legislative drafting, service on commissions, advisory work to government, practice, government service, and on the bench. In the history of Hastings College of the Law, however, it will be remembered most about the 65ers that they were teachers. To their honor, perhaps even their glory, the distinction of their teaching rested heavily on their distinction as scholars. With the 65 Club, Hastings moved forward from being merely a law school-and a good one-to being a distinguished law school staffed by a distinguished, scholarly faculty. This was the seed of greatness, which planted, flourished. The 65ers have set the standard for the younger teachers who are now increasingly taking up their elders' burden. In institutions, nothing of greatness is lost unless the best is not followed by the best. It is not to discourage the new generation of younger faculty to remind them how high they must aim. 


\section{Beginning's End}

The Death of David Ellington Snodgrass was the end of an era. It was not, though, the beginning of another. The man who succeeded Dean Snodgrass, Arthur Maxwell Sammis, was never able to emerge from the shadow of his predecessor. This had less to do with any weakness in Sammis than with the incredibly enduring strength of Snodgrass' image. Arthur Sammis had lived and functioned too long in Snodgrass' shadow to be able, in the seven years of his administration as dean of Hastings, to be accepted as his own man on his own terms. That was a pity, because Sammis possessed strengths that Snodgrass lacked, and in raw administrative ability he was certainly Snodgrass' equal and possibly his superior. What he lacked was Snodgrass' activism, boldness, protean personality, combativeness, and penchant for self-advertisement. Sammis was an unpretentious man, an academic with a genuine scholarly bent, not abrasive in human relationships, a just man and a seeker of concord. He was not timorous or vapid. Highly principled, he was fearless in saying and doing what was right. Sammis when angry-which was much less often than was the case with Snodgrasscould be formidable. He enjoyed socializing less than did Snodgrass, but he was just as convivial with friends. Remarkably, in terms of originality and creativity, 
Sammis was on a par with Snodgrass; unlike Snodgrass, and in part because of him, Sammis had little opportunity to demonstrate his inventiveness.

Differences of personality aside, there were similarities in the backgrounds and interests of Sammis and Snodgrass that contributed to their closeness. Both came from the San Joaquin Valley and both were sons of farmers who subsequently left the soil for business. Sammis' father began as an olive grower in Wallace, Calaveras County, and then became general manager of a growers' cooperative which he helped establish. Sammis and Snodgrass shared a distaste for big government, big business, and big labor characteristic of the Valley's middle-folks. Republican politics accompanied the distaste, though Sammis was less conservative than Snodgrass. Both went to college in California, and neither felt inclined to affect any Eastern sophistication. Sammis also had served as an officer in the Navy (which pleased Snodgrass greatly). Finally, Sammis' interest in California community property law-in which he coedited the leading casebook ${ }^{1}$-and in future interests, corresponded with Snodgrass' practical bent and impatience with legal esoterica.

Young Arthur Sammis took some time to find himself. After graduating from high school in 1928, he worked for a year in Wallace before going to the College of the Pacific at Stockton. He switched to Modesto Junior College for his sophomore year, and to Berkeley for his junior year. He majored in chemistry, figuring that would be most useful for him in following in his father's footsteps in cannery management. His junior year at Berkeley was a disaster; he flunked out. He went to work. For four years, he worked in his father's cooperative, a Stockton cannery, and as a machinist in Alaskan packing plants during summers. He was adept with his hands, and long after he settled down to the law and legal education, he spent as many hours in his home workshop as he could find time for. In 1936, Sammis decided that while Wallace was a nice place to live in 
(especially if the hot Valley summer was avoided by working in Bristol Bay, Alaska), there was a great deal more to life than running a packing house. In April, he had married Eugenia Rutherford, whose father was district attorney in Napa and whose two brothers were in practice there. Eugenia urged him to try law. In August, he enrolled at Hastings College of the Law, which found his sparse academic credentials quite good enough. Bristol Bay Packing Company's lathe claimed him the next two summers, but during the remainder of each year he toiled away under the eagle eye of Dean Simmons and his faculty. And he succeeded, magnificently, attaining second place in the Class of '39. Of all his teachers, Snodgrass was the one who fired him most, and whom he most admired. His first job on leaving was as a trust officer with the Bank of America. He then served a year as secretary of the Bar Examiners (he had been a reader before), an experience that stood him, Snodgrass, and the College in good stead when the great row of the late ' 40 s erupted. After a year as an attorney with the War Labor Board, he joined a City law firm in 1944, at the same time joining Hastings' faculty as a part-time instructor. In July 1947, in the midst of the GI bulge, Snodgrass decided that Sammis was the man to second him in the administrative headache of the day, and he was appointed Registrar and Professor. Sammis gave up practice with his firm, in which he had become a junior partner. The remainder of his career and his life was devoted to Hastings with total commitment. He did keep his hand in the olive business, and summered when he could at the old place in Wallace. In later years, because of the oppressive summer heat, he had to forego even that pleasure. Arthur Sammis remained a countryman at heart.

Sammis' formal duties as Registrar were to maintain student records and, on delegation of the Board of Directors, to manage the College's finances and deal with its business. In fact, throughout the GI years, the routine administration of the College fell to Sammis, 
acting singlehandedly. There was no established division of labor between Dean Snodgrass and Registrar Sammis-Sammis did everything that Snodgrass didn't want to do, saw everybody that Snodgrass didn't want to see, and went everywhere that Snodgrass didn't want to go. With little significant change, this pattern continued until Sammis became dean in 1963. When Edward A. Hogan, Jr., left the USF deanship to become vice-dean at Hastings in February 1951 (at the same salary as Sammis'), he took on either entirely new duties, such as directing the revived moot court program and administering the new placement service, or the activities which Snodgrass had not hitherto delegated to anyone, especially curriculum planning. Sammis did everything he had done before, but now had to work in partnership with another. He even lost status-Vice-Dean Hogan's name preceded his in the catalogue, coming right after Snodgrass'. In 1953, Sammis was appointed "associate dean" as well as registrar; his position in the pecking order didn't change, and the new designation even appeared to confirm his inferiority. Sammis remarked ruefully, but without a hint of bitterness, in a letter to a friend, that though a raise had come with the new rank he would have received the raise anyway, and that the new title was "merely recognition of the fact that all of the duties that cannot be properly performed by an Assistant Janitor fall within my jurisdiction. The only thing now that has been added is the title!"2 That was a pretty astute job description of Sammis' duties from 1947 to 1963. Anyone less self-effacing than Arthur Sammis, having to work with anyone less kindly and sensitive than Edward Hogan, would have created an impossible situation. In fact, the two men were dear friends, and when Hogan died suddenly, aged 49, just as the new academic year began in 1957, no one grieved more than Sammis. And everything that Hogan had done as vice-dean fell to Sammis to do; he carried on alone because no successor to Hogan was ever appointed by Snodgrass. 
Snodgrass' apparent thoughtlessness, even cruelty, should not be misunderstood. Sammis stood very high in his affections. No one was ever closer to Snodgrass. Even during Hogan's tenure, it was Sammis whom Snodgrass principally relied upon to hold the fort while he was out fighting, sometimes to carry the first sally against the foe if that seemed tactically sound. Snodgrass travelled a great deal. While away, he and Sammis kept in almost daily contact by mail (the telephone was too expensive usually for the two countryboys' thriftiness). Whether Snodgrass was back East corralling $65 \mathrm{ers}$, rattling the ALI by his always active presence, gracing the smoke-filled suites of other deans at AALS meetings, or just relaxing at the Bohemian Grove, Sammis gave him a blow-by-blow description of what was happening at the College and in the City. An order from the general in Boston, New York, or Philadelphia was immediately carried out by his lieutenant in San Francisco. Never did Sammis take advantage either of his intimacy with Snodgrass or of his large area of responsibility to do anything that would derogate from Snodgrass' authority. In return, Snodgrass kept no secrets from Sammis and leaned heavily on his affection and loyalty in running the College. Finally, in 1960, a decent token of recognition came to Sammis. He was appointed the first Robert W. Harrison Professor, the chair established in his honor by old students and friends of that devotedly selfless member of the faculty.

The tragic death of Snodgrass on the operating table shook Sammis. Doubly. He lost a close friend and he had to take on the whole burden of the College as the academic year began. Sammis himself had just returned to work shortly before becoming acting dean on July 12 , 1963, two days after Snodgrass' death. In early May, Sammis had suffered six sharp heart attacks that had almost killed him. It is touching to read Snodgrass' last letters, full of unalloyed concern for Sammis, and then to read Sammis' letters shortly after Snodgrass' death, describing how Snodgrass had "been going on nerve 
alone for the past two or three years" 3 with heartvalves ruined by aortic stenosis. Sammis knew that he himself was a marked man-marked by the black daub of mortality-from the first day of his deanship. It gave him pause, but it did not stop him.

Snodgrass" "testament politique" was that Sammis succeed him. Indeed, there were rumors afloat shortly before Snodgrass died that he was going to retire and that Prosser, who had given up the Boalt deanship two years before and was about to retire as professor, would take his place. Snodgrass quashed the rumors by blunt denials, pointing out that if he quit, his successor would be Sammis. The Directors knew Sammis-as Registrar, he had attended virtually every Board meeting since 1947. The faculty, both 65ers and part-time teachers, had respect for Sammis and confidence in him. The Board took the unusual step of polling the entire faculty as to their recommendations for the new regular dean. The faculty were unanimous in favoring Sammis. ${ }^{4}$ In October 1963 Sammis was confirmed in the deanship. He was delighted, took great pleasure in the congratulations that flowed in upon him, but replied to them by saying that he did not think he could fill Snodgrass' shoes. Invariably he went on to point out, however, that he had shoes of his own, and he would do his best. Some even urged him to wear Snodgrass' famous eyeshade, but Sammis demurred; he would find some distinctive mark of his own in due course, said he. He never did. It probably would not have helped much to bring him out of the shadow of his enduring predecessor. Anyway, he was not unworthy of his predecessor, and in the seven years given him to direct the fortunes of the College, he made a number of valuable and important changes. If most of them were variations on a theme by Snodgrass, they were nonetheless substantial.

It took Sammis a year just to return the College to normal operation. He began it without even an assistant (his assistant registrar had left in March, and Sammis' heart attacks in May stemmed in part from having 
undertaken literally the work of three men). It was not until the beginning of academic 1964-65 that Richard Amandes, '53, was taken on as assistant dean, and Marvin J. Anderson from California Western was appointed Registrar. Enrollments went up in 1963, continuing the climb of some years past. Five new 65ers joined the faculty in August 1963, including Prosser, all of whom imposed the additional burden on Sammis of engaging them in the College's routine. All this Sammis handled alone, oppressed by the expectation of so many that he would continue as Snodgrass had begun, woefully unsure of himself, and not yet restored to even moderate good health.

The first major development undertaken by Sammis came in the spring of his first year at the helm. Since 1961, the College had given serious consideration to establishing a full-fledged legal clinic program. In 1960, John Bradway had joined the 65 Club after almost three decades at Duke. Bradway was still the missionary of legal clinical instruction, and within two years of coming to Hastings he managed to create a third-year course in the subject, which he taught in a class limited to 20 students admitted on the basis of their cumulative average. The emphasis in the course was on first-hand experience in interviewing clients, gathering facts, and preparing cases for trial and ultimate disposition. Director John Pigott was particularly interested in expanding the program. Sammis, more than Snodgrass, favored the program, and in early 1964 final plans were laid for 40 students to work in the offices of the San Francisco Legal Aid Society, and in the district attorney's and the public defender's offices. Bradway was put in charge, and the chief counsel to the Legal Aid Society, Thomas Rothwell, was appointed to the adjunct faculty to direct the afternoon office work of the students. From this humble beginning developed the clinical and externship programs which today offer ten courses in the practical application of the law learned in the classroom: in clinics in civil justice, criminal justice, discrimination, 
labor law, legal health, and trial practice, and in externships in trial court and public office and in public interest practice. Hundreds of upper-class students now avail themselves of the opportunity offered by one of the largest and best clinical law curricula in the country. Thomas Rothwell is presently the full-time director of the programs, a worthy successor in Bradway's apostolate. Bradway himself left in 1965 to carry the word to California Western, somewhat disappointed that Sammis would not accept his grander scheme of making the clinical project into an LL.M. graduate program. ${ }^{5}$

Most of the rest of Sammis' curriculum changes were less spectacular and not so fundamental. It fell to his successor to recast the upper-class curriculum. However, early in Sammis' tenure some important changes were made in Property, the second-year Property II giving way to a more sophisticated course in Trusts and Estates. Shortly after this change, the second-year Legal Research and Writing course was moved to the second semester of the first year where it would do more good, and where it remains. First-year Agency was expanded to include Partnership, and finally Agency and Partnership was moved to the second year. By the end of Sammis' deanship, the present first-year offering had come into being: Civil Procedure, Contracts, Criminal Law (with some procedure), Property (emphasis on realty), Torts, and Legal Writing and Research. The first-year course on Introduction to the Study of Law, an overview of the function of law in society with some jurisprudence and legal history, taught by Richard V. Carpenter, a 65er, flourished only briefly under Sammis. Its disappearance leaves the curriculum poorer, but the sudden rise and equally sudden fall of the course merely corresponded to a general phenomenon in American law schools in the 1960s.

All of Sammis' curriculum changes were made by faculty action upon proposal by a faculty curriculum committee. This procedure was a legacy from Snodgrass' last years, and reflected the prominence of the 65 
Club. What Snodgrass had not allowed to be delegated to the faculty was faculty appointments; in that vital realm his imperium was undiminished. Sammis did not take quite so high a view of decanal prerogative. He recognized that the eminent and experienced academics comprising the 65 Club could give invaluable advice in selecting new members of the faculty. They had been involved in the selection process where they had taught before, whether they had been deans or not. None of the major law schools after 1940 hired faculty without some procedure for faculty review, and in most such procedures had been in existence from the 1920s. Hastings, because of its previous reliance on part-time faculty and by virtue of its tradition of deanship, had lagged behind the norm in this. Sammis brought it up to date. It was he who insisted that the Directors poll the fulltime faculty for their advice on who should be the new permanent dean after Snodgrass; his courage was matched only by his confidence. Sammis also required that the full-time faculty act as a whole in confirming his appointment. Henceforth, he applied the same procedure to the selection of new faculty. A faculty appointments committee was established, and its recommendations, while subject to the dean's veto, would go forward for faculty confirmation before presentation to the Board. The role of the dean in appointments was not (and is not now) negligible and could be determinative, but the old way was banished forever by Sammis. With the new age-mix rules of the 1970 s, faculty involvement in appointments has become even more critical. The 65ers had a proven track record, had met the most searching review procedures of the best law schools, and after appointment at Hastings did not receive tenure. A mistake was hard to make under such circumstances and easy to correct if made. With the hiring of younger faculty who have not yet proved themselves and who, under the revised rules for tenure adopted by Hastings in the 1970s, will become permanent for a long career at the College, faculty review for 
appointment and for tenure is essential to safeguard the College's interests in obtaining and keeping only the best.

From a student's vantage point, educational institutions and prisons seem to have something in common. A professor's perception is different, of course, if for no other reason than that he's a "guard." There is something in the notion, because educational institutions, like prisons, are almost invariably overcrowded shortly after they are built. Snodgrass' pride and joy, $198 \mathrm{McAl}-$ lister, was no exception. The new building had been planned to accommodate 550 students comfortably, up to 1,000 in a pinch uncomfortably, for a short period. In fall 1963, Hastings' enrollment stood at 989; it had not been as low as 550 since 1958. Since the new building was occupied in 1953, enrollment had increased an average of 11 percent annually, and in 1962 it had jumped 21 percent and in 1963, 15 percent. As early as 1960, Snodgrass had cast covetous eyes around the neighborhood in search of space. The old Iris Hotel, adjacent to the College on its north side along Hyde Street, was the best site, since it would allow for the addition of a new wing contiguous to the school. Exploratory negotiations with the owners were delicate. State appropriation for purchase, razing, and planning and constructing a new wing had to go through the Regents, an exercise requiring careful handling. By the time Sammis took office it was clear that the College should go ahead. The increasing student enrollments were requiring additional sections in courses for all three years, and space was at a premium. The faculty, which was expanding rapidly, was increasingly ill-housed-offices were no longer "tasteful and cozy," or if they were cozy it was because of doubling up. It took Sammis two years to get the proposal beyond the mere planning stage with the University and the state. The possibility of securing federal money required further negotiations. Land acquisition waited upon a bond issue for the University. For four years, from 1965 until the handsome new wing was dedicated 
two days after Christmas 1969, Dean Sammis and Registrar Marvin J. Anderson were almost continuously occupied with the project. It all went too slowly. In 1967, some relief of overcrowding had been secured by leasing the old Bancroft-Whitney building on Hyde Street, currently state property, but the College had to secure legislation to prevent San Francisco State College from getting it for a downtown center. ${ }^{6}$ All this provided additional headaches.

The new wing was deservedly a cause for jubilation. The architects, successors to Masten and Hurd who had built 198 McAllister, executed a thoroughly contemporary building with an extraordinarily dramatic visual impact. The new faculty offices had prominent bay windows, which gave a somewhat castellated appearance to the structure-but that was, after all, in keeping with the architectural tradition of the university and appropriate to Hastings' continuing struggle for autonomy and adequate housing. On five floors, twelve more offices were made available, three classrooms of about 100 seats each permitted four sections of firstand second-year courses and three for the third year, and a splendid moot court room housed what had become a prominent feature of the College's program. A magnificent two-story library reading room, seminar rooms, typing room, conference room, offices for the Law Journal, and ample space for lounges, dining facilities, and lockers completed the whole. As the dedication brochure noted with guarded triumph, "Overcrowding, so familiar to many of the 4,000 alumni, will be eliminated-pro tem." Though the new addition made it possible to do justice to the 1,200 students of 1969 , the "pro tem" has already run out. Today, with 1,500 students, an expanded program, and higher expectations in legal education, the time has come to build again.

Tragically, for Arthur Sammis "pro tem" was all too short. He had less than a year to enjoy the new building, the attainment of which had required so much of his 
effort. His labors, on borrowed time for seven years, had taken a heavy toll. A few days before his 59th birthday in September 1970, he announced that he would retire as dean on February 1, 1971. On October 29, 1970, he died. His epitaph should be a line from an unsigned letter from a student, 20 years before, who had taken Future Interests from him: "The '65-Club' at school sets a very high standard for legal teaching, but you certainly measure up to that standard." " $\mathrm{He}$ was a fine teacher and a devoted administrator.

Nothing beset Sammis more during his administration than students-not in fine, but in gross. There were a great many of them, and more and more year-by-year, and they were an unusually yeasty and demanding lot. Sammis was probably better equipped by experience to deal with them than almost anybody else who might have been dean: He had begun his teaching and administrative career facing the GI bulge, and he had a very well-defined idea of what legal education was and what it was supposed to do. In coping with numbers of students and also their "non-negotiable demands" (always itemized), his idea of legal education, which was consonant with the College's traditional function, was an asset.

One early change worked by Sammis was a gradual phasing out of the old practice of taking as many who came and relying on high grading standards to winnow out the weak by the end of the first year. This was not an abrupt action, but was based on a strong, early intention of the new dean. He did not like the waste of effort and the harshness of the old way. Two developments gave him the means to effect a new admissions policy. One was the increasing number of applications. The other was an already higher basic admission requirement inherited from Snodgrass. Since 1955-56, a B.A. or its equivalent had been required of all entrants. This brought Hastings into conformity with the highest prevailing standard in American law schools. And from 
1961-62, applicants were required to take the Law School Admission Test, administered by the Educational Testing Service of Princeton, New Jersey. The LSAT measures aptitude for law school study by an objective-style of test for which it is almost impossible to prepare with much hope of significantly improving one's score. Its virtue is that it is as statistically uniform a test as can be devised. It is used nationwide, and over the years a sufficient body of test results has been built up to allow its use to predict the likelihood of success in law school. Its vices are two, one intrinsic and the other extrinsic. It is predicated, as are most "IQ" tests, on a cultural norm that seriously disadvantages culturally deprived persons; and cultural deprivation is in large part the result of economic deprivation. It is also seductive, in the sense that its quantitative score seems more solid than qualitative criteria, such as college grades and letters of recommendation. Despite these vices, law schools have relied increasingly on the LSAT score as a major, if not the principal assessment of a student for admission. Until the end of the 1960s, neither vice was much apparent. The B.A. requirement excluded a number of potential students who before would have sought and been accorded admission (Arthur Sammis was a case in point). Arguably, an applicant with a college degree was a better risk than one without. The LSAT was not employed with the rigor that has been used latterly, but it did enable the College to identify and exclude those who, according to scores and grades, were least likely to succeed. In 1963, for example, the bottom 30 percent of the applicants were excluded by combining LSAT scores and grades over four years of college. ${ }^{8}$

By 1963 , some steps had to be taken to reduce the number of entrants. The number of applicants was far outrunning the capacity of the facilities. This has continued to be true to the present. Graph 5 depicts the fall enrollments from 1954 to 1977 . The falling-off from 1965 to 1968 was caused by an act of policy, to get en- 


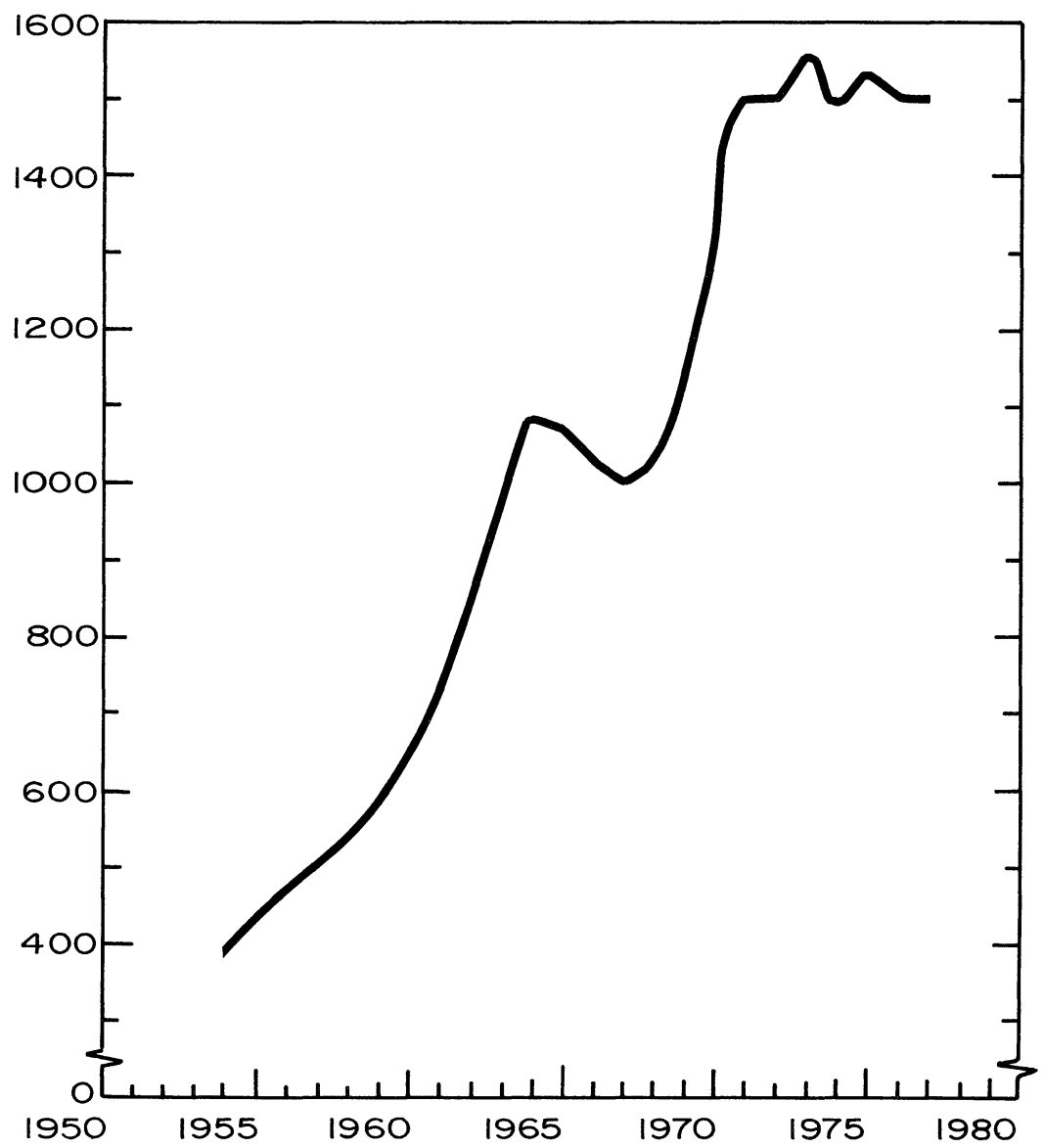

GraPH 5. Fall Enrollments at Hastings, 1954-1977

rollments down to 1000 after the high of 1088 students in 1964-65. Only with the completion of the new wing in 1969 were enrollments unleashed again, to spring up 13 percent over the figure for 1968. In 1971-72, the maximum-not optimum-figure for existing facilities was reached: 1500. That size of student body has been maintained since.

Over the 1960s and into the 1970s, three developments conspired to build up such an enormous demand for legal education. One was the "war baby" boom that stretched all educational facilities in the country; 
another was largescale immigration into California. The baby boom is over and immigration is slacking off. The third development, which is not abating, is the positive and purposeful commitment of a great many people, not all of them young, to acquire a legal education.

The law has always been an avenue to a wellrewarded profession and to political office. This is no less true today than it was yesterday. However, if the demand for politicians seems to remain fairly modest, the demand for lawyers in private practice and in public service has been increasing exponentially. Contributing to the demand is a marked rise in litigation. "Public interest law" has created a new class of litigants by increasing general awareness of legal rights and affirming the social value of asserting those rights. Also contributing to the demand is activist government, state and federal, but especially the latter, attempting wholesale changes by legislation in the body politic, economic, social, and cultural. Bureaucracy and its regulations have grown apace, demanding lawyers in government service and lawyers for those dealing with government. The frightening rise in crime has done its bit, adding to the demand for lawyers to prosecute and to defend. It is impossible today for any corporate entity to make a move without taking legal advice; it is becoming increasingly difficult for the individual-especially if he is rich or poor-not to seek legal assistance at some time. Our society is one in which virtually every relationship either has been or soon will be defined in legal terms, made subject to adjudication, and necessitating recourse to legal advice. Within the law itself, a number of subtle changes have accelerated the activity of legal institutions and lawyers. An increasingly fine definition of due process and its application to a broader range of circumstances have complicated the judicial process and increased the incidence of appeals. Too much legislation, badly drawn in excessive haste, without sufficient attention to its consequences, has demanded judicial interpretation which itself often unsettles the law. The list 
could go on. For something more than a decade, then, the legal profession has seemed to be an extraordinary opportunity for the ambitious.

Since the later 1960s, there has been a marked increase in the law's appeal that goes beyond mere pecuniary attractiveness. The law has become a way to do good while doing well. Again, public interest law is the key. Idealistic youth believes it can contribute to the commonweal, to the solution of pressing problems in our society, by activism in which the law is the instrument for change. This has been a constant refrain in the American law school for some years. The sincerity of it is not to be doubted, though its durability remains to be seen, both generally and specifically. Moreover, what appears to be a contraction in other vocational opportunities is turning college graduates to the law. Academic jobs are becoming scarce, and those who might have gone into teaching in the humanities or social sciences find law school an acceptable alternative. The natural sciences, pure and applied, are shrinking in their appeal for a great many reasons, not all of which are economic. The law recruits from among those who a generation ago would have become physicists or engineers. To judge by the decreasing population of seminaries, law schools also are making advocates out of many who a generation ago would have become preachers. Because the law school provides the shortest possible professional education of any major postgraduate institution save business school, it is unusually attractive in a time of high costs and job uncertainty. The same consideration enhances the law school's appeal to more mature people desirous of a career change-in many cases, from the kitchen-in middle age. Finally, the law school is one of the most accessible and rewarding educational institutions for aspiring minorities. In addition to all that it provides in future pecuniary and social advantages, it also opens the door to power and to the opportunity to serve the cultural group. 
The mounting number of students in the 1960s did not work much change in the geographic origins of the Hastings student body. From the years of the GI bulge and over the $1950 \mathrm{~s}$, about two-thirds of the students came from San Francisco and the Bay Area. In the 1960s, this proportion fell to between 45 and 55 percent. Despite higher admissions standards, Hastings continued to draw heavily from its old metropolitan constituency. This suggests that the higher standards for entrants merely caught up with a general increase in education among young people in the country as a whole. Significantly, Hastings did take proportionately more students from southern California than it had during the previous 30 years. The proportion of outof-state students doubled in the 1960 s, to about 15 percent of the total student body; this despite almost annual increases in out-of-state fees (Hastings followed the University faithfully in this), indicating that the College remained good value in competition with public institutions in other states and private institutions everywhere. During the 1970 s, the proportion of metropolitan students has declined somewhat, and the proportion of out-of-state students has increased significantly. One result of the latter phenomenon has been considerable pressure from Sacramento to cut back on out-of-state enrollments. The legislature's concern is understandable, but excessive restriction of admission to natives would fix parochialism on the College and cost the state the valuable asset of outside talent who come here as students and remain as professionals.

Sometime in the $1960 \mathrm{~s}$, the old Hastings tradition of the working-student eroded irreparably. In the aftermath of the ABA's attack on Hastings in 1950-51 for allowing students to undertake a significant amount of outside work, the faculty and administration became more sensitive to the issue. The 65ers were full-time teachers throughout their careers with scant sympathy for part-time students. The amount of class preparation required increased and class attendance was enforced. 
Consequently, by 1955 about half the students were not regularly employed, 30 percent worked up to 20 hours per week, and 8 percent worked more than 30 hours per week. In 1959,70 percent were not regularly employed, 14 percent worked as much as 20 hours per week, and only 1 percent over 30 hours. In 1964, these percentages were 78 percent with no regular employment, 13 percent up to 20 hours, and .2 percent over 30 hours. ${ }^{9}$ While the College still did not schedule afternoon classes save for multiple sections in first-year courses, it enforced with as much rigor as it could Saturday morning classes. Taking attendance was burdensome, and Saturday classes were no less an annoyance to faculty and administrators than they were to students. Snodgrass favored afternoon classes, but he could not persuade the Board to go along with him. ${ }^{10}$ By the end of the 1960s, Saturday classes were under heavy attack by students-indeed, the era of student activism at Hastings was ushered in in 1968 by agitation against Saturday classes. Saturday classes were finally abolished in 1969 and afternoon classes for all three years instituted in their place. Today, student employment figures less than ever before, and is negligible. Not only has a full five-day week contributed to the demise of outside employment, but the program at Hastings has continued to become tougher and more timeconsuming. Summer employment is the most that most students today can consistently afford to undertake.

The disappearance of outside employment has not proven a barrier to obtaining a Hastings degree. The prosperity of the 1960s enabled parents to provide support for their children, especially in a law school where fees were so modest. In 1953, the Board had taken the decisive step of adding to the meagre scholarship and loan funds available to Hastings students eight Hastings College Scholarships named in honor of the Founder, former deans, and eminent professors. ${ }^{11}$ The endowment came from the surplus GI Bill funds. Over the years these grew to 15 as former Directors and eminent 
alumni were honored. The scholarships were generous, and have increased in stipend. They also encouraged further endowments, providing over a score more scholarships since. None has been more significant than the Antenor Patiño, Jr. endowment, given by Mrs. Francesca Turner in memory of her son who died while a student at Hastings. This has provided both support for the child care center and major scholarships for worthy students of great potential in the law. The generous donation of loan funds has also supplied a real need.

With a student body of 1500 , made up increasingly of economically disadvantaged students, federal money has become a necessity. Since 1965-66, beginning with the work-study positions provided under Title 4 of the Higher Education Act of 1965, federal support for students has played an increasing role. Federally insured loan funds through banks with deferred repayment began in 1968, and were followed by the National Direct Student Loans, which provided for deferred repayment, a low interest rate, and possibility of remission of interest in return for public service. Loans have proven the most significant source of financial assistance at Hastings during the past decade. In 1969, the College began to receive Legal Education Opportunity Program funds to enable economically disadvantaged minority students to attend Hastings. The College's concern with minority entrants began in the aftermath of the murder of Martin Luther King, Jr., in 1968. Faculty, students, and alumni created a memorial fund in Dr. King's name to witness the "concern of the College in enlisting students, young men and women from minority groups, who meet our entrance requirements." 12 The Associated Students went further, and in 1968-69 for the first time made the ASH fee mandatory, with part of it earmarked for aid to minority students. Support for minority students, with both LEOP money and the College's own funds, has increased steadily over the years. Indeed, student support as a whole has grown steadily. Of 
late years, approximately half the students at Hastings have received some direct financial aid. Federal money (much of it on a matching basis with state funds) remains the foundation of financial assistance. It should not become the whole structure. Hopefully, the alumni and friends of Hastings who have given generously in the past will continue to do so to preserve a degree of autonomy in student assistance.

That fall day in 1964 in Berkeley when Mario Savio stood on top of a police car with Jack Weinberg inside it seemed to many who witnessed it the dawning of a new age. The hitherto apathetic students of America were rising to demand the Constitutional right of freespeech. The corollary was "academic freedom," whereby the role of administrators would be to make sure the bathrooms were supplied with toilet paper-Savio provided that job description at a later demonstration. Others who witnessed the first great event of the Free Speech Movement saw it not as a dawning but as the descent of a dark night of barbarism. It was neither. It was the opening shot of a turbulent era for American universities; it was also a shot heard round the world, as the torn-up paving stones of the Paris Left Bank proved in May 1968. The Free Speech Movement ushered in a Biblical seven years of troubles and turmoil, but the period did not profoundly change the nature, structure, or function of the university in American society. Those years, with such notable exceptions as the events at People's Park in Berkeley, Columbia, and Kent State, were not so violent as they appeared night after night on the six o'clock news (the movement learned early to schedule things so that the TV videotapers could work in full light and get the tapes to the wire services by 2 $\mathrm{pm})$. Confrontation, not riot or terrorism, was the tactic. Early success stiffened resistance and diluted support. Administrators learned how to be firm, flexible, and facile, with increasing success and an occasional triumph. The Vietnam war extended the life of the movement beyond its time, but deflected its attack from 
the university towards the government. Ultimately, the movement fragmented, becoming the ever-diminishing behemoth of increasingly particular interests. It dissipated rather than died, a victim of satiation of means rather than satisfaction of ends. All the bangs were over by 1972 , with only a few whimpers to come. It was rough while it lasted, though, and it mauled academic administrators as nothing else has in the nation's experience.

Hastings did not share in the early turmoil of its common-law partner across the Bay. Its students did not take part in the Free Speech Movement to any noticeable degree, but then their Boalt brethren were not very prominent in FSM either. The first rumblings of student unrest at Hastings occurred in 1968, and Saturday classes were the issue. It is hard to say to what extent the issue masked more deep-seated grievances. In any event, it was not without significance. Though Hastings students would become actively involved in the anti-war movement, the ecology movement, and most importantly in the movements for minority and women's rights, the focus of student activism at Hastings remained largely academic matters. The anti-war movement saw the protestors ranged on Civic Center Plaza and elsewhere, but not on Hastings' terrace. The ecology movement concentrated on course development. The steps taken to increase minority admissions in 1969, though it would be characterized as insignificant by those who demanded more of it five years later, defused a potentially explosive issue. What ran as a theme through student activism at Hastings from 1968 to 1972 , when it began to evaporate, was the demand for "improved legal education." This was an echo of the educational reform program that constituted the Berkeley faculty's misdirected, mistaken, and misleading reaction to FSM. It is at least likely that the large proportion of Berkeley graduates who were Hastings students in the late 1960s (21 percent of the students in 1968-69) brought this sentiment for reform with them. 
The Berkeley program was proposed by a special committee of the Academic Senate chaired by English Professor Charles Muscatine, and accepted by the Senate. The Muscatine Report can be summarized as proposing intimate faculty-student contact, student participation in curriculum planning, boldly conceived new courses to take the place of tired old courses, "relevancy" in education, and de-emphasis of grades, class standing, and such mechanistic paraphernalia considered to be choking the motivation for real learning. ${ }^{13}$

Intimate faculty-student contact was hardly possible in first-year courses, but Hastings students wanted more of it in upper-class courses. The problem was that the College did not have enough professors to staff seminar-size courses. At particularly tense moments in the years of student activism, the students received a bit too much intimate attention from some faculty: students complained of the nasty things professors had said in class about the movement. The activists seldom manifested the tolerance for others (for old men annoyed by what they could not appreciate and what they feared the consequences of) that they demanded as of right for themselves. They had a way of forgetting that free speech is a two-way street, and that academic freedom is meaningless outside the classroom and impossible if civility and academic purpose are not maintained in the classroom. The students' demand for educational reform was based on the argument that much of the existing curriculum was irrelevant to the new age dawned; that "relevant" courses would train the lawyer to tackle "real" issues in society and motivate him to accomplish the assurance of civil rights; that the 65ers were too set in their ways and too torpid to make any changes; and that the case method was mechanical and uninspiring, harshly and brutally used, an affront to the student's dignity. None of these complaints was particularly novel, though "relevant" had a freighted meaning limited to matters that the students considered crucially important. What was unusual was the assumption that 
student participation could reform all these shortcomings. The students demanded student evaluation of professorial performance, the evaluations to be given weight in the decision to retain or terminate a professor. The most stoutly attacked, in part because it was the most easily targeted grievance was the grading system. The demand was for pass-fail grading and the abolition of class-ranking. Relieved of the competitiveness of hierarchical grades, the student could learn happily, and without class-ranking invidious inequality would be banished.

Arthur Sammis found it difficult to cope with the demands and the stridency with which they were advanced. He believed in Hastings' traditional purpose of producing excellent practitioners learned in the fundamentals of the law. He mistrusted "relevancy" even as he saw it making converts at other law schools. Convinced that practice would continue to require grounding in fundamentals, he held that Hastings' graduates trained in the traditional manner would enjoy a competitive advantage over the "relevant" products of other schools. Sammis had a sincere commitment to academic freedom, which he conceived of in its conventional sense of freedom of the academic process in the classroom from the incursion of outside forces. He was a man of principle, and he didn't like being accused of dishonesty, hypocrisy, fraud, meanness, injustice, and all the other denigratory terms of confrontational rhetoric. Under pressure, Sammis tended to react sharply, even angrily, which did not do justice to his own judicious temperament and kindly decency. He was prepared to take a hard line in defense of the institution and its integrity as he understood it. Fortunately, he was seconded by a lieutenant of extremely even temper who could withstand great pressure without becoming rattled or angered. Marvin Anderson increasingly bore the brunt of the turmoil, and his imperturbability under fire, his spirit of compromise, and his willingness to lis- 
ten and to talk disarmed potentially violent confrontations.

As campus troubles went, Hastings got off lightly. There were no sit-ins. Occasionally large groups of students would confront the deans, but once heard outthreats and all-were always persuaded to leave. Picket lines were few and far between, and the size of the pickets' squads was moderate. At no time were police called in to keep order. There was a bomb scare, which, like the "bomb" itself, proved a wet squib. The Kent State crisis brought the only real milling about of students on the premises. There was only one case where a discipline hearing was called for, in 1970, after some disruption of the class of a professor accused of being antiwomen. Plenty of tension made nerves raw, but violence remained only verbal throughout these troubled years.

As Sammis' successor as dean, Marvin Anderson was in a position to deal with the reform demands of the students with more detachment than Sammis could muster. He was no less stout in defense of academic freedom, but he accepted that so long as the fundamentals of law were taught, and taught well, there was a place in the curriculum for problem-oriented courses, which by definition would be "relevant." He also saw the advantages of smaller classes, and particularly the stimulation that seminar instruction affords. With the full and ready participation of the faculty, in the course of his first few years as dean, Anderson restructured the curriculum.

The first year remained unchanged, but the distinction between second- and third-year courses was abolished, and upper-class courses were made totally elective save for moot court. The moot court, which had disappeared with World War II, had been revived in 1951 under the direction of Edward Hogan. Upon Snodgrass' death the moot court competition had been named in his honor. It grew under Sammis, and reached its full attainment with Anderson's reforms. 
The presence of a former U.S. or California Supreme Court justice or other leading jurist, a practicing attorney, and a third-year member of the moot court board as judges hearing appellate cases provides an invaluable learning experience for all upper-class students. The only other basic distinctions in upper-class work are between the case-method electives, the seminar courses, and moot court-which comprise the professional curriculum for the last two years-and the clinical and externship programs. "Relevant" courses-and the relevancy changes, of course-are spread over the range of the upper-class courses and programs. The result is a curriculum of great richness, variety, instructional diversity, and thoroughness.

In 1971-72, students were given the choice of three grading options: the old numerical-letter grade system, a four-tier system (indistinguishable from the old system save that "Fail" equalled " $D$ " and " $F$ " in the old system), and pass-fail. Subsequently, this grading method was modified by making certain courses subject to numerical-letter grades and others to pass-fail, with non-numerical, strictly letter grades for non-examination courses. Hastings' experience was the same as that of most other law schools which attempted to convert to pass-fail in whole or in great part and to abolish class-ranking. The students came to prefer more concrete methods of measuring success because employers were reluctant to hire graduates whose records did not provide some clear indication of relative accomplishment. Class-ranking was abolished, though lately it has made something of a comeback since individual student requests for ranking are honored; again, the employers have had the last word.

Student participation in curriculum planning was a harder bone of contention to deal with. After considerable discussion, forums, and public meetings involving students, administrators, and faculty, a structure was hammered out in 1973 by which four students, two of 
them alternates, are members of the curriculum committee, the other members of which are five professors. The students have two votes. Once suspicions declined and a consensus was arrived at that the job of the committee was the unspectacular one of improving the curriculum, student collaboration became a valued contribution. Student participation on the faculty appointments committee was not allowed, but student input in the form of evaluation of each individual professor's teaching has been accepted for the past five years as one of a number of kinds of evidence upon which retention and tenure decisions are made.

By 1972, student opinion began to change. Activism found its principal outlets off-campus, especially in the anti-war movement, which began to smell success. A great many of the entering students at Hastings had begun to sense that they had manned the barricades (literally and figuratively) long enough in college, and that professional goals should take precedence in professional school. The curriculum reforms worked by Anderson and the faculty satisfied all but the hardcore activists that changes were well started and advancing rapidly. The big internal concerns had become the working out of the details of student participation in curriculum planning and of how student evaluation of professors should be utilized. Something of a chill wind blew through 198 McAllister as federal money began to tighten up; that wind would continue to blow and get chillier in 1974-75 when there was an actual contraction of federal student support. The last commotion came in 1975, with picket lines in support of a more thoroughgoing special admissions program for minority students and a demand for the firing of the lady assistant dean in charge of student affairs and the LEOP on the grounds that she was "insensitive" to minority interests. A coalition of three activist groups on campus, led by the Third World Caucus, mounted the campaign. What was more significant than the hullabaloo was that 
the assistant dean was warmly defended by a great many students, publicly and in print. She remained on the job, and the agitation centering on her faded.

If the point the demonstrators intended to make was that there should be more minority students, that was never in question. From the late 1940s, the College had graduated an increasing number of Black students, many of whom had risen to positions of prominence. Today, the first Black state supreme court justice, majority leader in the legislature, and mayor of Oakland are Hastings graduates. Asian-Americans had provided a steady stream of graduates from the third decade of the century. Mexican-American recruits were slower in coming, but their number increased in the 1960s. By the mid-1970s, the number of NativeAmericans at Hastings was second only to the number at the University of New Mexico. At the time of the 1975 demonstration for increased special admissions of minorities, the College was in process of evolving the present student-faculty cooperation procedures for evaluating economically disadvantaged applicants, the student evaluator coming from the ethnic group of the applicant under consideration. This system works well; it has helped to increase the number of LEOP students and to assure that those admitted have a realistic hope for success. Since the emphasis is on economic disadvantage rather than on race or ethnicity, the current program has a good chance of surviving even if the United States Supreme Court upholds the decision of the California Supreme Court in Bakke vs. The Regents of the University of California. ${ }^{14}$

The positive legacy of the years of student activism is evident in the changed curriculum, increased student participation in the academic life of the College, and greater responsiveness to student sensitivities. The idealism of the students, even when the vehicle for it was less than ideal and less than idealistic, was not lost on their elders. Moreover, as in the GI years a quartercentury earlier, the spurt given to student involvement 


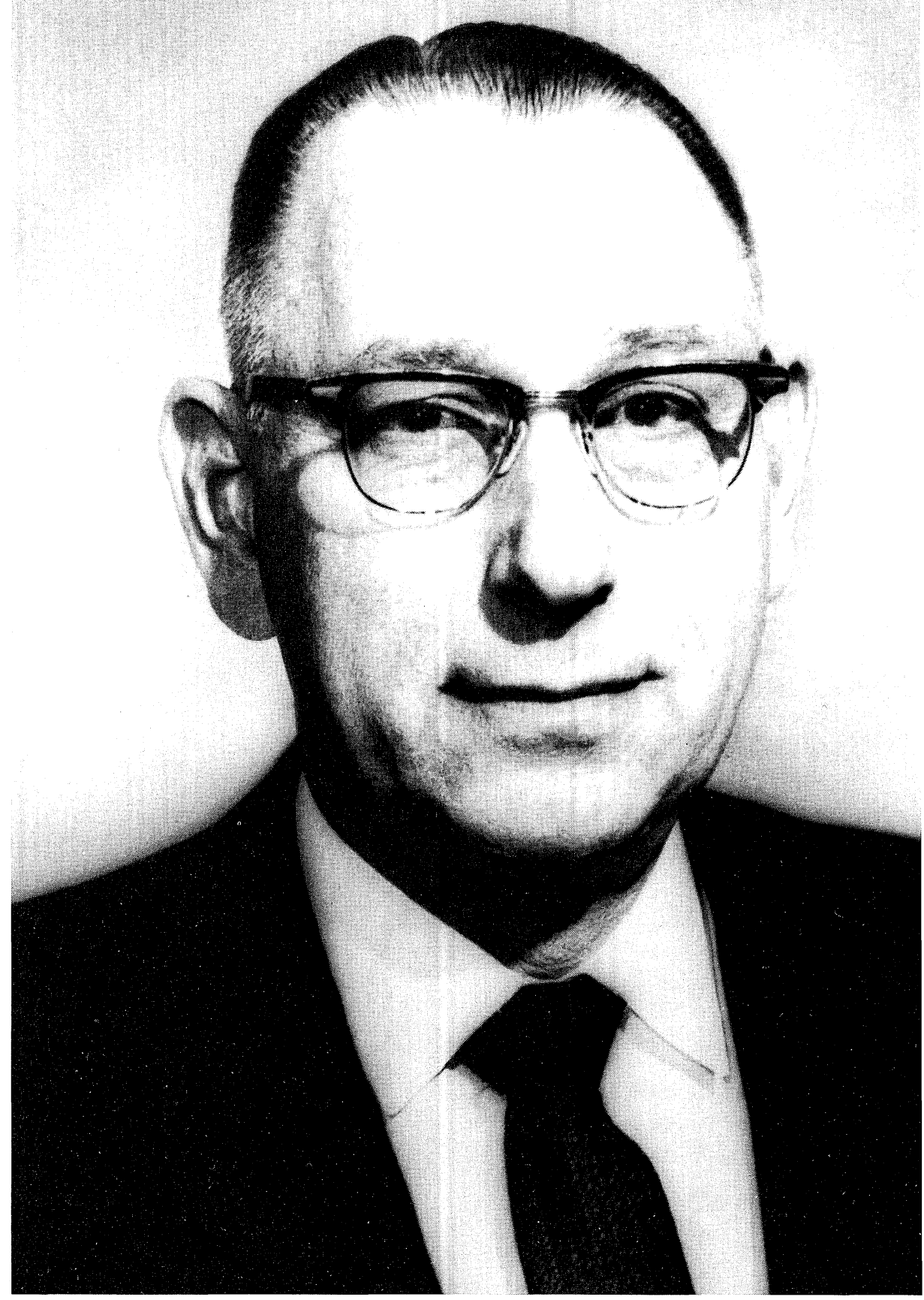

Arthur M. Sammis 


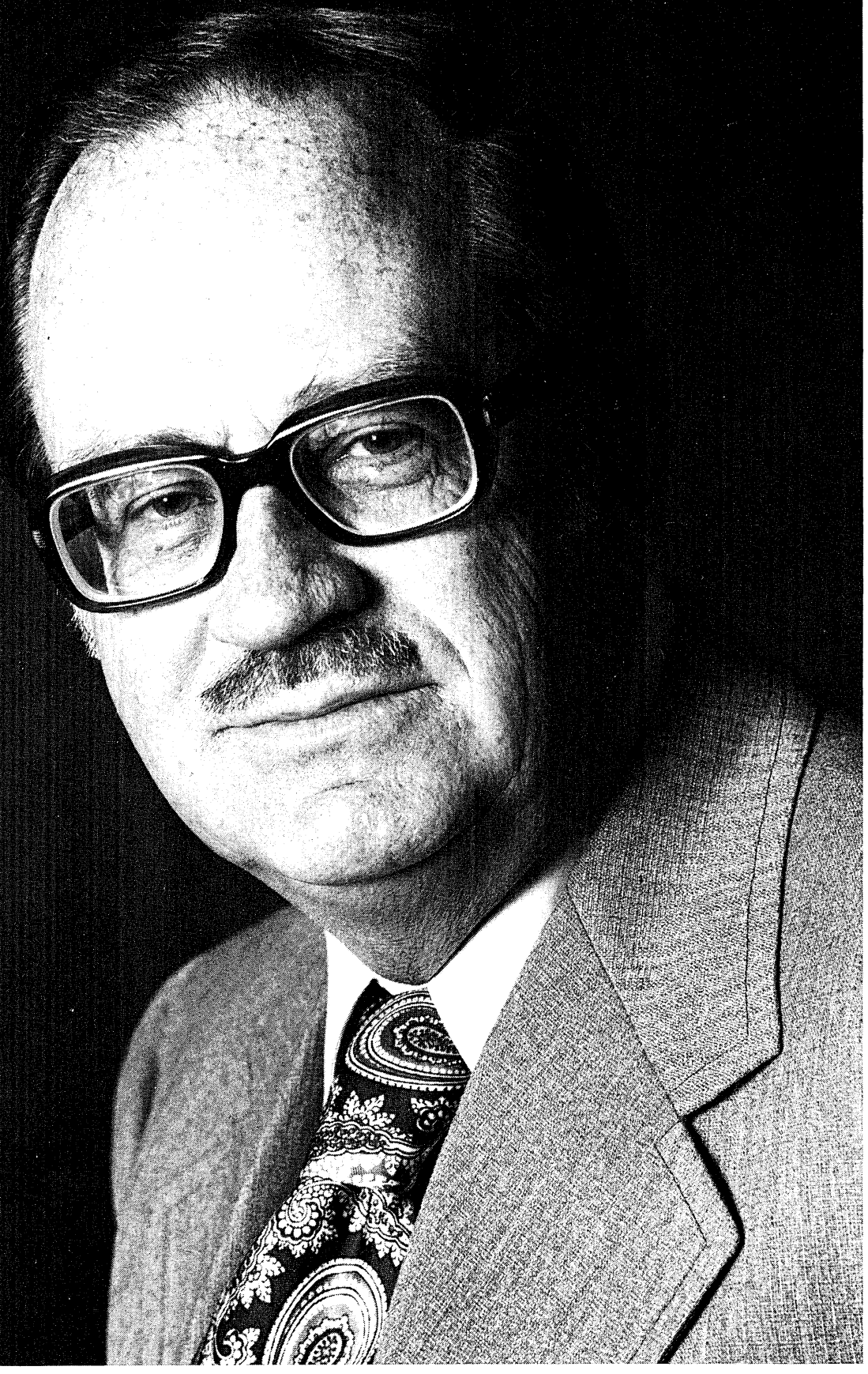

Marvin J. Anderson 
revived student institutions which had become dormant or somnolent and created new ones. The Associated Students was given a new lease on life, and has come to exercise a general watching brief for student interests. A couple of years ago, ASH sponsored, albeit unsuccessfully, legislation to change the composition of the Board of Directors; questions of the constitutionality of the proposed act aside, there is not quite the "generation gap" the ASH perceived between the students and the Directors, and by virtue of the growth of the College the role of the Board is more that of an overseer than of a participant in College governance. The student newspaper, the Hastings Law News, still thunders when it senses injustice or callous disregard for student interests and aspirations. Three new student-run law reviews have come into existence, addressed to the increasing specialization of the law and student interest in it: The Hastings Constitutional Law Quarterly (1975), The Hastings International and Comparative Law Review (1977), and Comm/Ent, a journal of communications and entertainment law (1978). Student responsibility for the David E. Snodgrass Moot Court Competition has increased by the agency of the moot court board, and through it Hastings students participate in national moot competitions. The traditional legal honor and fraternal societies have been given a new lease on life: the Thurston Society, the Order of the Coif, and three fraternities as well as the sorority, Kappa Beta Pi. As signs of the times, the Clara Foltz Society of Women Law Students, and the ethnic Asian, Black, La Raza, and Native American Law Student Associations are active in recruitment, counseling, placement, and social functions. The old Hastings Law Wives has recently been renamed the Hastings Law Partners, in recognition that whereas women as short a time ago as 1969-70 represented a little over 7 percent of the student body, in 1976-77 they comprised almost half of it. More women, more minority students, older and more mature students, students whose college training was taken out- 
of-state, all are becoming prominent at Hastings. Today's students are bright and well-prepared for law school. There are many fewer marginal students than there were even a decade ago. The median grade point average is now about 3.50 (B plus), the median LSAT score about 670 (out of a possible 800 ), and with 10 applicants for every place in the entering class, the college can afford to be choosy. Things have settled down in the once-turbulent arena of student affairs, but the old easy assumption that students are more likely to accept than reject the reasoned wisdom of professors and deans is not the basis on which anyone can afford to operate anymore.

The advent of Marvin J. Anderson to the deanship on the death of Sammis in October 1970 did signal a new era. Anderson did not become dean in Sammis' shadow. Sammis created no shadow-it was not his character or instinct to leave an indelible mark. Already Anderson had in the process of faithfully and diligently assisting Sammis begun to influence the direction of the College. He had the unique distinction of being deandesignate before Sammis' death; upon submission of Sammis' resignation to take effect some months later, the Board named Anderson his successor. When Sammis died, Anderson was immediately confirmed in the deanship.

The new era has not marked a break with the past of Hastings College of the Law. Rather, it is one of many new beginnings, but more significant than many that preceded it because the College now faces its second century. All at Hastings are aware of this. In recognizing the continuity of the past, Hastings accepts the first century as the end of its beginning.

Marvin Anderson differs from his predecessors in a number of significant ways. Unlike all Hastings' deans from Slack onwards, he was not either a native-born Californian or an arrival who came to the state in his youth before or at the outset of his career. Unlike them, 
he was a full-time teacher in another law school for some years before joining the faculty at Hastings. Unlike his predecessors, he has not practiced law in California. In short, he was formed in a different ambience than that which marked his predecessors. He has not remained a foreigner to California's manners and mores, but his perspective is less provincial than that of his predecessors. He is more an urbanite than a countryman, and the big cities of the Midwest and the West in which he has lived induced in him a sensitivity to urban problems that is reflected in the sense of metropolitan purpose he sees for Hastings in its next century. A Midwesterner, raised in Wisconsin and educated at its great state university, he was admitted there after receiving his LL.B. in 1942. He practiced both in Wisconsin and in Detroit, specializing in corporation insurànce and workmen's compensation. In 1959, he joined the faculty of California Western in San Diego. For three summers he was a Ford Foundation fellow at NYU, from which he received the LL.M. in 1964-the first Hastings dean to have taken graduate work and a graduate degree in law. He cut his teeth in administration at California Western, which was what recommended him to Sammis, who appointed him professor and acting Registrar at Hastings in 1964. The indications of his expanding role in the College and Sammis' growing reliance upon him were his regularization as Registrar and appointment as assistant dean in 1965, promotion to associate dean in 1967, and to vice-dean in 1969.

Anderson has taught a gamut of courses, with specializations in Constitutional Law, Administrative Law, and legal clinic programs. Reflective, well read, broadly experienced, he can summon a wide range of learning in law, philosophy, history, literature, religion, and the social sciences to give depth to thought and meaning to an address. He is low-key in his approach to administration. Articulate without being loquacious, he thinks before he speaks, and delivers himself with a quiet, disarming diffidence that lends weight to his words. He is 
engaging, convivial, and able to take the chaff of friendly intercourse in good spirit. His organizational abilities are exceptional, his diligence is unstinting, and his purposefulness is unswerving. He excels at planning and execution, his instincts are for program building, and he takes a very high view of the nature of legal education and the purposes it is to serve.

The new administration's first order of business was to meet the challenges of student demands. Curriculum changes, the increased number of courses of smaller size on specialized topics, changes in grading practices, engagement of students in the academic functioning of the College, and the expansion of opportunities for minorities and women were accomplished in a short period of time. Anderson had to restrain the student constituency and bring along with him the faculty constituency, mollify alumni fears, and reassure the legal profession that Hastings was still producing lawyers, not revolutionaries. Many administrators elsewhere attempted the same with much less success. The establishment of a child care center provided an essential facility to encourage women to enter law school. Women professors and women in major administrative offices became increasingly prominent. The ethnic complexion of the faculty began to change, with young professors from minority groups bringing a new perspective on law and a more acute concern for law and social needs. A smooth transition to a new age-mix in the faculty made broader recruitment possible and induced curriculum innovation. In a few years more program and personnel changes were wrought at Hastings than ever before. To top it all-and to undergird allthe library was brought to a genuine level of excellence and sufficiency, with 150,000 volumes. The library budget is now just under $\$ 500,000$ a year. The ghost of Charles William Slack hovers approvingly.

Curriculum and personnel changes, library growth, and the expansion of opportunities for minorities and women have demanded a level of state support without 
parallel in the College's long history. The foundations laid during Sammis' tenure-in which Anderson had played a major role in preparing budget and seeing it through Sacramento-had doubled state support between 1964 and 1969 to almost $\$ 1,000,000$. In the first seven years of his tenure, Anderson increased state support to three and one-half times of what it had been in 1969. And this was during the administration of a governor not generally believed to be very well-disposed to increased spending, and certainly not on higher education. In the process, and with the generosity of alumni and friends of the College and the fervent support of the Board, Anderson increased the College's support from its own funds to more than $\$ 1,000,000$ per year for the past three years. In 1976-77, the total budget of the College was just short of $\$ 5.5$ million composed of state money, College-generated money including endowment income, and federal student-aid funds. This growth in financing the operation of the College has. been phenomenal. It was the accomplishment of a very practical and persuasive administrator, who could point out to Sacramento that Hastings spends less to educate a lawyer than any of the other law schools of the University of California.

Under Anderson, Hastings has finally evolved an adequate administrative structure. Nothing over the history of the College hampered the opportunity to plan and to execute plan more than the absence of sufficient officers charged with specific responsibilities. From Slack to Sammis, the dean was torn between fragmented duties, delegation was largely ad hoc, and the administration found itself without contingency preparations and consequently subject to grabbing at expedients to meet problems that could have been better handled by established procedures. Had such procedures existed, the problems might well not have arisen. A vice-dean is responsible for curriculum and also exercises a roving commission as well as serving as secretary to the faculty. Three associate deans, each with a 
defined departmental responsibility, handle administration, development, and student affairs, respectively. Legal matters are the responsibility of the general counsel, who is also registrar and secretary to the Board. There is provision for special assistants to serve the dean on an ad hoc basis for particular functions. The librarian and three directors for special curricula (clinical programs, moot court, legal writing and research) exercise departmental responsibility. All these officers report to the dean, have ready access to him, and join with him in an informal council which provides routine administrative coordination. Increasingly, the dean's functions are policy and planning-not administering. With 1500 students, over 50 full-time and nearly 30 part-time faculty, and a further 25 temporary part-time instructors in legal writing and research, departmentalization provides administrative oversight that would be otherwise impossible. The dean is afforded time to maintain and advance the College's relationship with alumni, legislators, the bar, and the academic profession and other law schools. The dean can keep the Board of Directors fully informed and genuinely involved in the development of the College. Bureaucracy has become a dirty word in our vocabulary. If bureaucracy is sometimes soiled by excess, the absence of sufficient sophisticated bureaucracy does not make for purity, only for muddiness.

The evolution of an efficient and self-sufficient administrative structure has served another end. No longer is Hastings dependent, as it had been during much of Snodgrass' tenure, on the University's assistance and expertise. This has reinforced the College's autonomy. By making David a little more Goliath's peer, a certain deterrent has been built into the armory that once was only a slingshot. That is not to intimate that since the passing of the two old warriors of the 1940s50 s, the relationship between Hastings and the University has been other than proper and harmonious. President Clark Kerr was far too occupied in the early years 
of his administration with establishing more campuses of the University to concern himself with Hastings, and too occupied in the later years with the student troubles and the fight for the survival of the existing University. His successor, Charles J. Hitch, coming from outside the University and the state, did not have the incubus of the past bearing down upon him. Hitch's relations with Sammis and Anderson were genuinely amicable, and the administrations of both the University and Hastings found themselves allied in the wearing and wearying defense of higher education in the face of Governor Ronald Reagan's distrust of the University and his policy of economization. Both the University's attempt to establish a new law school on the Santa Barbara campus and Hastings' proposal to open a branch in San Diego were downed by the chill from the governor's mansion in the early 1970s. Recently, Hastings has established joint-degree programs with two schools on the Berkeley campus, ${ }^{15}$ and health facilities for Hastings students are provided by UC San Francisco. The common-law marriage is in a period of tranquility and mutual respectwith even a touch of affection gracing the entente cordiale.

Not all was accomplished by the current dean alone, but much of it was planned by him and all of it was spurred to accomplishment by him. Anderson has sought to open Hastings to new influences and to bring it to a heightened sense of purpose. He has strengthened faculty autonomy and expanded the faculty's role in hiring and tenure decisions. To bring town and gown closer together, the College now has a board of visitors composed of alumni, civic leaders, educators, businessmen, and lawyers who represent the outside world to students and staff, and who, by witnessing the routine operation of the College, interpret it to the communityat-large. The Alumni Association has been strengthened and its support solicited for more than merely its members' checkbooks. The Hastings Community, the alumni magazine, and a frequently issued directory of 
alumni tie the current College family to its past members in a bond of respect and affection based upon knowledge of Hastings today, not on fading memories of Hastings yesterday. Through the endowment-raising activities of the 1066 Foundation, the College's alumni, staff, and friends are afforded an opportunity to contribute to the growth of Hastings in the years to come. And there is now the UC Hastings Law Center Foundation, dedicated to the monumental task of raising some $\$ 15$ million to give Hastings the facilities for its next century.

Since the late 1960s, the College has had available to it the old Bancroft-Whitney plant across Hyde Street. Since 1971, the College's dean and its Board have envisioned a use for that site which will give Hastings the finest physical facilities of any law school in the West, and a match for those anywhere else in this hemisphere. There has been something expansionist about the spirit of Hastings College of the Law since David Ellington Snodgrass dreamt his dreams of a permanent building for the College and plotted a midnight requisition of old McGeorge in Sacramento during the hard years of World War II. In fact, there was something expansionist about Hastings from the beginning-if Serranus Clinton Hastings didn't think of buildings for expansion, he did think of program expansion. The new law center planned for the Civic Center across Hyde Street from the present building is not to be just another structure to take off the pressure on existing facilities. It will be the vehicle for setting on foot the most ambitious program the College has undertaken since the Founder's creation of the University's "law department."

The outline of that program is already a reality. Since 1971, Hastings' College of Advocacy, by offering workshops and expert instruction, has provided an opportunity for practitioners from all 50 states, American territories, and foreign countries to hone forensic skills and broaden their horizons as advocates. What is now primarily a summer program, latterly involving both 
civil and criminal practice at both trial and appellate levels, has the potential for becoming a year-round program once the new law center's facilities are available. Already, the Western Regional Office of the National Center for State Courts, funded by the federal government and directed at studying ways to improve the administration of justice in a period when the ideal of justice has never been more highly desired and more elusive of attainment, is associated with Hastings. Further expansion of the National Center's work in the West depends upon better facilities available on a regular basis. The planned courtroom facilities in Hastings' new center, with ample office and support space, will enable the College to make a contribution to legal development that it cannot now make. The Hastings Service Foundation, which maintains and operates the bookstore, Hastings Research Services, a non-profit corporation that affords students and graduates an opportunity to undertake part-time legal work with a practical research dimension, and the clinical programs are now working out of nooks and crannies, dependent upon the largesse of others. The center will provide them with good housing. New library facilities, requisite to house double the collection that the College now has, and which will be demanded by a vital research and scholarly emphasis in the law school of the future, will find a home in the center. Indeed, this book itself is a harbinger of that new emphasis, the first publication of the Hastings College of the Law Press, a candle from the past to light a path in the future for a succession of scholarly monographs on the law. Other programs, some scholarly, some instructional, some practice-oriented, all related to legal needs and concerns, some of which we are already familiar with, some of which we do not yet perceive, will make the new law center a laboratory for the law to be, not an oratory to the law that was. The law school, like its parent the university, must remain a castle rather than a cathedral.

The new beginnings are meant to enhance, not 
diminish, the century-old traditional function of Hastings: the education of lawyers. For all the many mutations that American law has undergone in the two centuries of our national experience, its purpose remains the same. Law is to do justice, maintain public order, preserve rights, and advance the commonweal. Implicit in justice, order, and rights, explicit in the advancement of the commonweal, is the idea that the law changes. The essence of legal education remains: it is the preparation of lawyers to work necessary change in the law and to know what is the commonweal. The vision of the new law center, as evoked by the man who conceived it, Marvin J. Anderson, fits that objective:

If legal institutions are to continue to be effective in their expanding role within our rapidly changing society, then our law schools must seek revitalization and innovation. Now is the time to act for the society of the year 2000 .

Hastings College of the Law has an unprecedented opportunity to create a truly significant Law Center which will combine the resources of a great national law school with those of the organized bar and the broader civic and business communities-dedicated to provide superior legal talent to the profession while working for meaningful change in society under the rule of law. ${ }^{16}$

We lack the ear for the elegant high-flown rhetoric of Serranus Clinton Hastings at Berkeley on June 5, 1878, when he announced the foundation of Hastings College of the Law. Allegory is too frail for our hardbitten expressions of reality in a technological world. Yet Anderson's matter-of-fact statement catches the echo of that earlier address:

This institution is intended to supply a substitute for the Inns of Court, the historic Inner Temple, a temple of the law, which shall extend its arms and draw within its portals all who shall be worthy to worship at its shrine, resulting in the coronation of its votaries, as a reward for application, industry and merit. ${ }^{17}$ 


\section{Epilogue}

Serranus Cllinton Hastings and his contemporaries entertained no doubts about the value and the validity of history. For them, history taught lessons, and practical ones at that. A statesman ignorant of history was innocent of statecraft. He might be the helmsman of the ship-of-state, but he would not be a navigator. History was also the key to understanding the inimitable and even ineffable "spirit" of a people, a "race." The towering philosopher of nineteenth century German metaphysics, G.W.F. Hegel, had posited the working of Geist, or spirit, as a process in history over time. For Hastings' generation, the worlds of the mind and of society seemed dominated by two of Hegel's wayward intellectual "children," both of whom were probably familiar to Hastings, if for no other reason than that the German universities which he visited in the 1870s were charged with their notions. Karl Marx had rejected Hegel's Geist and substituted for it materialism, but a materialism that was a process in history over time, obeying the same laws of dialecticism as Hegel's Geist. Hastings would never have approved of Marx. Neither would he have found Heinrich von Treitschke much more palatable; Treitschke's exaltation of the German Volkgeist, the spirit of the German race, would not have sat well with one so eminently Anglo-Saxon as Hastings. Yet, Hastings understood the appeal of "spirit," and abhorred: 
a growing tendency ... to neglect the study of history of the law and its traditions, without the knowledge of which the student can never become imbued with the true spirit of jurisprudence. ${ }^{1}$

Hastings would have appreciated the careful scholarship of the most eminent German historian of the day, Leopold von Ranke, a "scientific" historian who shunned subjectivism without tumbling into positivism. And Hastings' Catholicism would have made him open to the appeal of John Lord Acton, who reminded his generation that "History compels us to fasten on abiding issues and rescues us from the temporary and the transient." ${ }^{2}$ Hastings' own ambition in founding the College that bears his name was to provide a hedge against the temporary and the transient. He succeeded.

We are no longer sure that history teaches anyone anything. Historical "process," whether in the manifestation of the spirit or the material, has little appeal to our age. The path pointed out by Treitschke led to the double holocausts of Verdun and Auschwitz, and the Marxists have found it simpler to jettison the Teacher's history than to attempt to make it fit the evidence that tells against it. Perhaps Acton has best stood the test of time and the trammels of technology-the "abiding issues" do indeed abide, thanks to an innate human sense that such issues exist, and thanks to historians who, while they tell us more and more about less and less, still assume that the past has meaning and that history has some other purpose than to entertain.

The "abiding issues" of Hastings' first century might easily be overlooked in the sometimes dramatic, always engaging events of its past. That would be a pity, because Hastings has enjoyed a remarkable continuity in its institutional development. For all the struggles, despite the setbacks, regardless of weaknesses, and notwithstanding often limited resources, the College has maintained its purpose, its constituency, its contribution to society, and its integrity.

From the beginning the College's purpose has been 
to train lawyers. This it has never failed to do. It has prepared more men and women to practice law than any other law school in California, and this has been its almost exclusive function. Unlike a number of other major law schools, it has not sought to train academic lawyers-it still eschews a graduate law program. It has never aspired to being a school of "jurisprudence," not even in the middle years of the first half of the twentieth century when a number of law schools accepted a broadly-based jurisprudential emphasis as the mark of distinction in academic law. While its curriculum and programs, especially during the past two decades, have been expanded and modernized, the thrust of the changes has been towards practicality and practice. Hastings has always avoided pedagogical frills (going so far, sometimes, as to avoid apparent frills which would have added measurably to its program), and the observation in 1935 of Monroe Deutsch, vice-president of the University of California, that the Directors of Hastings were more interested in substance than in form in the matter of legal education ${ }^{3}$ has been true throughout the College's history.

Hastings has remained loyal to its constituency. Above all, it has remained loyal to its students. From the outset, it sought to train anyone possessing the qualities of intellect and character requisite to a lawyer, without respect to social status or wealth, to the limits of the College's facilities. Serranus Clinton Hastings made clear the College's policy on this point:

the founder (and he hopes his descendants) will look upon the rejection of any applicant or student on account of his poverty or limited means of support, as a calamity subversive of the object of the foundation. ${ }^{4}$

It required Clara Shortridge Foltz and Laura De Force Gordon to make explicit that "student" included women, but it has welcomed women aspirants since. Today, in its recruitment of women and minorities Hastings has gone further than most law schools in this country and 
at least as far as any other. Hastings has also remained true to its greater community. It has always drawn the bulk of its students from the San Francisco Bay Area. It has maintained close relations with the legal profession in the Bay Area and the state. It has refused to move away from its traditional bailiwick of downtown San Francisco, and it remains committed to the urban environment, to the inner-city, to the cause of the metropolitan area in an era when very little is to be gained educationally by proximity to the courts and when other institutions and individuals have been fleeing to exurban areas. This purposefulness and solidity is maintained at the expense of many of the amenities which traditional academic life values.

Hastings' contributions have been primarily to the practicing bar and to the judiciary drawn from the bar, secondarily to California political life in elected, appointed, and civil-service officials. This was true from the earliest graduates (from the Class of '82) and it remains true today. In a profound way, Hastings College of the Law is a "service institution," contributing its sons and daughters to the legal and political system which continues to be the instrument for change, the forum for civic life, and the vehicle for human aspirations, personal and collective, for a better life in a better society.

Hastings College of the Law, though it remains "the law department of the University of California," has not been for three-quarters of a century the only law school of the University. Nevertheless, it contributes to the greatness of that great University by rounding out its structure for legal education. The College has had to struggle to retain its autonomy-its integrity. A succession of deans and generations of Directors have had to avoid the embrace of an institution which has grown enormously over the years, of a university the units of which have become excellent while losing their inimitable individual characters. Hastings has managed to become excellent while retaining its individuality and dis- 
tinctive institutional character. Without its own Board of Directors and without the privileged position afforded it by the 1878 act, Hastings long since would have been swallowed up by the behemoth University. The price paid for autonomy has been Hastings' isolation from the cross-fertilization of a larger university community. The cost was less than an academic would usually be prepared to credit: law schools everywhere have tended to be rather more isolated from other university units than any other professional school, and the 65 Club gave to Hastings at a critical moment in its growth a faculty that had been as throughly involved in a broad nexus of interdepartmental influences as any law professors anywhere. The gain has been great. Hastings has been enabled to retain its principal purpose undeterred by blandishments to do something else because current academic ideology dictates it be done. Because of its isolation, Hasting has been able to remain faithful to its constituency-to its students by a more immediate contact between the policymakers at the top and the recipients of education at the bottom, to its metropolitan community by the intimate connection between the College and the bench and bar. The College remains graspable as an institutional entity-the dean is available and the dean can act with finality. No other unit of the University of California (assuming that Hastings is such a unit) has been in a position to deal so directly with students and community since Robert Gordon Sproul transformed the presidency of one campus into an imperium over many. Hastings remains open to direct influences from outside. There is no filtering process between the outside and the law school, no statewide administration either to absorb external pressure or to impose its own interpretation of external reality. The perils of openness are more than offset by the benefits. The direct links between Hastings and the legal and political life of California make the College and its students aware of external realities and sensitive to societal concerns. 
This Actonian analysis does not quite do justice to the historic Hastings. Perhaps there is something to be said for Hegelian "spirit" in evoking an institution's past. Hastings' Geist-its unique and inimitable quality-is a compound of its adherence to traditional educational and professional values and its determination to adapt to new circumstances. From the outset, it has sought to make "learned" lawyers capable of dealing intelligently, discerningly, and knowledgeably with legal problems. In these pages, the educational activities of the College have received major attention. Overlooked has been what the College demanded of its postulants in terms of character. Probity has been a constant refrain from the beginning, even though about 1950 the requirement for an applicant to present evidence of good moral character was dropped from the announcement, and a course in legal ethics, so devoutly desired by the Founder, has appeared, disappeared, reappeared, and disappeared again. Good character was a constant refrain even when such an eminent graduate as Abe Ruef, '86, ended up in San Quentin for corruption and a number of others of its alumni found themselves afoul of the law and professional standards of propriety. With probity goes civility, and civility in turn evidences professional commitment. Over the course of a century, Hastings' alumni have manifested as students and practitioners a high level of good behavior and professionalism. The College has demanded no less professionalism of itself. With its eye fixed on the needs of the legal profession, the College has sought to provide the best education for the practitioner. In its early years, this was the Pomeroy System; in its middle years, the detailed curriculum of traditional subjects conveyed by the Langdell/Ames method; latterly, the problemorientation taking account of broader concerns and contemporary social context. The professors have gladly taught and the students gladly learned, whether there was a sole Professor, a staff composed almost en- 
tirely of part-time practitioners, a faculty of eminent retired professors from other law schools, or a faculty composed (as it is today) of retirees, younger full-time, and part-time professors. No matter how poor-or how rich-the College has adapted to changing needs in legal education by its commitment to educating practicing lawyers, and it has been prepared to do the unusual in providing that education. It has eschewed trendiness while welcoming novelty. Hastings' Geist has been the spirit to stand firm but not pat.

Historians make poor prophets-their eyes are too firmly fixed on the past to afford them much prospect of the future-and they should be without honor as prophets everywhere. Yet there is merit in applying to institutions what earlier was directed at the College's early graduates:

Youth, what man's age is like to be doth show;

We may our ends by our beginnings know. ${ }^{5}$

Hastings' youth is over; its maturity begins. It is now a major, national, American law school, in curriculum, admissions standards, and quality of faculty hardly distinguishable from the other dozen or so sisterinstitutions which inhabit those empyrean heights of legal academe. It carries with it the affection and the loyalty of the thousands it has made learned in the law. It goes forth with the respect of the community of which it is a part and which it has served for a century. Hastings' "youth" was turbulent and productive. Given its first century, it is unlikely that the second will be any less challenging, any less dramatic, any less creative. It only remains to be seen what the challenges will be, how the drama will unfold, what new paths creativity will take. Here the historian would have to turn prophet, and that he would not be. But the present makes clear that the abiding issues remain, the spirit is undiminished. Hastings will remain unique, inimitable in its next century as it was in its first. 


\section{Notes}

The following abbreviations are used throughout:

CU-1 University of California Archives, Berkeley, Regents' Papers.

CU-5 University of California Archives, Berkeley, President's Papers.

M.B. Hastings College of the Law Archives, Minute Book of Board of Directors.

Sammis Pprs. Hastings College of the Law Archives, Papers of A.M. Sammis.

Snodgrass Pprs. Hastings College of the Law Archives, Papers of D.E. Snodgrass.

Citations to law reports and statutes follow accepted legal citation.

\section{Prologue}

1. The Foundation Statutes of Bishop Fox for Corpus Christi College, G.R.M. Ward ed. (London, 1843) 2.

2. S.E. Morison, The Founding of Harvard College (Cambridge, Mass., 1935) 3, quoting New Englands First Fruits (1643).

3. The Book of the General Lawes and Libertyes, T.G. Barnes ed. (San Marino, 1975) 5-6.

4. G. Barth, Instant Cities: Urbanization and the Rise of San Francisco and Denver (New York, 1975) xxiii-xxiv.

\section{Chapter I} 131.

1. Register of the University of California, 1878-9 (Berkeley, 1878) 8 \&

2. Address of S.C. Hastings, Founder of Hastings' Law Department of the University of California, before the Regents, President and Faculty (San Francisco, 1878) 5.

3. Ibid. 15 . 
4. Ibid. 18-19.

5. Ibid. 20; Hastings spoke of "communism, mobs and other disorders ..." in his speech, 6 .

6. Ibid. 20.

7. MB, I, 23-24.

8. CU-1, 5 (H1878), from Sonoma, Aug. 22, 1878.

9. O.T. Shuck, History of the Bench and Bar in California (Los Angeles, 1901) 371-72. L.C. Powell, Philosopher Pickett, the Life and Writings of Charles Edward Pickett, Esq., of Virginia (Berkeley, 1942) is a lively biography recounting Pickett's exploits.

10. Shuck, 455.

11. 1 Cal. 295, at 312 .

12. C. Kasch, "The Yokayo Rancheria," California Historical Quarterly, 26 (1947) 209-15; People v. S.C. Hastings, John Currey and the Tract, 34 Cal. 571 (1868) and brief in the same, ex parte defendants [Bancroft Lib., 868.M5.M2].

13. Calif. State Archives: GP1:236, Dr 575; Dr 4718 (Loose letters, 1850-56).

14. Calif. State Archives: Dr 4718, Hastings, Atty. Gen., to W.S. Pierce, state comptroller, Feb. 4, 1852.

15. 1 Cal. 455 , at 458 (1851).

16. 1 Cal. 333 (1850).

17. 1 Cal. 338 (1850).

18. 1 Cal. 406 , at 408 (1851).

19. 1 Cal. 76 , at 84 (1850).

20. Payne v. Pacific Mail Steamship Co., 1 Cal. 34, at 37 (1850) and Payne v. Jacobs et al., 1 Cal. 39, at 41 (1850); Persse et al. v. Cole, 1 Cal. 369, at 370 (1851); Innis v. the Steamer Senator, 1 Cal. 459, at 459 (1851).

21. People v. Daniels, 1 Cal. 107, at 107 (1850); compare Acquital et al. v. Crowell et al., 1 Cal. 191, at 193 (1850), verdict against evidence.

22. Luther $v$. Master $\mathcal{E}^{\circ}$ Owners of the Apollo, 1 Cal. 15, at 17 (1850), with Bennett, J., dissenting.

23. 1 Cal. 32, at 33 (1850); compare Gunter v. Sanchez et al., 1 Cal. 45 (1850), dissent of Hastings, C.J.

24. 1 Cal. vii.

25. The court would have used one of the early editions of the Diccionario: Valencia (Spain) 1838, or the reimpression Caracas (Venezuela) 1848 , or Mexico City 1842. Conceivably, the justices might have had in hand a translation of it in English, published in 1840 as Elements of Spanish Law-but the references in the Reports are to the Spanish title. The Diccionario had a long run, into this century, especially in Mexico, as "Escriche Mexicano." Escriche y Martin, though a Madrid magistrate, was anti-colonial and anti-clerical, which recommended him to Spain's excolonies in the New World; see Escriche y Martin, Manual del Abogado Americano (Paris, 1856) Prólogo, praising the Latin American peoples for having thrown off the yoke of political and religious despotism. The Manual was a handbook of procedure and forensics, as well as of business practices, fees, etc., for lawyers in Latin America.

26. Ladd v. Stevenson, 1 Cal. 18, at 23 (1850).

27. 1 Cal. 255, at 287 (1850).

28. 1 Cal. 295, at 322 (1850). A good, brief resumé of the San Fran- 
cisco pueblo lands snarl is available (in of all places) Appendix to the Journals of the Senate and Assembly, 17th Session, 3 (Sacramento, 1868) report of the Assembly's judiciary committee. The conclusions reached by the committee should be treated with caution.

29. 1 Cal. 98, at 100, 101 (1850).

30. 1 Cal. 413 (1851).

31. 1 Cal. 462, at 468 (1851), opinions of Hastings, C.J., \& Bennett, J.

32. Calif. State Archives: Dr 4718, Hastings, Atty. Gen., to Assembly, March 21, 1853.

33. Annual Address by S. Clinton Hastings (San Francisco, 1879) 13.

\section{Chapter II}

1. The Blue E Gold (Junior Class, 1886) 125.

2. MB, I, 25.

3. Register of the University of California, 1878-9 (Berkeley, 1878) 132.

4. $\mathrm{MB}, \mathrm{I}, 31$.

5. Huntington Library: Alice Park Collection (box 3) C.S. Foltz to A. Park, Dec. 18, 1925-I owe this information to Prof. Gary Ostrower.

6. M.D. Schwartz, S.L. Brandt, \& P. Milrod, "Clara Shortridge Foltz: Pioneer in the Law," Hastings Law Journal, 27 (1976) 559.

7. Ibid. 553.

8. Foltz v. Hoge et al., 54 Cal. 28 (1879).

9. Ibid. at 33 .

10. Shuck, 831 .

11. Bancroft Library: Keith Papers, CB595 (carton 3) certificate by John LeConte, Sept. 15, 1879.

12. Bancroft Library: Keith Papers, CB595 (carton 3) "The Origin and History of Wills."

13. Bancroft Library: Keith Papers, CB595 (carton 3) tributes to Mary McHenry Keith.

14. Bancroft Library: Keith Papers, CB595 (carton 3) tribute to M.M. Keith by Wells Drury, from The Courier, Dec. 2, 1911.

15. W.W. Ferrier, Origin and Development of the University of California (Berkeley, 1930) 602.

16. Annual Address by S. Clinton Hastings (San Francisco, 1879) 1-16.

17. Address of S.C. Hastings (San Francisco, 1878) 7.

18. From J.H. Newman, Discourses on University Education (1852) printed in The Universities in the Nineteenth Century, M. Sanderson ed. (London, 1975) 125.

19. Annual Address by S. Clinton Hastings, 14.

20. Cal. Stats. (1867-8) ch. 244.

21. Cal. Stats. $(1877-8)$ ch. 351.

22. CU-5, 954 (101) (1957-8).

23. V.A. Stadtman, The University of California, 1868-1968 (New York, 1970) 132.

24. MB, I, 36 .

25. MB, I, 36.

26. MB, I, 42, Board meeting, March 26, 1881. 
27. MB, I, 53-55.

28. 17 Vesey 491 .

29. MB, I, 50-52. 1885.

30. Cal. Stats. (1885) ch. 157, signed by the Governor, March 18,

31. 69 Cal. 215 (1886).

32. MB, I, 59, Board meeting April 1, 1886.

33. Golden Jubilee Book, 1878-1928, Hastings College of the Law of the University of California, 11.

\section{Chapter III}

1. J.W. Hurst, The Growth of American Law: The Law Makers (Boston, 1950) 261.

2. Quoted in A.E. Sutherland, The Law at Harvard (Cambridge, Mass., 1967) 175; see also, A Selection of Cases on the Law of Contracts, C.C. Langdell ed., 2d ed. (Boston, 1879) viii-ix, preface to 1 st edition. 1881) 103 .

3. J.N. Pomeroy, A Treatise on Equity Jurisprudence, 1 (San Francisco,

4. P.S. Paludan, "John Norton Pomeroy, State Rights Nationalist," American Journal of Legal History, 12 (1968) 275-93.

5. J.N. Pomeroy, An Introduction to Municipal Law, 2d ed. (San Francisco, 1883) xiii, preface to 1st edition.

6. Pomeroy, Equity Jurisprudence, 1, vii.

7. Ibid. vii.

8. Railroad Tax Cases: 13 F. 722 (1882) and 18 F. 385 (1883). Debris Case: 16 F. 25 (1883) and 18 F. 753 (1884).

9. Great American Lawyers, W.D. Lewis ed., 8 (Philadelphia, 1909) 119 , n.43, from sketch of Pomeroy's life by his son, J.N. Pomeroy, Jr.

10. Pomeroy, Municipal Law, xvi.

11. G. Gilmore, The Ages of American Law (New Haven, 1977) 47.

12. Ibid. 42.

13. Quoted in P.C. Jessup, Elihu Root, 1 (New York, 1938) 62.

14. Golden Jubilee Book, 1878-1928, 41.

15. C.W. Slack, "Hastings College of the Law," The Green Bag, 1 (1889) 522.

16. Bancroft Library: Keith Papers, CB595 (carton 3) papers on M.M. Keith's education, examination for senior class, 1882, on Constitutional Law.

17. Great American Lawyers, 8, 135.

18. Slack, "Hastings College of the Law," 524.

19. MB, I, 61, Board meeting, May 24, 1886.

20. Register of the University of California, 1878-9 (Berkeley, 1878) 134.

21. Golden Jubilee Book, 1878-1928, 39.

22. Slack, "Hastings College of the Law," 523.

23. MB, I, 102, Board meeting, June 6, 1890.

24. Slack, "Hastings College of the Law," 524.

25. Ibid. 521 .

26. W.H. Platt, After Death-What? Or, Hell and Salvation Considered in the Light of Science and Philosophy, 2d ed. (San Francisco, 1878)-some 200 
pages of rhetorical pyrotechnics with negligible substance; also, two sermon-pamphlets, "Hell and Salvation Rationally Considered" (San Francisco, 1878) [Banc. F855.5.P55 x] and "Inspiration. An Imaginary Symposium between Col. Ingersoll and a Lawyer" (San Francisco, 1882) [Banc. F857.P217 v. $4: 17 \mathrm{x}]$.

\section{Chapter IV}

1. MB, I, 191-92.

2. $\mathrm{MB}, \mathrm{I}, 195$.

3. Moods, and Other Verses (San Francisco, 1899) and Visions, and Other Verse (San Francisco, 1903) were at least better lyric poetry than his later work, such as "On the Death of Mark Twain," about 1910:

His waves of laughter rolled around the world, And ever shall though he be dead;

In vain the conqueror Death has madly hurled

His spear against that noble head,

For drowned in mirth immortal, he,

Despairing, yields the victory.

This is from K.M. Johnson's helpful biography, The Life E' Times of Edward Robeson Taylor (San Francisco, 1968) 51. Two later anthologies of Taylor's, To Arms (San Francisco, 1917) and Chants With the Soul (San Francisco, 1920) evidence considerable decline and strike a sad note of imminent mortality.

4. From Progress and Poverty, as quoted in K.M. Johnson, "Progress and Poverty - Paradox," Calif. Hist. Qtly, 42 (1963) 31; Johnson provides a sensitive picture of George's and Taylor's relationship.

5. Shuck, 1067. W. Bean, Boss Ruef's San Francisco (Berkeley, 1967) supplies most of the information here on the scandal and Taylor's role in reform.

6. Golden Jubilee Book, 1878-1928, 48.

7. Ibid. 49 .

8. Johnson, Edward Robeson Taylor, 55.

9. Gustav Gutsch, "Legal Education in the State University," in Shuck, 223.

10. MB, I, 240.

11. Adolph Sutro's Letter to the Regents . . . and to the Committee of Affiliated Colleges on the Selection of a Site for the Affiliated Colleges [San Francisco, 1895] [Banc. Z733.C153.S9] 3.

12. The UC librarian provided a survey of periodical literature in various California libraries, including the San Francisco Law Library, in 1880, published in Appendix to the Journals of the Senate and Assembly, 24th Session, 3 (Sacramento, 1881) "University of California. Library Bulletin, No. 1."

13. MB, I, 204.

14. MB, I, 216, Board meeting Nov. 28, 1902.

15. Ferrier, 489.

16. MB, I, 249, minority report by C.W. Slack, May 27, 1910; incidentally, this is the earliest typewritten document to appear in the Board's Minute Book. 
17. 110 P. 341 (1910). Justice A.F. Bray, Jr., '10, a member of the Class admitted in this case, has supplied considerable information about this episode not in the report or otherwise available.

18. 110 P. 341 , at 342 (1910).

19. MB, I, 270, Board meeting April 25, 1913.

20. From the course descriptions in the Announcement of the College during Taylor's years, it is evident that he regularly made reference to Story's Equity Jurisprudence as well. Before using Scott, Taylor used Keener's Casebook on Equity Jurisdiction. Keener was an early disciple of Langdell, and his casebook was as stiff and crowded as Langdell's on Contracts; Scott reflected the trimmer casebook of the type Ames pioneered. James A. Ballentine noted that Taylor was a slow convert to the full Langdell/Ames case method, and that even after he adopted the casebook, Taylor assigned much textbook reading, coming only gradually to diminish textbook work and to embrace the casebook as "the best foundation for a knowledge of the law," Golden Jubilee Book, 1878-1928, 48.

21. MB, I, 209, Board meeting July 26, 1901, letter from E.R. Taylor, June $19,1901$.

22. Ballentine's Law Dictionary, W.S. Anderson ed., 3d ed. (Rochester and San Francisco, 1969). The 1st ed., 1930, contained a foreword by Dean Roscoe Pound of Harvard.

23. Gilmore, The Ages of American Law, 68-74.

\section{Chapter V}

1. The foreword noted: "Few professional schools, especially in the West, can boast of this ripe old age. Mere age is not a just cause for celebration, however, for age without accomplishment is rather an occasion for regret. The students, the alumni, the faculty, the directors, and all friends of the institution contemplate the record of this school and its graduates during the last half-century with a feeling of pride, and know that there is just cause for the celebration of this Golden Jubilee."

2. California Law Review, 10 (1922) 185-201.

3. Golden Jubilee Book, 1878-1928, 27.

4. J.G. Bates, History of the Bench and Bar of California (San Francisco, 1912).

5. Inkersley's and Daw-Kerrell's kalendar is in Banc. f F855.7 A6 $1898 \mathrm{x}$.

6. W. Bean, Boss Ruef's San Francisco, provides most of the information for this sketch of Heney.

7. T.G. Paterson, "California Progressives and Foreign Policy," Calif. Hist. Qtly, 47 (1968) 336.

8. H.R. Jones, John Muir and the Sierra Club: The Battle for Yosemite (San Francisco, 1965) 79; this book is dedicated to Colby's memory. See also an appreciation of Colby as teacher and scholar by O.K. McMurray, Calif. Law Review, 25 (1936-7) 293.

9. 13 F. 722 (1882) and 18 F. 385 (1883).

10. Hurst, 303.

11. K.M. Johnson, The Bar Association of San Francisco: The First Hundred Years, 1872/1972 (San Francisco, 1972) 24. 
12. MB, I, 313, Board meeting Feb. 25, 1921.

13. Golden Jubilee Book, 1878-1928, 59.

14. Letter, Hazel Utz Lancaster to author, May 4, 1977.

15. Sir John Denham (1615-1669) Of Prudence; Denham was the son of an eminent English judge.

\section{Chapter VI}

1. MB, I, 408, Board meeting July 31, 1940.

2. H.S. Pritchett to MIT alumni, 1904, quoted in F.E. Wylie, M.I.T. in Perspective (Boston, 1975) 41.

3. A. Flexner, Medical Education in the United States and Canada, Carnegie Foundation for the Advancement of Teaching Bul. 4 (New York, 1910).

4. A.Z. Reed, Recent Progress in Legal Education, U.S. Dept. of the Interior, Bur. of Education, Bul. 1926, 4 (Washington, 1926) 11.

5. Ibid. 11.

6. A.Z. Reed, Training for the Public Profession of the Law: Historical Development and Principal Contemporary Problems of Legal Education in the United States, Carnegie Fdn. Adv. Tchg Bul. 15 (New York, 1921) 3.

7. Ibid. 414-16.

8. Ibid. 418.

9. The committee were: Henry Wade Rogers, dean of Yale until 1913, when he became a judge of U.S. 2nd. Circuit Court; Lawrence Maxwell, professor at Cincinnati; Roscoe Pound, professor at Harvard, and dean from 1916; William Draper Lewis, dean of Pennsylvania; Selden P. Spencer, in practice in St. Louis. Lewis was the prime mover of the project.

10. Quoted in Preble Stolz, "Training for the Public Profession of the Law (1921): A Contemporary Review," Training for the Public Professions of the Law: 1971, Report to AALS (Washington, 1971) 164. I am grateful to Prof. Stolz for reading and criticizing this chapter. He points outrightly - that Flexner started with his conclusions and summoned the facts to support them in the report on medical education, whereas Reed started from the facts and then reached his conclusions. I accept that this was the fundamental difference between the men and their respective reports; we agree that Flexner succeeded and Reed failed, though Stolz sees the failure as less foreordained than I argue it was.

11. Ibid. 155-56.

12. Ibid. 165 .

13. A.L. Corbin, "Democracy and Education for the Bar," Handbook of the AALS E Proceedings of the 19th Annual Meeting [1921].

14. A.Z. Reed, Present-Day Law Schools in the United States and Canada, Carnegie Fdn. Adv. Tchg Bul. 21 (New York, 1928) 400.

15. Ibid. 85 .

16. Ibid. 86-87.

17. CU-5, 193 [1926] Reed draft.

18. Ibid. O.K. McMurray to W.W. Campbell, June 4, 1926.

19. Ibid. note by Campbell's secretary of McEnerney's reaction.

20. Ibid. O.K. McMurray to A.Z. Reed, June 4, 1926. 
21. Ibid. W.M. Simmons to A.Z. Reed, June 28, 1926 (5pp. singlespaced).

22. Ibid. W.W. Campbell to H.S. Pritchett, telegram, July 6, 1926.

23. Ibid. H.S. Pritchett to W.W. Campbell, July 16, 1926.

24. Proceedings of the First Annual Convention of the California Bar Association, 1910 (San Francisco, 1911) 120-22.

25. Proceedings 14th Annual Meeting of the Calif. Bar Assoc., 1923 (San Francisco, 1924) 131-38 \& 235. 1923.

26. CU-5, 158 (244-1) W.W. Campbell to M.E. Harrison, July 23,

27. Handbook of the AALS \& Proceedings of the 25th Annual Meeting [1927] 8 \& 100. I have not been able to find Powell's report.

28. J.R. Thelin, "California and the Colleges," Calif. Hist. Qtly 56 (1977) 238.

29. [W. Shafroth \& H.C. Horack] Report of the California Survey Committee 1933, 96-101.

30. See CU-5, 332 (33), 350 (33), 404 (33), various letters.

31. CU-5, 477 (33)(1939).

32. Bradway's blueprint was set forth in "The Nature of a Legal Aid Clinic," Southern California Law Review, 3 (1929-30) 173-80, and "Legal Aid Clinic as a Law School Course," Ibid. 320-32.

33. Announcement, Hastings College of the Law 1931-2, 7.

34. CU-5, 378 (33)[1935] Monroe E. Deutsch (vice-president \& provost, UC) to R.G. Sproul, Feb. 1, 1935.

35. A.B. Andrews, "A Classification of Our Law Schools," ABA Journal, 20 (1934) 487.

36. CU-5, 378 (33)[1935] A.B. Andrews to W.H. Waste et al., Jan. 16, 1935.

37. Ibid. M.E. Deutsch to R.G. Sproul, Feb. 1, 1935, and W.M. Simmons to M.E. Deutsch, March 6, 1935.

38. MB, I, 386, Board meeting Feb. 1, 1935.

39. CU-5, 404 (33)(1936) W.M. Simmons to M.E. Deutsch, Sept. 14, 1936.

40. CU-5, 429 (33)(1937) E.D. Dickinson to R.G. Sproul, Oct. 26, 1937.

41. MB, I, 400 .

\section{Chapter VII}

1. GU-5, 516 (415)(1940) A. Robb to R.G. Sproul, memo, attached to telegram to C.H. Kinnane, Aug. 22, 1940. The poison-pen attacks referred to are in this file and CU-5, 532 (45)(1941).

2. Hastings College of the Law, Class of ' 42 .

3. Advance Program of 66th Annual Meeting ABA, 1943, 215.

4. CU-5, 586 (747)(1942).

5. CU-5, 605 (444A)(1943) C. Engle to R.G. Sproul, March 5, 1943.

6. MB, I, 428.

7. CU-5, 503 (1934).

8. Snodgrass Pprs. (1950) A.M. Sammis, registrar, to D.E. Snodgrass, Nov. 15, 1950. 
9. Snodgrass Pprs. (1941-9) W.A. Seavey to D.E.S., Nov. 6, 1946.

10. [J.A. McClain, Jr., T.F. McDonald, \& S.P. Simpson] Legal Education and Admissions to the Bar in California (Los Angeles, 1949) 174.

11. CU-5, 625 (240)(1944). 1950 .

12. Snodgrass Pprs. (1950) D.E.S. to W.F. Knowland, March 29,

13. Legal Education and Admissions to the Bar in California, 171.

14. Ibid. 50.

15. This is a very old saw, and attribution to an originator is impossible. But alumni say Snodgrass said it-and Simmons before him.

16. CU-5, 1175 ("HCL, Pt.I") W.L. Prosser to R.G. Sproul, Feb. 11, 1952.

17. Legal Education and Admissions to the Bar in California, 40.

18. CU-5, 764 (49)(1950) and 1175 ("HCL, Pt.I"); Sammis Pprs. (Desk 3) contain a great deal of material on this matter. 1950.

19. CU-5, 1175 ("HCL, Pt.I") W.L. Prosser to R.G. Sproul, Aug. 23,

20. CU-5, 1175 ("HCL, Pt.IV") and 741 (49)(1949).

21. Assembly Bill 2292, 1949 regular session, introduced by Gordon Fleury, '39, as a blank bill on Jan. 28, 1949; CU-5, 741 (49)(1949) J.U. Calkins, Jr., to J.H. Corley, May 12, 1949. Calkins struck a plaintive note: "In my opinion the bill is unconstitutional. Furthermore, I think it is entirely out of order, inasmuch as the Academic Senate has presented a reasonable plan to take care of the complaints of the illustrious Dean of Hastings College and his students."

22. CU-5, 1175 ("HCL, Pt.IV") D.E.S. to R.G. Sproul, June 2, 1949. Snodgrass' P.S. to Sproul was, "I hope to see you at the grove." 1949.

23. The Hastings Law Journal, 1 (Fall 1949) foreword dated Nov. 14,

24. S. Sayles, "Clair Engle and His Political Development in Tehama County, 1911-1944," Calif. Hist. Qtly 54 (1975) 297-98.

25. Snodgrass Pprs. (1952) D.E.S. to L. Speiser, Oct. 14, 1952. Speiser, in replying to Snodgrass, Oct. 16, wrote, "Please do not forget that your membership in the American Civil Liberties Union is not a condition precedent [Speiser had had Contracts with Snodgrass] for our willingness to guard and protect your own civil liberties. If the occasion arises in which your freedom of speech is ever infringed upon, please don't hesitate to contact us." Snodgrass lost that round!

26. MB, I, 430. 1947.

27. CU-5, 1175 (“HCL, Pt.I”) J.H. Corley to R.G. Sproul, Jan. 4,

28. AB 1106 (Albert C. Wollenberg, George D. Collins, Jr., Bernard R. Brady, and Randall F. Dickey) introduced Jan. 28, 1947 and SB 624 (Gerald J. O'Gara, '26, Bradford S. Crittenden, '07, Thomas F. Keating, '31, and Oliver Carter, '35) introduced Jan. 28, 1947, 57th general session.

29. Cal. Stats. (1947) ch. 1530 (for Hastings) and ch. 1557 (for UCLA).

30. CU-5, 719 (49)(1948).

31. CU-5, 741 (49)(1949) minutes of meeting of building committee, March 2, 1949. Other sources for the building planning, etc., CU-5, 1175 ("HCL, Pt.I"), 764 (49)(1950), 822 (49)(1952); Snodgrass Pprs. (1941-9 
through 1953); Calif. State Archives: D 525, F 3453-14.

32. Sproul had a meeting of the Regents' building committee the day after the dedication. He'd written Vice-President Bray of the Hastings Board to this effect. Snodgrass was not satisfied, and sent a mimeographed form letter of invitation to Sproul, which Sproul's staff thought should be ignored. CU-5, 836 (49)(1953).

33. C.B. Nutting, "Training Lawyers for the Future," Hastings Law Journal, 4 (1953) 85. For an excellent description of the new building, see E.A. Hogan, "A New Home for the Oldest Law School in the West," Journal of Legal Education, 6 (1953) 226-35.

\section{Chapter VIII}

1. G.E. Osborne, "David E. Snodgrass," Hastings Law Journal, 15 (1963) 3.

2. During World War II, Snodgrass tried strenuously to get University purchasing to secure him a fluorescent desk lamp-without success, because he did not have a high enough "priority" for a scarce item, CU-5 593 (49)(1943).

3. Sutherland, 338.

4. Snodgrass Pprs. (1955), draft of review of Laurence P. Simpson, Handbook on the Law of Contracts (St. Paul, 1954), published in NYU Law Review, 30 (1955) 1135. Simpson was a professor at NYU, hence the complimentary allusion to the author's experience.

5. Snodgrass Pprs. (1941-9) D.E.S. to Louis M. Brown, April 20, 1948. The case before the supreme court, in which he was co-counsel with Orr M. Chenoweth, '07, was Associated Oil Company (Appellant) v. Harold Myers et al. (Respondent) 217 Cal. 297 (1933) involving contract for lease for sale of gas and oil by a service station; decided for the Appellant. See Snodgrass Pprs. (1957)(2) D.E.S. to Orr M. Chenoweth, June 4, 1957.

6. Snodgrass Pprs. (1941-9) D.E.S. to I.M. Shadwell, Sept. 19, 1947.

7. Snodgrass Pprs. (1963) May 12, 1963.

8. Snodgrass Pprs. (1954) D.E.S. to F.E. Gray, Oct. 27, 1954.

9. Snodgrass Pprs. (1941-9) S.F. Finley to D.E.S., Aug. 28, 1941.

10. Snodgrass Pprs. (1953) D.E.S. to A.J. Schweppe, May 11, 1953.

11. California Monthly (March 1949); the scholarship was not negligible-there are two dozen citations to case law!

12. MB, II, 17, Board meeting Jan. 17, 1950: "Resolved: That no public statement concerning the policies or the public relations of Hastings College of the Law be made or issued by its Dean, Registrar, or any members of its faculty without prior submission of such statement to and approval of it by any two (2) members of the Executive Committee of the Board of Directors." The Snodgrass torrent was not to be staunched by such porous stuff.

13. [J.A. McClain, Jr., T.F. McDonald, \& S.P. Simpson] Legal Education and Admissions to the Bar in California (Los Angeles, 1949) 93.

14. The minimum standards for ABA approval were: 3 full-time teachers (at least 1 for each 100 students); library of 10,000 volumes of current usefulness, including reports, etc.; adequate physical facilities; not operated commercially for profit; two years of college required of stu- 
dents; 3 years full-time study or 4 years of part-time study required for the LL.B.

15. Rules Regulating Admission to Practice Law in California, as amended to October 28, 1949 (Committee of Bar Examiners, 1949) 11.

16. W.L. Prosser, "Legal Education in California," Calif. Law Review, 38 (1950) 206-10.

17. Legal Education and Admissions to the Bar in Calfornia. The survey of Hastings is pp. 167-77.

18. In re Lavine, 42 P.2d.311 (1935), 2 Cal.2d.324 (1935).

19. Journal of the State Bar of California, 25 (July-Aug. 1950) 325.

20. Hastings' copy of these materials are in Sammis Pprs. (Loose) beginning with Goscoe O. Farley to D.E.S., July 10, 1950.

21. E. Cullinan, "Despite the Deans the California Accreditation Rule Should Not be Scrapped,"Journ. State Bar of Calif., 25 (March-April 1950) 163-70.

22. Crotty's position can be found in H.D. Crotty \& P. Works, "Legal Education and Admissions to the Bar in California," Journ. State Bar of Calif., 25 (Jan.-Feb. 1950) 25-36-a review of the survey report of 1949and H.D. Crotty, "Who Shall be Called to the Bar?" The Bar Examiner, 20 (July 1951) 173-99.

23. Cal. Stats. (1951) ch. 1722, signed by the Governor July 24, 1951.

24. Legal Education and Admissions to the Bar in California, 170.

25. This account of the July 21 meeting is taken from Sammis Pprs. (Loose) "Memorandum with reference to the open meeting of the Committee of Bar Examiners held on July 21," by A.M. Sammis, who was present in place of Snodgrass, and a very full report in The Los Angeles Daily Journal (the official paper of the city and county) July 28, 1950, by Elmer Cain, its editor.

26. The resolution, adopted by the Senate committee February 2, 1952, and the Bar Examiners' explanation of what happened on the October 1951 examination are in Journ. State Bar of Calif., 27 (Jan.-Feb. 1952) $16-18$ \& 26-44.

27. Journ. State Bar of Calif., 30 (July-Aug. 1953) 191; the act, amending Business and Professions Code, sect. 6060, is Cal. Stats. (1953) ch. 1090 . 1951.

28. CU-5, 1175 (“HCL, Pt.I”) W.L. Prosser to R.G. Sproul, April 9,

29. Ibid.; the only source for Hervey's visit is Prosser's letter. Hervey, who one supposes might have been favored by Prosser because of Prosser's own reservations about Hastings and Snodgrass, came out looking very bad.

30. CU-5, 1175 ("HCL, Pt.I") Richard Bentley, chairman ABA section of legal education and admissions to the bar, to D.E.S., March 1, 1951.

31. Ibid. R. Bentley to D.E.S., March 23, 1951; faculty of Hastings to R. Bentley, May 10, 1951.

32. Legal Education and Admissions to the Bar in California, 177, cited in CU-5, 1175 ("HCL, Pt.I") D.E.S. to R. Bentley, March 7, 1951.

33. Charles Beardsley, in Journ. State Bar of Calif., 28 (March-April, 1953) 74.

34. D.P. Gardner, The California Oath Controversy (Berkeley, 1967) 248-49. 
35. CU-5, 1175 ("HCL, Pt.I") E.D. Dickinson to R.G. Sproul, Aug. 27, 1940.

36. Ibid. E.D. Dickinson to R.G. Sproul, Oct. 3, 1947.

37. Ibid. J.H. Corley to R.G. Sproul, June 10, 1946. 23464.

38. Cal. Stats. (1945) ch. 1525 - it is still in the Education Code, sect.

39. Snodgrass Pprs. (1941-9) D.E.S. to L.M. Brown, April 20, 1948.

40. CU-5, 1175 ("HCL, Pt.III") A. Robb to R.G. Sproul, memo, Feb. 24, 1949. This file contains a great deal of UC internal correspondence over the Extension matter, including a number of newspaper clippings reporting Snodgrass' angry blasts towards Berkeley.

41. CU-5, 696 (49)(1947). 1947.

42. CU-5, 1175 ("HCL, Pt.I") J.H. Corley to R.G. Sproul, Aug. 28, 1949.

43. CU-5, 741 (49)(1949) E. Groff to A. Intorf, telegram, Dec. 16, 1951.

44. CU-5, 1175 ("HCL, Pt.I") J.H. Corley to R.G. Sproul, Dec. 8,

45. Ibid. R.G. Sproul to A. Robb, memo, Dec. 2, 1951.

46. CU-5, 836 (44)(1953). 1951.

47. CU-5, 1175 ("HCL, Pt.I") W.L. Prosser to R.G. Sproul, April 9,

48. W.L. Prosser \& D.E. Snodgrass, "Three Law Schools," California Monthly (March, 1949); though jointly authored, the contributions of each are apparent by their distinct rhetoric. The prolix Prosser suggested that there might be allocation of "particular specialized courses" among Boalt, UCLA, and Hastings and that the "time is obviously near when all three schools, together with the University administration and interested members of the bar, must sit down and agree upon the future."

49. Sammis Pprs. (Desk 4) D.E.S. to Board, Aug. 5, 1953, and "Report of the Faculty Committee Appointed to Consider the Policy regarding Evening Law School Instruction at Hastings."

50. CU-5, 1175 ("HCL, Pt.I").

51. Ibid. W.L. Prosser to R.G. Sproul, Feb. 11, 1952.

52. Snodgrass Pprs. (1952) D.E.S. to F.W. Links, Nov. 25, 1952.

53. Snodgrass Pprs. (1953) D.E.S. to C.L. Bradley, March 22, 1953.

54. Snodgrass Pprs. (1954) D.E.S. to K.G. McGilvray, April 13, 1954 and (1953) D.E.S. to G.A. Fleury, May 2, 1953, calling Fleury to arms.

55. CU-5, 954 (101)(1957-8).

56. CU-5, 1031 (600-30, Routine no. 1), Regents' committee on finance, Sept. 19, 1958.

57. Ibid. D.E.S. (holograph) to C. Kerr, Nov. 17, 1958. How well, by this time, Hastings was handling its own budget request is evident from a memo of the Governor's budget hearing, Oct. 16, 1959, Calif. State Archives: D 525, F3453-14.

58. CU-5, 1175 ("HCL, Pt.I") memo of R.G. Sproul, March 30, 1961, in note to A. Robb. 


\section{Chapter IX}

1. Law School Association Lyrics, W.L. Prosser ed. 45-46.

2. Radin had a worldwide reputation as the most eminent scholar of legal history, jurisprudence, and Roman Law in the United States. Snodgrass wanted to snag him along with Derby, Lorenzen, and Vold to answer the criticism-that Hastings relied too much on part-time faculty-voiced by the survey board in 1948, Legal Education and Admissions to the Bar in California, 58. Radin would not only be a full-timer, but he would also lend unusual prestige to the College and its curriculum. Snodgrass never tried star-catching again.

3. CU-5, 1031 (600-30, Routine no. 1), D.E.S. to Hastings Board, Nov. 17, 1958.

4. CU-5, 1175 ("HCL, Pt.I") deputy Atty. Gen. to D.E.S., Aug. 29, 1945, and Sammis Pprs. (Desk 2) D.E.S. to Hastings Board, Dec. 2, 1957.

5. Snodgrass Pprs. (1963) D.E.S. to B.L. Melvin, Jan. 30, 1963.

6. S.M. Ehrman, "We Declare We Will Never Retire, Until we Lose our Pep and Fire," Hastings Law Journ. 4 (1953) 88.

7. Snodgrass Pprs. (1963) R. Pound to D.E.S., Feb. 14, 1963. written.

8. Chauncey Leake died in January 1978, just as this was being

9. R.R. Powell, Compromises of Conflicting Claims: A Century of California Law, 1760 to 1860 (Dobbs Ferry, 1977). Unfortunately, this book came to hand too late for me to make use of it in the early chapters.

10. Quoted in F.H. Lawson, The Oxford Law School, 1850-1965 (Oxford, 1968) 238.

11. R.N. Sullivan, "The Professional Associations and Legal Education," Journal of Legal Education, 4 (1952) 401-26.

12. E.S. Bade, "Library Standards," Ibid. 427-30.

13. J.R. Richardson, "Is There a Place for Moot Court in the Law School Curriculum," Ibid. 431-5.

14. "On the Aims and Quality of Pre-Legal Education: An Association View?" Ibid. 441-7.

15. A.T. Vanderbilt, A Report on Prelegal Education (n.p., 1944); also, Vanderbilt, "A Report on Pre-Legal Education," NYU Law Review, 25 (1950) 199.

16. E.W. Patterson, "The Case Method in American Legal Education: Its Origins and Objectives,"Journ. of Legal Educ. 4 (1951) 1-24.

17. W.B. Harris, "New Members of the Law Teaching Profession in America," Ibid. (1952) 436-40.

18. E.N. Griswold, "Educating Lawyers for a Changing World: A Challenge to Our Law Schools," ABA Journ. 37 (Nov. 1951) 805-08. A.M. Cantrall, a West Virginia practitioner, started a buzz in the law schools with "Law Schools and the Layman: Is Legal Education Doing its Job?" $A B A$ Journ. 38 (Nov. 1952) 907-10 \& 972; in fact, the article was so tendentious and so anti-academic as to not be worth much serious consideration.

19. A.J. Harno, Legal Education in the United States (San Francisco, 1953) 185. 
20. J. Frank, Law and the Modern Mind (New York, 1930).

21. Gilmore, The Ages of American Law, 78 n.25.

22. Ibid. 82 n.36.

23. The Uniform Laws Annotated: Uniform Commercial Code presently comprises 7 volumes, 5 of them commentary.

24. 7 Rep. 18.

25. Law School Association Lyrics, 23, "The Uniform Commercial Code," by W.L. Prosser, to the tune of "My Darling Nellie Gray." In Prosser's version, it is "N.I.L." not "U.S.A.," but the author has heard it both ways.

26. American Law Institute: Consideration of Proposed Final Draft of the Uniform Commercial Code, 1950, 368-9, session of May 20, 1950. Mimeographed. The sections under discussion vis-à-vis travelers checks (6-203 to 6-207) were not in the final version of the UCC.

27. L.M. Friedman, Contract Law in America: A Social and Economic Case Study (Madison, 1965) and G. Gilmore, The Death of Contract (Columbus, 1974).

28. W.A. Keener, Selections from Leake's Elements of the Law of Contracts and Finch's Cases on Contracts, 2 vols. (New York, 1891). Boalt's copy was owned by Charles William Slack, and probably used by him in teaching Contracts at Hastings. 1894).

29. S. Williston, A Selection of Cases on the Law of Contracts (Boston,

30. A.L. Corbin, "Recent Developments in the Law of Contracts," Harvard Law Review, 50 (1937) 453.

31. E.W. Patterson \& G.W. Goble, Cases on Contracts, 3d ed. (Brooklyn, 1949); Patterson and Goble covered themselves well by dedicating the volume to both Williston and Corbin.

32. H. Shepherd, Contracts and Contract Remedies: Cases and Materials, 3d ed. (Brooklyn, 1952).

33. Calif. State Archives: D 525, F3453-14, ABA inspection report of Hastings, Dec. 10-11, 1959, by D.J. Dykstra (Univ. of Utah) and G.N. Stevens (Univ. of Washington) with J.G. Hervey, adviser-a full, balanced report, a considerable improvement over Hervey's effort of 1950.

34. These more "exotic" fields (from the practical perspective of an American law school) have been heavily represented in the $65 \mathrm{Club}$, from Orrin Kip McMurray, Max Radin (briefly), Edwin Dickinson, and Ernest Lorenzen in earlier years to Jerome Hall, Stefan Riesenfeld, Rudolf Schlesinger, and Julius Stone of late.

35. For the significance of Restatement under the auspices of the American Law Institute, see Gilmore, The Ages of American Law, 72-74.

\section{Chapter X}

1. H.E. Verrall \& A.M. Sammis, Cases and Materials on California Community Property (St. Paul, 1966). Verrall, then at USC, joined the 65 Club in 1970. 1954.

2. Sammis Pprs. (1954-5) A.M. Sammis to J.R. Merritt, May 29, 
3. Sammis Pprs. (1963) A.M. Sammis to B. Boyer, Aug. 20, 1963.

4. Sammis Pprs. (1963) A.M. Sammis to A.J. Harno, Oct. 28, 1963.

5. Sammis Pprs. (1964) J.S. Bradway to A.M. Sammis, Oct. 14, 1964, with comments on the same by Sammis.

6. Cal. Stats. (1969) ch. 797, signed by the Governor, Aug. 22, 1969, adding to Education Code new section, 23465.

7. Sammis Pprs. (1954-5) "a student" to A.M. Sammis, July 2, 1949.

8. Sammis Pprs. (1963) A.M. Sammis to A.J. Harno, Oct. 28, 1963.

9. Tabulated results of student-employment questionnaires for 1955, 1959, 1960, and 1964 are in Sammis Pprs. (Desk 1 \& Desk 3). These must be used with caution, because it was in the interest of the students questioned to underemphasize outside employment. Allowing for an error factor of as much as 20 percent, the tables still support the conclusion that there was much less outside employment than there had been before World War II.

10. Sammis Pprs. (Desk 2) D.E.S. to Board, Dec. 2, 1957. A student revolt against Saturday classes in 1956 was led by a first-year student under the appropriate pseudonym of "Thomas Paine," who raised the issue in a letter to the UC Regents. Sproul referred the matter to Hastings. CU-5, 910 (49) (1956).

11. MB, II, 42, Board meeting Jan. 20, 1953.

12. MB, II, 152, Board meeting June 21, 1968.

13. Education at Berkeley: Report of the Select Committee on Education (Berkeley, March 1966).

14. 18 Cal.3d. 34, 132 Cal.Rptr. 680, 553 P.2d. 1152 (1976).

15. The Hastings-UC Berkeley Joint Degree Program involves the School of Environmental Design (Department of Urban Planning) and School of Business Administration (J.D./M.B.A. program). Hastings students also participate in a less formal way in the Berkeley joint J.D./Ph.D. program in legal history, given by Boalt and the Department of History.

16. Quoted in brochure announcing proposed new law center, 1976.

17. Address of S.C. Hastings, 15.

\section{EPILOGUE}

1. Address of S.C. Hastings, 5.

2. John Lord Acton, Essays on Freedom and Power, G. Himmelfarb ed. (London, 1956) 26.

3. CU-5, 378 (33) [1935] M.E. Deutsch to R.G. Sproul, Feb. 1, 1935.

4. Address of S.C. Hastings, 13.

5. Sir John Denham, Of Prudence. 


\section{Bibliographical Notes}

This bibliographical note is intended to indicate the principal sources for the study of Hastings during its first century, with particular attention to material not otherwise cited in the notes to the text. It is not a comprehensive bibliography of all works consulted and used. Hopefully, it will serve to direct a reader into areas for further study, some of them beyond the bounds of Hastings proper.

\section{Archives}

Hastings College of the Law is poor in archival sources from its origins to about 1940. The early records of the College, such as they were, were destroyed in the great earthquake and fire of 1906. All that survived, and that because it was kept in one of the Director's offices not destroyed in the calamity, was the Minute Book of the Board of Directors. The first volume of the Minute Book is for 1878 to 1948; the second volume, 1948 to the present. The first Minute Book is a rich source because of the Board's involvement in much of the routine administration of the College. From the deanship of D.E. Snodgrass (1940-63), the Board was increasingly less involved with administration and more concerned with finances and policy matters; the second volume makes its contribution in these latter areas. The papers of the early deans were considered private property and were not left in the College-they have disappeared. In fact, save for business records generated in the College, including financial records and student records, there was probably little documentation created in the course of early administration. Most "running" of the College was done by word of mouth until the post World War II expansion made this impossible. I am surprised that more financial materials from 1906 to the end of Harrison's deanship, 1925, are not extant. From 1926, the College has maintained good student records, thanks to the assiduous businesslike attention of Juanita Olsson, first as dean's secretary and later as registrar from 1925 to 1946, who began an archival tradition continued by her successors. With Snodgrass, the bulk of the College's archives begins. His papers (cited as Snodgrass Pprs.) include correspondence, memoranda, newspaper and magazine clippings, and miscellaneous printed materials. Sammis' papers (cited as Sammis Pprs.) are of the same nature for his deanship, 1963-70, 
with the bonus of a considerable amount of documentation relevant to his tenure as registrar, 1947-63, under D.E. Snodgrass. The documentary sources of the present administration of Dean Marvin Anderson leave nothing to be desired-save better arrangement and a policy as to retention.

The University of California at Berkeley has a splendid archive. Because Hastings was (and is) "the law department" of the University, among both the Regents' Papers (CU-1) until about 1930 and the President's Papers (CU-5) from William Wallace Campbell's presidency in the 1920s there are virtually annual files of documents relating to Hastings. Without this material, the history of the College in its early and middle periods would be very thinly founded.

Special collections in the Bancroft Library, on the Berkeley campus, though not necessarily archives in the formal sense of the term, provide useful evidence. The papers of Mary McHenry Keith (CB595), who was the first woman graduate of Hastings, are particularly valuable for the insight they give into the Pomeroy System in the curriculum. Incidental documentation in other collections have provided additional information on Serranus Clinton Hastings and his contemporaries.

The California State Archives, Sacramento, furnish important insights into Serranus Clinton Hastings as attorney general (Dr 4718, Loose Letters, 1850-56) and some materials on the early years of the University and its "law department" (Dr 652, LP6:270). In files of the Department of Finance, there are a number of items relevant to Hastings, including the ABA visitation report of 1959 (D 525, F3453-14).

Though perhaps not archival material in the formal sense of the word, the tape-recorded oral interviews which I undertook as part of this project will be available for use in the Bicentennial History. Most of these interviews were of older alumni, some of past or present faculty and staff. All were useful. However, the shortcomings of the procedure were soon evident. Precise factual details usually elude the interviewee, the passage of time erodes accuracy, and the bias of the person interviewed is difficult to deal with because of his self-consciousness in making "historical record." The principal value of the tapes was the general impressions of the interviewees. Perhaps "oral evidence" is a more exact name for the enterprise than "oral history." I also did not hesitate to write or phone people who could perhaps supply information on particular points. The personal evidence provided by tapes, letters, and conversations contributed greatly to this history.

\section{Printed Works}

\section{California}

California has a rich and well-tilled historical literature. It is best to begin with a sound general history, and Walton Bean's textbook, California, An Interpretive History, 2d ed. (New York, 1973) is excellent and up-to-date. Besides furnishing a succinct overview, its bibliography is a guide to deeper investigation in both the classical histories of the state and the 
extensive monographic literature of the last half-century. Such works provide the broader political, economic, and social context of California's development in which Hastings was set and from which its students came.

For the urban and regional setting of Hastings, three recent works, each different in kind and approach, are particularly valuable. Gunther Barth, Instant Cities: Urbanization and the Rise of San Francisco and Denver (New York, 1975) is a comparative study in urban history revelatory of the peculiar development of San Francisco during the nineteenth century, from founding, through the search for order, the development of culture, and change under the impact of technology. Barth picks up where Roger W. Lotchin, San Francisco, 1846-1856: From Hamlet to City (New York, 1974) left off. Kevin Starr's Americans and the California Dream, 1850-1915 (New York, 1973), the first of two volumes that will recount the intellectual and cultural history of the state, avowedly deals with "the imaginative aspects of California's journey to identity [vii]." It is brilliant and full of suggestion, sometimes perilously seductive, always stimulating. Taken together, Barth, Lotchin, and Starr provide the context for Hastings' urban setting and its early cultural milieu. There is not yet a similar range of recent scholarship of the same high quality for San Francisco and its region in the twentieth century. Walton Bean, Boss Ruef's San Francisco (Berkeley, 1967) enjoys a solitary eminence in revealing graft and corruption at the hands of labor and big business in turn-of-the-century San Francisco-the villain, a graduate of Hastings, a hero, its dean.

The California Historical Quarterly, 56 volumes to date from 1922, seldom failed to provide a volume with an article or note relevant to this study. Institutional history, political history, aspects of economic and legal developments, cultural and educational history, and biographical sketches all figure in its pages.

\section{Legal Developments}

American legal history as a genre of scholarly investigation is still in its infancy. The point of departure for obtaining a grasp of America's legal development is James Willard Hurst, The Growth of American Law: The Law Makers (Boston, 1950). In Lawrence M. Friedman, $A$ History of American Law (New York, 1973), the field finally has a general survey, uneven in places because the secondary literature for so many aspects of American legal history is sparse. A sparkling set of lectures given at Yale by Grant Gilmore, The Ages of American Law (New Haven, 1977) is particulary useful for aspects of law in transition in the twentieth century, especially the Realist-Langdellian controversy.

The nineteenth century is increasingly receiving attention from American legal historians, and this has relevance to the founding of Hastings. Though none of them is directly concerned with California legal development, three recent books are essential to an appreciation of the epoch that produced Serranus Clinton Hastings and his fellow lawyers of early California. James Willard Hurst, Law and the Condition of Freedom in the Nineteenth-Century United States (Madison, 1967) points the direction to understanding the interaction of economic growth and legal change. 
Morton J. Horwitz, The Transformation of American Law, 1780-1860 (Cambridge, Mass., 1977) provides a great deal of insight into this development in the early national period, though his thesis is controversial because it rests upon the notion of an "instrumental conception of law" that might not have been shared by all jurists everywhere throughout the period and leaves unexplained developments in the law that were obviously not "instrumental." Robert M. Cover, Justice Accused: Antislavery and the Judicial Process (New Haven, 1975), with a narrower focus on one area of legal development where there was definitely an instrumental conception of the law at work on the bench, is particularly helpful in understanding the position of John Norton Pomeroy on constitutional law. To measure the impact of Blackstone on American law, its influence on lawyers of Hastings' vintage, the Commentaries must be read in any of the numerous editions; to render that almost intractable work comprehensible, the best guide is Daniel J. Boorstin, The Mysterious Science of the Law: An Essay on Blackstone's Commentaries (Boston, 1958).

California legal history has not been so fortunate. Much of its literature remains in the rather ephemeral stage of articles. Richard R. Powell's Compromises of Conflicting Claims: A Century of California Law, 1760-1860 (Dobbs Ferry, 1977) is a step in the right direction, but it deals with early legal development primarily at the doctrinal level. Four major areas of California legal history in the nineteenth century alone cry out for detailed study of the law in its social, political, and economic context: land-claims settlement, water and mining rights, the impact on the law of populist agitation against the railroads, and California codification. A book on each of these subjects would have been exceptionally helpful to this study of Hastings.

Lawrence M. Friedman, in Contract Law in America: A Social and Economic Case Study (Madison, 1965), affords insight into a major legal development over the course of the nineteenth and twentieth centuries, drawing on the materials available in one jurisdiction, Wisconsin, with applicability beyond its boundaries. This brilliant and provocative book contributes necessary background to the Realist-Langdellian controversy of the 1930s, and provides the starting point for Grant Gilmore's The Death of Contract (Columbus, 1974). The Realist-Langdellian controversy was the spawn of academic legalism, and thus immediately important to what the law schools were attempting to do. Besides the relevant works of Langdell, Keener, and Williston cited in the text and in the notes for Chapter IX, Langdellianism can be appreciated by recourse to a standard text that had a half-century's currency, Eugene Wambaugh, The Study of Cases. A Course of Instruction in Reading and Stating Reported Cases, Composing Head-Notes and Briefs, Criticising and Comparing Authorities, and Compiling Digests (Boston, 1892) chs. I-II, IX-X. A foreign jurist, trained in the Civil Law, attempted to unravel the Langdellian case method at the behest of the ABA; he only partly succeeded but did provide considerable analytical insight into it: Josef Redlich, The Common Law and the Case Method in American University Law Schools, Carnegie Foundation for the Advancement of Teaching Bulletin 8 (New York, 1914). For a judicious but not uniformly profound treatment of the advocate of Realism, the recent study by William Twining, Karl Llewellyn and the Realist Movement (London, 1973), should be consulted 
(one feels sympathy for an English scholar, trained in English law, attempting to comprehend the remarkable influence of legal academics in America). The Llewellyn sorties into the controversy in the 1930s must be followed in the law reviews, but his fully developed theories of law in historical context in its relation to social science are best seen in The Common Law Tradition: Deciding Appeals (Boston, 1960), based upon lectures given at Yale in 1940. If the theories are somewhat mystifying, Richard Danzig, "A Comment on the Jurisprudence of the Uniform Commercial Code," Stanford Law Review, 27 (1975) 621-35 helps in decoding them. As for the UCC itself, Uniform Commercial Code, May 1949 Draft (1949) and American Law Institute: Consideration of Proposed Final Draft of the Uniform Commercial Code, 1950, mimeographed, are of prime importance. The latter, a transcript of the debate, reveals Llewellyn at his rhetorical best. That he could practice the social science that he preached is evident in K.N. Llewellyn and E. Adamson Hoebel, The Cheyenne Way-Conflict and Case Law in Primitive Jurisprudence (Norman, 1941), a legal-anthropological study in which Llewellyn was in yoke with a cultural anthropologist; it is stimulating reading.

\section{Education}

The historical literature on education in America is vast. A useful place to begin is with the concept of liberal education as Hastings and his contemporaries understood it. Besides the works of John Henry Newman, Mark Pattison, and Mark Hopkins, the essence of the Classical tradition can be found in Sheldon Rothblatt, Tradition and Change in English Liberal Education: An Essay in History and Culture (London, 1976). The changing complexion of secondary education paralleling the first three-quarters of a century of Hastings College of the Law and affecting the quality of its entrants is treated in Edward A. Krug, The Shaping of the American High School, 2 vols. (Madison, 1964-72). A lively and contemporary treatment of higher education in California is provided by John R. Thelin, "California and the Colleges," California Historical Quarterly 56 (1977) 140-63 \& 230-49.

The particular role of the University of California in the history of Hastings requires recourse to a number of works devoted to the University. The oldest, by William Carey Jones, Illustrated History of the University of California (Berkeley, 1901) is still useful, written by an intimate of Serranus Clinton Hastings and the founder of Boalt. William Warren Ferrier, Origin and Development of the University of California (Berkeley, 1930) is an accurate and detailed study of the University. UC's centennial in 1968 produced Verne A. Stadtman's The University of California, 1868-1968 (New York, 1970), which does justice to UC's lively past, but which because of its length does not afford the detailed treatment that the archives would allow, and The Centennial Record of the University of California, V.A. Stadtman ed. (Berkeley, 1967), a mine of factual information. Two major crises of the University since World War II are given detailed attention in David P. Gardner, The California Oath Controversy (Berkeley, 1967) and Max Heirich, The Spiral of Conflict: Berkeley 1964 (New York, 1971), the latter on the beginnings of student unrest in the Free Speech Movement. 
Legal education in America has produced a large corpus of law school histories (to which the present work is an addition) and a number of surveys, reports, and many articles on the subject. Legal Education, A Selective Bibliography, Dusan J. Djonovich (Dobbs Ferry, 1970) is the most useful guide into the subject.

Of the histories of particular law schools, Harvard has received the most attention. Charles Warren, History of the Harvard Law School, 3 vols. (New York, 1908) and the Centennial History of the Harvard Law School, 1817-1918 (Cambridge, Mass., 1918) are dated, though still useful. Arthur E. Sutherland's The Law at Harvard: A History of Ideas and Men, 1817-1967 (Cambridge, Mass., 1967) is a splendid study, and particularly useful on Langdell and Ames. A History of the School of Law, Columbia University, Julius Goebel ed. (New York, 1955) is a composite of essays of varying merit, but together they comprise a sound study. Yale is chronicled in four short works by Frederick C. Hicks, Yale Law School (New Haven, 1935-38), from its foundation to 1915. Elizabeth Gaspar Brown, Legal Education at Michigan, 1859-1959 (Ann Arbor, 1959) is a compendium of factual data of , considerable interest but almost impossible density and dryness. The University of Chicago has made a beginning with Frank L. Ellsworth, Law on the Midway: The Founding of the University of Chicago Law School (Chicago, 1977), which deals with the early years and whets the appetite for more. Brief portraits of the law schools in existence about 1890 (including Hastings) are to be found in the Boston lawyers' magazine, The Green Bag, beginning with vol. 1 in 1889 .

The most recent treatment of legal education in America is Robert Stevens, "Two Cheers for 1870: The American Law School," in Perspectives in American History, Donald Fleming \& Bernard Bailyn eds., 5 (Cambridge, Mass., 1971) 403-548. Trenchant, Stevens' study touches all issues relevant to the curriculum development of the schools and the Realist-Langdellian controversy. In the same volume, Jerold S. Auerbach, "Enmity and Amity: Law Teachers and Practitioners, 1900-1922," 548-601, provides another perspective on legal education. For all the merits of these extended essays, the history of legal education in America must start with Alfred Zantzinger Reed, Training for the Public Profession of the Law: Historical Development and Principal Contemporary Problems of Legal Education in the United States, Carnegie Foundation for the Advancement of Teaching Bulletin 15 (New York, 1921). Besides its value as an historical survey of meticulous scholarship, Reed's book was, of course, the manifesto for legal educational reform. The follow-up study, Reed's Present-Day Law Schools in the United States and Canada, Carnegie Foundation for the Advancement of Teaching Bulletin 21 (New York, 1928) and the annual Review of Legal Education in the United States and Canada, compiled by Reed and published by Carnegie, 1913 and 1915-1934, continued by the ABA (Will Shafroth ed.) as the Annual Review of Legal Education, must also be used. More recent works on curriculum reform have value both as primary sources and secondary literature: Albert J. Harno, Legal Education in the United States (San Francisco, 1953) and Training for the Public Professions of the Law: 1971, Report to the AALS (Washington, 1971)—the "Carrington Report." Other materials are cited in Chapter VI, particularly the various publications of the American Bar Association and the Association of American Law Schools. The 
two surveys of legal education in California are [W. Shafroth \& H.C. Horack] Report of the California Survey Committee 1933 and [J.A. McClain, Jr., T.F. McDonald, \& S.P. Simpson] Legal Education and Admissions to the Bar in California (Los Angeles, 1949). The Proceedings of the California Bar Association, beginning in 1910, and the Journal of the State Bar of California, beginning in 1926, round out the sources for the local dimension of legal education. The Journal of Legal Education, 29 vols. (1948 to date) is essential reading for seeing changes in educational ideas and practices during the past three decades.

\section{Hastings}

Previous essays in the history of the College are the Golden Jubilee Book, 1878-1928, Hastings College of the Law of the University of California [San Francisco, 1928] and Edward A. Hogan, "History of the Hastings College of Law," Hastings Law Journal, 4 (1953) 89-100. The latter is of little use; the former is extremely valuable because of the personal recollections of men connected with the College during its first half-century.

Most of the available sources on the Founder, Serranus Clinton Hastings, are cited in the notes to Chapter I. Of particular importance to understanding his motivation in founding and his ideas concerning the College are his two early formal speeches: Address of S.C. Hastings, Founder of Hastings' Law Department of the University of California, before the Regents, President and Faculty (San Francisco, 1878) and Annual Address delivered to the Students of the Law Department of the University of California, August 1879, by S. Clinton Hastings (San Francisco, 1879). A good deal of miscellaneous information about Hastings is to be found in early San Francisco newspapers, in the record of his litigation, and in articles in the California Historical Quarterly. Time did not permit me to make as thorough a search for surviving materials on the Founder as I would have wished; he deserves a study in his own right. Since no corpus of his personal papers appears to have survived, a thoroughgoing biography will be difficult.

Serranus Clinton Hastings and his contemporaries, as well as some of the early graduates of the College, are noticed in Oscar T. Shuck, History of the Bench and Bar in California (Los Angeles, 1901). This collection of antiquarian essays and overblown, short biographical notices is valuable far beyond its demerits. J.C. Bates, History of the Bench and Bar of California (San Francisco, 1912) imitates Shuck in more than title alone, but does additionally provide a great many biographies of lawyers who achieved prominence in the 1890s and 1900s. The early graduates of Hastings are listed in Catalogue of Graduates of Hastings College of the Law, T.A. Perkins ed. (San Francisco, 1897), Directory of Graduates of the University of California, 1864-1916, California Alumni Association (Berkeley, 1916), and William Carey Jones, Illustrated History of the University of California (San Francisco, 1895); the latter also provides a brief career-note on each graduate to ' 94 . Hastings graduates are noticed in The Golden Book of California, Robert Sibley ed. (Berkeley, 1937). Later biographical compilations, particularly Bench and Bar of California, 1937-38 (Chicago, 1937) and Bench and Bar of California: Centennial Edition, 1949 (San Francisco, 1949), are useful. Who's 
Who in America (1897 to date) and Who Was Who in America (1943 to date), the Dictionary of American Biography 22 vols. (1943), Great American Lawyers, 8 vols. William Draper Lewis ed. (Philadelphia, 1907-09), and the Directory of Law Teachers, published almost annually by the AALS since 1922, provide biographical information. The last compilation is especially useful for the 65 Club members. For early women lawyers connected with Hastings, Notable American Women, 1607-1950, Edward T. James, Janet Wilson James, \& Paul S. Boyer eds., 3 vols. (Cambridge, Mass., 1971) and Lelia J. Robinson, "Women Lawyers in the United States," The Green Bag, 2 (1890) 10-32 are helpful. Brief vignettes of Serranus Clinton Hastings and his contemporaries on the state supreme court as well as of successive chief justices (Presidents of the Board of Directors) were done by J. Edward Johnson as a series in the Journal of the State Bar of California, 21-47 (194662). To date, of the Hastings faculty only Dean Taylor has found a biographer: Kenneth M. Johnson, The Life E Times of Edward Robeson Taylor, Physician, Lawyer, Poet, and Politician (San Francisco, 1968).

The Pomeroy System of legal education is revealed in the printed Syllabi, [1880-84]. A number of libraries have these, but the most extensive set (still lacking some courses) is in the College library, the gift of Frank M. Angellotti, '82. Pomeroy's works are treated above in Chapter III. His pedagogical ideas, both as to substance and method, are set forth in The Hastings Law Department of the University of California: Inaugural Address of John Norton Pomeroy, LL.D., August 8, 1878 (San Francisco, 1878). After Pomeroy and until the 1950 s, the curriculum must be reconstructed from the annual Announcement of the College, either in loose form or as incorporated in the annual Register of the University of California. The Announcement lists texts as well as courses throughout the period before faculty records begin in the 1950s. The Announcement also is a principal source for the names and residences, and usually degrees, of students.

Hastings' relationship with the San Francisco bar can be uncovered in The Bar Association of San Francisco: An Illustrated History, J.O. Denny ed. (San Francisco, 1923) and Kenneth M. Johnson, The Bar Association of San Francisco: The First Hundred Years, $1872 / 1972$ (San Francisco, 1972). On the more general matter of the development of the large firm, the sharpest light is cast by Robert T. Swaine, The Cravath Firm and its Predecessors, 1819-1948, 3 vols. (New York, 1946-48), a work of remarkable scholarship by a senior partner of that eminent New York firm, which was the first big law office. Until a similar study is done of a major San Francisco firm, it will be difficult to say exactly how local growth differed from the New York development.

The patent relevance to Hastings of official California publications, particularly the Statutes, the Journal of the Assembly, and the Journal of the Senate, has required continuous recourse to them. Also, the law reports have supplied a great deal of information, some of it directly related to Hastings; this material is cited in the notes to the text.

Newspapers have been used with discretion in this study. The scholar, like the general reader, must treat the press with skepticism. The following San Francisco papers, the Chronicle, the Evening Bulletin, the Examiner, the News-Call Bulletin, and the legal paper, the Recorder, and the Oakland Tribune have furnished useful information. 
The College's own publications, the students' Hastings Law News, the alumni magazine The Hastings Community, and the scholarly journals, particularly the Hastings Law Journal, contain a wealth of information. For the most recent events and developments they are an invaluable source supplementing the more formal records of the College. 


\section{Index}

A

Accounting, 237

Administrative Law, 237, 252, 405

Admiralty, 158, 162, 237, 238, 252, 254

Advanced Property, 68

Agency, 109, 162, 236, 253, 349, 350, 374, 383

Agency and Partnership, 383

Aitken, John R., 174

Alemany, Joseph, 65

Allen, James M., 143, 144, 153

Amandes, Richard, 382

American Bar Association, 194, 204, 205, 211-214, 221, 222, 237, 240-243, 248, 249, 252, 253, 276 , 301-313 passim, 317-320, 329330, 349, 354, 361-364, 373, 392

American Bar Association Journal, 240, 361, 363

American Civil Liberties Union, 281, 297

American Law Institute, 298, 337, 354, 367, 368, 380

American Maritime Cases, 158

American Medical Association, 132, 204, 205, 208, 211

Ames, Alden, 252

Ames, James B., 89, 110, 111, 112, 114,128

Anderson, Andy, 247

Anderson, Marvin J., 382, 386, 398, 412; and administrative structure of Hastings College, 407-409; appointment as dean, 404; curriculum changes under, 399-400, 406

Anderson, Tabytha, 170

Andrews, Alexander B., 240
Angellotti, Frank M., 166, 172, 173, 190, 191, 193

Ashe, R. Porter, 80

Association of American Law

Schools, 150, 153, 192, 213-214, 216, 224, 237, 239, 242, 289, 298, $301,318,320,330,349,350,354$, $361,362,380$

Attorney General v. The Earl of Clarendon, 77

Aviation Law, 359

B

Bade, Edward S., 362

Bailments, 109, 128

Baker, Joseph, 177

Baker, Lawrence, 252

Baker, Lidell, 175

Bakke v. The Regents of the University of California, 402

Balboa Law College, 232, 268, 308, 309

Ballentine, James A., 135, 136, 142 , $159,161,166,170,192,221,226$, 235, 238, 253

Bankruptcy, 237, 244, 252, 254, 374

Barnett, A. T., 174

Barrister's Club, 189

Barry, Joseph E., 174

Bartlett, Louis deF., 127

Basye, Paul, 344, 350, 351

Bates, J. C., 172-173

Beatty, William H., 139, 144, 151

Bell, George L., 159, 16.1, 192

Bell, Golden W., 158, 159, 161, 162 , 238

Benard, Edward G., 252, 253

Bennett, Eugene D., 193 
Bennett, Nathaniel, 32-33, 35-36, 37,38

Bergerot, Peter A., 172

Bergin, T. I., 44, 55, 80, 83, 101, $120,131,138,139,143,144,145$, $151,152,154,155$

Berkeley School of Jurisprudence. See Boalt Hall

Berkley, Thomas L., 282

Berlin, A. Brooks, 189

Bert, Eugene F., 174

Bettencourt, José de Sousa, 176

Bishop, Thomas B., 19, 21, 44, 51, $52,55,80,83,138,139,140,143$, 150

Blackstone, Sir William, 6, 41-42, 64, 96

Boalt, Elizabeth, 118, 151

Boalt Hall, 62, 118, 140-141, 151-153, 155, 178, 216, 218 , 219-221, 225-233 passim, 241; 258, 261, 264-265, 277, 289, 303, $309,324,329,333,340-341$, 346-347, 353

Boalt, John H., 118, 151

Bogert, George C., 262, 320, 337, $348,350,353,360$

Bohemian Club, 136, 216, 298, 323, 333, 343, 380

Boland, James I., 174

Bonté, J. H. C., 85, 126

Borden, Rhodes, 190

Bosley, William B., 127, 128, 156, 191, 201, 203, 222, 241, 244, 300, $301,326,330,331,333$

Boston University, 17

Boyer, Benjamin, 353

Bradford, Abram C., Jr., 13

Bradley, Clark, 331

Bradway, John S., 237, 382, 383

Brann, Walter S., 158

Bray, Absalom F., Jr., 183, 300

Brenner, James E., 319, 364

Britt, E. W., 80

Britton, William E., 347, 350, 357

Britton, William G., 174

Broadcasting and Cable Communications Systems, 359

Brobeck, William I., 172, 186

Brobeck, Phleger and Harrison, 167, 186
Broderick, David C., 117

Brouillet, Arthur W., 189, 314-315, 318

Brown, Edmund G., 341

Bryan, William H., 238

Bryce, Sir James, 116

Buckhout, Emily, 177

Budd, James H., 175

Burns, William J., 180-181

Business Law and Corporations, 374

G

Cabaniss, George H., 190

Calhoun, Benham, 117, 118

California Academy of Sciences, 146

California Appellate Reports, 178

California Bar Association, 221-222

California bar examination, 302-303, 305, 307, 316-317, 320

California Committee of Bar Examiners, 270, 272, 303-304, 307-308, 309-318 passim, 378

California Constitutional Convention, 45-46, 83

California Government, 237

California Law Review, 168

California Reports, 178

California State Bar Association, 191, 221, 222, 303, 310, 312-313, $315,316,317,321,325$

California Western School of Law, 344, 382, 383, 405

Calkins, Jno. U., Jr., 278, 327, 341

Campbell, William W., 216, 217 , 218, 223, 321

Cannon, Horace L., 282

Carnegie Foundation for the Advancement of Teaching, 205-208, 214, 218, 219, 221

Carnegie Institute of Technology, 205

Carpenter, Richard V., 383

Carpentier, H. W., 30

Carriers, 162

Carter, Oliver, 332

Case method. See Langdell/Ames method 
Cathcart, Arthur M., 244, 245, 252, 253, 262, 336, 345, 347

Catherwood, Joseph F., 191

Cerf, Marcel, 190, 238, 239

Chase, Salmon, 88

Cheatham, Elliott, 364

Cheney, Lemuel W., 12, 13

Chicago, University of, 346, 348

Chickering, Allen L., Jr., 191, 326

Civil Procedure, 349, 351, 374, 383

Claremont Colleges, 183, 184

Clark, Alice Ann, 175

Clark, Herbert W., 313, 318

Clifford, Charles H., 189

Code Pleading and Practice, 237, 238, 252

Coffman, Dale, 295

Colby, William E., 182, 193

Commercial Law, 108

Commercial Paper, 350

Common Law Pleading, 162, 252, 293

Comparative Jurisprudence, 85

Comparative Law, 373, 374

Comte, August, Jr., 188

Conflict of Laws, 200, 237

Conflicts, 239, 244, 245, 351, 374

Connolly, Arthur H., 332

Constant v. Ward, 33

Constitutional Law, 105, 118, 158, $160,162,237,238,239,244,245$, $351,374,405$

Consumer Protection, 359

Contracts, 111, 126, 128, 158, 162, 236, 238, 257, 259, 292, 293, 294, $358,369,371,372,373,383$

Cooley, Thomas M., 90, 96, 118

Cooper Medical College, 132, 142, 148

Cope, Walter B., 143, 144, 174, 186, 189

Cope, W. W., 44, 50, 55, 135, 138, $139,143,188$.

Corbin, Arthur L., 214, 366, 371 , 372

Corley, James H., 285, 326, 327, 328

Corporations, 109, 162

Cox, Brooks, 344, 349, 357, 372

Craft, Mabel C., 177, 178

Crane, Judson, 350, 353
Cravath, Paul D., 185

Creditors' Rights and Remedies, 374

Creighton, Charles, 174

Crimes and Criminal Procedure, 373-374

Criminal Law, 105, 111, 126, 128, $162,238,253,348,383$

Crockett, Joseph B., 19-20, 21, 22, 24

Cross, Thomas J., 264

Crotty, Homer D., 310, 311, 313, 314, 317, 349

Cullinan, Eustace, 309-310, 313, 314

Curry, John, 29

Curtis, Stephen, 349

D

Daingerfield, William R., 13, 14, 190

Damages, 374

Davidson, Charles E., 174

Davis, John F., 174

Daw-Kerrell, A., 177

Deasy, Daniel C., 190

Debris Case, 100, 101

de Caprilles, Miguel, 347, 353, 355

Deering, Frank P., 178

Deering, James H., 175-176, 178

DeMonte, Louis, 285-286, 287

Denman, William, 158

Derby, Augustin, 262, 336, 340, 347

Deutsch, Monroe E., 241, 415

Devoto, James A., 172

Dickinson, Edwin D., 242, 246, 324, 325, 326, 353

Domestic Relations, 126, 128, 238, 293, 374

Dorn, M. A., 56

Dumontier, Joseph L., 177

Dunne \& Dunne, 243

Dunne, John J., 174

Dunne, Peter F., 186

Dwight, Theodore T., 90

Dwinelle, John W., 70 
E

Education Policy in the Law, 359

Ehrman, Sidney M., 170, 183, 187, 191, 192, 194, 201, 203, 217, 241, 244, 284, 285, 297, 300, 301, 326, 327,342

Eickhoff, Henry, 188

Eickhoff, Henry, Jr., 193, 194

Eldredge, Laurence, 345, 351

Elementary Law, 128

Elliott, Shelden, 314

Employment Discrimination, 358

Engle, Clair, 249, 280

Environmental Quality Law, 358

Equity, 108, 128, 156, 162, 168, 170, 236, 238, 252

Equity Jurisprudence, 105, 109

Escrichez y Martin, Joaquín, 35

Evans, Charles J., 175

Evans, Oliver P., 44, 55, 57, 75, 76, $78,80,83,85,117,120,138,139$, $140,144,147,150,151$

Evans, Oliver P., Jr., 153, 235, 253

Evidence, 158, 160, 162, 237

\section{F}

Falknor, Judson F., 347

Federal Antitrust, 374

Federal Board for Vocational

Education, 258

Federal Jurisdiction, 351

Ferson, Merton, 353

Field, David D., 92

Field, Stephen J., 70, 91

Fifield, William H., 188

Finch, Serj. Henry, 102

Finlayson, Frank G., 174, 190

Fisher v. Salmon, 37

Fitzpatrick, Timothy, 190

Fleury, Gordon A., 301, 332

Flexner, Abraham, 207-208, 209, 211

Foltz, Clara Shortridge, 47-58 passim, 70, 169, 196, 275, 341, 415

Foltz, Jeremiah, 48
Foltz v. Hoge et al. Directors of

Hastings College of the Law, 50-51, 61, 62, 71, 72, 74, 75, 83, 84, 264

Foote, Henry S., 139, 140, 141, 143

Forrester, William R., 353

Francois, Terry, 282

Frank, Jerome, 365, 366, 372

Fraser, Everett, 262, 320, 329, 337, 350, 353, 360

Frick, Abraham L., 174

Future Interests and Estates, 374, 387

G

General Jurisprudence, 105, 125

George, Henry, 23, 133-134

Gibson, Dunn and Crutcher, 310

Gibson, Phil S., 244, 270, 289, 300, 301,312

Gibson, Richard, 177

Gilmore, Grant, 112, 368

Gladstein, Richard, 297

Glenn, Eugene, 310, 318

Goble, George, 347, 372

Goldberg, Arthur J., 344, 351, 353

Golden Gate (YMCA) Law School, 226, 232, 306, 308, 309, 312, 315

Gonzales v. Huntley \& Forsyth, 34

Goodell, C. J., 253, 371, 372

Goodfellow, W. S., 187

Gordon, Laura De Force, 47, 49-52 passim, 55, 70, 169, 415

Governmental Regulation, 238

Graupner, Adolphus E., 190, 238, 239

Green, Leon, 353

Green, Milton, 347, 351

Gregory, Warren, 222

Griswold, Erwin, 292, 294, 363

Gunter et al. v. Geary et al., 37

$\mathrm{H}$

Haggin, Louis T., 80

Haight, Henry H., 132

Hale, William G., 262, 271, 279,

$314,315,337,353,360$ 
Hammond, William G., 90, 96, 112 , 123,124

Hancock, Moffatt, 345, 347

Handy, J. C., 180

Harno, Albert J., 248, 347, 352, 363, 364, 365

Harris v. Brown, 37

Harris, William B., 363

Harrison, Maurice E., 149, 150, 221, 222, 277, 284, 285, 297, 300, 327; appointment as dean, 166-168, 183, 186, 189; finances in his administration, 193; friendship with W. M. Simmons, 201

Harrison, Ralph C., 83, 120, 139, $144,152,153,155,157,162$

Harrison, Richard C., 159, 192

Harrison, Robert W., 157, 159, 160, $161,166,192,226,235,237,238$, 241, 242, 245, 253, 344, 346, 350, 355

Hart, W. M., 216, 217

Harvard Law School, 17, 64, 65, 89, 263, 283, 292, 298, 337, 346, 347, 370

Harvard method. See Langdell/Ames method

Hastings College: accreditation of, 224, 240-243, 270, 303-321

passim; admission standards, 18 , 51, 54-55, 119-120, 139, 152-153, 268-269; affiliation with UC, 17-18, 43-44, 51-55, 61-62, 66, 69-75, 81-85, 140-141, 150-156, 161-162, 218-221, 245, 264, 277-278, 285, 286, 324-329, 332-334, 341, 408-409, 416-417; alumni association, 168, 193-194, 269, 277, 301, 313-314, 409-410; Associated Students of, 279, 394, 403; and Boalt, 140-141, 151-153, 167, 216, 218-221, 264, 277-278, 321, Also see Boalt Hall; Board of Directors, 44-47, 51-56, 80, 120, 127, 129-130, 137-140, 143-144, 154-156, 191, 203, 223, 239-243, 265, 269-272, 300-301, 337, 357; competition with other law schools, 225-232, 240-243; current curriculum, 358-359; deanship, nature of, 137-138, 353-354; enrollment, 121-123, 193, 200, 247-248, 329-330, 389; federal support for students, 394-395, 401-402; first class of, 12-13; Clara Shortridge Foltz Society, 57, 403; Golden Age of, 166-198 passim; effects of Great Depression at, 232-236; Greek societies at, 195-196, 279-280, 403; legal aid clinics, 237, 382-383; Legal Education Opportunity Program at, 394, 401, 402; library of, 149-150, 234, 288-289, 406; and minority students, 46, 169-171, 282, 394, 396, 401-402; publications of, 278-279, 386, 403; and A. Z. Reed's attacks upon, 215-217, 223; Registrar's duties at, 378-379; sites of, 142, 145-148, 286-289, 385-386, 410; and the S.F. Earthquake, 135, 142, 145; 65,Club of, 245, 246, 262, 299, 301, 335-360 passim, 373-375, 417; scholarships, 258-259, 393-394; special interest clubs, 280-281; and R. G. Sproul, 223-224, 321-328; state support of, 251, 407; student activism at, 393, 395-400, 401, 402, 403; Thurston Society, 279, 355, 403; and UC Regents, 72-76, 81, 147, 150, 284-285, 326-328, 331-332, 341

Hastings College of Advocacy, 410-411

Hastings College of the Law Press, 411

Hastings graduates: and the bar examination, 254, 256, 267, 268-270; as California Superior Court judges, 190; impact on the legal profession, 171-176; and legal publications, 178; as philanthropists, 183; and the San Francisco Bar Association, 187-190

Hastings Law Center Foundation, 410

Hastings Research Services, 411 
Hastings Service Foundation, 411

Hastings, Azalea (née Brodt), 86

Hastings, C. F. Dio, 29, 44, 46, 124, $127,139,143$

Hastings, Charles P., 46

Hastings, Hoyt, 143, 144, 191

Hastings, Lillian (née Knust), 86

Hastings, Robert P., 57, 65, 77, 79, $80,82-83,86,124$

Hastings, Serranus C., 8, 11, 12; and affiliation with University of California, 61-62, 69, 72, 74-75; appointment as dean, 44; as attorney general, 27, 30-32, 39; and Justice Bennett, 36, 38; and the Board of Directors, 66, 67, 75-78; Catholicism of, 65, 414; as Chief Justice California Supreme Court, 27, 32-39; as Chief Justice Iowa Supreme Court, 26; classical training of, 41-42, 62, 63; commencement address of 1878, 14-17 passim; and Justice Crockett, 19; description of, 14, 31-32; endowment payments, 21 , $52,79,81$; family background, 25-26; and Clara Foltz, 70; last years with the College, 85-87; on law and nationality, 15-16; on legal education, 15-17, 62-66; and C. E. Pickett, 21-24; and J. N. Pomeroy, 68; on property law, 34-39 passim; and public lands, 24, 28, 30-31; and UC Regents, 74-75; and Spanish-Mexican law, 28, 35-36; wealth of, 26-30

Haven, Thomas E., 190

Hayne, Robert Y., 139, 143, 149, 150,188

Hearst, Phoebe A., 60

Heller, Ehrman, White, and McAuliffe, 186-187

Heller, Emanuel S., 172, 187

Hellman, Isaias, 193, 200, 201, 235

Hendrikson, William, Jr., 174

Heney, Francis J., 180-183

Hengstler, Louis T., 127, 128, 140, $157-158,159,160,161$

Hennings, Thomas C., 297

Henry, Lyman, 252, 253

Hervey, John G., 318-319, 320
Hitch, Charles J., 409

Hodghead, Beverly L., 189

Hogan, Edward A., Jr., 312, 314 , $319,328,329,379,380,399$

Hoge, Joseph P., 44, 45, 46, 75, 80, $83,135,188$

Hurlbut, John B., 347

Hurst, James Williard, 89, 185

Hutchinson, Joseph, 13

I

Illinois, University of, 346, 347

Indian Tribes and Treaty

Federalism, 359

Industrial Law, 238

Inkersley, Arthur, 177

In Re Students of Hastings College of the Law, 154, 183, 341

Insurance, 108, 109, 238, 374

Intellectual Property Law, 358

International Law, 105, 125, 373, 374

Interstate Commerce Act, 101

Introduction to the Study of the Law, 383

Irwin, William, 11, 21, 48

$J$

Jackson, C. H., 174

Jimenez, Roberto A., 169

Johnson, Hiram, 181

Jones, William C., 62, 118, 140, $141,173,177,178$

Jordan, Paul S., 312

Journal of Legal Education, 361

Jurisprudence, 373, 374

$\mathrm{K}$

Keener, William A., 128, 370

Keith, William, 59, 60, 61

Keith, Mary M. See McHenry, Mary

Kerr, Clark, 155, 289, 322, 332, 333, 408

Kerrigan, Frank H., 293

Kewen, Perrie, 80, 83, 84, 85 
King, Martin Luther, Jr., 394

Kinnane, Charles H., 246

Knapp, E. G., 56

Knight, Goodwin, 296

Kragen, Adrien, 347

\section{L}

Labor Law, 374

Lake, Delos, 44, 51, 55, 75, 76, 77

La Montagne, E. Clinton, 300

Lancaster, Hazel Utz, 196

Land Registration and Titles, 374

Land Use Planning, 359

Langdell/Ames method, 110-112, $114,128,149,157,254,365-366$, 370,418

Langdell, Christopher C., 89, 110 , $111,112,114,370$

Langdon, William H., 180

Lattin, Norman, 350

Law as to Contracts, 104

Law as to Personal Property, 104

Law as to Persons, 104, 126

Law as to Real Property, 104

Law firms, 184-187

Law School Admission Test (LSAT), 388, 404

Law schools: accreditation of, 240 , 304-305, 308-311; admission standards of, 212-215, 304-305, 310-311, 316-317; 1950

comprehensive report for

California on, 306-309; current recruitment for, 390-391; and deans, 353-354; Eastern dominance of, 346; and forced retirement of faculty, 339-340, 343-344; impact of Great

Depression on, 232-235; history of, 5-7, 39-40, 204; new buildings during the '50s, 289;

proliferation of during the '20s, 226-227; and A. Z. Reed, 210-211; and state bar examinations, 302-311 passim; impact of World War II on, 251

Leake, Chauncey D., 344, 345, 351

Le Conte, John, 11, 12, 57, 62, 72, 173
Legal Bibliography, 237, 252, 263

Legal education: and the ABA reformers, 211-214; and the Carnegie Foundation, 207-208, 217; case method in, 40, 110-114 passim, 255; and Catholicism, 65-66; classicism in, 6-7, 41-42, 58-59, 64, 207; contracts and the doctrine of consideration, 371-372; current problemoriented courses, 358-359; differentiation concept, 210-215 passim; diversity in, 364-365; and German influence, 63, 65, 209-211; Also see Langdell/Ames method; and Pomeroy System, 102-116 passim, 124-129, 254-255; positivism, 90, 95, 111, 414; and public interest law, 390-391; realist school, 294, 366-369, 372; A. Z. Reed's reform efforts, 207-225 passim; reformist movement, 360-366; and the 65 Club, 339-341, 344-352 passim; and Roman law, 58-59, 95, 106; and student activism at Hastings, 396-399, 401, 402, 403

Legal Ethics, 105, 126, 236, 418

Legal Research and Writing, 383, 408

Legislation, 374

Lerer, Ben K., 189

Levitt, Albert, 252, 253

Levy, Raymond H., 278

Lewis, William Draper, 212

Lezinsky, George, 175

Lincoln University College of the Law, 226, 309

Lineker $v$. Ayeshford, 33

Llewellyn, Karl N., 365-368, 372

Lockhart, William, 353

Lopez, Thomas F., 169

Lorenzen, Ernest G., 262, 337, 340, 353

Los Angeles Law School, 225, 303

Low, Duncan D., 243, 252, 253

Loyola University, Los Angeles, 232, 234, 251, 267, 303, 309, 314 , 315

Lyons, H. A., 32, 37 
$\mathrm{M}$

McAllister, Hall, 219

McAuliffe, F. M., 187

McBaine, James P., 347

McCaskill, Oliver L., 262, 271, 287, 336, 347, 356

McClain, Joseph A., Jr., 305

McCrea, Henry, 176

McCutchen, Olney, Mannon and Greene, 187

McDonald, Thomas F., 305

McEnerney, Garret, 187, 216, 217

McGeorge School of Law, 227, 234, 308, 325

McGeorge, Verne A., 227

McGilvray, Kenneth G., 313

McGovney, Dudley O., 262, 337, 347

McHenry, Mary, 14, 49, 56, 57-61, $108,109,114,169,177,275$

McKee, S. B., 73, 84

McKinstry, Elisha W., 84, 121, $124-125,126,127,146$

MacLachlan, James A., 348

McMurray, Orrin K., 86, 158, 162 , $165,178,179,191,216,217,221$, 222, 223, 235, 242, 244, 245, 252, 262, 324, 336, 341, 345, 346, 347, 353,355

McPike, Henry C., 113, 120, 166, 174,186

McWilliams, Robert L., 192, 226

Madden, Warren, 345, 350, 351

Madison, Frank D., 186

Magruder, Calvert, 345, 348, 351

Maitland, Frederick W., 93, 99

Major, Daniel S., 26

Mancuso, Edward, 195

Manuel, Wiley W., 282

Margolis, Ben, 280

Marks, Emerson J., 190

Marriage and Divorce, 128

Marshall, Edward C., 83

Marshall, La Fayette C., 174

Martin, George J., 189, 192, 255

Massachusetts Institute of Technology, 206

Master and Hurd, 286, 386

Melvin, Alexander, 190
Mercantile and Commercial Law, 105, 109

Metoyer, Carl B., 282

Michigan, University of, 346

Miller, Frank D., 176

Mogan, Edmund P., 190

Morrison, Alexander F., 12, 13, 183,186

Morrison, May T., 13

Morrison, R. F., 50, 51, 52, 70, 80, 83, 84

Mortgages, 200, 236, 293

Moses, Bernard, 60

Muir, John, 182

Municipal Corporations, 162, 349

Municipal Law, 67, 84

Muscatine, Charles, 397

Myrick, Justice, 83, 84

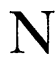

National Center for State Courts, 411

National Committee on State Bar Examiners, 318

National Conference of Commissioners on Uniform State Laws, 367

National Lawyers Guild, 280, 297

National Reporter System, 150

Negotiable Instruments, 109, 236

Negotiable Paper, and Banking and Bills and Notes, 374

Newman, Cardinal, 65-66

New York University Law School, $67,99,100,289,346,347$

Niles, Russell, 347, 353

North, H. H., 174

Nottelmann, Rudolph H., 348

Nutting, Charles B., 289, 290, 353

0

Oakland College of Law, 226

O'Donoghue, M. F., 175

O'Gara, Gerald, 301, 316, 332

Ohio Northern University, 349

Oil and Gas Law, 359 
Okawara, Tom, 169

O'Keefe, James T., 177

Olney, Warren, 188

Olney, Warren, Jr., 127, 128, 156, $187,189,190,191,221,241,258$

Olsson, Juanita M., 255-256, 263

Orrick, Andrew D., 187

Orrick, Herrington, Rowley, and Sutcliffe, 187

Orrick, William H., 187

Osborne, George E., 347, 350, 355

Osborne et al. v. Elliott et al., 33

Owens, Edwin J., 312, 314

Owens, William B., 347

\section{$\mathrm{P}$}

Pacific Coast University, 309

Parker, Frank, 196

Partnership, 108, 374, 383

Patent Law, 374

Patiño, Antenor, Jr., 394

Patterson, Edwin W., 362, 372

Peart, Hartley F., 189

Peixotto, Edgar D., 172

People ex rel. Alexander Campbell v. Clark, 33

People etc. ex rel. S. C. Hastings v. Perrie Kewen, 83

Perkins, Rollin, 348, 350

Personal Property, 126

Persons and Personal Rights, 125

Phipps, William T., 175

Phleger, Herman, 186

Pickering, Harold G., 344

Pickett, Charles E., 21-24

Pigott, John, 382

Pillsbury, Evan S., 185-186

Pillsbury, Horace D., 186

Pillsbury, Madison and Sutro, 185, 186

Pitzer College, 183

Pitzer, Flora A. (née Sanborn), 183-184

Pitzer, Russell K., 183-184

Platt, William H., 16-17, 45, 46, 125,126

Pleading and Practice, 158, 162, 200, 237
Pomeroy, Ann R. (née Carter), 99

Pomeroy, Carter P., 92, 116, 175, 178

Pomeroy, John N., 42, 45, 58, 59, $76,82,88,89,109,116,118,119$, $120,124,146,175,184,261,347$, 370; and equity, 97-99; and S. C. Hastings, 67-69; and legal ethics courses, 126; and municipal law, 94-95; and nationalism, 93-94; positivism of, 90-91; publications of, 91-100 passim; and Railroad Tax Cases, 100-101, 184; and C. W. Slack, 119, 162

Pomeroy System, 102-117, 156, 162, 254, 418

Pound, Roscoe, 292, 343, 371

Powell, Richard R. B., 224, 350

Powers, 108, 109

Powers, Frank H., 187

Practice, 351

Press Law, 374

Primary Rights and Duties, 103, 106

Prince, Eugene M., 300, 301, 313, 314, 319

Pritchett, Henry S., 205, 206-207, 211, 218-219

Private Corporations, 162, 236

Probate, 351, 374

Property, 111, 128, 168, 201, 239, 252, 263, 351, 374, 383

Prosser, William L., 268, 292, 313, $314,318,325,329,330,331,333$, $334,336,347,353,354,355,381$, 382

Public Corporations, 192

Public interest law, 390-391

Public Service Corporations, 162, 200, 237

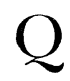

Quasi-Contracts, 126, 128

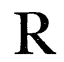

Radin, Max, 262, 296, 337, 340, 347 
Railroad Tax Cases, 100-101, 175, 184

Ramus, Peter, 102

Real Property, 105, 108, 109, 125, 126, 156, 162, 201, 236, 350

Reed, Alfred Z., 207-219 passim, 223, 224, 225, 227, 239, 240, 321 , 363,364

Reeve, Tapping, 6

Regan, Edwin J., 332

Regulation of Public Utilities, 374

Remainders and Executory Devises, 109

Remedial Rights and Duties, 103, 106

Remedies, 105, 351

Restitution, 253, 374

Richards, John W., 348

Richardson, James R., 362

Riesenfeld, Stefan, 347

Rights and Duties Relating to

Things and Transactions as their Object, 103

Riordan, John H., 181, 189

Roberts, Hiawatha T., 282

Roman Law, 58, 62, 68, 95, 105, 118,125

Root, Elihu, 99, 112, 113, 115, 116, 212, 222, 240, 303

Rothwell, Thomas, 382-383

Rouleau, Oscar A., 177

Rowell, Ira, 252, 253

Ruef, Abraham, 134-135, 144, 171, $180,181,418$

Ryan, Edward J., 127, 176

$\mathrm{S}$

Sales, 109, 293, 374

Sales of Private Property, 236

Sammis, Arthur M., 287, 313, 314, $315,318,319,326,327,328,329$, 338, 348, 349, 373, 404, 405, 406 . 409; admissions policy of, 387-388; appointed dean, 387; appointed R. W. Harrison Professor, 380; appointed Registrar, 378-379; curriculum changes under, 382-384; early years of, 377-378; retirement of,
386-387; and D. E. Snodgrass, 376-381; and student activism, 398

Sammis, Eugenia (née Rutherford), 378

Sanborn, Sheffield, 127, 157

San Francisco Bar Association, 19, 21, 44, 45, 66, 135, 143, 187-190, 191, 321, 325

San Francisco Law Library, 17, 45, 148, 149, 150, 172, 175, 196

San Francisco Law School, 226, 238, 268, 293, 308, 309, 315

San Francisco Legal Aid Society, 237, 382

San Francisco State College, 386

San Mateo County v. Southern Pacific Railroad Co., 100

Santa Clara County v. Southern Pacific Railroad Co., 100

Santa Clara University, 226, 227, 232, 234, 251, 267, 309, 312

Sawyer, Lorenzo, 100

Schlessinger, Bertrand, 174

Schmitz, Gene, 134, 135, 144

Scott, Austin W., 156

Seavey, Warren, 263, 279, 348

Selective Service System, 257-258

Shafroth, Will, 214, 363, 364

Sharpstein, J. R., 44, 75, 80

Shattuck, Warren, 348

Sheehan, Wallace, 189

Shepherd, Harold, 372

Sherriffs, Alex, 237

Sherry, Arthur, 347

Shipping Contracts, 108, 109

Shoemaker, Daniel R., 300

Shores, Leander, 177

Shortall, Edward P., 190

Shuck, Oscar T., 171-172

Shurtleff, Charles A., 174, 189, 190, 191, 193, 222

Siebert-Smith, Helen G., 169

Sierra Club, 182

Simes, Lewis, 350

Simmons, William M., 166, 192, 193, 199, 229, 240, 241, 242, 244, 245, 246, 273, 300, 324, 370; and ABA accreditation, 243; appointed dean, 200; relations with Board of Directors, 203-204; 
early years of, 201-202; and A. Z. Reed, 216-217, 223; salary of, 201, 235

Simpson, Sidney P., 305-306

Slack, Charles W., 14, 56, 119, 131, 140, 146, 166, 172, 174, 190, 191, 223, 242, 243, 246, 271, 284; and admission standards, 120-121, 153; and affiliation with UC, 152-153, 155-156; and Board of Directors, 137-139, 143, 144, 203; as acting dean, 118-138 passim, death of, 300-301; and enrollment, 121-123, 228-229; and the library, 149-150, 234, 288-289, 406; and Pomeroy System, 88-89, 113-114, 117-118, 124-126, 128, 370; and S.F. Bar Association, 188; and S.F.

Earthquake, 145

Sloss, Max C., 222

Smith, Edwin D., 175, 178

Snodgrass, David E., 137, 159, 226 , 238, 239, 241, 252, 262, 297, 334, $349,371,373,376,393,399$; and ABA accreditation, 311-321 passim; and admission standards, 268, 272; and affiliation with UC, 332-333; appointment as dean, 244-247; and Case of the 47, 269-272; description of, 293-295; early life of, 291-293;

enrollments under, 259-261; and permanent buildings, 283-289; politics of, 280, 296-298; and Max Radin, 297, 340; and Registrar Sammis, 379; and 65 Club, 299, 338, 340-344, 360, 372; and R. G. Sproul, 323-324, 327-328; and state support, 331-332; and veterans, 264-267, 270, 288; during World War II, 257-259, 263

Southwestern School of Law, 309 Spaeth, Carl, 314

Speiser, Lawrence, 281

Sproul, Robert G., 12, 155, 216 , 223-224, 240, 241, 246, 249, 264, $265,270,277,278,284,289$, $321-324,325,326,327,328,330$, $331,332,333,334,341,417$
Stanford, Leland, 134

Stanford University, 225, 226, 227, 228, 229, 230, 231, 232, 233, 234, $261,266,267,303,309,314,324$, 346,347

Steffen, Roscoe T., 348, 350

Stephens, C. C., 48

Stone, Julius, 345, 352

Stone, Leonard, 127, 142, 146, 176

Stoney, Thomas P., 80

Story, Joseph, 41, 64

Suing the Government, 358

Sullivan, Matthew, 179, 180, 181, 190

Sullivan, Russell N., 319, 347, 351, 353, 362, 364

Suñol et al. v. Hepburn et al., 36

Suretyship, 109, 237, 293

Sutro, Adolph, 146-147

Sutro, Alfred, 186

Sutro, Oscar, 186

Sweasy, Frank R., 150

Swisler, Charles A., 174

Symonds, Myer C., 280

$T$

Taxation, 237, 238, 254

Tax Law, 374

Taylor, Edward R., 164, 176, 245, 315; and affiliation with UC, 153-156; and T. I. Bergin, 144, 154; and Board of Directors, 138-140, 143-144; curriculum changes under, 162-163; appointed dean, 131-132; faculty expansion under, 158-161; and Henry George, 133-135; and Pomeroy System, 156-157;

Registrar's duties of, 142; and S.F. Bar Association, 188; and sites of Hastings College, 146-148; translations by, 133

Taylor, Eunice (née Jeffers), 136

Tefft, Sheldon, 348, 351

Terry, David S., 117

Tevis, Samuel, 176

Texas Southern University School of Law, 363

Thacher, Thomas, 159, 160, 192 
Thornton, Justice, 84

Thurston, Edward S., 253, 262, 279, 336, 348

Todman, Josephine M., 175

Torts, 108, 109, 111, 126, 128, 162, $170,238,279,334,358,373,383$

Traynor, Roger B., 280, 345, 347 , 351,355

Trusts, 162, 192, 236, 238, 293, 374

Trusts and Estates, 383

Trusts and Future Interests, 293

Turner, Francesca, 394

Turner, Frederick J., 182

Tyler, John F., 190

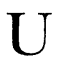

Underwood, Lenore, 342

Uniform Commercial Code, 367, 368

U.S. Bureau of Labor Statistics, 306

U.S. Bureau of Standards, 207

University of California:

Department (School) of

Jurisprudence. See Boalt Hall;

Regents of, See Hastings College, and UC Regents

University of California, Los Angeles, 289, 306, 329, 348

University of Michigan, 173, 346

University of New Mexico, 402

University of Oregon, 344

University of San Diego, 344

University of San Francisco (St.

Ignatius), 179, 226, 227, 232,

$234,246,267,303,312,314,315$

University of Southern California, $173,225,226,230,231,232,267$, $303,308,309,314$

University of Washington, 348

Uses and Trusts, 109

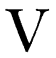

Vanderbilt, Arthur T., 362

Van Dyke, William M., 12, 13

Van Fleet, Alan C., 159, 160

Van Fleet, William C., 143, 144, 153,156
Van Nostrand, John J., 190

Vernier, Chester G., 262, 336, 347

Verrall, Harold E., 348

Veterans' Administration, 257-259, 263-267

Vold, Lawrence, 262, 329, 337, 340, 350

Vrooman, Rachel, 182, 193

W

Walker, George C., 282

Wallace, William T., 44, 67, 73, 75

Wallach, E. Robert, 189, 355

Walsh, Francis P., 252, 253

Warren, Earl, 289, 296, 323

Waste, William H., 165, 190, 191, 240

Wenzlick, William, 176

West Coast Reporter, 92, 175

Wheeler, Benjamin I., 140, 151, 152,155

Wheeler, Charles S., Jr., 149

Wheeler, John T., 176-177

Whitcomb, Frank R., 13

White, Clinton W., 282

White, Jerome B., 187

Whiting, Randolph V., 178, 189

Whittle, Henry D., 176

Wigmore, John W., 193

Williston, Samuel, 128, 292, 293 , $366,370,371,372$

Wills, Testaments and $\$$ Administration, 105, 109, 236

Wilson, Lionel J., 282

Wilson, Samuel M., 44, 45, 46, 55, $83,135,188$

Winans, Joseph W., 72, 73, 80, 83, $85,86,137$

Winans, Joseph W., Jr., 13, 72

Woman Lawyers' Bill, 48, 50

Woodruff v. North Bloomfield Gravel Mining Co. et al., 100

Woodworth v. Fulton et al., 28, 35

Woolsey, Theodore S., 90, 91

Worthington, Leonard A., 300

Wurster, Bernardi and Emmons, 286 


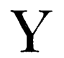

Young, Harry S., 189

Young, Lawrence W., 150
Z

Zabala, Pedro, 169

Zook, Edgar T., 271, 300, 326 